\title{
Illuminated IRanuscrìpts and Iliniatures
}

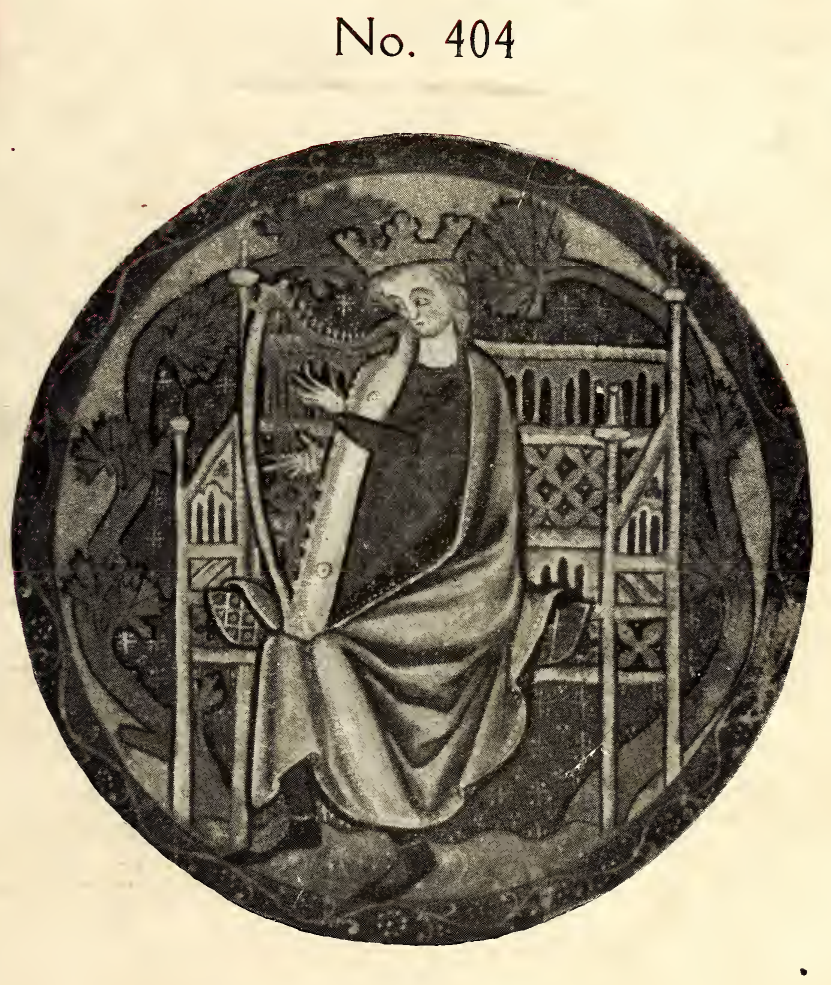

Illagas Bros.

34 \& 35, Conduit Street, I2ew Bond Street, Condon, W. 


\section{List of Contents.}

PAGE

- ANCIENT MANUSCRIPTS (FOREWORD) $\begin{array}{llllllllll}\text { EUROPEAN } & \text { MANUSCRIPTS } & \ldots & \ldots & \ldots & \ldots & \ldots & \ldots & 9\end{array}$ ILLUMINATED MINIATURES FROM EUROPEAN MSS. $\quad \ldots \quad$... 107

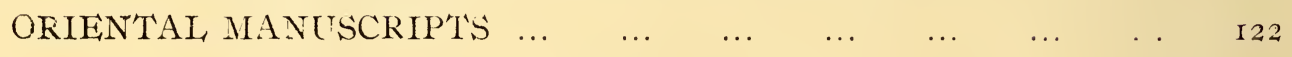
ILLUMINATED MINIATURES FROM ORIENTAL MISS. $\quad \ldots \quad \ldots \quad$ I5I

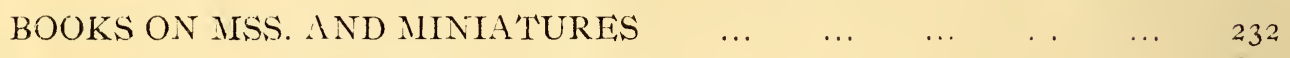
INDICES

$\begin{array}{lllllll}\text { SHORT LIST OF CONTENTS } & \ldots & \ldots & \ldots & \ddots \ldots & 24^{2}\end{array}$ AUTHORS AND TITLES OF EUKOPEAN MSS. $\quad \ldots \quad$... 243 AUTHORS AND TITLES OF ORIENTAL, MSS. . . $\quad \ldots \quad 244$ 
i 
FRON'TISPIECE.

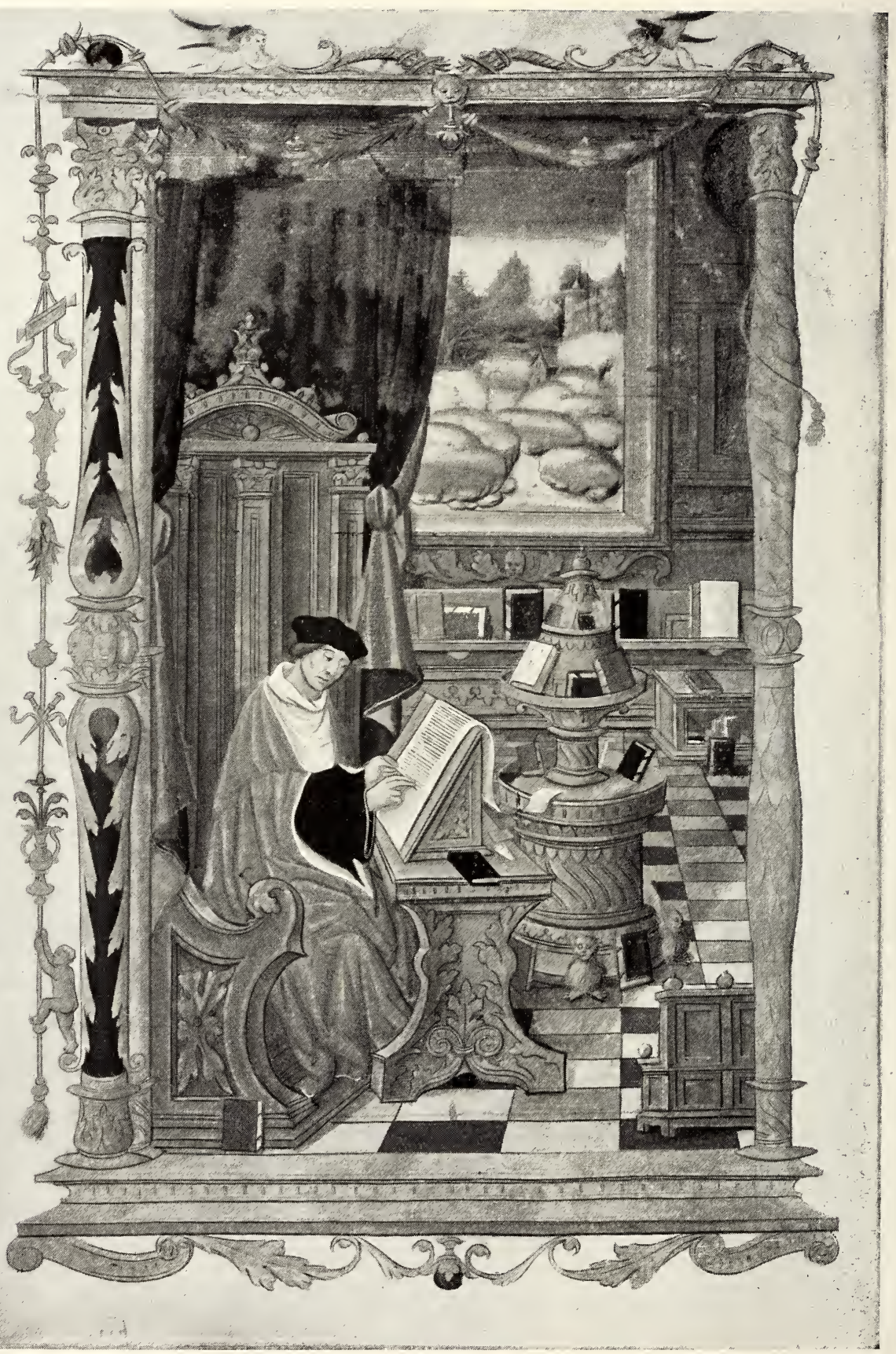

A Miniature from Jerome. Vie, Mort et Miracies.

Illuminated MS. on relium With 5 full-page Miniatures.

Paris, about 1520.

See Item No. 78 . 
No. 404

\title{
Illuminated Manuscripts
}

\author{
and Miniatures
}

EUROPEAN \& ORIENTAL

\section{MAGGS BROS.}

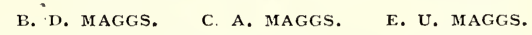

DEALERS IN FINE \& RARE BOOKS, PRINTS \& AUTOGRAPHS

34 \& 35, Conduit Street New Bond Street, London, W.

Telegraphic \&. Cable Address: "Bibliolite, London." Tel.: "Mayfair, 583 I" 
Books can generally be sent on Approval, if desired, subject to all expenses of carriage being paid and decision made within two days of receipt.

\section{SPECIAL ARRANGEMENTS CAN BE MADE FOR SENDING \\ BOOKS ON APPROVAL TO AMERICA AND ABROAD.}

(For List of Current Catalogues, see inside back' cover).

Commissions undertaken at any of the principal Auctions.

(All prices are nett, and do not include carriage.)

All Manuscripts and Miniatures in this Catalogue enter the United States of America free of Duty. 


\section{Ancient Manuscripts.}

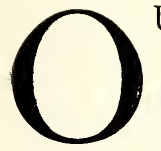

UR classical authors came near being entirely lost to us. Of some nothing has been preserved; of others we possess only fragments, and chance, that blind arbiter of the works of genius, has preserved, in their entirety, some productions of a secondary value. We lost a great number of ancient authors in the conquest of Egypt by the Saracens, which deprived Europe of the use of papyrus. In the absence of papyrus, parchment was employed, which, from year to year, became more scarce and costly. Then the sheets upon which were transcribed classical compositions of Roman or other literature, were cleaned from the writings, as far as possible, and re-used for converting into psalters, breviaries, etc., such was the case with a book of Livy half-effaced which became a Bible, and the orations of Cicero "de Republica" a history of a Monastery.

Such manuscripts are styled "palimpsest." The writers of these "Codices palimpsesti" resorted to several expedients to remove the original writing. Sometimes they would erase the characters, at other times they would remore 
them by chemicals. This practice became so general that severe measures were adopted in Europe to prevent its continuance.

There was a time when a considerable domain was exchanged for a Manuscript; when this acquisition was deemed of sufficient importance to be registered in the Public Acts. All powerful and absolute as was Louis XI., he was not able to borrow the manuscript of Arab Rhasis, for the purpose of making a copy, without depositing Ioo crowns of gold with the library of the Faculté de Paris, and for the completion of this sum the secretary of the Treasury sold a part of the silver plate. For the loan of a volume in I4.7I, a baron offered a security of ten marks in silver, which was considered insufficient. Previously a Countess of Anjou had given, for a book of Homélius, two hundred sheep and a supply of barley and wheat. At this period manuscripts were an object of considerable commerce, the usurers receiving them in pledge as a precious commodity. A student of Paris, reduced to the last extremity, regained his fortune by borrowing money on a book of Jurisprudence, and a grammarian, ruined by fire, rebuilt his house by the sale of two volumes of " Cicers."

Upon the restoration of letters, the savants searched with ardour for these treasures of the past. The passion entailed long journeys, and in the pursuit many fortunes were sacrificed. The acquisition of a province afforded no greater source of congratulation than the finding of an unknown manuscript. "Oh, marvellous fortune!" wrote Aretino to Paggio, upon learning that Poggio had discovered a copy of Quintilian. "I pray you to send me this manuscript at the earliest moment, lest I should die without beholding it."

In this fever of enthusiasm, the savants were tormented by the demon of jealousy when they learned that one of their number was the fortunate possessor 
of a particularly choice work; for, then, the honour of possessing a volume of Cicero almost equalled the honour of composing it.

The Emperor Tacitus caused to be deposited in all the libraries of his Empire copies of the work of his illustrious ancestor, and ordered ten new copies to be made each year, but even this precaution was unavailing; and all the libraries of the Roman Empire seem to have been wholly destroyed. One cop $y^{\prime}$ of Tacitus, however, did escape, and was found in modern times in a monastery of Westphalia.

Illuminated Manuscripts are in many senses the most important, as they are commercially the most valuable. Illuminated Manuscripts are naturally an elaboration on the bare-written volume. The transition from the severely plain to the splendidly elaborate was a gradual one of several centuries. The mediaeval period begins in Ireland in the seventh century and on the Continent in the eighth century, where we find ornaments and designs independent of Roman style. The best period is from I 250 to I 550 . The finest examples of illumination are to be found in the fifteenth century in France, Italy, England and the Netherlands, though some prefer the costly, magnificent and florid ornamentation of the first quarter of the sixteenth century.

(From the Essay which appeared in L'Imprimerie some thirty years since and Madan's Books in Manuscript). 


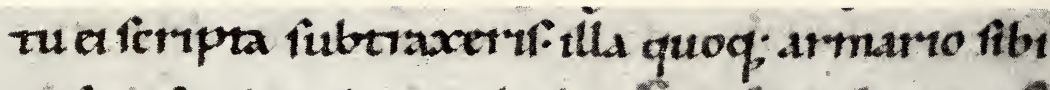
pottea fervenda concludat. Expt. 1 lo g vS.

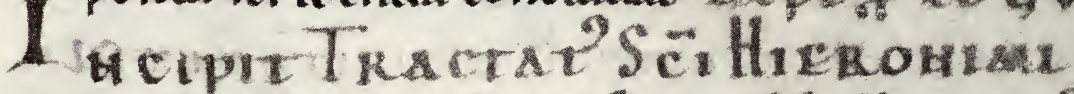

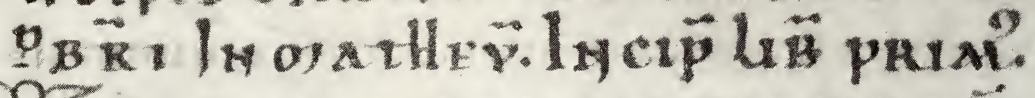

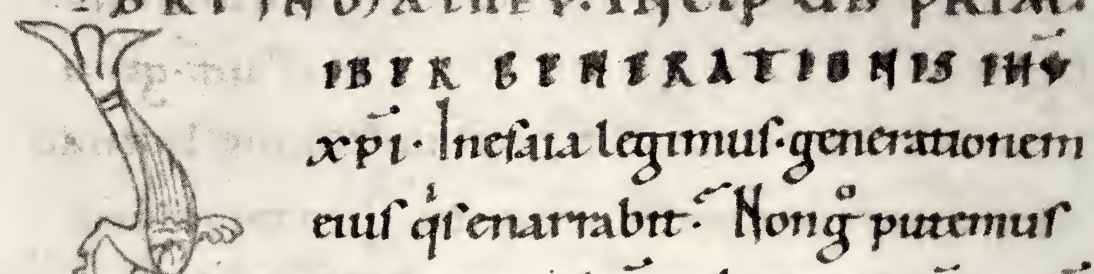
2. 3 uta ơlle

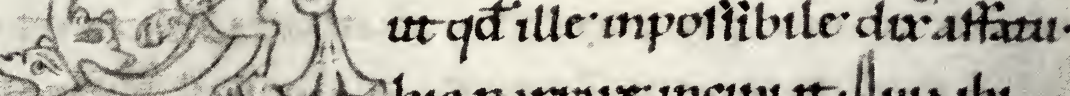

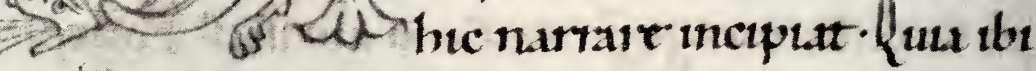
de generattone duuntatal bie de incirmanonir

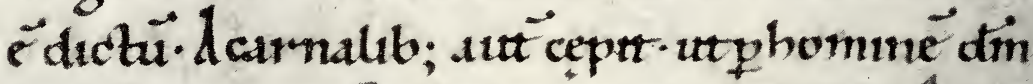

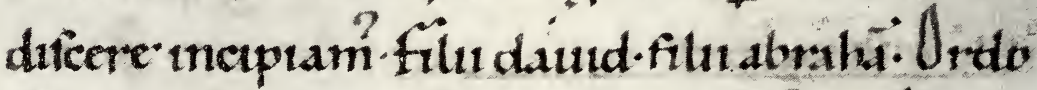

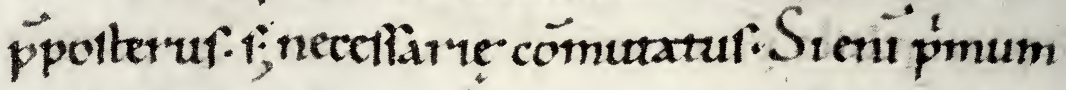

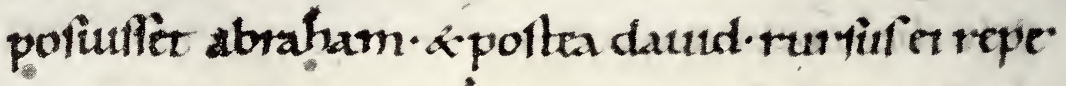

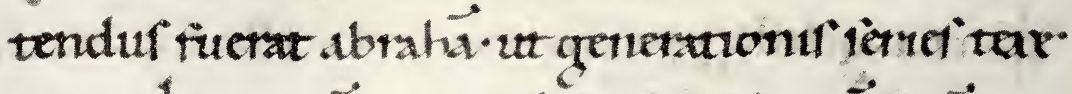

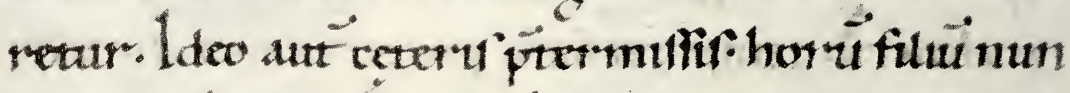

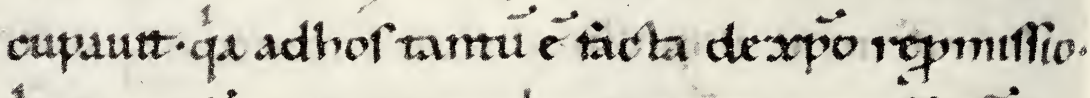
Adabraha- infemme inqu tro-benedicent on i

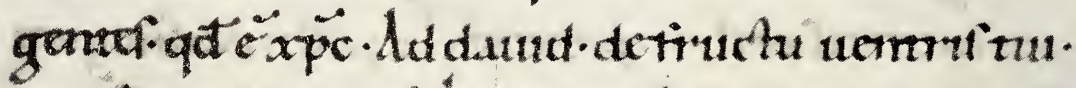

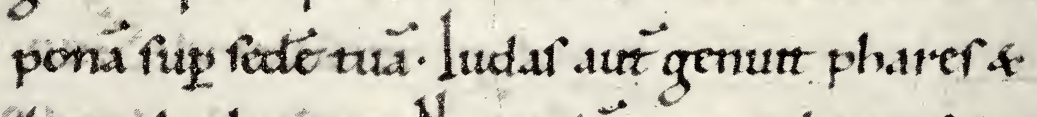
Hara dethamas. Notand ü ingenealogya falua. 


\section{PART I. \\ European Manuscripts.}

Eleventh-Twelfth Century Manuscript.

I JEROME (Saint).

Tractatus in Matthaeum.

MANUSCRIPT ON I72 LEAVES OF STOUT VELLUM, XI.-XII. CENTURY (9 by $6 \frac{1}{4}$ INCHES). FINELY WRITTEN BY A GERMȦ SCRIBE IN SEMI-ROMAN LETTERS, 24 LONG LINES TO A FULL PAGE, GREEK QUO'TATIONS IN GREEK, PAINTED INITIAL TO EACH BOOK.

Thick small 4to, thick boarded crimson morocco extra, inside dentelles, by R. De Coverley, in fine state.

(Bamberg, XI.-XIIth Century).

(See Illustration, Plate No. I.).

$£ 63$

** AN IMPORTANT CODEX. The Scribe Bertolfus has written his name in an inscription at end: "Indignus alummus Sancte Marie NOMINE BERTOLECS mo(nachus) scripsit hunc Codicem optans a domino per hoc reniam pecaminum suorum."

On the last page there is a letter from an unnamed "Babbgensis. eccle. humil. minister," (evidently from his tone of authority, the Bishop of Bamberg) to " B. Geng. Abbati," in which he refers to his own condition of bondage (servitum), and while he asks for his prayers, orders him not to think "de monte commutando." This is written in the same hand as the rest of the book.

Eleventh Century Manuscript from the Augustine Monastery OF REBDORF.

\section{IA FESTIVALE ET DOMINICALE.}

MANUSCRIPT ON VELLUM (I34 LEAVES) WRITTEN IN GOTHIC LET'TERS BY A GERMAN SCRIBE (XI.-XIIth CEN'TURY), 33 LONG LINES TO A FULL PAGE. LARGE SPIRAL INITIAL A IN RED ON THE FIRS'T PAGE OF TEXT.

Folio, old binding of oak boards and leather stamped with diagonal lines, remains of metal clasps.

(Germany, XI.-XIIth Century).

(See Illustration, Plate No. II.).

Inscription on end leaf "Iste Liber est Monasterii sci Johannis Baptiste im Rebdorff, Eystetensis dyocensis." Nearly all other Rebdorff MSS. are in the State Library at Munich where they came at the dissolution of the Monasteries. 
Twelfth Century Medical Manuscript.

\title{
2 MEDICINA TRAGTATUS VARII.
}

\author{
LATIN MANUSCRIP'T (BY AN ENGLISH SCRIBE) ON VELLUM, \\ WRITTEN IN CAROLINE CHARACTERS, BY THREE OR FOUR \\ HANDS, EXECU'TED IN ENGLAND IN THE FIRST HALF OF THE

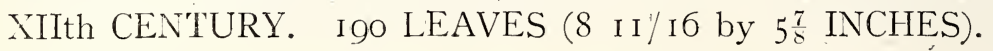

4to, Oid Engiish binding in marbled calf.

Saec. XII.

$£ 155$

* * A MANUSCRIPT OF THE HIGHEST IMPORTANCE TO THE STUDENT OF THE HISTORY OF MEDICINE.

It contains upwards of 26 treatises on medicine, as follows: A treatise on plasters; Extracts or notes on the Hellebore, the bite of the mad dog, etc.; A short list of cataplasms, plasters, syrups, antidotes, and Galenus de morsu rabidi canis.

Directions for a three days' fast, followed by prayers to obtain certain graces, and by the Sortes 1 postolice; a short list of lotions and unguents; Prologus et commentum Alexandri super Aphorismos Hippocratis (leaves 14-78); Liber Alexandri (a list of medicaments and cures for various ailments, probably by Alexander Trallianus, and with contemporary interesting margina! notes by a different hand), leaves 78-95; Ratio ponderum vel mensurarum dicersarum medicinarum.

Medical receipts for various ailments; Oratio ad dispensandam medicinam; Galeni de pulsu et urinis, et Proguostica (leaves 101-3); ORIBASII DE HERBALUM VIRTUTIBUS (leaves 103-20); Dynamedia Hippocratis (leaves 121-28); De passionibus singulis (an enumeration of various maladies with a list of potions); De signis ponderum secundum graecos (leaf 130); Liber Oribasii ad Eustadium filium sum (leaves 131-40); Liber Oribasii ad Eunapium Euporistam (leaves 140-146).

Two letters of Hippocrates to his Necenas and to King Antigonus; Ratio sphaerae Pythagorae philosophi, quam Apollonius descripsit, de egris, sive vita sive moris eis futura fuerit, ets. (Leal 148); Liber Constantini de cirurgiis (leaves 149-59); ALPHABETUII HERBARUM GRAECE E'T LATINE (leaves 161-68); EPISTOLA GALIENT IN ANTIBALLOMENON FOLLOWED BY THE LIST OF MEDICINES AND HERBS WITH 'THEIR SUBSTTTUTES (leaves 168-9); A HERBARY FROM GALEN AND O'THERS; Philaretus de pulsibus (leaves 177-79); Curatio Elephantiosorum (leaf 179); Prognostica Hippocratis (leaves 180-85), etc. The last 5 leaves contain an account of three miracles operated by the Virgin; and the first line of the hymn Are Mari Stella, the Venite exultemus, the Christmas hymn Laudes Deo dicam, and the Sanctus, all with musical notation by neums.

It is of great interest to note that the date of the manuscript can be assigned pretty accurately between the year's 1100 and 1150 ; for on the verso of leaf 148 is given a list of Popes beginning with Alexander II. and ending with Eugenius III. (1061-1153). But the note referring to Eugenius III. (1145-53) is in different ink and hand, thus showing it had been added by another person and at a somewhat later date, while all the previous ones are by the sante hand. 


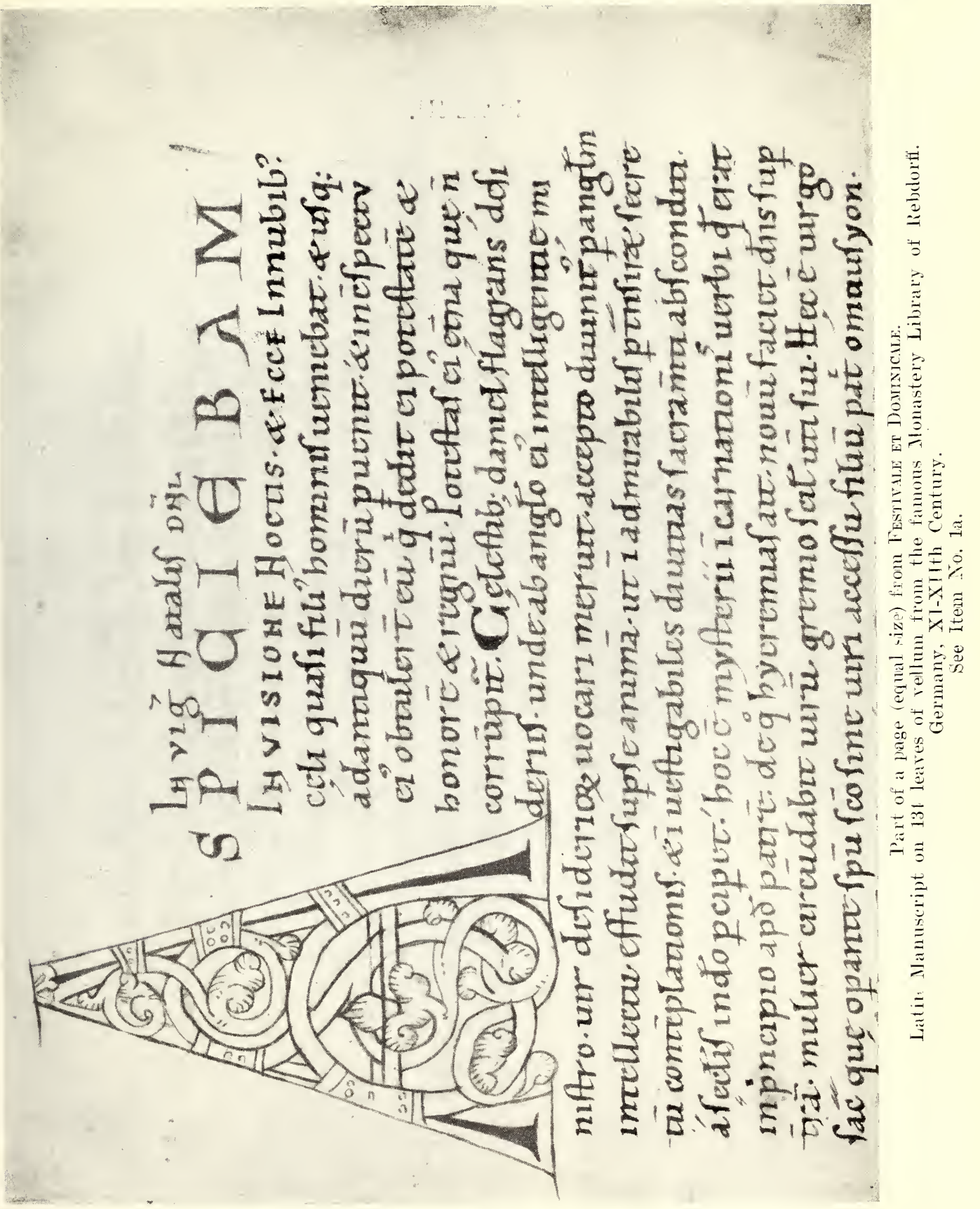


Plate 111.

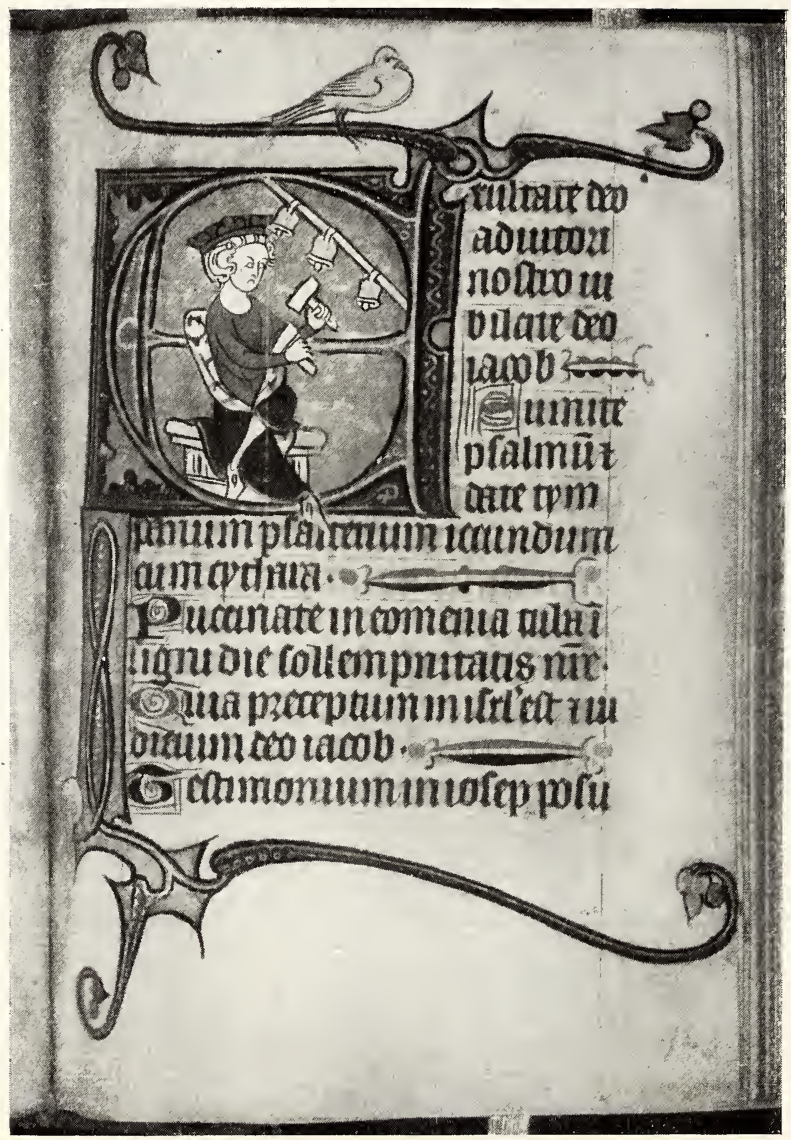

A page (equal size) from Psaltericm Latinum. Illuminated Psalter on vellum written by a French scribe. With 8 Miniatures.

- France, XIIIth Century.

See Item Ño. 5 . 
MAGGS BROS., 34 \& 35, Conduit Street, London, W.

'I'welfth Century Manuscript from the Augustine Monastery of REBDORF.

2A AUGustine (Saint).

Sermones de Sanctis Augustino, Ambrosio et Hieronymo.

LATIN MANUSCRIPT OF THE TWELFTH CENTURY BEAUTI-

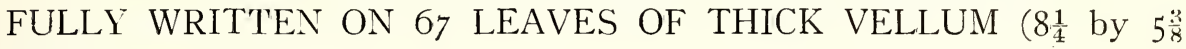
INCHES).

Extracts from Homilies on the Godly Life by Early Church Fathers (in Latin), written on 94 leaves of vellum by another hand in the XIIth Century.

8vo, bound together in an old Momastic binding (XIVth century) of oak boards covered with stamped pigskin, with brass clasp, the covers lined with portions of a notated service book and other MS. leaves of an early date (last leaf of sermones supplied by a later hand).

(Germany, XIIth Century.)

f52 10s

MSS. from the famous Library of the Augustine Monastery of Rebdorf are very rare, as nearly all the MSS. are now in the State Library at Munich.

Twelfth Century Manuscript.

3 PRUdentius (Aurelius).

CATHEMERINON; PERISTIEPHANON; APO'THEOSIS; AMARTYGENIA; PSICOMACHIA; CONTRA SYMMACHUM LIBRI DUO; OPUSCULA; PHYSIOLOGUS.

VERY FINE MANUSCRIP'T OF 'THE TWELFTH CENTURY, BEAUTIFULLY WRITTEN ON STOUT VELLUM, WITH LARGE ORNAMENTAL CAPITALS IN RED AND GREEN, TITLES RUBRICATED, IN FINE PRESERVATION.

Small folio, calf, gilt back.

(XIIth Century.)

$£ 65$

** Very rarely are manuscripts to be found containing so many Works of this author. Sanderus in his "Bibl. Belgica" mentions this identical MS. It formerly belonged to a Belgian monastery, and bears on the first page the following benediction and nalediction, "Liber Sancte [Marie Bonae Spei] servanti benedictio: Tollenti maledictio fiat. Amen." 
Magnificently Illuminated in the Thirteenth Century.

4 PSALTERIUM LATINUM, cum Kalendario.

SUPERBLY ILLUMINATED MANUSCRIPT IN SURPRISINGLY FRESH AND CLEAN CONDITION ON 2I 8 LEAVES OF THICK VELLUM ( $6 \frac{1}{4}$ by $4 \frac{1}{2}$ INCHES), WRITTEN BY A FLEMISH SCRIBE IN 'THE NOR'TH OF FRANCE ABOU'T 'THE YEAR I 287.

BEAUTIFULLY WRITTEN IN LARGE AND CLEAR GOTHIC LETTERS, I9 LONG LINES TO A FULL PAGE. THE CALENDAR IS WRI'ITEN IN RED AND BLACK WITH DECORATIVE INITIAL LETTERS IN BURNISHED GOLD, ORNAMENTAL BORDERS OF RED, GOLD AND BLUE, AND ALSO TWELVE VERY LARGE MINIATURES IN BRIGHT COLOURS ON A BACKGROUND OF BURNISHED GOLD, ILLUS'TRATIVE OF THE OCCUPATIONS OF THE TWELVE MONTHS OF THE YEAR. THESE MINIATURES ARE OF EXCEPTIONAL SIZE (AVERAGING 5 by 2 INCHES) AND QUALITY, AND WE KNOW OF NO MANUSCRIPT WITH SUCH A FINE SUITE OF CALENDAR MINIATURES.

THERE ARE FURTHER I 5 LARGE FULL-PAGE MINIATLRES WITH SUPERB BURNISHED GOLD BACKGROUNDS MAGNIFICEN'TLY EXECUTED BY A GREAT MASTER OF XIIIth CENTURY ILLUMINATION AND 8 VERY FINE SMALL MINIATURES. WITH 2 I 8 FINE BORDERS (ONE TO EVERY PAGE) CONSISTING OF BLUE AND GOLD ORNAMENTAL WORK WITH OCCASIONAL GROTESQUE HEADS IN RED.

ALSO HUNDREDS OF LARGE AND SMALL INITIAL LETTERS IN BURNISHED GOLD AND FINE TEXTUAL DECORATION IN BURNISHED GOLD AND COLOURS.

8vo, Old French red floreate silk, g.e.

(North of France. About A.D. I287).

(See Illustrations, Plates Nos. IV. and V.).

$£ 4,750$

A MOST MAGNIFICEN'T EXAMPLE OF THE BEST STYLE OE MEDIATAL ILLU MINATION OF THE FINEST NOI'TH OF FRANCE SCHOOL, ABOUT 128̈, IN UNRIVALLED CLEAN CONDITION. THE CONDITION OF THE MANUSCRIP'T, MINIATURES AND BORDERS IS EXCEP'TIONAL, AND IT IS AMAZING THAT A MANUSCRIP'I OF THE THIR'TEENTH CENTURY SHOULD HAVE BEEN PRESERVED TO OUR DAYS IN SUCH A FINE STATE.

The miniatures are beautifully executed and are painted invariably over a layer of thick burnished gold, which is also used for the backgrounds. The miniatures represent :-

The Calendar.

1. (January) A man seated before the fire, warming his bare leg and drinking.

2. (February) Woman with Candlemas taper.

(Continued over) 


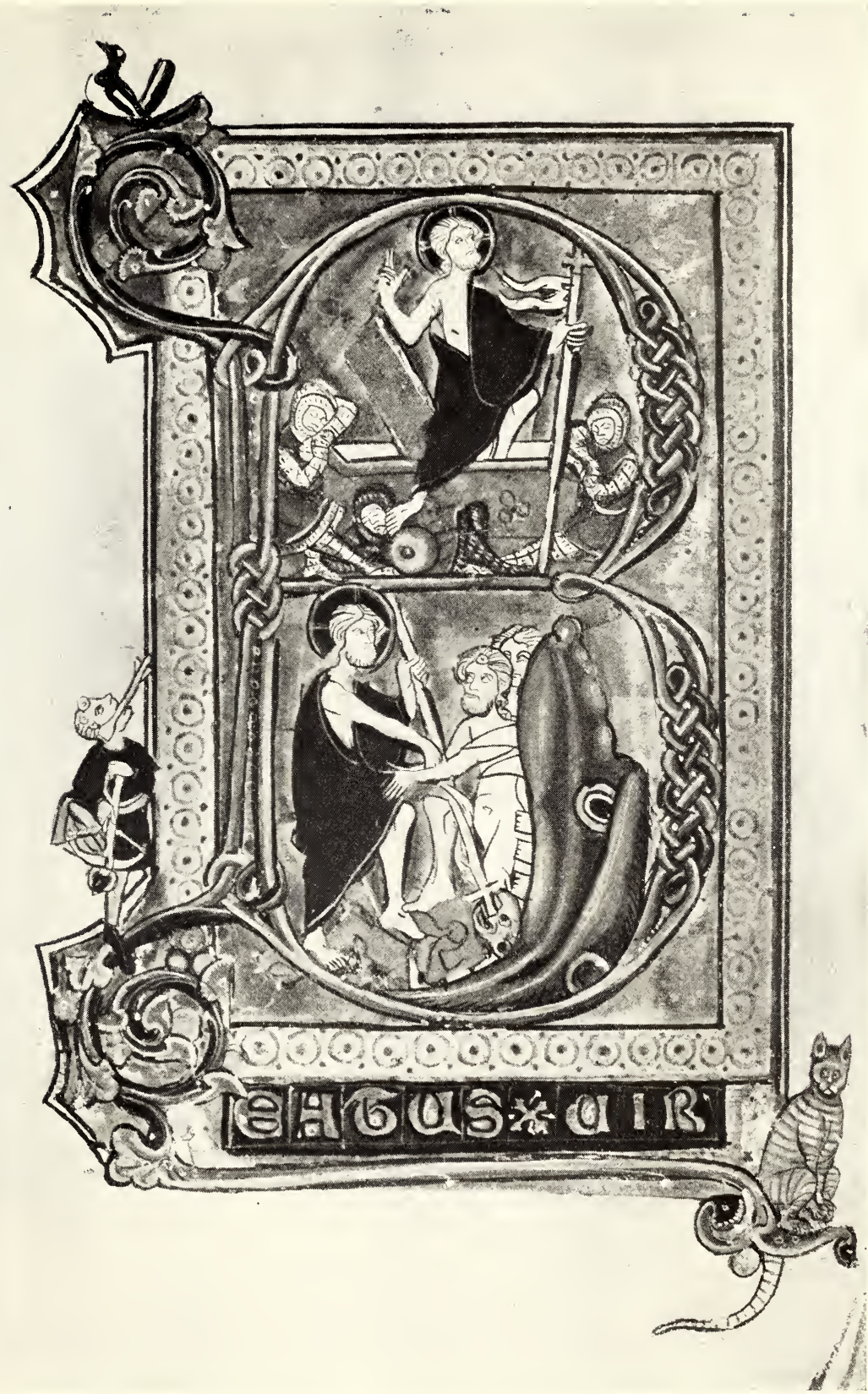

A page (equal size) from Psalterium Latinum cum halendario.

Magnificent P'salter on vellum with 12 Calendar miniatures, 15 large and 8 smail miniatures on burnished gold ground.

Flanders about 1.D. 1287.

See Item No. 4. 


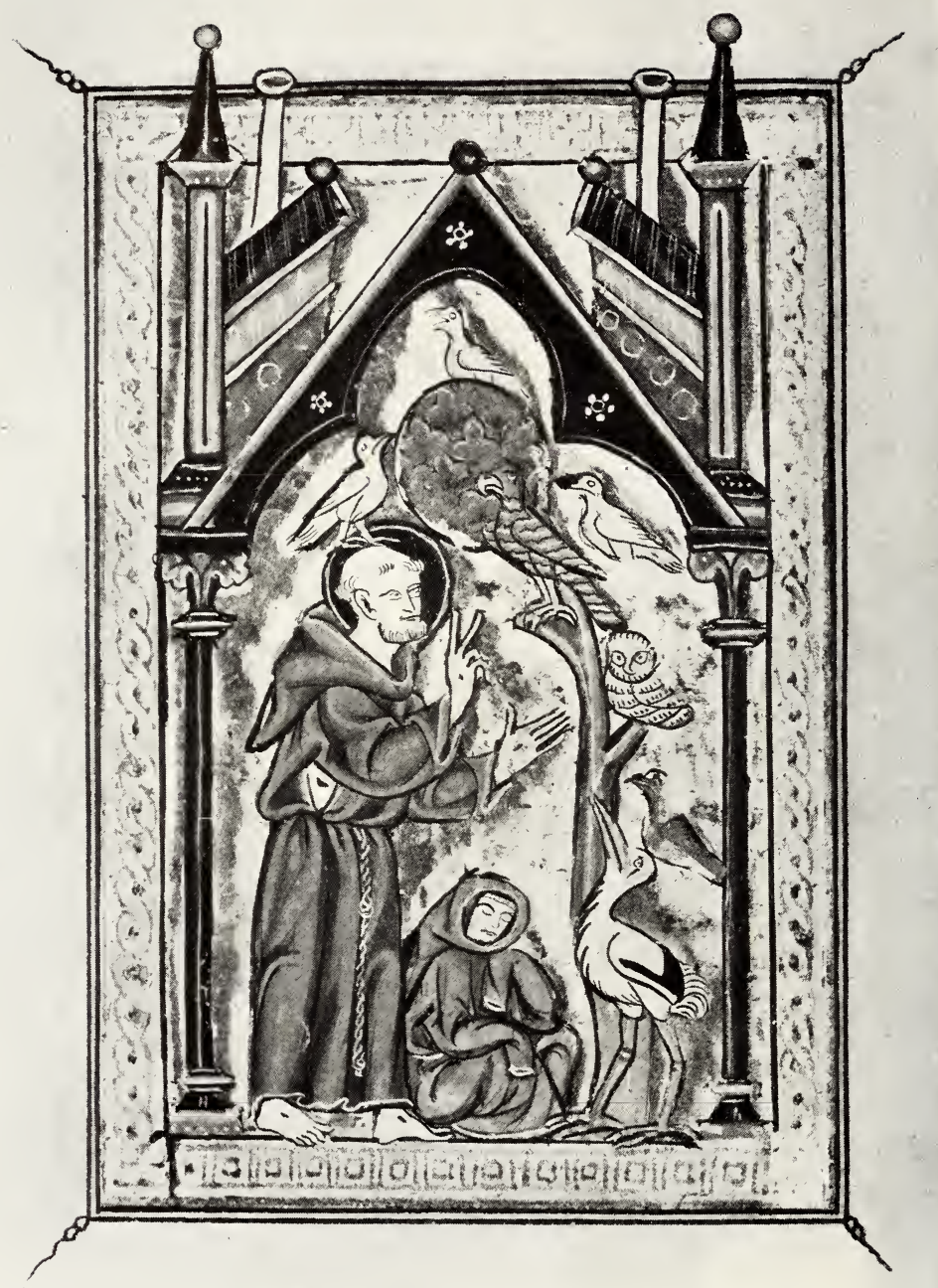

Ear liest known representation of St. Fraxcis of Assissi preaching to the birds. A page (equal size) from Psalteriua Latinda cum Kalendario.

Magnificent Psalter on vellum with 12 Calendar miniatures, 15 large and 8 small miniatures all on burnished gold ground.

Flanders about A.D. 1287.

Se? Item No. 4. 


\section{Psalterium Latinum-continued.}

3. (March) A man pollarding a willow-tree.

4. (April) A Youth holding flowers.

5. (May) A Lady and Gentleman riding pillion on horseback, hawking.

6. (June) A man carrying branches.

7. (July) A countryman with his scythe cutting grass.

8. (August) A man cutting standing corn, and a woman binding it into bundles.

9. (September) Plucking grapes and treading grapes for wine.

10. (October) A man sowing.

11. (November) A man killing pigs.

12. (December) A butcher killing an ox.

The other Miniatures represent:-

1. The Annunciation.

2. The Nativity.

3. The Adoration of the Magi.

4. The Flight into Egypt.

5. The Baptism of Jesus in Jordan by St. John the Baptist.

6. The Flagellation.

7. The Crucifixion, surrounded by a border composed of 16 squares alternately blue and red, each containing one of the Old 'Testament Prophets, each witl forefinger of right hand pointing to Jesus on Cross, as culmination of Prophecy.

8. The Resurrection above, and below The Last Judgment, the whole forming the letter "B."

9. Saint Peter with the Key (small miniature).

10. Jesus and Mary Magdalen.

11. Jesus appearing to Saint Thomas.

12. Saint Paul with the Sword, the fox at the corner of the border is biting off the rabbit's ear, whom he was going to teach to read the Psalter (small miniature). (Legend of Reynard, the Fox).

13. St. Laurence on the grill being prodded with a pitchfork (small miniature).

14. The Ascension.

15. St. Stephen being stoned to death (small miniature).

16. The Descent of the Holy Ghost.

17. St. Margaret with the Dragon (small miniature).

18. St. Dominic preaching to an audience of men and wowen.

19. Saint Nicholas (small miniature). A juggler (at foot of page) is balancing a long box on his nose.

20. St. Francis of Assissi preaching to the birds. This is the first known representation of this scene.

21. Saint Martin dividing his cloak with a beggar (small miniature). At side of page, a juggler balancing a long wooden pole, on the top of which is a saucer on which is sitting a large squirrel with fine brown tail eating a green nut.

22. The Coronation of the Virgin (small miniature). At foot of page is a large monkey eating fruit.

23. The Resurrection, with two angels holding the emblems of the Passion.

OF GREAT INTEREST ARE THE CLEVERLY PAINTED NUMEROUS GRO'TESQUES AT FOO'T OF PAGES, SUCH AS PARROT, OWL, MONKEY, FOX AND RABBIT, DOG, JUGGLERS, CAT, ETC., WHICH ARE MOST UNUSUAL AT THIS EARLY DATE. 
5 PSALTERIUM cum orationibus, litaniis sanctorum, etc.

MS. WRITTEN BY A FRENCH SCRIBE ON 288 LEAVES OF VELLUM, IN LATIN, WITH NUMEROUS INITIAL LETTERS PAINTED IN BLUE AND RED, AND O'THER ORNAMENT'TTIONS. TOGETHER WITH 8 MINIATURES, CONSISTING OF INITIAL LETTERS ELONGATED AND ADORNED WITH GROTESQUES, DOGS, BIRDS, LIONS, FOOLS, RABBITS, MONKEYS, SINGING BIRDS, TOUCANS, AND OTHER WEIRD CREATURES OF THE MEDIAEVAL ARTIST'S IMAGINATION.

THE MINIATURES ATTAIN A VERY HIGH LEVEL OF XIIIth CENTURY FRENCH ART.

I2mo, calf antique.

(France, XIIIth Century).

(See Illustration, Plate No. III.).

The Miniatures consist of :-

(1) Three Cleries singing before the lectern.

(2) The revelation from Heaven.

(3) King David praying.

(4) Temptation by Satan.

(j) The fool says in his folly "'There is no God."

(6) Save me, oh, Lord!

(7) King David arrayed in a b!ue cloak playing the bells, and carrier pigeon above, illustrative of the rerse: "Exult in the Lord Who is our help, give glory to the God of Jacob."

(8) The Lord said to My Lord, " Sit on my right hand."

*** These Miniatures are all on burnished gold backgrounds.

\section{A LE BRUT, or Chronicle of England.}

FRENCH MANUSCRIPT WRITTEN ON VELLUM BY AN ENGLISH SCRIBE OF THE FOUR'TEEN'TH CEN'TURY. LONG LINES.

4.to, calf.

(England, XIVth Century).

Although labelled at back Tiringham's Chronicle, this manuscript is a Erench version of Le Brut similar to that in the British Museum. The first part corresponds closely to the English version of the Brut published in 1906 by the Early English Text Society, but the narrative is much condensed in the latter part which is written in a different hand. Our manuscript however contains details relating to Richard I.'s Crusade to the Holy Land and the Scotch Laws of Edward III.'s reign not mentioned in the English version.

'The Chronicle begins with the legendary account of the Advent of Brutus, son of Aeneas, to England. “En la noble cité de graunt Troie." It contains other legendary matter on the early Kings of England, including King Arthur, and ends with the sack of Haddington Fair in 1333.

On the blank sicle of the last fly leaf there is a note in a Fifteenth Century Scotch hand of the marriages of English Kings from Henry I. to Richard II. 


\section{PLATE VI.}

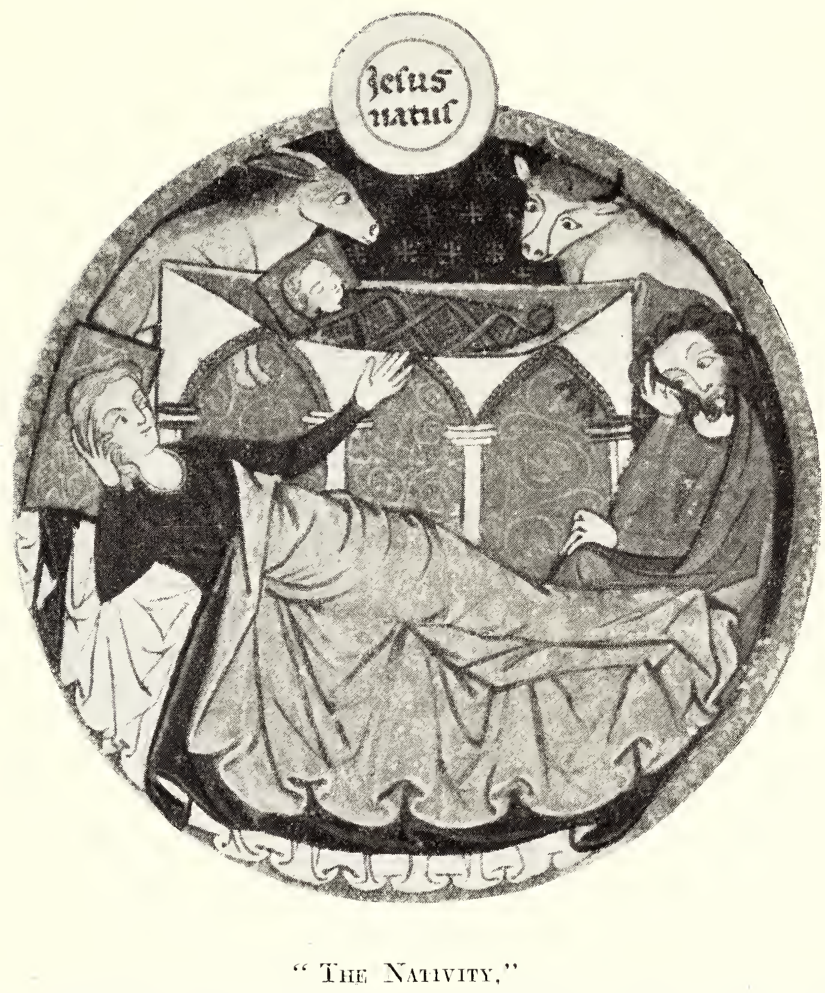

A Miniature (equal size) from "Geneatogr of Jests," XIIIth Century Us. Roll written and illuminated by an Engli-h Artist.

With 6 Minatures.

England, XIILth Century.

See Ttem No. 6. 


\section{Plare V'll.}

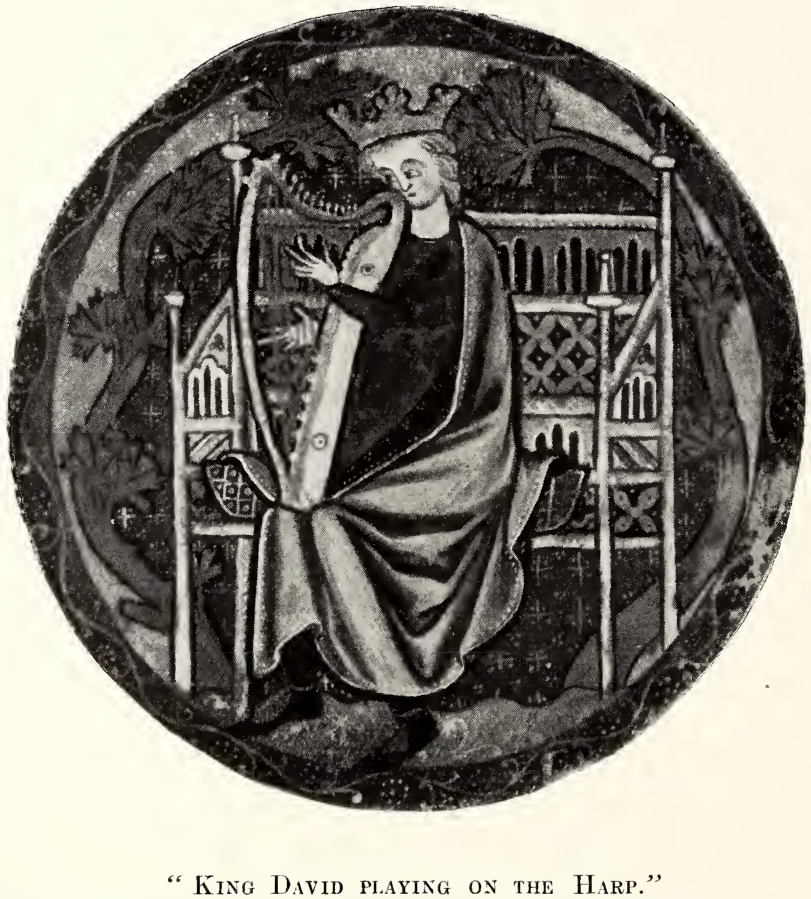

A Miniature (equal size) from " Geneazogy of Jesus," XIIIth Century MS. Rol. written and illuminated by an English Artist.

With 6 Minatures.

England, XIIIth Century.

See Item No. 6. 
Thirteenth Century Manuscript Roll, Written and Illuminated BY AN ENGLISH ARTIST.

6 A GENEALOGY OF JESUS FROM ADAM, with notes of ancient monarchs, etc., ending with the martyrdom of Saint Paul. At end is a tract with map of the 1tinerary of Jesus, with short note "de igne aeterno," " on Hell-fire."

LATIN MANUSCRIPT BEAUTIFULLY WRITTEN AND ILLUMINATED BY AN ENGLISH SCRIBE IN THE THIRTEENTH CENTURY IN ROLL FORM ON A LONG STRIP OF VELLUM.

WITH SIX MAGNIFICENT CIRCULAR MINIATURES DESIGNED AND ILLUMINATED BY AN ENGLISH ARTIST, IN GOLD AND COLOURS, AND SEVERAL CURIOUS DIAGRAMS, SOME IN COLOURS, INCLUDING A SKETCH OF THE EIGHT-BRANCHED CANDLESTICK.

(England. End of XIIIth Century).

(See Illustrations, Plates Nos. Vi. and VII.).

$£ 250$

List of Miniatures:-

No. 1. Adam and Eve tasting the forbidden fruit after temptation by the serpent.

No. 2. Noah building a large boat.

No. 3. Abraham, on Mount Moriah being called by the Angel, and told to sacrifice a ram, instead of his only son.

No. 4. King Bavid playing on the harp.

No. 5. King Zedekiah sitting cross-legged on his throne.

No. 6. The Nativity.

There are some peculiarities in this curious roll. The preface and certain other parts of the text are not given in their usual place but are written on the back of the scroll. In place of the preface, is an abridgement of the first twelve chapters of the Historia Scholastica of Petrus Comestor. The authorship of the text has sometimes been assigned to Petrus Pictaviensis.

\section{PETRUS DE RIGA.}

\section{Aurora. Biblia latina Metrificata.}

THIRTEENTH CENTURY MANUSCRIPT, FINELY WRITTEN ON I 78 LEAVES OF VELLUM, IN RED AND BLACK, WITH INITIALS IN BLUE AND RED.

$8 \mathrm{vo}$, brown calf.

(France, XIIIth Century).

$£ 1212 \mathrm{~s}$

This manuscript contains a brief resumé in Latin rhyming verse of the main incidents of the Old and New 'Testaments. The manuscript is written in a very fair hand. A note on the second leaf indicates that this manuscript was presented to the Jesuit College at Agen in France by Bernard Carles, a bookseller at Toulouse, in the year 1599 . 
Superb Fourteenth Century Illuminated Manuscript of the "ROMAN DE LA ROSE."

8 LORRIS (Guillaume de) and JEAN DE MEUN, dit Clopinel.

\section{Le Roman de la Rose.}

FRENCH (XIVth CENTURY) ILLUMINATED MANUSCRIPT ON I 42 LEAVES OF VELLUM ( I I $\frac{1}{2}$ by $8 \frac{1}{8}$ INCHES) WRITTEN IN GOTHIC CHARACTERS, IN DOUBLE COLUMNS, 40 LINES TO A FULL PAGE.

ILLUSTRATED WITH ONE'LARGE AND 4.I SMALLER OBLONG MINIATURES, FINELY EXECUTED IN GOLD AND COLOURS, USUALLY ON VARIOUSLY DIAPERED BACKGROUNDS, SOMETIMES ON SOLID GOLD GROUNDS. SMALLER INITIAL LETTERS PAINTED IN RED AND BLUE ALTERNATELY WITH PEN DECORA'TION. THE FIRST PAGE HAS A LARGE. INITIAL' LETTER WITH STRAP ELONGATIONS FORMING BORDERS, DECORATED WITH PEN SCROLLS AND IVY LEAVES IN GREEN AND GOLD A'T INTERVALS, IN THE FORE AND LOWER BORDERS OCCUR SMALL MEDALLION HEADS (SIX IN ALL), AT 'THE HEAD OF' THE PAGE IS THE VERY LARGE MINIATURE IN GOLD AND COLOURS IN FOUR COMPAR'TMENTS.

Small folio, old rough calf.

(France. About A.D. I330).

(See Illustration, Plate No. ViII.).

Folio 86 is missing and the last leaf has been repaired touching a few words.

The Story of the Roman de la Rose is this, on a beautiful spring day a young man goes to sleep and dreams that he is in a beautiful garden in which he sees a rose of exquisite beauty. He goes to gather it, but a thousand obstacles prerent him. At last, in his adrenture, or as the tale ends:-

"Ains ens la rose vermeille, A tant fut jour et je m'éreille."

9 PETRUS DE RIGA.

\section{Aurora, Biblia latina Metrificata.}

THIRTEENTH CENTURY MANUSCRIPT, FINELY WRITTEN ON I24 LEAVES OF VELLUM BY AN ITALIAN SCRIBE. WITH INITIAL CAPITALS PAINTED IN BLUE AND RED.

8vo, brown crushed morocco extra, g. e.

(Italy, XIIIth Century).

$£ 1212 s$

This manuscript contains a brief resumé in Latin rhyming verse of the main incidents in the Old and New 'Testaments. The manuscript is written in a very legible hand. 
Plate VIII.

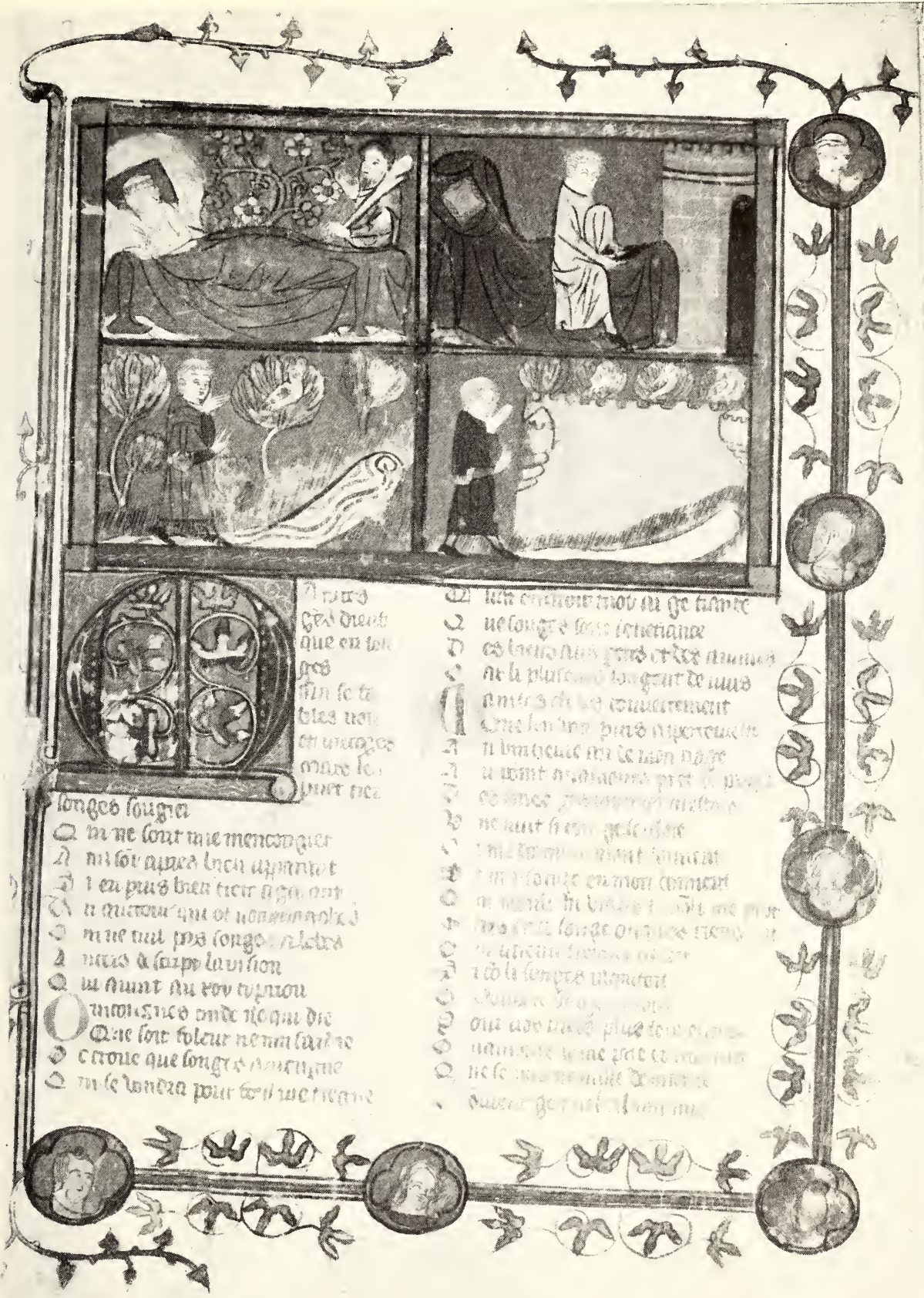

Opening page (greatly reduced) from LorRIS AND JEAx DE MEcx. Le Romax de LA Rose. Superb illmminated MS. Romance of Chivalry on rellum. France. about A.D. 1330. See Item No. 8. 


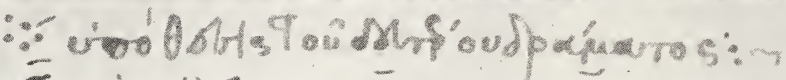

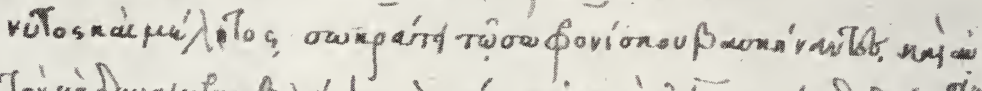

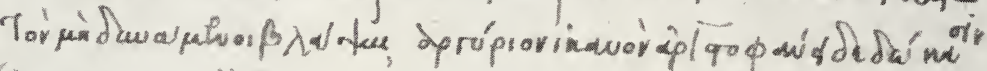

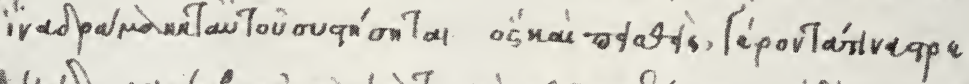

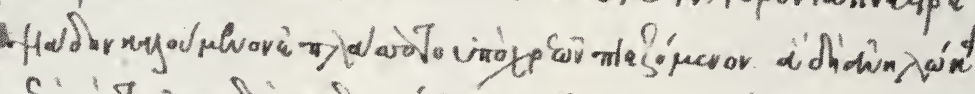

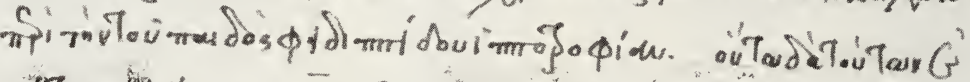

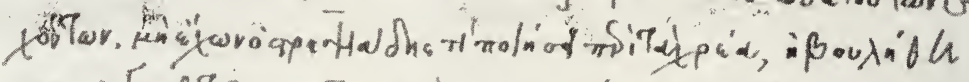

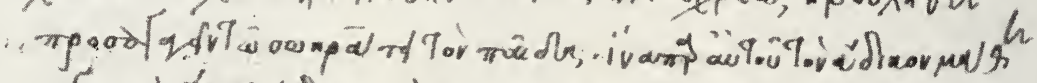

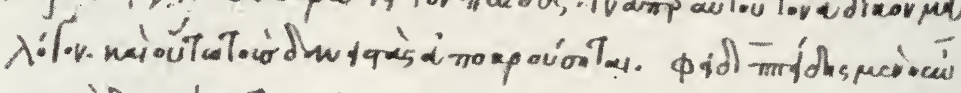

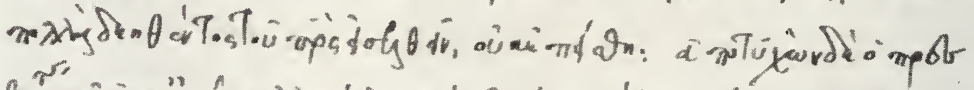

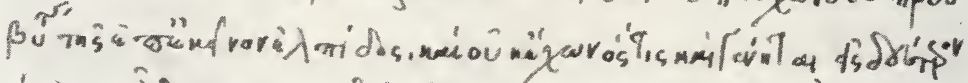
"Qdofvid

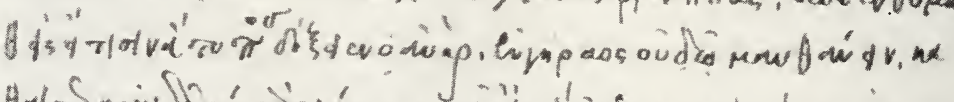

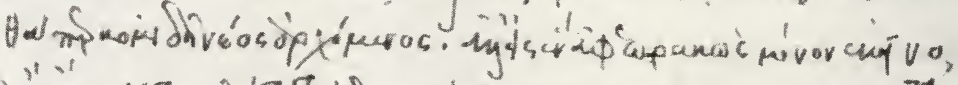

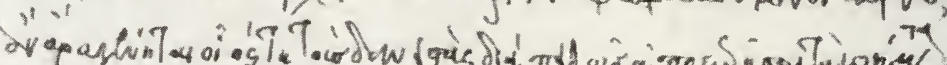

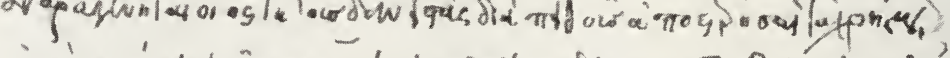

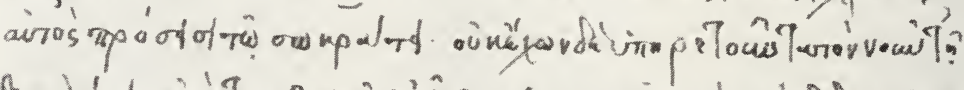

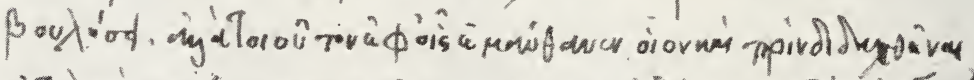

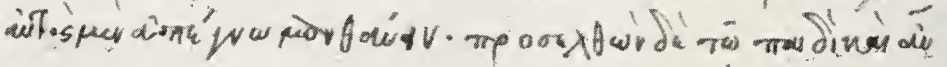

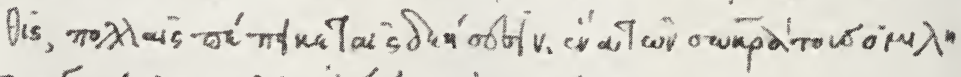

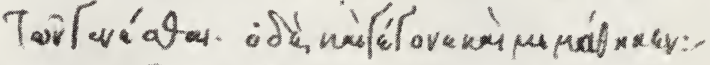

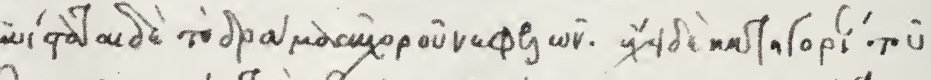

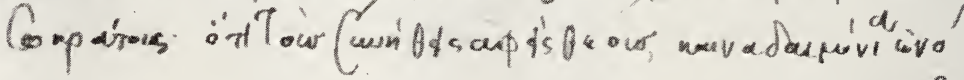
mise

A page (equal size) from Aristonhanes. Plutes and the Clouds. Greek Manuscript on 171 leaves of Oriental paper.

Constantinople, XIVth Century.

See Item No. 10. 
MAGGS BROS., 34 \& 35, Conduit Street, London, W.

Manuscript in Greek of Aristophanes.

\section{io ARISTOPHANES.}

Plutus and the Clouds (in Greek).

NEATLY WRITTEN MANUSCRIPT ON ORIENTAL PAPER ON I 7I LEAVES, 8 LONG LINES TO A PAGE, WITH COMMENTARIES NEATLY WRITTEN IN THE MARGIN, GLOSSES IN RED, 2 ORNAMENTAL BORDERS IN RED.

THE WORK OPENS WITH A SHORT BIOGRAPHY OF ARISTOPHANES.

4.to, half bound.

(Italy, XIVth Century).

(See Illustration, Plate No. IX.).

$£ 5210 \mathrm{~s}$

The manuscript bears a stamp "De Casa Minutoli Tegrimi." A few leaves slightly wormed and a leaf missing between folios 14 and 15 . From the Firmin Didot Collection.

GREEK MANUSCRIPTS ARE EXCESSIVELY RARE.

Given by the Author to the Library of Fountains Abbey, Yorks.

\section{I HENRY OF KNARESBOROUGH.}

Collectanea. Sermones Henrici de Knaresborough; beng Latin Sermons and other religious collections.

ENGLISH XIIITH CENTURY MANUSCRIPT WRITTEN IN SMALL FINE LEGIBLE CHARACTERS ON 300 LEAVES OF VELLUM ( $7 \frac{1}{4}$ by $5 \frac{3}{4}$ INCHES). IN DOUBLE COLUMNS AND LONG LINES. (IN VARIOUS HANDS). WITH FINE INITIAL LETTERS DRAWN WITH PEN AND INK AND PAINTED RED, GREEN, BLUE, ETC., SOME WITH MARGINAL ELONGATIONS.

WITH OLD INSCRIPTION ON FLY LEAF “ LIBER SANCTAE MARIE DE FONTIBUS EX DONO DOMINI HENRICI DE KNARESBURC." " COLLECTANEA HENRICI DE KNASBURGO IN PRIMA CLASSE CODICUM PGL. OCTAVO.

Small 4to, original XIVth century binding of oak boards coverea? with sheepskin.

(England, XIVth Century).

$£ 63$

The author mentions St. Augustine and the Introduction of Christianity into England. 


\section{BIBLE.}

\section{By a Fourteenth Century English Scribe.}

Biblia Sacra Latina, versio vulgata, cum prologo S. Hieronymi. LATIN MANUSCRIPT ON THIN VELLUM, ON 342 LEAVES ( I $1 \frac{1}{2}$ by $7 \frac{1}{2}$ INCHES), CLEARLY WRITTEN IN GOTHIC LE'TERS, DOUBLE COLUMNS, 53 LINES TO A PAGE, RUBRICATED.

WITH HUNDREDS OF INITIAL LETTERS PAINTED IN RED AND BLUE, MANY INITIALS HAVING ELONGATIONS AND PEN ORNAMENTS,

Folio, old caif.

(England, XIVth Century).

$£ 85$

The manuscripts contains the whole of the books of the Old Testament and in addition the Book of Macchabees.

I. CHRYSOSTOMUS (Johannes).

Homilies (in Latin).

LATIN MANUSCRIP'T ON VELLUM, WRITTEN BY AN ENGLISH SCRIBE, XIVth CEN'TURY, 42 LONG LINES TO A FULL PAGE, WI'TH NUMEROUS INITIAL LET'TERS ORNAMENTED IN RED AND BLUE.

Thick folio, half calf.

(England, XIVth Century).

$£ 1414 \mathrm{~s}$

In addition to the above mentioned work the manuscripts contain various other theological chapters, such as the compendium theologiae of Thomas Aquinas, etc.

Fourteenth Century Manuscript of Euclid Written in England.

\section{I4 EUCLID.}

\section{The Fifteen Books of Euclid's Elements.}

WRITTEN IN LATIN ON I 52 LEAVES OF VELLUM (9 by $5 \frac{3}{8}$ INCHES) BY AN ENGLISH SCRIBE IN THE FOURTEENTH CENTURY IN SMALL GOTHIC LETTERS. INITIALS PAIN'TED IN BLUE WITH RED PEN FLOURISHES. WITH NUMEROUS GEOMETRICAL DESIGNS TO EUCLID'S PROPOSITIONS VERY NEATLY DRAWN IN RED IN THE MARGINS.

ACC. Campanus, Tetragonismus, id est circuli quadratura, WITH GEOMETRICAL DESIGNS IN RED.

8vo, veilum.

(England. XIVth Century).

(See Illustration, Plate No. X.)

In 1487 the manuscript was in the possession of Richard Brynkley, who has written his name and the date in Greek characters at the end of the rolume. This Richard Brynkley was an important official of the Franciscan Order in England. 


\section{Int}

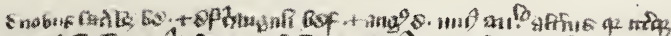

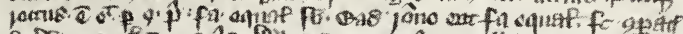

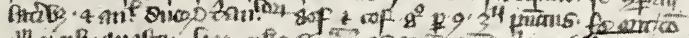

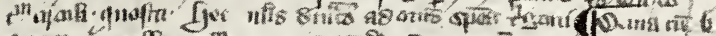

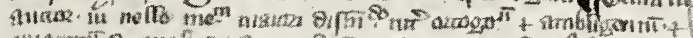

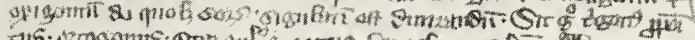

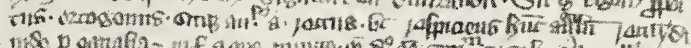

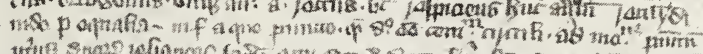

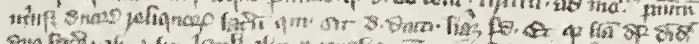

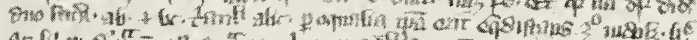

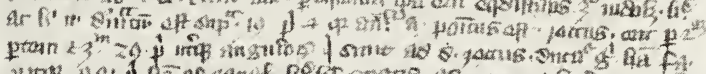

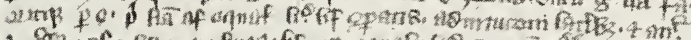

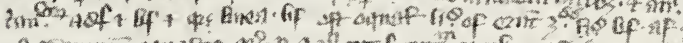

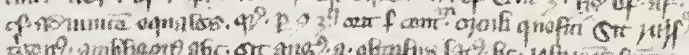

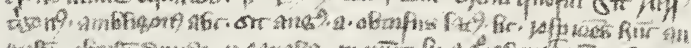

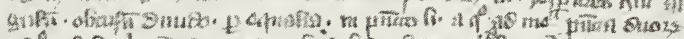

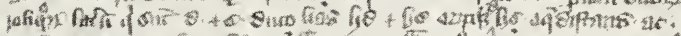

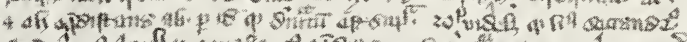

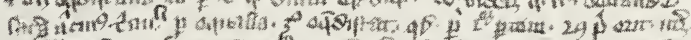

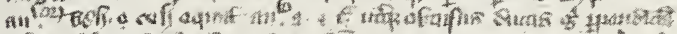

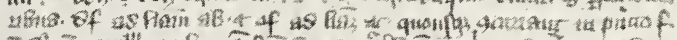

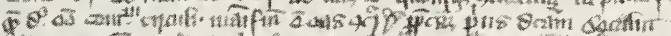

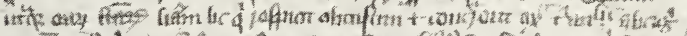

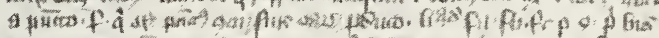

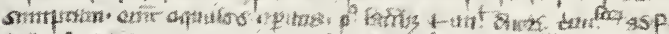

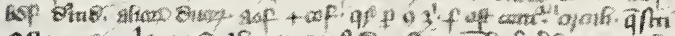

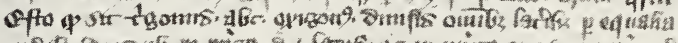

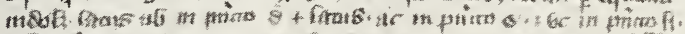

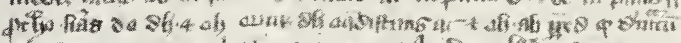

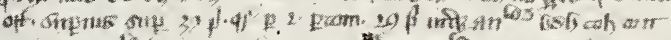

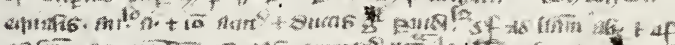

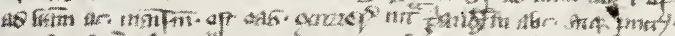

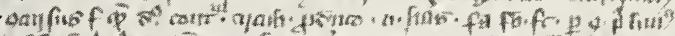

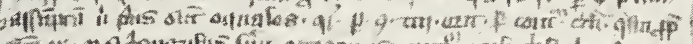

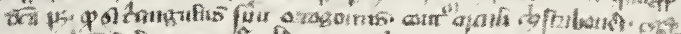

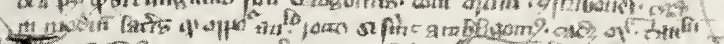

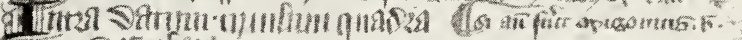
Tiin sptabist.

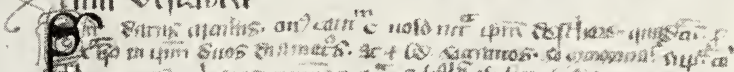

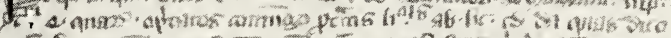

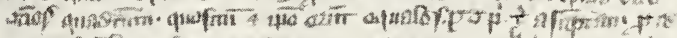

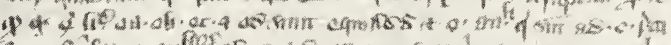

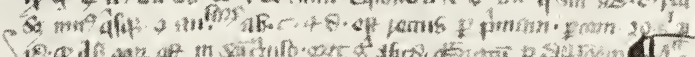

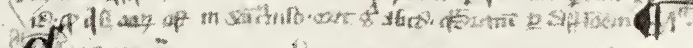
Q

C

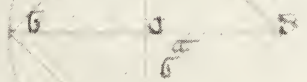

s.

A page (reduced) from the “ Fiftrex Books of Euclid's Elements.'

Manuscript written in Latin by an English scribe on 152 leaves of rellum.

With numerous geometrical designs.

England, XIVth Century.

See Item No. 14. 


\section{I5 SERMONES.}

\section{Collection of Sermons in Latin.}

MANUSCRIPT WRITTEN IN SMALL GOTHIC CHARACTERS BY AN ENGLISH SCRIBE ON I 88 LEAVES OF VELLUM ( 9 by $6 \frac{1}{4}$ INCHES), 35 LONG LINES TO A PAGE. (XIVth CENTURY). WITH PEN FLOURISHED INITIAL LETTERS IN BLUE. 4to, original sheepskin covers.

(England. XIVth Century).

i6 Collectanea.

LATIN MANUSCRIPT CONTAINING EIGHT TREATISES WRITTEN ON VELLUM BY AN ENGLISH SCRIBE, AT THE END OF THE FOURTEENTH CENTURY, INITIALS PAINTED RED AND BLUE, LONG LINES, 22 TO A FÚLL PAGE.

$$
\begin{aligned}
& \text { 8vo, calf. } \\
& \text { (England, XIVth Century). }
\end{aligned}
$$

(1) St. Isidore. Two books of soliloquies.

(2) Directions to a priest for dealing with penitents and other parishioners, beginnin.r with a quotation from St. Chrysostomus.

(3) St. Augustine. De conflictu vitiorum et virtutum.

(4) De significatione Passionis Salvatoris, explaining certain observances in Holy Week.

(5) Disciplina bona.

(6) Instruction to a priest for dealing with penitents and at end of the instruction, a form of absolution from excommunication.

(7) St. Augustine. De occupatione bona.

(8) The Constitutions of Archbishop Peckam.

Romance of Saint George and the Dragon in Catalan.

\section{I7 SAINT GEORGE.} sent Jordi.

La Vida del Benaventurat Cavaller he glorioso martir no senyor ROMANCE OF CHIVALRY IN CATALAN (SPAIN, XIVth CENTURY) WRITTEN BY A SPANISH SCRIBE ON 32 LEAVES OF VELLUM, WITH INITIAL LETTERS DRAWN IN PEN AND INK (IN RED AND BLUE), WITH PARAGRAPH-MARKS AND INITIALSTROKES IN RED, 24 LONG LINES TO A FULL PAGE.

WITH VERY CURIOUS MINIATURE OF ST. GEORGE PIERCING THE DRAGON AND RESCUING A LADY IN A BLUE COSTUME COVERED WITH STARS.

4 to, original vellum.

(Spain. End of XIVth Century).

$£ 26$

Some pages water-stained interfering with text. 
MAGGS BROS., 34 \& 35, Conduit Street, London, W.

MAGNificently ILlUminated, FROM THE LibRaRy OF THE ARCHBISHOP

\section{IS HORA.} OF LYONS.

Horæ Beatæ Mariæ Virginis, cum Kalendario.

A MAGNIFICENTLY ILLUMINATED MANUSCRIPT ON+228 LEAVES OF FINE VELLUM ( $9 \frac{1}{2}$ by $6 \frac{3}{4}$ INCHES), WRITTEN BY A FRENCH SCRIBE AT THE END OF THE FOURTEENTH CENTURY.

BEAUTIFULLY WRITTEN IN LARGE AND CLEAR GOTHIC CHARACTERS, I6 LONG LINES TO A FULL PAGE, THE CALENDAR IS WRITTEN IN GOLD, RED AND BLUE WITH RICHLY DECORATIVE INITIAL LETTERS AND FULL BORDERS AND ALSO TWELVE CIRCULAR MINIATURES IN GOLD AND COLOURS ILLUSTRATIVE OF THE SIGNS OF THE ZODIAC.

WITH 24 SUPERB MINIATURES VERY FINELY EXECUTED BY TWO OR MORE. ARTISTS, ONE OF THE ARTISTS BEING ONE OF THE GREAT UNNAMED MASTERS OF FOURTEENTH CENIUURY FRENCH MINIATURE ART. WITH 455 ESPECIALLY LARGE AND FULL FLOREATED BORDERS (BEING ONE TO EVERY PAGE) COMPOSED OF ELABORATE AND MINUTE PEN SCROLL WORK OF A MOST TASTEFUL FLOREATE PATTERN WITH IVY LEAVES IN GOLD AND COLOURS, OCCASIONALLY'A BROADER DESIGN HAS BEEN USED AND SOMETIMES THERE ARE CHARMING DESIGNS OF GROTESQUE BIRDS AND ANIMALS.

ALSO MANY HUNDREDS OF LARGE AND SMALL ORNAMENTAL INI'TIAL LETTERS IN BURNISHED GOLD AND COLOURS AND MUCH TEXTUAL DECORATION.

Royal 8vo, old calf gilt, on the sides are borders and frames of gilt floreate scroll work, with centre and corner panels containing i'ase ornaments, g. e., in the old box which was made for the book at the time of the binding (formerly in the possession of Monseigneur de Villeroi, Arcibishop of Lyons).

(France. End of XIVth Century.)

(See Illustration, Plate No. XI.).

$£ 4,200$

A SUPERB EXAMPLE OF THE FINEST STYLE OF THE ILLUMINATOR'S ART OF THE BEST FRENCH SCHOOL AT THE END OF THE 14th CENTURY, (Continued over) 
Horæ-continued.

WRITTEN FOR A ROYAL CHAPEL, AS TESTIFIED BY THE FLEUR-DE-LYS ADORNING THE CEILINGS OF THE CHAPEL IN THE MINIATURE OF THE ANNUNCIATION (No. 5). THE CONDITION OF' THE MANUSCRIPT, MINIATURES AND BOFDERS IS UNRIVALLED, AND IT IS ALMOST A MIRACLE THAT IT HAS ESCAPED 'THE RAVAGES OF TIME, WHICH IS NO DOUBT OWING TO THE FAC'T THAT I'T HAD BEEN CAREFULLY HANDED DOWN AND 'TREATED AS A FAMILY HEIRLOOM SINCE 1565, AS LONG MANUSCRIPT DESCRIPTIONS OF FORMER OWNERS, CANONS OF THE CHURCH A'T POICTIERS AND MEMBERS OF THE GAYAND AND GAUDON FAMILIES OF POICTIERS ATTEST, ONE OF WHOM HAS ADDED THE DATE AND PRICE OF BINDING THE MS. AND MENTIONS THE OLD BOX IN WHICH IT IS STILL PRESERVED. 'IHE DESCRIP'TIONS FORM A LONG PEDIGREE SINCE 1565.

THE MINIATURES ARE PAINTED MOST DELICATELY AND WITH SUPREME GOOD 'TASTE IN GOLD AND BRILLIANT COLOURS, NEARLY ALL OF 'THEM HAVE BEAUTIFUL RICHLY DIAPERED BACKGROUNDS.

They represent:-

1. St. John the Evangelist (with his attribute) writing, the devil stealing his inkpot and emptying it into the sea.

2. St. Luke the Evangelist.

3. St. Mathew the Erangelist.

4. St. Mark the Evangelist.

5. The Annunciation.

6. The Visitation.

7. The Nativity.

8. The Angel appearing to the Shepherds.

9. The Presentation in the Temple.

10. The Flight into Egypt.

11. The Coronation of the Virgin.

12. King David praying.

13. The Betrayal.

14. Jesus before Pilate.

15. The Crowning with Thorns.

16. The Crucifixion.

17. Jesus bearing the Cross.

18. The Descent from the Cross.

19. The Entombinent.

20. Jesus on the Cross, the two Maries at the foot.

21. The Descent of the Holy Ghost.

22. The Vigil of the Dead.

23. The Virgin and Child with the Angels.

24. The Day of Judgment.

It is not easy to select the finest miniatures in this superb manuscript, but we should like to point out No. 23. The Virgin and Child, a composition of tranquil beauty and purity; No. 22, one of the finest miniatures we have ever seen, in which the characterisation of the attendants and choir is carried so far that every one of the semi-hooded monks has a different expression; No. I3, The Betrayal, a magnificent night-piece with superbly contrasted colours, and in which every face is characterised; No. I2, King David praying, includes delightful country scenes with a mill, and with a stream painted with silver, a colour rarely used by miniaturists. 


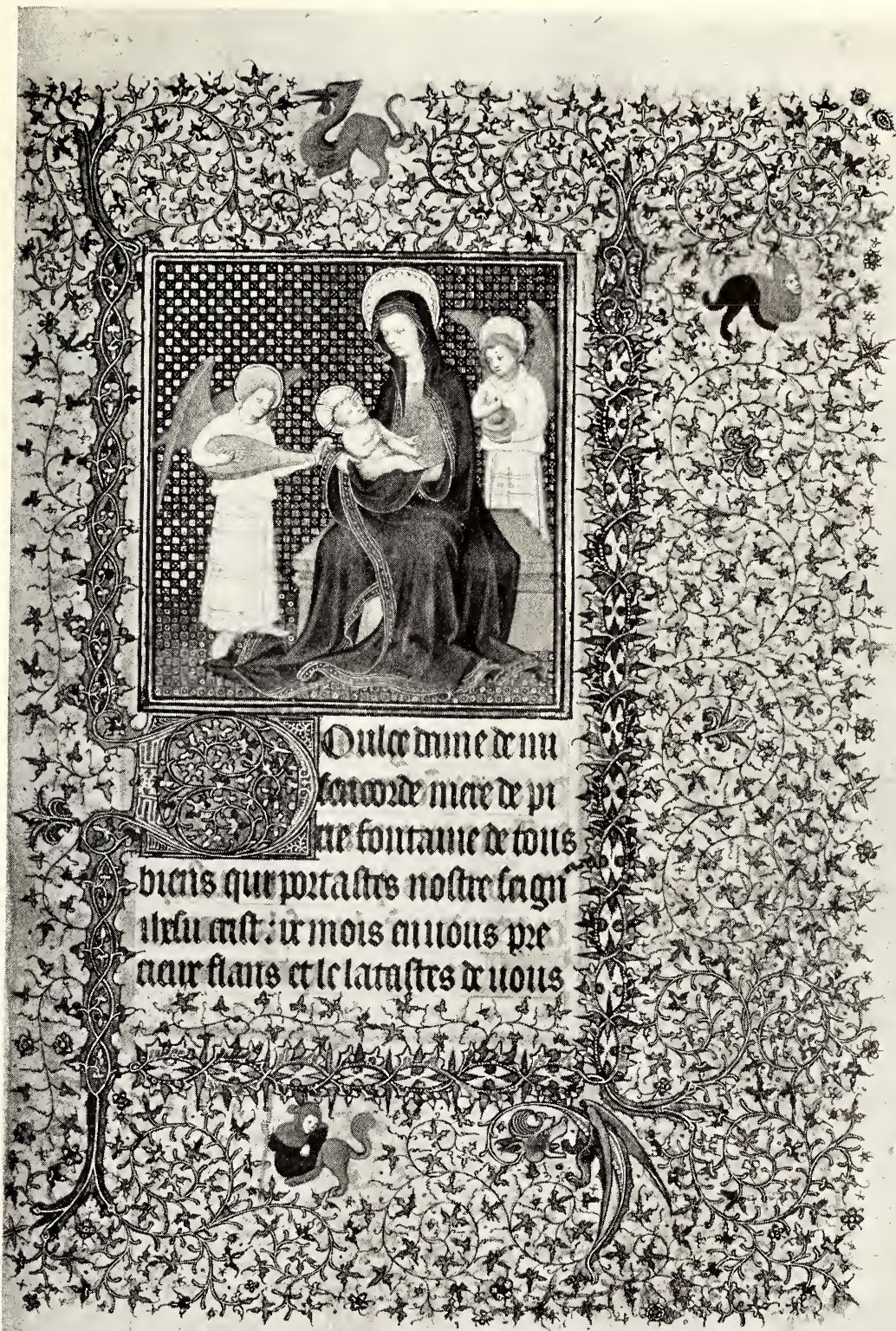

A page (greatly reduced) from Horae Beatae Mariae Virgisis.

Superb Illuminated Book of Hours on vellum with 24 magnificent Miniatures and 455 floreated borders.

France, End of XIVth Century. 


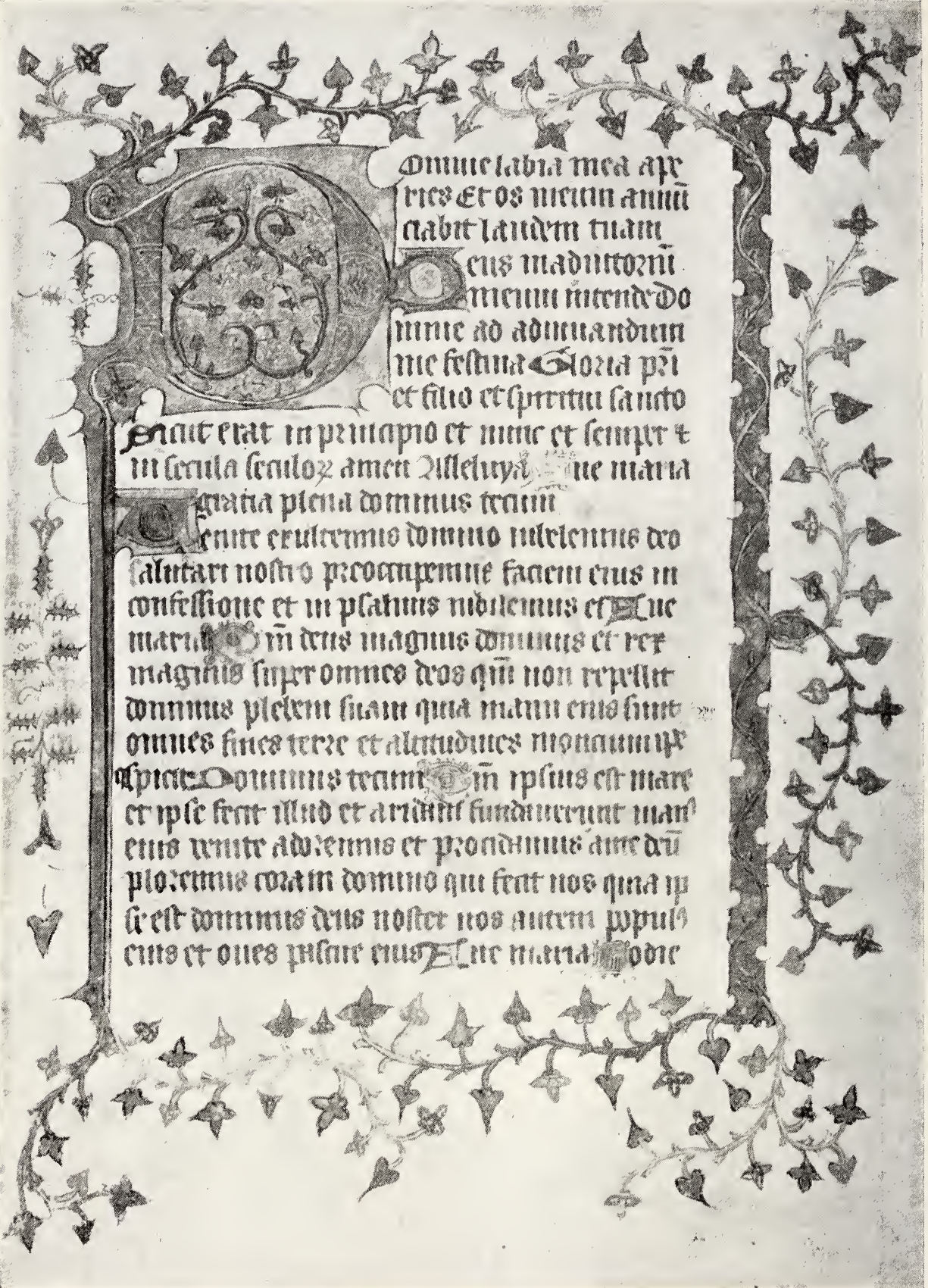

First page (equal size) from Horae Beatae Marlae Virginis.

English Illuminated Book of Hours on ve!lum with 2 large Miniatures. England, XIVth Century. See Item No. 19. 


\section{English Fourteenth Century Horae.}

\section{I9 HORE.}

Horæ Beatæ Mariæ Virginis, cum Kalendario,

ILLUMINATED MANUSCRIPT (ENGLISH XVth CENTURY) ON 68 LEAVES OF VELLUM ( $7 \frac{1}{8}$ by 5 INCHES) WRITTEN BY AN ENGLISH SCRIBE IN LATIN IN NEAT GOTHIC CHARACTERS, 24 LONG LINES TO A PAGE.

WITH 2 LARGE MINIATURES IN GOLD AND COLOURS, ONE OF SAINT JEROME, THE OTHER THE OFFICE FOR THE DEAD. WITH SEVERAL LARGE ORNAMENTAL INITIAL LETTERS, BEAUTIFULLY EXECUTED IN GOLD AND COLOURS, WITH MARGINAL ELONGATIONS FORMING PARTIAL OR FULL BORDERS, DECORATED WITH FLOREATE SCROLLS.

Small 4to, vellum.

(England, XIVth Century).

(See Illustration, Plate No. XiI.).

$£ 5210$ s

The Ingilby Psalter.

A Fourteenth Century English Manuscript of the Psalter, Translated BY RichaRd ROLle of HaMPOLE.

20 THE INGILBY PSALTER, MANUSCRIPT ON 220 LEAVES OF VELLUM (ENGLISH XIVth CENTURY). WRITTEN IN LATIN AND ENGLISH, IN GOTHIC CHARACTERS AND BOOK-HAND. DOUBLE COLUMNS, 40-47 LINES TO A FULL. PAGE (IO5 by $7 \frac{3}{4}$ INCHES).

Small folio, old calf.

(England, XIVth Century.)

$£ 350$

The Psalter is preceded by two pages of introduction which begins " Grete Habundant of Gastli cumforth and joy in God cummes in to ye hertes of thame yt saies or synges devouteli ye psalmes of ye sauter."

22 leaves at the beginning of the volume are occupied by a treatise in another hand "here begynes ye Holy Boke Gra Dei"; and beginning "Off God's grace sterand helpande, and that without grace no gode may be done," after the Psalter follow 18 leaves in a different hand, containing various treatises or homilies, beginning "The comawmde of god is that we luf our lorde, in all oure hert."

With several initials illuminated in gold and colours and numerous initial letters drawn in red and blue, paragraph-marks in red and blue alternately.

The famous Ingilby psalter (noted in " a fourteenth century biblical version, Cam. bridge, 1902, page xxxiv.”) is one of the uninterpolated copies of the famous psalter of Richard Rolle of Hampole. 'The additional treatises are not noted there. They are as followis:-

1. (Not in the hand of the psalter) An English theological compilation of which C. Horstmann (Yorkshire writers, 1895, vol. 1), printed part.

(Continued over) 


\section{The Ingilby Psalter-continued.}

2. An extract from the "Mirror of St. Edmonds" (Horstmann, pages 221-22).

2A. The "Meditations on the Passion and three arrows on Doomsday" (Horstmann, pages 112-113), This treatise is entitled by Horstmann "De Gratia dei" (page 305), but the amorphous contents really prohibit any title. It was a compilation obviously, but was intended to form one work, for there are several references to it in the text as such.

3. 'The epistle of Richard Rolle (printed by Horstmann (pages 61ff) as "The Commandment of Love to God ").

4, “The Epistle of St. Machary Hermit” (Saint Macarius).

5. “Against boasting and pride” (printed by Horstmann, pages 122ff).

6. "The sayings of the Fathers" (very similar to the collection printed by Horstmann, pages 125ff).

THIS VALUABLE MANUSCRIPT IS WRITIEN IN A NORTHERN DIALECT WHICH CONSIDERABLY ADDS TO ITS INTEREST.

Richard Rolle de Hampole was born about 1290 at Thornton in Yorkshire and died in 1349 .

Richard's ambition was to become a hermit and give himself up to contemplation, his mode of making his profession was to construct for himself a costume from two of his sister's kirtles, one white and another grey, which she lent to him, having borrowed also his father's rainhood he took up his abode in a wood near his father's house. His family naturally looked upon him as out of his senses. He was provided after a time with a titting cell, hermit's clothing and necessaries of life, by the father of some of his Oxford friends. He is represented in the legenda. as living in a spiritual world and having many conflicts with devils in all of which he is victorious. In his de incendia amori he describes in detail the steps in which he reached the highest points of divine rapture; the process occupied four years and three months

Rolle represented a revolt against many of the conventional views of religion in his day. He was a voluminous writer of devotional treatises or paraphrases of scripture. In his literary work he exalted the contemplative life, denounced vice and worldliness, and indulged in much mystical rhapsodising. But he was by no means wholly unpractical in his methods of seeking to rouse in his countrymen an active religious sense. He addressed them frequently in their own language. As a translator of portions of the bible into English-the Psalms, extracts from Job and Jeremiah-he deserves some of the fame subsequently acquired by Wycliff. While he was well read in patristic literature, he had no sympathies with the subtleties of the schoolmen; and when commenting on scripture avoided any mere scholastic interpretation although he often digressed into mysticism of an original type. His popularity was so great that in after times "evil men of Lollardry," as they are described in the rhyming preface to his version of the Psalms, endeavoured to tamper with his writings, with the view of putting forth his authority for their views. Therefore the nuns of the Hampole convent kept genuine copies in "chains bonds" at their house.

Rolle wrote in both Latin and English. His English works were written in a vigorous Northumbrian dia?ect, but they won immediate popularity all over England. and his dialectical peculiarities were modified or wholly removed in the copies made in southern England. 


\section{2i GAZOPHILACIUM.}

(Begins): "Hic incipit prologus. Cupientes aliquid de premiaria ac tenuitate nostra cum Paupercula in Gazophilacium bni mitte," etc. (Libri IV.).

MANUSCRIPT ON VELLUM OF THE XIVth CENTURY WRITTEN IN GO'THIC LEITERS, DOUBLE COLUMNS, 35 LINES, RED RUBRICS, ORNAMENTAL PEN-LETTERS.

Folio, XIVth or Early XVth Century binding of oak boards, and leather, with two medallion stamps (repeated many times), one with figure of a lamb, and Alag surrounded by the name "Jehan de Doienval," the oiher with a figure of a Saint and name "S. E. de la Meaure," with leather bands for fuxing the boards, in pairs.

(England, XIVth Century).

$£ 3110$ s

A few leaves are wanting.

An interesting and uncommon specimen of binding of the XIVth or early XVth century. Some scribblings in English, and the signature "Thomas Ellys"; of the XVIth century, show that the MS. was in England and in York at that period, and the whole production may be English.

\section{A Dainty Psalter.}

\section{PSALTERIUM CUM CALENDARIO.}

LATIN MANUSCRIPT OF THE PSALTER WRITTEN MOST BEAUTIFULLY ON I 36 LEAVES OF THE FINEST VELLUM, BY A FRENCH SCRIBE (FRANCE XIVth CENTURY), 23 LONG LINES TO A FULL PAGE, WITH A LARGE NUMBER OF INITIALS ILLUMINATED IN GOLD AND COLOURS AND HUNDREDS OF SMALL INITIAL LETTERS IN RED AND BLUE ALTERNATELY.

WITH TEN HISTORIATED INITIALS CONTAINING MINIATURES ILLUMINATED IN GOLD AND COLOURS.

I 2mo, brown levant morocco, two-line fillet border on sides, panel back; g. e., stamped ornaments on sides, with leather thongs, by Douglas Cockerell. In beautifully executed casket of leather lined with green plush, with bevelled glass cover, with lock-up top and key. By Sangorski and Sutcliffe.

(France, XIVth Century.) 
Manuscript in English.

23. LAURENCE (Brother, a Dominican Monk).

The Book of Vices and Virtues in English.

ILLUMINATED MANUSCRIPT WRITTEN BY AN ENGLISH SCRIBE (XIVth CENTURY) ON I I 2 LEAVES OF VELLUM (IO $\frac{3}{4}$ by $7^{-1}$ INCHES), IN GO'THIC CHARACTERS, 42 LONG LINES TO A PAGE.

DECORATED WITH I 5 LARGE INITIALS WITH ELONGATIONS FORMING BORDERS OF SLRAP AND BAR WORK ORNAMENTED WITH FLORAL DESIGNS, PAINTED IN BRILLIANT COLOURS AND ILLUMINATED, NUMEROUS SMALLER CAPITALS IN BURNISHED GOLD ON COLOURED GROUNDS.

Folio, original oak boards covered with stamped calf (rebacked).

(England, XIVth Century.)

(See Illustration, Plate No. XiII.).

$£ 210$

With bookplate of Andrew Coltee Ducarel of Doctor's Commons, and inscription “Dec. 5, 1777." This curious MS. was presented to Dr. Ducarel by Mr. Frank Smythies of Colchester. The name of an earlier owner (16th Century) also occurs " Robt. Paynell de Grayes Inne etc." Manuscripts (in Eng?ish) of this work which was first composed in French in the year 1279 are uncommon.

The work was written by Frère Lorens, the Confessor of Philippe III. (" the Bold ") of France, in 1279. It is an expcsition of the Christian Doctrine, containing explanations and commentaries on the Ten Commandments, the Seven Deadly Sins, the Twelve Articles of Christian Belief, etc. It enjoyed a wide popularity in the 14th and 15th centuries, being translated into Dutch and English, editions being printed by Caxton, Wynkyn de Worde and Pynson. The first printed edition of this work in the original French was published in 1502 by Vérard.

\section{The English Legal Statutes.}

24 STATUTA ANGLIE. MANUSCRIPT OF THE FOURTEENTH AND FIFTEENTH CEN'IURIES, WRITTEN ON VELLUM. 324 PP., IN OLD FRENCH AND LATIN.

WITH ORNAMENTAL CAPITALS IN RED AND BLUE.

Small 4to, vellum.

(England, XIVth-XVth Century.)

$£ 25$

The first portion of this valuable Manuscript was written in the Fourteenth Century. The latter part chiefly relates to the Reigns of Henry IV. and VI.

It appears from the Inscriptions occurring in various parts of the volume that it belonged in early times to Thomas Bouryng, "unus Justic, Domini Regis," John atte Style, Stephen Horsswell, and others. 


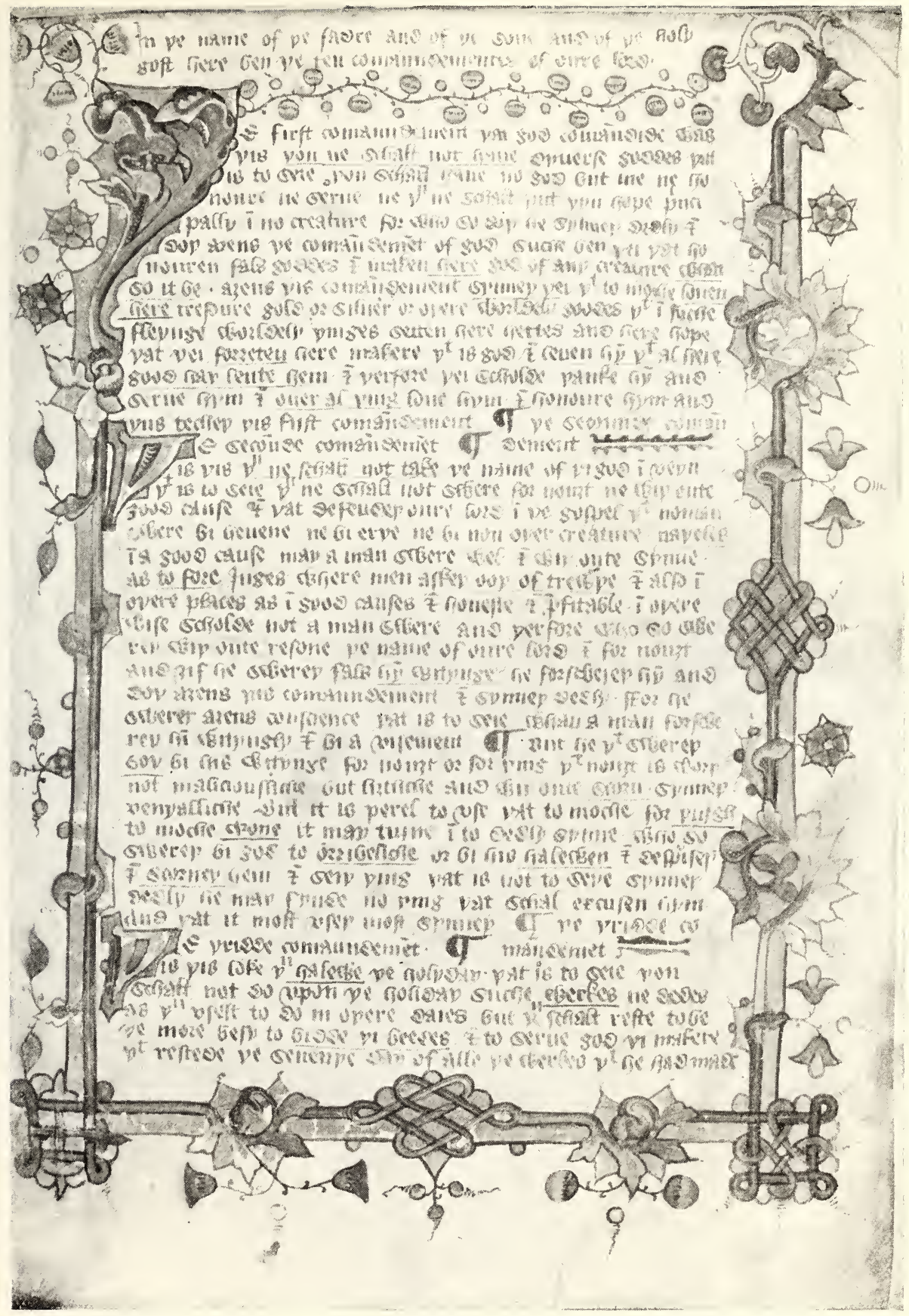

First page (reduced) from Brothfr Laurence's, "The Book of Vices aid Vertues." (In English).

Illuminated English Ms. on 112 leaves of vellum.

England, XIVth Century.

See Item No. 23. 


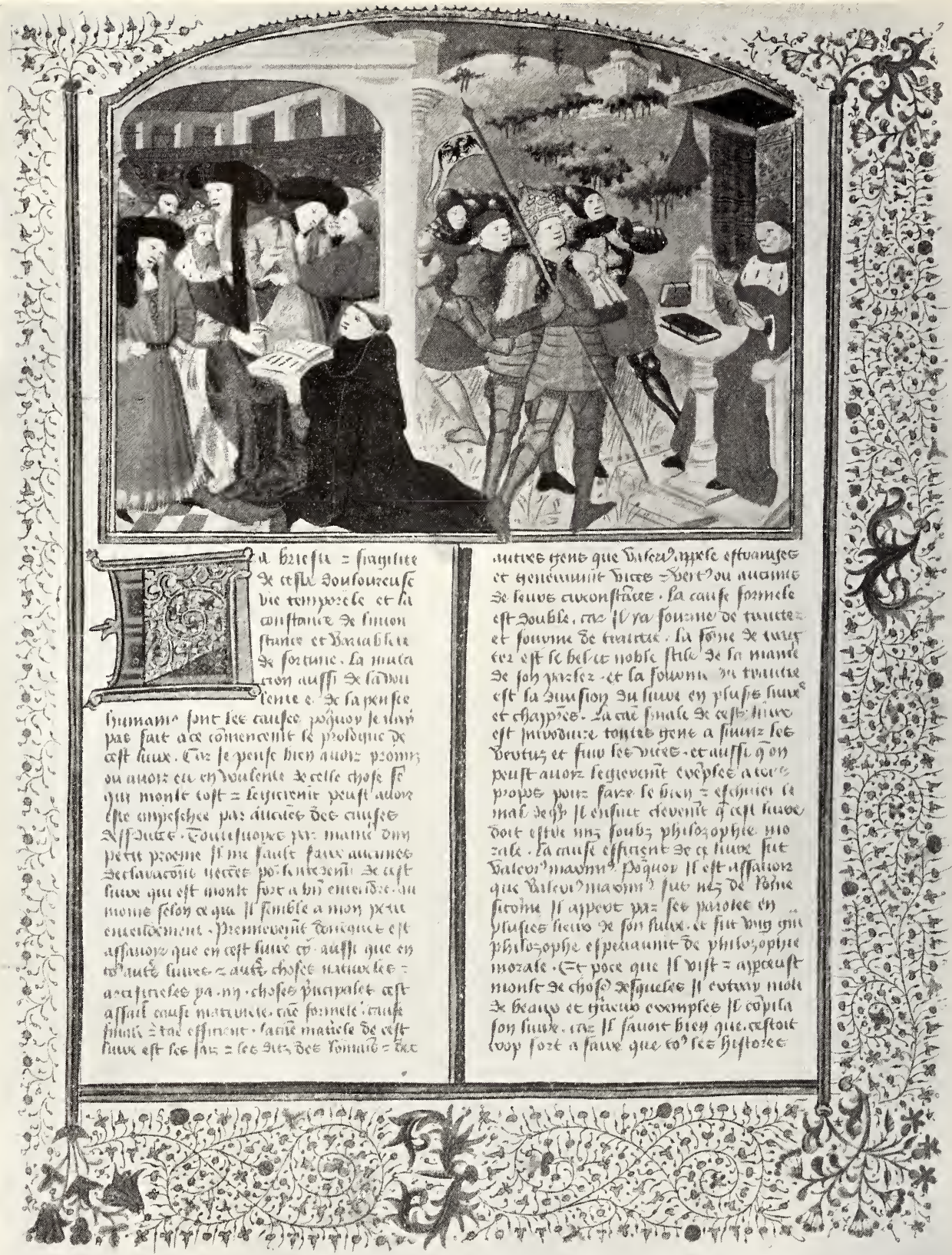

Opening page (greatly reduced) from Valerius Maximus.

"Les faits et les dits des Romains et autres Gens."

Illuminated IIS. in French on vellum translated for the Duc de Berri.

With'9 large Miniatures.

France, about A.D, 1415.

See Item No, 25. 


\section{VALERIUS MAXIMUS.}

\section{Les Faits et les Dits des Romains et des autres Cens.}

ILLUMINATED MANUSCRIPT IN FRENCH, MOST BEAUTIFULLY AND LEGIBLY WRITTEN BY A FRENCH SCRIBE ON ABOU'I 500 LEAVES OF VELLUM, IN LETTRES BATARDES.

WITH NINE BORDERS AND MANY HUNDREDS OF LARGE AND SMALL INITIAL LE'T'TERS BEAUTIFULLY ILLUMINATED IN GOLD AND COLOURS.

\section{ALSO NINE VERY LARGE MINIATURES BEAUTIFULLY DESIGNED AND EXQUISITELY ILLUMINATED IN GOLD, SILVER AND COLOURS.}

Folio, vellum, g. e.

(France. About I4I5).

(See Illustrations, Plates Nos. XIV. and XV.).

The colophon at the end of our manuscript reads as follows: “ L'Exensation du Translateur. Par l'aide divine, sans laquelle nulle chose n'est droitement commencée ne profitablement continuée ne menée à fin, est la translation de Valère le grant terminée; Laquelle commença très Reverend Maistre Simon de Hesdin, maistre en théologie, Religieux des Hospitaliers de Saint Jehan de Jherusalem, qui poursuivi jusques au Vlle livre on chapitre des Stratagèmes et la laissa. Des là en avant jusques à la fin du livre, Je Nicolas de Gonesse maistre ès Arts et en Théologie, ay poursuivi la dite translation au moins mal que j'ay peu, du commandement et ordonnance de très excelent et puissant prince Monseignenr le duc de Berry et d'Auvergne, Conte de Poitou et de Boulogne. A la Requeste de Jacquemin Courau son trésorier. Et ne doubte ne que mon stile de translater n'est ne si bel ne si parfait-comme est celui de devant. Mais je prie à ceulx qui le liront qu'ils le me pardonnent, car je ne suis nie si expert ès histores comme il estoit. Et fut finie l'an mil CCC et ung la veille de Monseigneur Saint Michiel Archangle.

“Et sic est finis hujus historie videlicet Valeriani Maximiniani",

"It appears therefore that the greater part of the translation, so far as Book VII., chapter IV. was by: Simon de Hesdin, a chaplain of the Order of St. John of Jerusalem. His name was presumably derived, like that of the Duke of Berry's famous illuminator Jacquemart de Hesdin, from the town of Hesdin, in Artois." The date at which he entered on his task is supplied by a note which occurs in our Manuscript at the end of Book I., stating that it was completed in 1375, and there is a similar note to Book. II. with the more exact date, 2nd of May, 1377.

"As a rule the Manuscripts have no note, nor even a recognizable break in the text, at the point where Simon de Hesdin's share in the work came to an end. The Paris manuscript (fonds français 282 in the Bibliothèque Nationale, which was probably the earliest copy made of the complete work) is an exception," and our manuscript, the colophon of which is word for word identical with the Paris manuscript colophon, is also an exception, for it contains the following note in red ink: "Cy aprèz commence la nouvele translacion dudit Valerius Maximus. Laquele contient troiz livres si comme j'ay dit cy devant lesquels ont esté translatées parfaits et accomplis par Maistre Nicole de Gonesse Maistre ès arts et en Théologie. Et par ainsi est le livre dudit Valerius tout entier et parfait."

(Continued over) 


\section{Valerius MaxImus-continued.}

"No reason being assigned for the sudden interruption, one can only conjecture that it was caused either by Simon de Hesdin's own death, the date of which is unknown, or by that of his patron Charles V., which occurred in 1380 . In any case, the translation seems to have been suspended for no less than 20 years before it was at length resumed by Nicolas de Gonesse. No more is known of him than of his predecessor, but as the work was begun for Charles V., who founded the famous library of the Lonvre and encouraged so many other translations from Latin into French, it was fittingly brought to an end for his son John, Duke of Berry, who was an equally ardent collector and patron. But it is a question whether the credit for its completion belonged so much to him as to his treasurer, Jacquemin or Jacques Coureau, at whose request, as well as by the Duke's command, Nicholas de Gonesse records that he set about the work. Courau's part seems to be explained by an entry in the catalogue of the Duke's Library referring to the same Paris manuscript 282. It is there described as "Un grant livre de Valerius Maximus histoire et escript de lettre de court . . . . leçuel Sire Jaques Courau lui envoia à extraines le premier jour de Janvier l'an mil CCCC et 1."”

"As the year legally began on the 25th of March, this date is equivalent to the 1st of January, 1402, just three months after Nicholas de Gonesse wrote his co!ophon, on Michaelmas Eve, 1401. There is little doubt therefore that the work was really done at the instance and cost of Courau, and that the Duke merely accepted the volume as a New Year's gift when finished"

In making his translation, Simon de Hesdin, was not content with merely rendering the Latin into French. Both translators added a continuous glossary so that " the text is overwhelmed by the commentary, the two being so intermixed that in spite of the continual repetition of the rubrics 'Acteur' and 'Translateur' it is often difficult to distinguish them apart." Nor was our zealous translator content with this. As he naively reminds his readers, not only was the original work not exhaustive when it was first issued, but much had happened worthy of record during the 1300 years that had since elapsed and accordingly besides the copious illustrative matter embodied in the running commentary, he thought proper to supplement the author's examples with numerous "Addicions du Translateur."

The nine large miniatures prefixed to the nine books are as follows:-

Book I. Of Religrion. Miniature in two compartments.

1. Valerius Maximus, kneeling, presents his book to the Emperor Tiberius, seated in the midst of his court (probably portraits from the Court of the. Duke de Berry).

2. A Royal leader, in full armour bearing a crown on his head and followed by a group of men in armour, approaches a cleric dressed in ermine and purpie who is shown reading a book on a book-stand. Two more books are lying close by. (The men shown probably portraits of the Duke de Berry and his friends.)

Book II. Of Ancient Institutions.

A King being carried in triumph on a litter borne by four white horses, two in front and two behind, while heralds on either side blow long trumpets. In the background a charming landscape.

Bcok III Of Natural Disposition.

A. King in council with five advisers, on the left a peasant is seen bringing offerings of the newly gathered harvest to a Statue.

Book IV. Of Moderation.

A King surrounded by four advisers receives the submission of seven men in armour who oiffer him the hilts of their swords.

Book V. Of Humanity and Clemency. 
Plate XV.

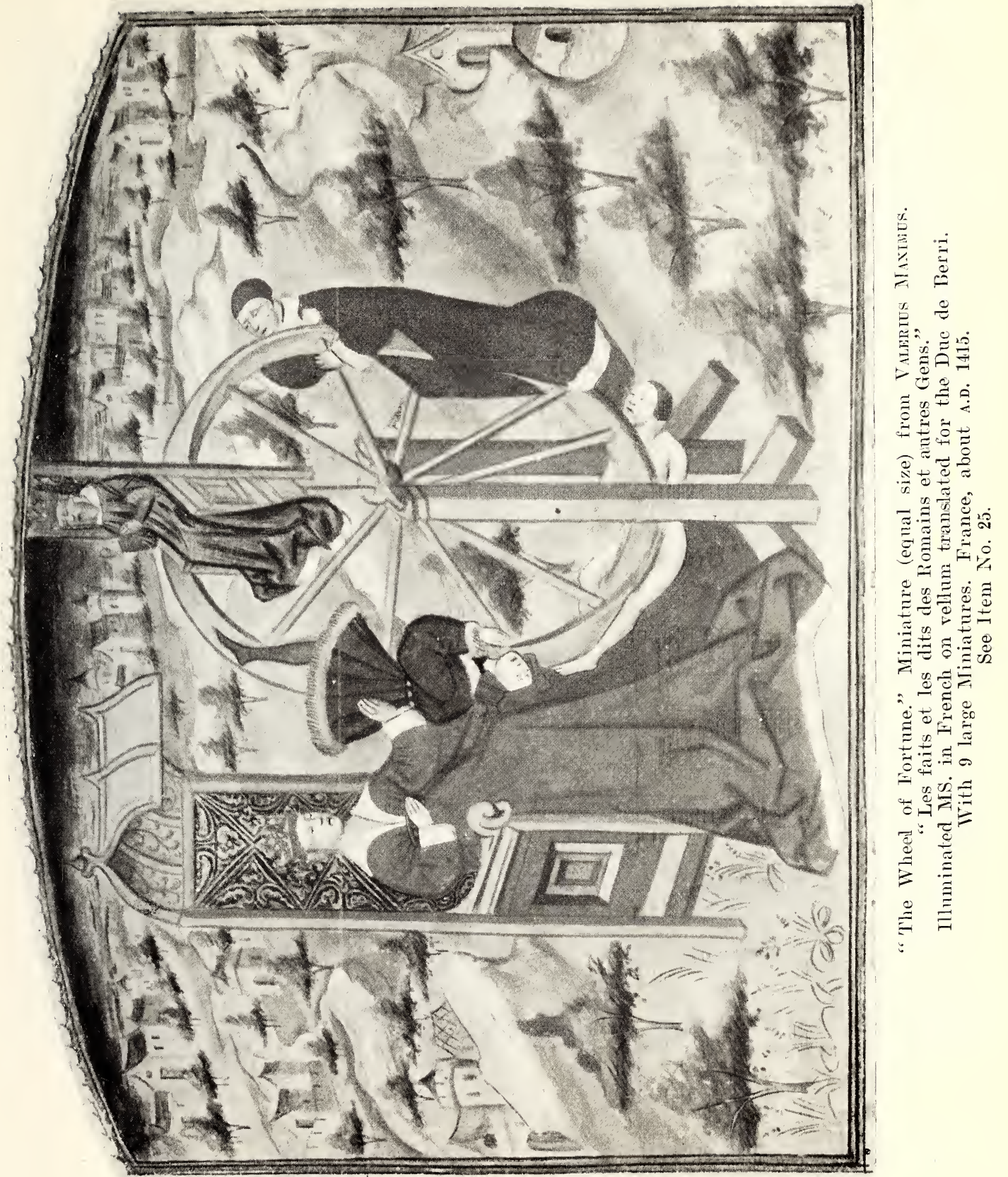




\section{Plate: XVI.}

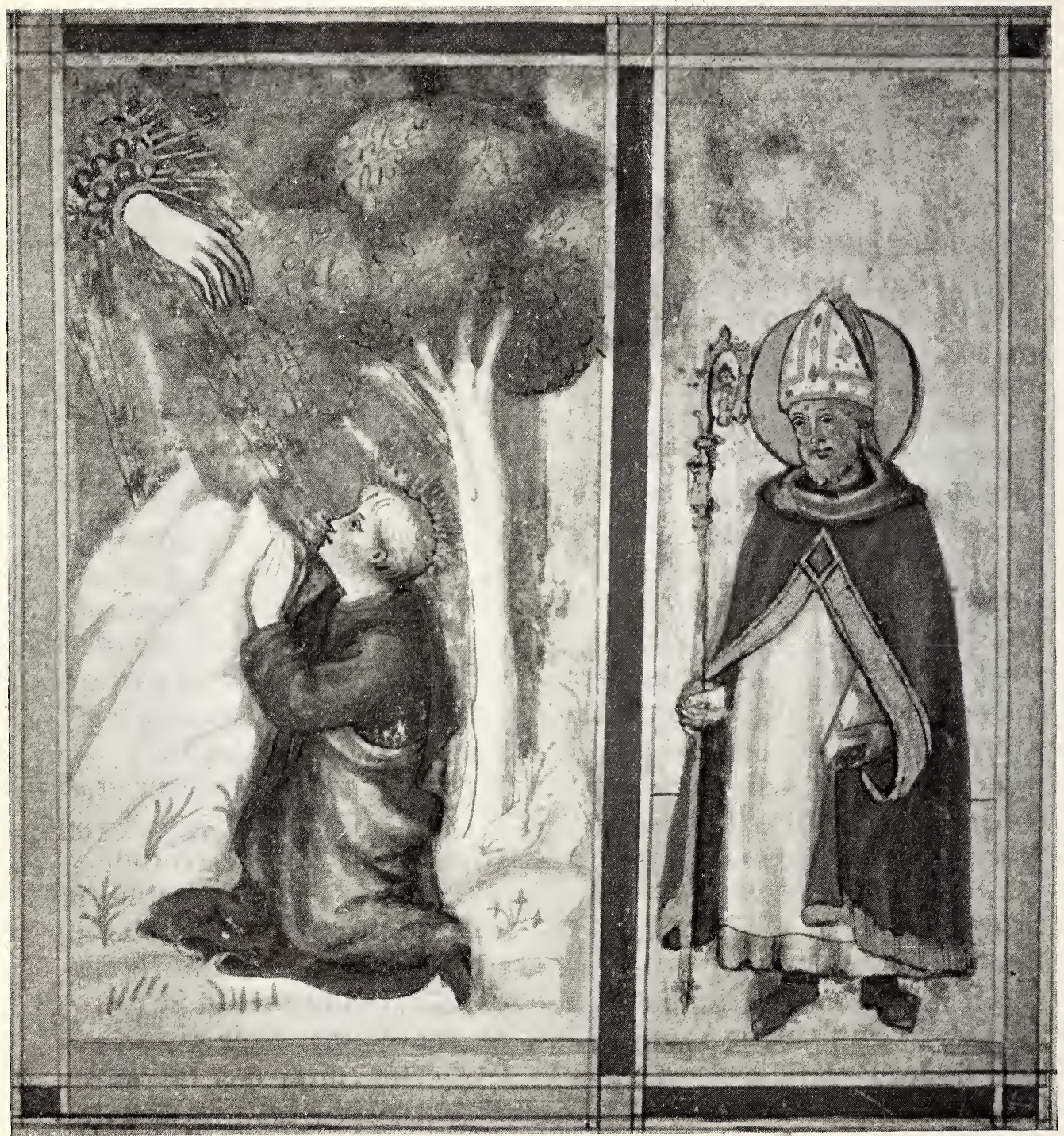

The Miniatures (equal size) from The Confrssions of Sarnt Augustine (in Latin). Illuminated MS. on vellum. Italy, XVth Century.

See Item No. 29. 


\section{Valerius Maximus-continued.}

A King banqueting, four men play various musical instruments on bis left, a charming landscape at back.

Book VI. Of Chastity.

Lucretia (in full Court dress) stabs herself in presence of Collatinus her husband, Lucretius her father, Brutus and Publius Valerius, all well dressed, whose costumes are richly trimmed with fur.

Book VII. Of Happiness.

Fortune and her Wheel, in the midst of a delightful landscape.

Bcok VIII. Of Judgments.

The Romans and Albans, when arrayed for battle, agree to abide by the result of a combat between the three Horatii and the three Curiatii.

Book IX. Of Luxury.

A King is seated on his couch, beneath a tent with a lady in rich attire. In midist of an iriteresting lanciscape.

This work was highly esteemed in the Middle Ages, but except among professed scholars, few probably in these days know more about it than its author's name, and a summary account of its nature and contents may therefore not be unwelcome. "Although very little is known of its author, there is no doubt that the Cæsar whom he addressed in his fulsome dedication was the Emperor 'Tiberius, and his main object was perhaps to provide a co!lection of apposite historical illustrations for use in the schools of rhetoric which sprang ip in such rank luxuriance in the early days of the Empire. Whether this was so or not, the work consists of a multitude of more or less edifying anecdotes, extracted from Livy, Cicero, Sallust, and a few other less familiar writers, and loosely strung together under subjects, those in which the characters are Romans being liept distinct from others relating to foreigners, which are relegated to the end of each section. There is no need to enter into details of the ninety-one chapters, under separate headings, which make up the nine books. Briefly, the first book deals with religiouss rites and ceremonies, the second with civil and military institutions, the third to the sixth with virtues and moral qualities. The contents of the remaining three books are much less homogeneous; but it is enough to say that, among a medley of other subjects, happiness is illustrated in the seventh book, public and private judgment in the eighth, luxury, avarice, and sundry other vices in the ninth. In spite of an affected and too rhetorical style, a collertion of stories of the kind could not fail to include abundant matter of interest."

We have adapted many of the foregoing remarks from Dr. Warner's Monograph on the Valerius Maximus Manuscript of Mr. Yates Thompson.

\section{ARETINUS (Leonardus).}

De Milicia ad Reynoldum Albitium.

MANUSCRIPT OF THE EARLY PART OF THE XVth CENTURY ON 2 I PAGES OF PAPER.

Small 4to, half calf.

(Italy, I42 I.)

$£ 4$ ss

An 18th century note in cover says: “Je doute que ce petit ouvrage ait êté imprimé: Du moins ne le trouve-t-on pas dans le catalogue des oeuvres de L. Aretin.", 


\section{HORA.}

Horæ Beatæ Mariæ Virginis, cum Kalendario.

BEAUTIFULLY AND RICHLY ILLUMINATED MANUSCRIPT ON

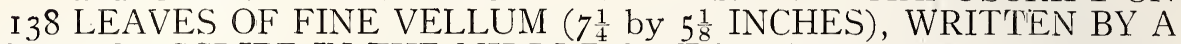
FRENCH SCRIBE IN THE MIDDLE OF THE FIFTEENTH CENTURY.

FINELY WRITTEN IN LARGE AND CLEAR GOTHIC CHARACTERS, I9 LONG LINES TO A FULL PAGE.

THE CALENDAR IS WRITTEN IN GOLD, RED AND BLUE, WITH RICH DECORATIVE INITIAL LETTERS AND FULL BORDERS. WITH TWO MINIATURES OF THE OCCUPATIONS OF THE MONTHS AND TWELVE MINIATURES ILLUSTRATIVE OF THE SIGNS OF THE ZODIAC.

WITH FIFTEEN FULL-PAGE MINIATURES, RICHLY PAINTED IN GOLD AND COLOURS AND I27 SMALLER MINIATURES ALSO PAINTED IN GOLD AND COLOURS. WITH A WIDE ORNAMENTAL ILLUMINATED BORDER TO EVERY PAGE OF TEXT, WITH MOTIFS OF ARABESQUES AND OVER 2,000 INITIAL LETTERS IN GOLD AND COLOURS.

8vo, blue morocco, doublé with red morocco, inside dentelles, g. e., by Trautz-Bauzonnet.

(France. About I4.4.)

(See Illustration, Plate No. XViI.).

$£ 450$

\section{SEDULIUS.}

\section{Paschale Carmen.}

A BEAUTIFULly WRITTEN MANUSCRIP'T OF THE XVth CENTURY, BY AN ITALIAN SCRIBE, ON VELLUM (8I pp.) WITH HEADINGS AND SIDE NO'TES IN RED.

8vo, handsomely bound in full pigskin, with blind tooled ornaments on the sides by the Guild of Women Binders.

Colophon at end reads "Finis Cantici : Sedulii poetae catholici pascalis carminis liber quartus et ultimus feliciter finit, Decimo Aprilis. MCCCCLV."

(Italy. I455).

Caelius Sedulius, a Roman poet and Christian of the 5th century, was the author nf "Mirabilia Divinorum," being portions of the history of the Bible in hexameter verse; a "Hymnus" in praise of Christ, and other similar works.

Early MSS. of his writings rarely come into the market. 


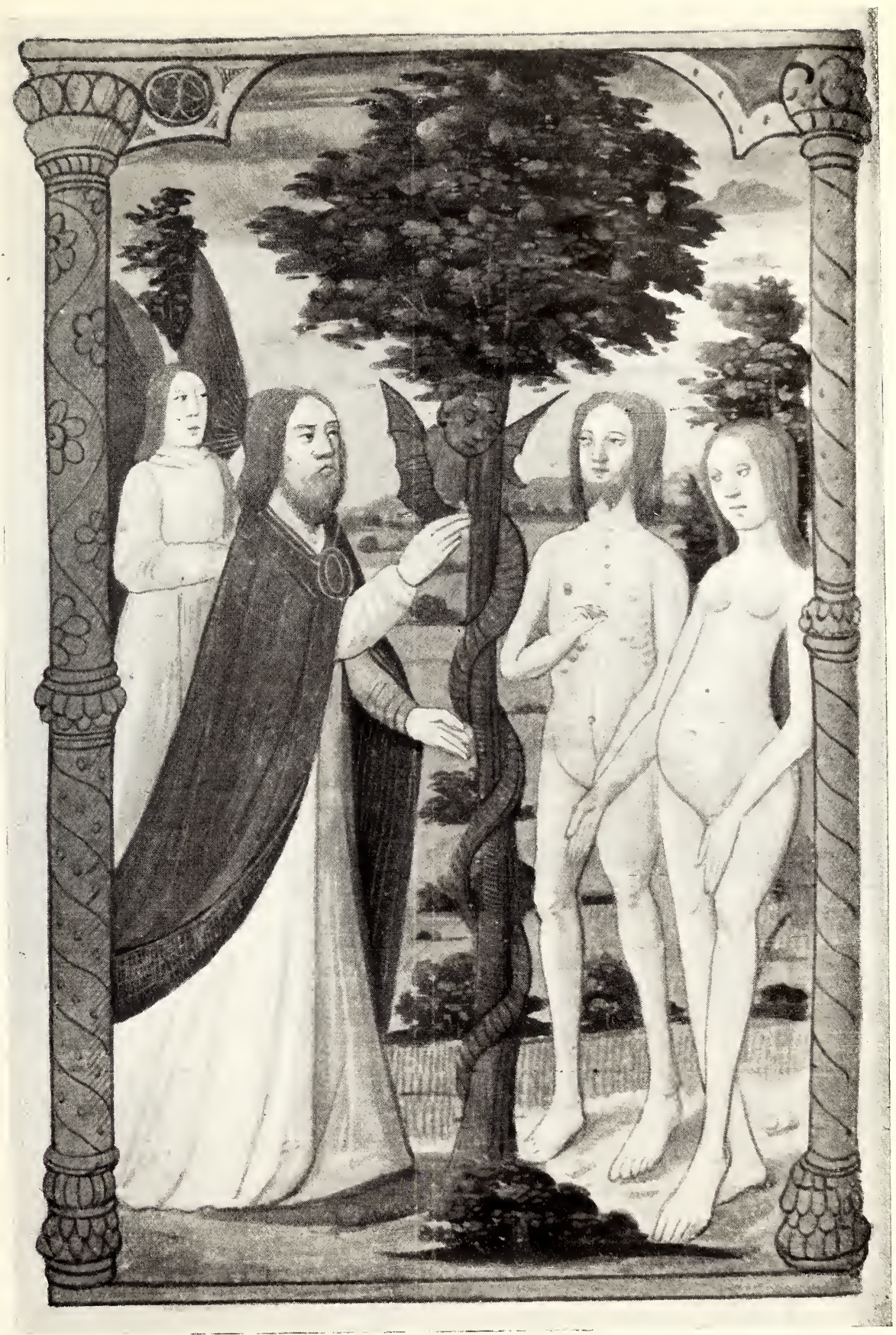

“Adam and Eve in Paradise" and "The 'Temptation" from Horae Beatae Mariae Virginis. Illuminated Book of Hont's on vellum written by a French scribe With 15 full-page and 127 smaller Miniatures. France, XVth Century. See Item No. 27. 


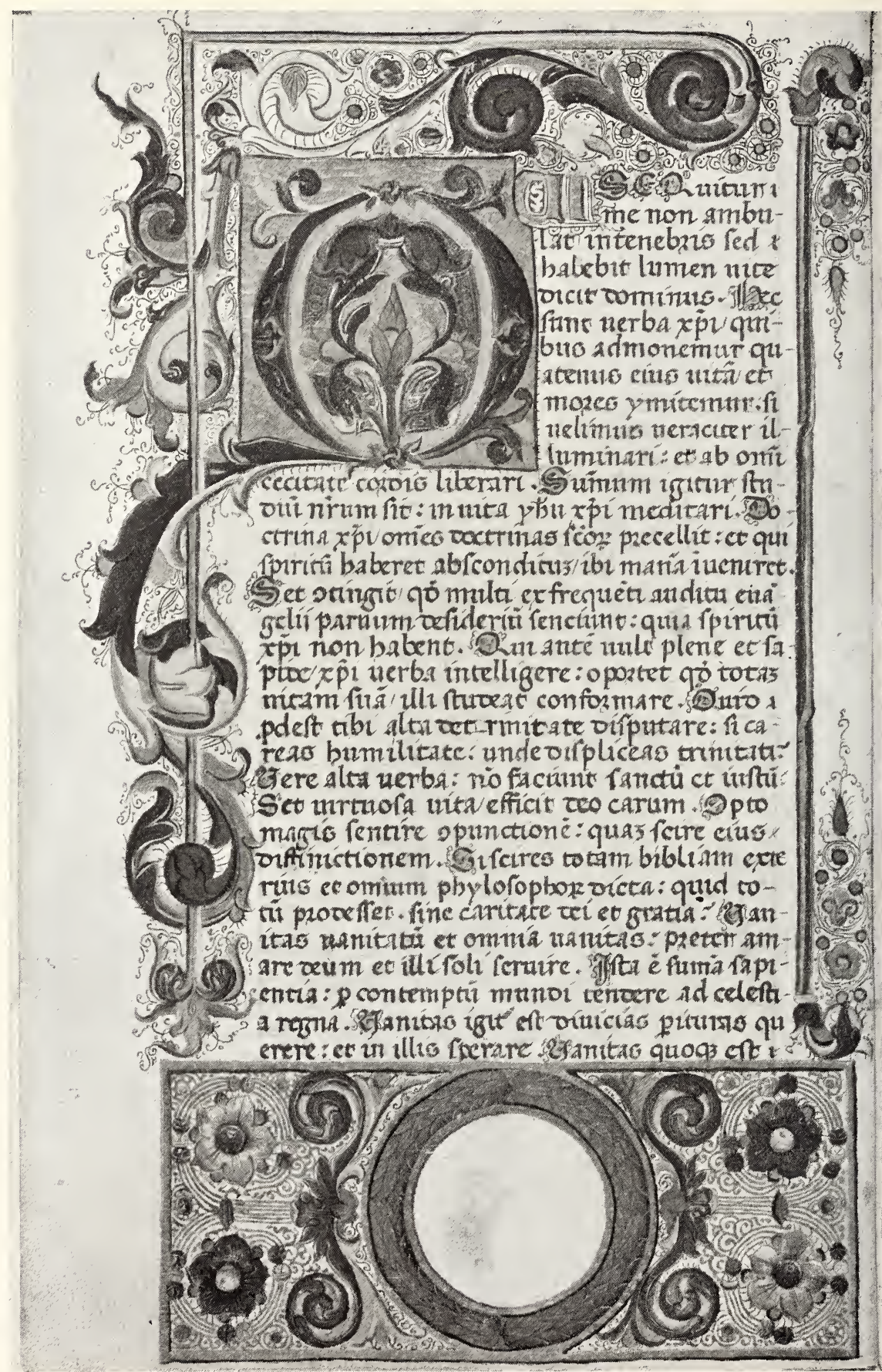

Opening page from Thomas a Kempis. Imitatio Christr.

MS. on vellum by a French scribe.

France, A.D. 1474.

See Item No. 30. 
29 AUGUSTINe (Saint).

\section{Confessiones.}

FINELY WRITTEN MANUSCRIPT OF THE XVth CENTURY. VELLUM.

GOTHIC LETTER, DOUBLE COLUMNS, ON I2I LEAVES OF

WITH LARGE ILLUMINATED MINIATURES IN TWO COMPARTMENTS. THE FIRST THE CONVERSION OF SAINT AUGUSTINE, THE SECOND AS SAINT AND BISHOP. ALSO 2 SMALL INITIAL MINIATURES AND I 5 LARGE CAPITALS IN RED, BLUE, AND GREEN, WITH PEN ORNAMENTATIONS.

Folio, full niger morocco gilt, with clasps, by Douglas Cockerell.

(Italy. XVth Century).

(See Illustration, Plate No. XVI.).

Illuminated Manuscript of the Imitatio Christi.

\section{THOMAS A KEMPIS.}

Imitatio Christi.

MANUSCRIPT IN LATIN WRITTEN BY A FRENCH SCRIBE ON 75 LEAVES OF VELLUM, FINELY WRITTEN IN SEMI-ROMAN LETTERS, 33 LONG LINES TO A PAGE, IN THE XVth CENTURY.

THE MARGINS OF THE REVERSE OF FIRST PAGE FINELY DECORATED WITH A LARGE ILLUMINATED INITIAL IN GOLD AND COLOURS, AND ELABORATE BORDER AND MARGINAL DECORATIONS IN GOLD AND COLOURS, THREE OTHER FINE LARGE INITIALS MAGNIFICENTLY ILLUMINATED WITH MARGINAL DECORATIONS.

Small folio, old Russia gilt, green silk linings.

(France. I474).

(See Illustration, Plate No. XVIII.).

$£ 185$

The manuscript starts with the words "incipit libellus compositus a domino Johane Gerseni Cancellario Parisiensi, De imitatione Christi.”

Magnificent and unusual manuscript of the Imitatio which is especially interesting owing to the fact that it attributes the authorship of the Imitatio to Gerson while the consensus of modern authorities has decided on the authorship of Thomas A’Kempis. 


\section{I CICERO.}

\section{Orationes Philippicae contra Marcum Antonium.}

BEAUTIFULLY AND CLEARLY WRITTEN MANUSCRIPT ON 192 LEAVES OF PAPER, 2 I LONG LINES TO A PAGE. WITH NUMEROUS NOTES IN THE MARGIN. WITH INITIAL LETTERS BEAUTIFULLY ILLUMINATED IN GOLD AND COLOURS, AND ON THE FRON'T PAGE BORDER AND INITIAL LETTER IN GOLD AND COLOURS AND A MINIATURE IN THE MARGIN OF CICERO CLO'THED IN A IONG, RED ROBE, WITH YELLOW CURLS AND GOLDEN BEARD, A LITTLE RED CAP ON HIS HEAD, ADDRESSING FOUR PERSONS, WHO ARE DRESSED RESPECTIVELY IN RED, BLUE, YELLOW, GREEN. AT THE FOO'T OF THE PAGE IS A COAT OF ARMS AND THE LETTERS V.C.

8vo, original binding of leather over oak boards, stamped in blind (repaired).

(Italy. I 480).

(See Illustration, Plate No. XIX.).

$£ 63$

At the end of manuscript is a note " 2 Octobris 1480 finit."

\section{OVIDIUS.}

\section{With the Scribe’s Name and Date.}

\section{Fastorum libri sex.}

MANUSCRIPT ON PAPER (90 11. I I $\frac{1}{4}$ by $7 \frac{1}{2}$ INCHES), VERY FINELY WRIT'TEN IN ROMAN LETTERS, LONG LINES, 29 TO A FULL PAGE.

(At end) " explicit feliciter per me Raphaelem DE PREDANIGRA incime Scte. Agathe Cremone MCCCCLXXXI. Die prime mensis marcii hora quarta et vigesima."

Small folio, calf.

(Cremona. I $448 \mathrm{I})$.

$£ 815 s$

** Manuscripts bearing the name and domicile of the Scribe and date are very uncommors.

Written for the Marco Dandolo, Doge of Venice.

33 LINO (Petrus Nicolas, of Vincenza).

\section{Dialogi ad Marco Dandolo Veneto.}

BEAUTIFULLY WRITTEN MANUSCRIPT ON PAPER IN A FINE ITALIAN HAND, WITH THE ARMS OF THE DOGE OF VENICE, MARCO DANDOLO, ILLUMINATED AT THE FOOT OF THE FIRST PAGE, AND A FINELY ILLUMINATED INITIAL LETTER AT THE BEGINNING OF THE WORK.

8vo, vellum.

(Venice. I 483).

$£ 3110 s$

Interesting manuscript by a medical man. 


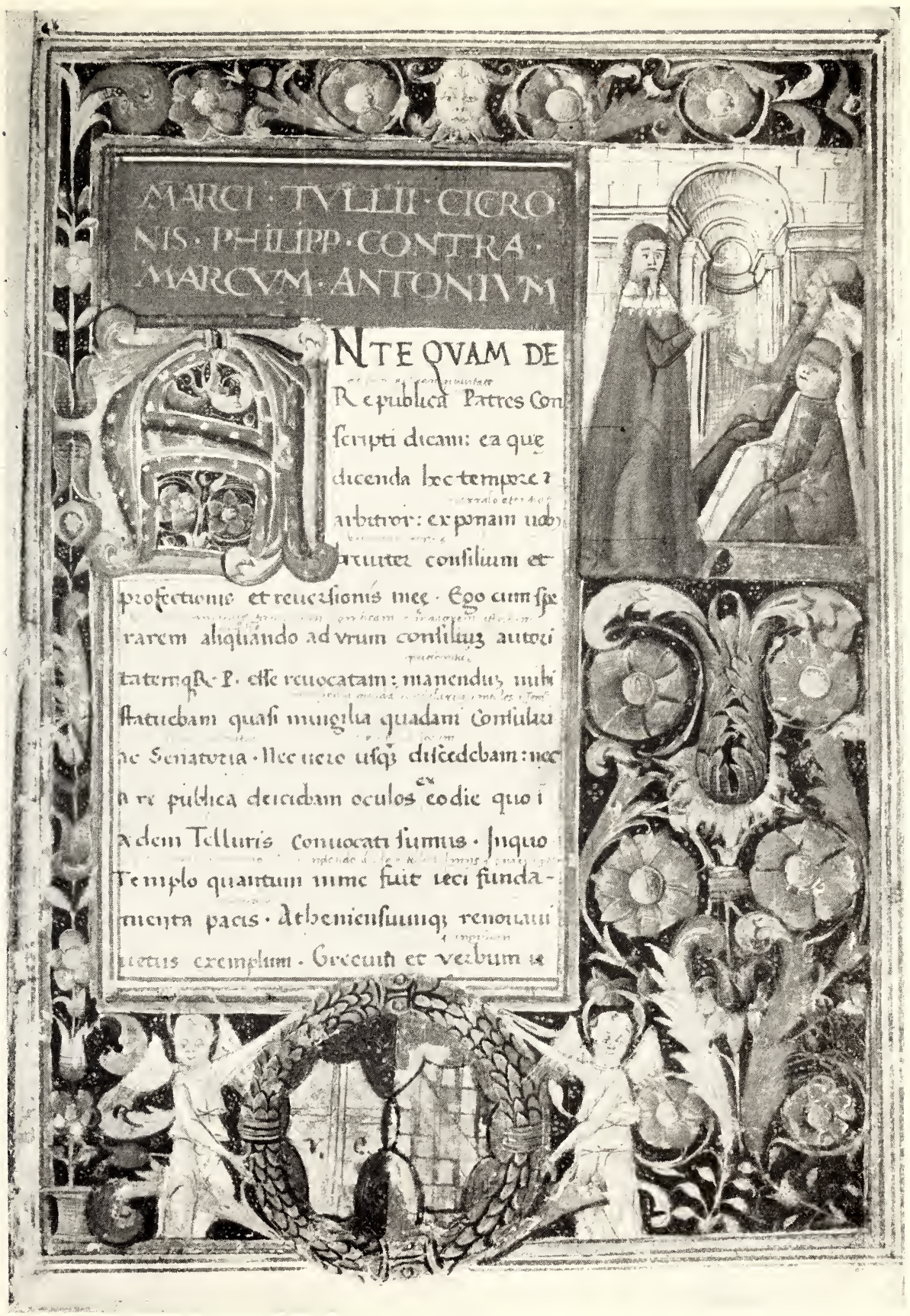

The opening page (reduced) from Cicero. Orationes Philippicae contra Mircu Al Antoniun. Latin Illuminated MS. on vellum, dated 1480 .

Italy, A.D. 1480 .

See Item No. 31. 


\section{Plate XX.}

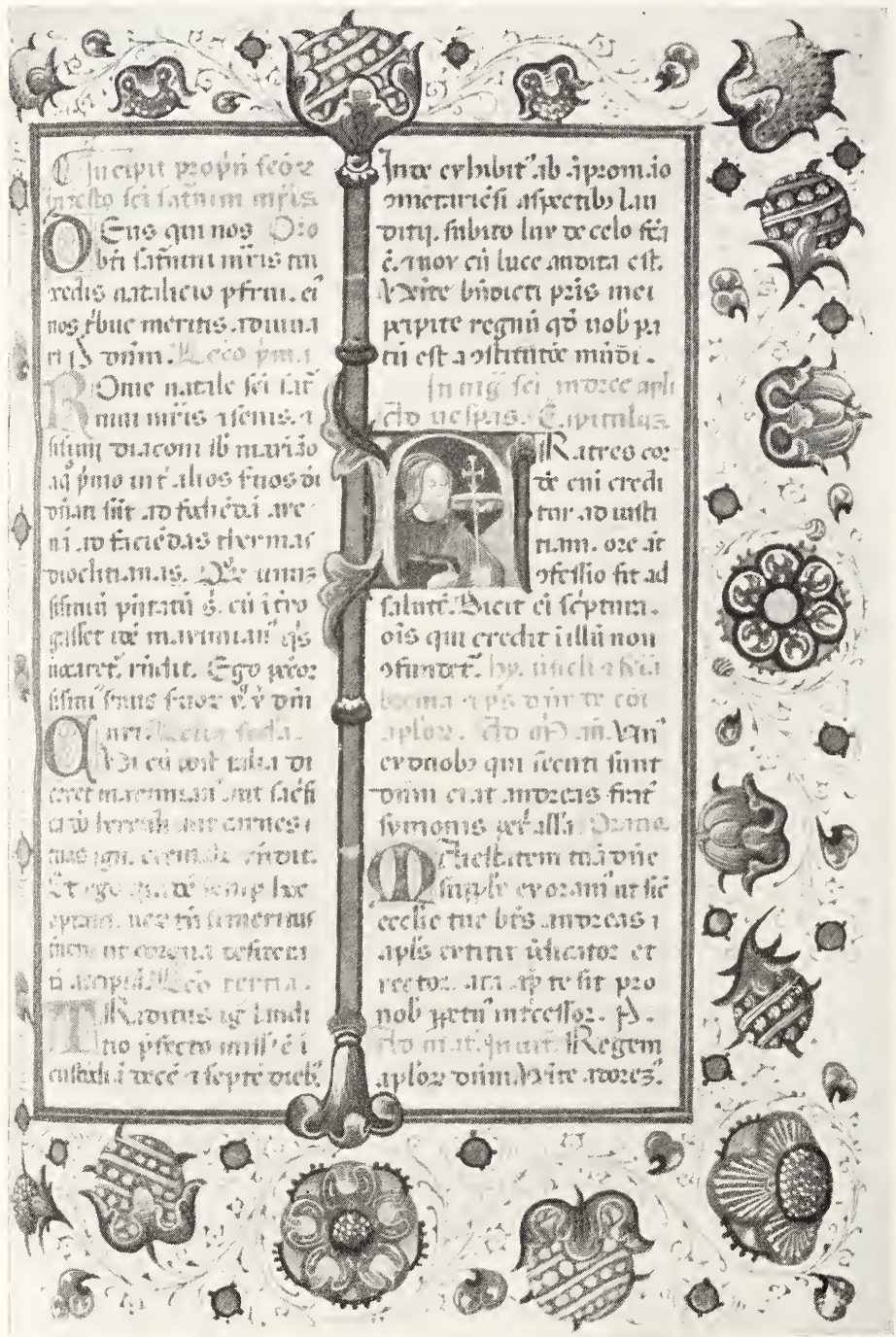

A page from Breviariun. Illuminated Breviary on vellum by an Italian scribe. With 42 historiated initials containing Miniatures.

Italy, XVth Century.

See Item No. 39. 


\section{With Date And Scribe's Name.}

\section{THOMAS A KEMPIS.}

Imitatio Christi [in German, translated by Johannes Zierer].

BEAUTIFULLY WRITTEN MANUSCRIPT IN GERMAN, IN GOTHIC LETTERS, 27 LONG LINES TO A FULL PAGE, ON PAPER, WITH RUBRICS AND CHAPTER-HEADINGS IN RED, SOME INITIALS IN RED.

Small folio, original XVth century binding of oak boards covered. with beautifully stamped leather.

(Strassburg. I485).

This German translation of the Imitatio of Kempis is interesting as it gives us not only the attribution to Thomas a Kempis himself, but it mentions the first translator into German, Father Johannes Zierer, in 1480, and the writer of this manuscript, Sister Katherina of the Convent of St. Mary Magdalene of the Strassburg Convent. with the date of her writing of the same in 1485 .

\section{With INSCRIPTION ANd Date.}

\section{MATUTINALE PREMONSTRATENSE.}

MANUSCRIPT ON VELLUM (FRENCH, XVth CENTURY). 334 LEAVES ( $7 \frac{3}{4}$ by $5 \frac{1}{8}$ INCHES), WRITTEN IN SMALL GOTHIC CHARACTERS, 3 I LONG LINES TO A PAGE.

ADORNED WITH SEVERAL LARGE ORNAMENTAL INITIALS IN GOLD AND COLOURS, SOME WITH FULL BORDERS OF ELABORATE PEN-DRAWN SCROLLS, GROTESQUE ANIMALS, ETC., THE FULL BORDERS ON THE' FIRST PAGE CONTAIN IN ADDITION SMALL FIGURES OF A RABBIT. FOX, UNICORN, LION AND STAG PAINTED IN GOLD, TWO GREYHOUNDS IN BROWN AND GREY WITH GILT COLLARS, AND TWO PEACOCKS IN BLUE, RED AND GOLD; OTHER LARGE INITIALS APPEAR IN RED AND BLUE WITH ELABORATE PEN-DECORATIONS, HUNDREDS OF SMALL CAPITALS PAIN'TED IN BLUE OR RED.

Thick 8vo, old calf, gilt device on both covers of lily of the valley sprays, surrounded by the inscription "Bibliothecae Parchensis."

(Belgium. I 499).

** This Manuscript contains the Offices and Services of the Breviary for Matins only, except the hymnary which gives the hymns for respers and compline.

Written for a house of cannonesses probably affiliated to the Abbey of Pare, near Louvain, by the hand (Propriis manibus) of the Prioress, as appears from an inscription towards the end of the rolume.

"Mera ex caritate. Festiuis diebus (racanti) tempore liber his scriptum exstat, quare vendi non licet, sed pie exorandum pro Adriana van den veeken tunc temporis priorissa, que suis laboribus indefiessis propriis manibus eundem perfecit. Anno milleno quadringenteno nonagintesimo nono, duodecima die mensis augusti." 
MAGGS BROS., 34 \& 35, Conduit Street, London, W.

With Name of the SCRIBe.

36 Auqustine (Saint).

\section{Opuscula quaedam.}

De Predestinatione sanctorum; de bono Perseverantiae; de Vita beata; de Virginitate; de Virginitate B.V.M.; de Continentia et Patientia; de Natura Rerum, etc.

MANUSCRIPT ( $8 \frac{1}{2}$ by $5 \frac{1}{2}$ INCHES), WRITTEN BY A SOUTHITALIAN SCRIBE IN NEAT SEMI-ROMAN LETTERS, ON I6́ LEAVES OF VELLUM, 28 LONG LINES TO A FULL PAGE, WITH CATCHWORDS.

ADORNED WITH I2 FINELY-PAINTED AND ILLUMINATED ORNAMENTAL INI'TIALS.

Small 4to, old velium.

(South Italy. XVth Century).

$£ 14145$

On the reverse of page 40 occurs the name of the Scribe "Scriptum p. Fr. Ambrosium Mölbergensz. prentie Misensium" (in Campania), and another inscription at end.

\section{BIBLE.}

\section{Greek Manuscript of the New Testament.}

\section{Biblia Graeca.}

MANUSCRIPT OF THE GREEK NEW TESTAMENT WRITTEN IN A NEAT HAND ON PAPER, IN THE XVth CENTURY.

4to, handsomely bound in red silk, with silver embroidery on sides and with silver device of the Crucifixion in front and of the Trinity at back, back decorated with silver embroidery, $g$. e., silver clasps, one missing.

(Italy. XVth Century).

$£ 45$

38 BURLEY (Walter).

De philosophorum vita et moribus e Graeco in Latinum traducta.

MANUSCRIPT ON I74 LEAVES OF PAPER (XVth CENTURY), WRITTEN IN NEAT SEMI-GOTHIC LETTERS, 22 LONG LINES TO A FULL PAGE, THE FIRST PAGE HAVING A FINELY PAINTED AND ILLUMINATED BORDER OF FLOWERS AND A NUDE FIGURE, WITH LARGE ILLUMINATED MINIATURE INITIAL OF A PHILOSOPHER, A HEAD OF A PHILOSOPHER AT EACH CORNER, ANOTHER ILLUMINATED DECORATIVE INITIAL, AND THE EMBLAZONED COAT-OF-ARMS OF AN ABBOT.

Small 4to, modern morocco extra, inside dentelles, g. e., by Aitkin. (Italy. XVth Century).

-(See Illustration, Plate No. XXI.). 


\section{Plate XXI.}

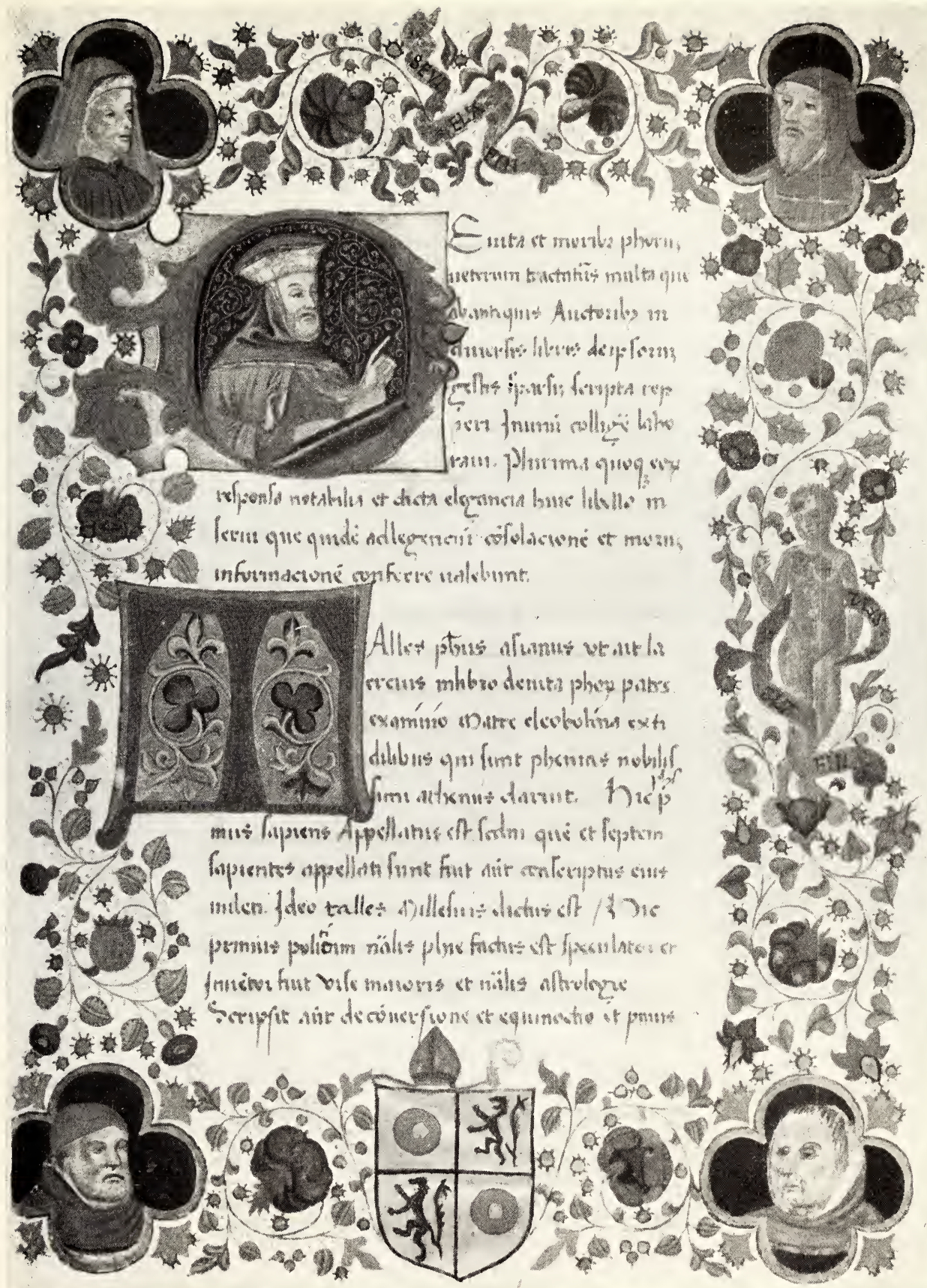

Opening page from Walter Burley. De Philosophordi Vits.

Illuminated MS. on paper by an Italian scribe.

Italy, XVth Century.

See Item No. 38. 
a

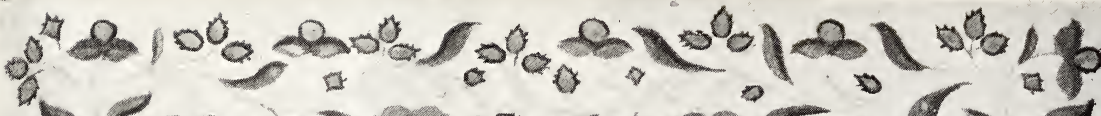

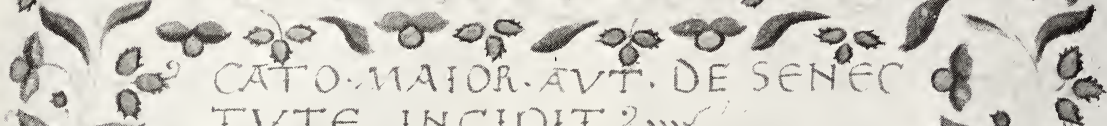
a 10 TVTE. HNCAPHF:…

- STDCORTIEE.SA.QVIDEGOAD

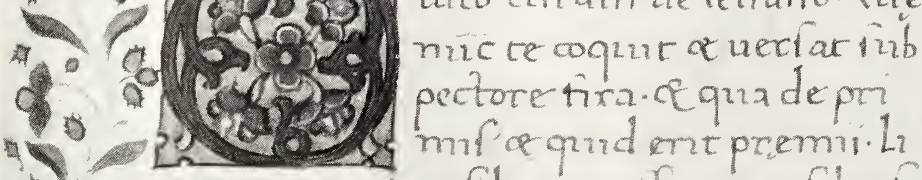
- ceternm mibrifdem te afforn uechibrí - Partice quibuf affanar formmañlle un * baud magna ar refó plemur fíder qua

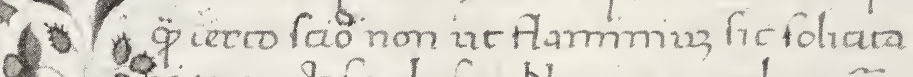

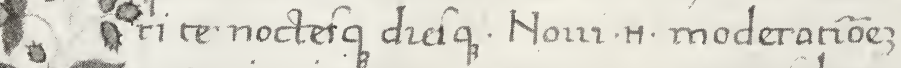
- mimitario equzrratem reg non folim D = p cognoméabemídeportalle fed bumati o. Orufpicor uidem rebrif́téquaru merips - confolotio a maror eff cem alind temp?

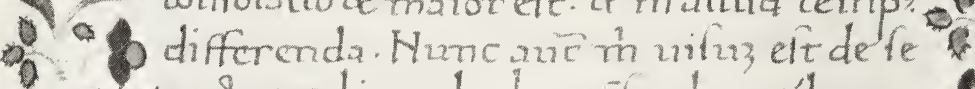
- Recture alionend ad te colponbece hor H.

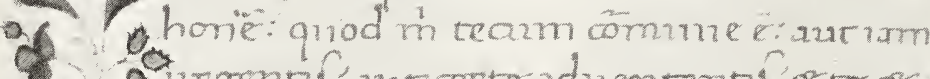

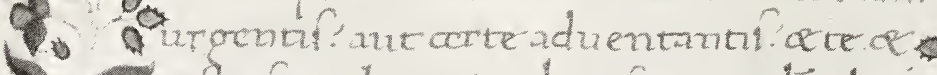

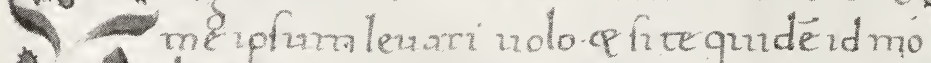

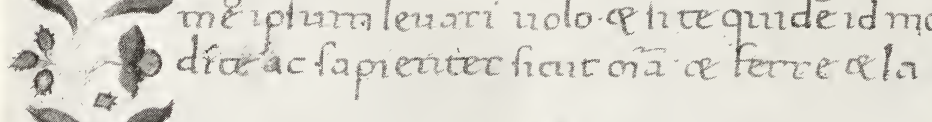

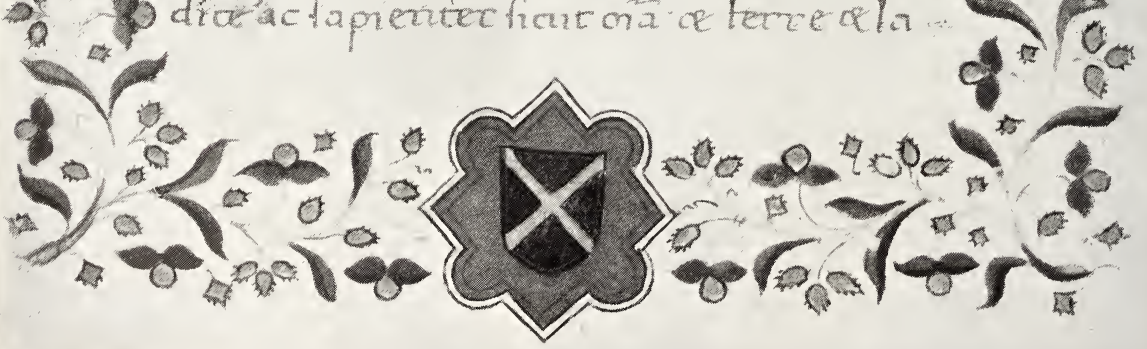

The opening page from Cicero. De Senectute. De Amicitia. Paradoxa. Manuscript on 72 leaves of vellum with the Arms of the Abbey of St. Albans (Hertfordshire), England. England, XVth Century. See Item No. 41. 
MAGGS BROS., 34 \& 35, Conduit Street, London, W.

\section{BREVIARIUM.}

\section{Breviarium monarchorum heremitarum sancti Antonii secundum consuetudinem Romanae curiae.}

ILLUMINATED MANUSCRIPT WRITTEN ON 4I 7 LEAVES OF VELLUM ( $5 \frac{1}{2}$ by $4 \frac{1}{2}$ INCHES), BY AN ITALIAN SCRIBE IN THE MIDDLE OF THE XVth CENTURY, DOUBLE COLUMNS, 30 LINES TO A COLUMN, NEATLY WRITTEN IN A PRETTY GOTHIC HAND, CALENDAR IN RED AND BLACK.

THREE PAGES ARE SURROUNDED BY FULLY ILLUMINATED BORDERS WITH FLORAL DECORATIONS FINELY PAINTED IN GOLD AND COLOURS, THE FIRST HAVING A SPACE FOR A COAT OF ARMS UPHELD BY TWO AMORINI, WITH 42 HISTORIATED INITIALS, WITH DELICATELY PAINTED MINIATURES REPRESENTING VARIOUS EVENTS IN THE LIVES OF JESUS AND THE VIRGIN MARY, MANY WITH MARGINAL ELONGATIONS OF BAR WORK, WITH FLORAL TERMINATIONS. AND MANY OTHER INITIALS IN BLUE AND RED IN DELICATE PEN ORNAMENTATIONS.

$$
\begin{aligned}
& \text { I } 2 \text { mo, oid red velvet, g. e. } \\
& \text { (Italy. XVth Century). } \\
& \text { (See Illustration, Plate No. XX.). }
\end{aligned}
$$

In excellent preservation.

\section{Cicero.}

\section{De officiis, Paradoxa, De Amicitia, de Senectute.}

BEAUTIFULLY WRITTEN MANUSCRIPT, VERY LEGIBLY CARRIED OU'T ON 2 I8 LEAVES OF VELLUM, 2I LONG LINES TO A FULL PAGE. THE FIRST PAGE IS DECORA'TED WITH A FLOREATED BORDER IN GOLD AND COLOURS WITH A MINIATURE OF CICERO DRESSED IN GREEN STANDING AT A READING DESK, ADDRESSING A SEATED FIGURE, DRESSED IN BLUE, WITHIN A FRAMEWORK OF GROTESQUE ANIMALS, AT THE FOO'i' OF PAGE AN ESCUTCHEON. SMALLER FLOREATED BORDERS IN GOLD AND COLOURS AT THE OPENING OF EACH BOOK AND NUMEROUS INITIALS ILLUMINATED IN BLUE AND RED HEIGH'TENED IN GOLD THROUGHOU'T THE MANUSCRIP'T.

Small 8vo, calf gilt, $g$. $e$.

(Italy. XVth Century).

A very neat manuscript in excellent preservation and very legible. 
MAGGS BROS., 34 \& 35, Conduit Street, London, W.

4I CICERO.

\section{De Senectute. De Amicitia. Paradioxa.}

BEAUTIFULLY WRITTEN MANUSCRIPT ON VELLUM (72 LEAVES), 24 LONG LINES TO A PAGE, ON THE FIRST PAGE THERE IS A PAINTED BORDER OF FOLIAGE, HEIGHTENED WITH GOLD, CONTAINING THE ARMS OF THE ABBEY OF ST. ALBANS (HERTFORDSHIRE), WITH MANY OTHER INITIALS ILLUMINATED IN GOLD AND COLOURS.

Small 4to, russia gilt.

(England. XVth Century).

(See Illustration, Plate No. XXiI.).

$£ 63$

42 CICERO.

De Officiis.

BEAUTIFULLY AND NEATLY WRITTEN MANUSCRIPT ON 89 LEAVES OF VELLUM, 25 LONG LINES TO A FULL PAGE.

ON THE FIRST PAGE IS AN ILLUMINATED INITIAL PAINTED IN BLUE AND GOLD ENCLOSING THE MINIATURE OF CICERO CONVERSING.

4.to, vellum gilt.

(Italy. XVth Century).

$£ 35$

4.3 CICERO.

\section{Tusculanae quaestiones.}

BEAUTIFULLY WRITTEN MANUSCRIPT BY AN ITALIAN SCRIBE OF THE XVth CEN'TURY ON VELLUM ( 8 by $5 \frac{1}{2}$ INCHES), NEATLY WRITTEN IN ROMAN LETTER ON I 28 LEAVES OF VELLUM, 24 LONG LINES TO A FULL PAGE. WITH 7 INITIALS IN GOLD AND COLOURS. THE FIRST BEAUTIFULLY DECORATED WITH WHITE LINE MARGINAL DESIGN. edges.

8vo, green morocco, gilt, broad inside borders, leather joints, gilt

(Italy. XVth Century).

$£ 3110$ s

44 CICERO.

\section{De Officiis.}

BEAUTIFULLY WRITTEN MANUSCRIPT ON I69 LEAVES OF VELLUM, 25 LONG LINES TO A FULL PAGE.

4to, red morocco gilt, gold fillet line borders on sides, fully gilt back, inside dentelles, $g$. e.

(Italy. XVth Century). 
Plate XXIII.

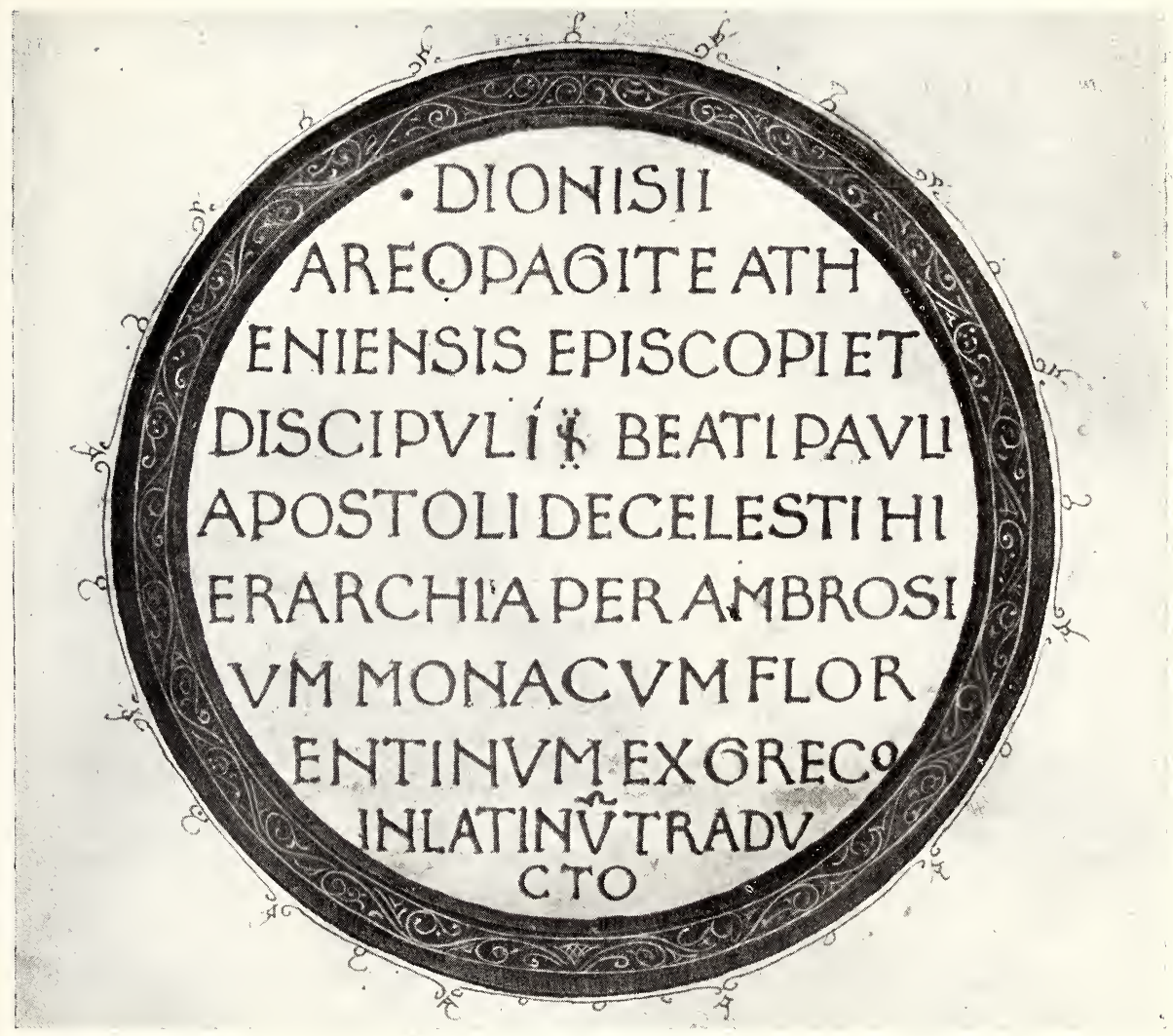

Title (reduced) superbly Illuminated in letters of gold with border of green and gold from Dionysius, De HiERarchia.

Illuminated on vellum.

Italy, XVth Century.

See Item No. 46. 


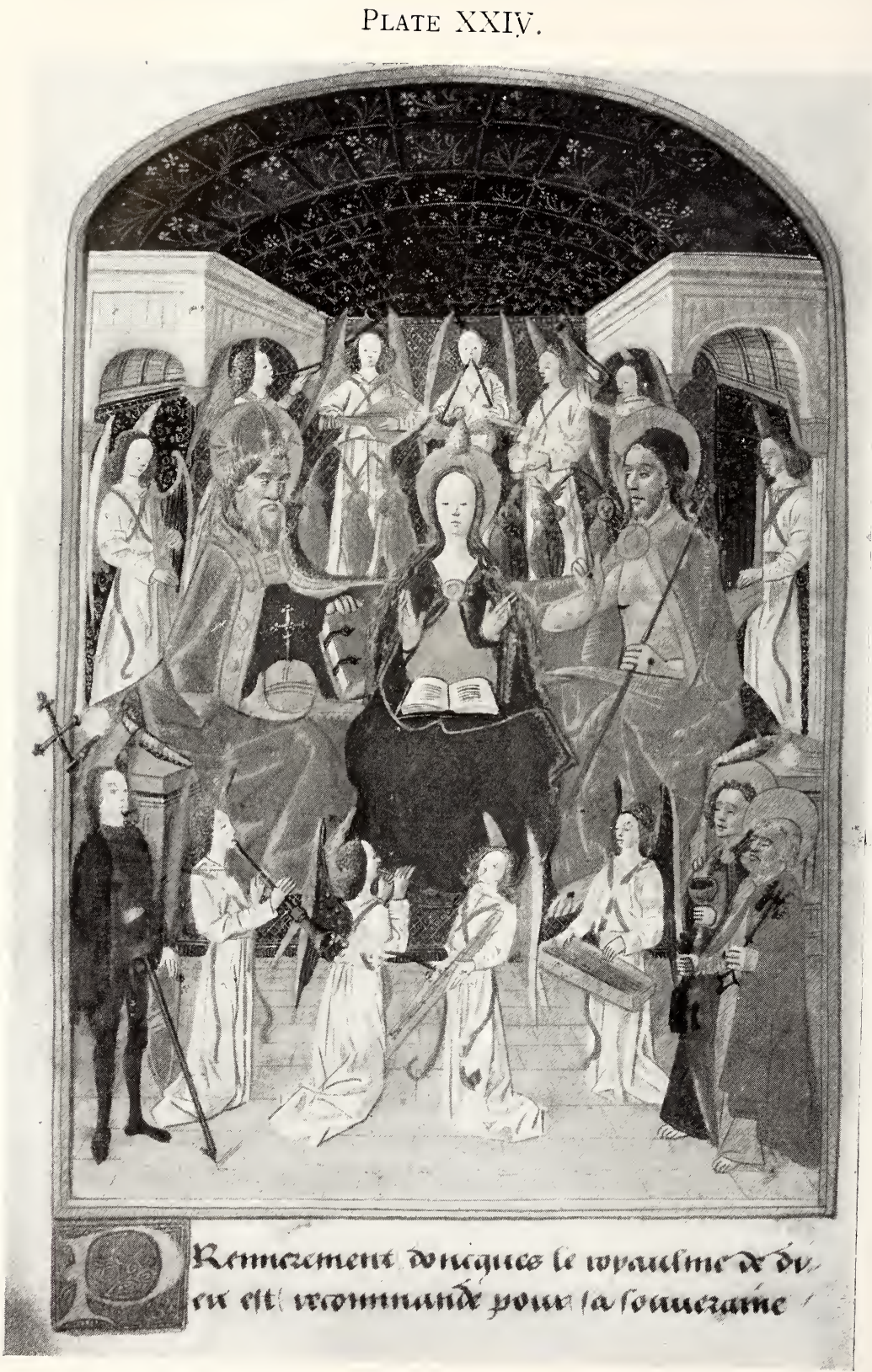

The Miniature of " Heaven" from “ Le Cordial." Illuminated MS. in French on vellum. France, XVth Century. See Item No. 45. 
MAGGS BROS., 34 \& 35, Conduit Street, London, W.

With Miniatures of Heaven and Hell.

45 CORDIAL (Le).

\section{MANUSCRIPT WRITTEN BY A FRENCH SCRIBE IN FRENCH ON VELLUM.}

DIVIDED INTO FOUR PARTS, THE FIRST TREATS OF CORPORAL DEATH, THE SECOND OF THE LAST JUDGMENT, THE THIRD OF ETERNAL HELL, AND 'THE FOURTH OF' 'THE JOYS OF' PARADISE.

WITH TWO MINIATURES, ONE OF HEAVEN, AND THE OTHER OF HELL.

THE MINIATURE OF HEAVEN REMINDS ONE VERY MUCH OF PAINTINGS BY BOTTICELLI AND THE EARLY ITALIAN SCHOOL.

THE MINIATURE OF HELL, IN WHICH THE PRINCE OF DARKNESS IS SEEN CONSIGNING GROUPS OF UNHAPPY VICTIMS TO THE JAWS OF THE DEVOURING MONSTER, IS IN THE STYYLE ADOPTED BY BLAKE.

4to, full levant morocco, inside gold dentelles, giilt ed ges, by Petit, successeur de Simier (a few pages missing).

(France. XVth Century).

(See Illustration, Plate No. XXiV.).

$£ 120$

Beautifully Written.

46 "DIONYSIUS AREOPAGITICUS ATHENIENSIS EPISCOPUS."

De Celesti Hierarchia (et alia Opuscula). Per Ambrosium (Camuldulensium) Monachum Florentinum Ex Greco in Latinum Traducto."

MANUSCRIPT ON I 20 LEAVES OF VELLUM (ITALIAN, XVti CENTURY) (I I by $7 \frac{1}{2}$ INCHES).

FINELY WRITTEN IN SEMI-ROMAN LETTERS, 32 LONG LINES TO A FULL PAGE, BY AN ITALIAN SCRIBE, WITH MARGINAL NO'TES IN A LATER HAND, RED RUBRICS.

THE TITLE AS ABOVE WRITTEN IN GOLD LETTERS WITHIN A CIRCLE WITH A BORDER OF GREEN AND GOLD, THE FIRST PAGE DECORATED WITH A THREE-QUARTER BORDER OF FLOREATE SCROLLS IN WHITE, BLUE, RED AND GOLD, WITH AN INITIAL, MANY ILLUMINATED DECORATIVE INITIALS.

Small folio, citron morocco super-extra blind and gold tooled to a beautiful XVth century Italian pattern, g. e., by Leighton.

(Italy. XVth Century).

(See Illustration, Plate No. XXili.).

$£ 105$

** A FINELT WRITTEN AND DECORATED MS. in perfect state. On verso of first leaf is a list of the writings of the Author contained in the MS. At the end of the treatise De Mystica Theologia in an inscription "Absolui ambrosius peccator dyonisii opuscula in monasterio fontis boni xv. Kal. Aprilis Anno doninice incarnationis m, cecexxxvi." Ete. 


\section{CICERO.}

De Amicitia, Senectute, and Paradoxa.

NEATLY WRITTEN MANUSCRIPT ON I 53 LEAVES OF VELLUM BY AN I'TALIAN SCRIBE, I 7 LONG LINES TO A PAGE, WIT'Í INITIALS PAINTED IN COLOURS AND THE HEADINGS IN RED (THE MARGINS OF A FEW LEAVES REPAIRED AND SOME MARGINS STAINED).

Svo, vellum, $g$. e.

(Italy. XVth Century).

$£ 1010 \mathrm{~s}$

\section{EUSEBIUS PAMPHILUS.}

De Evangelica Praeparatione Latinum ex Graeco traducta per Georgium Trapezuntium.

MANUSCRIPT ON 3I4 LEAVES OF VELLUM OF THE XVth CENTURY (I I by $8 \frac{1}{2}$ INCHES), FINELY WRITTEN IN ROMAN LETTERS BY AN ITALIAN SCRIBE, LONG LINES, 26 TO A PAGE, WITH CONTEMPORARY MARGINAL NOTES AND HEADINGS Or̈ BOOKS IN RED AND CATCHWORDS.

THE FIRST PAGE FINELY ILLUMINATED WITH AN ORNAMENTAL BORDER CON'TAINING THREE PARROTS AND A PEACOCK, A FINE INITIAL OF INVOLVED RIBBON SCROLLS AND COAT-OF-ARMS BELOW (GULES, A CHEVRON BETWEEN 3 CUPS, OR), AND AN ILLUMINATED INITIAL TO EACH BOOK.

Small folio, contemporary oaken boards, leather, stamped in panels of dotted interlaced scrolls and pellets, some in gold and red, io metal bosses, gilt and gauffred edges, and side and front clasp-catches! (nere back).

(Italy. XVth Century).

(See Illustration, Plate No. XXV.).

$£ 85$

$A$ very fine and perfect MS. in most excellent condition.

\section{EUTROPIUS.}

\section{De Gestis Romanorum.}

NEATLY WRITTEN MANUSCRIPT BY AN ITALIAN HAND OF THE ITALIAN RENAISSANCE PERIOD, ON I44 LEAVES OF VELLUM, 2O LONG LINES TO A PAGE.

FINELY PAINTED INITIAL LETTER, ILLUMINATED IN GOLD AND COLOUR EXTENDING THE LENGTH OF THE TEXT. OTHER INITIALS IN RED AND BLUE. MANUSCRIPT NOTES IN THE MARGINS. bosses.

8vo, early binding of oak boards covered with leather and metal

(Italy. XVth Century.)

$£ 42$

The Eutropius has been continued by Paulus Diaconus. 


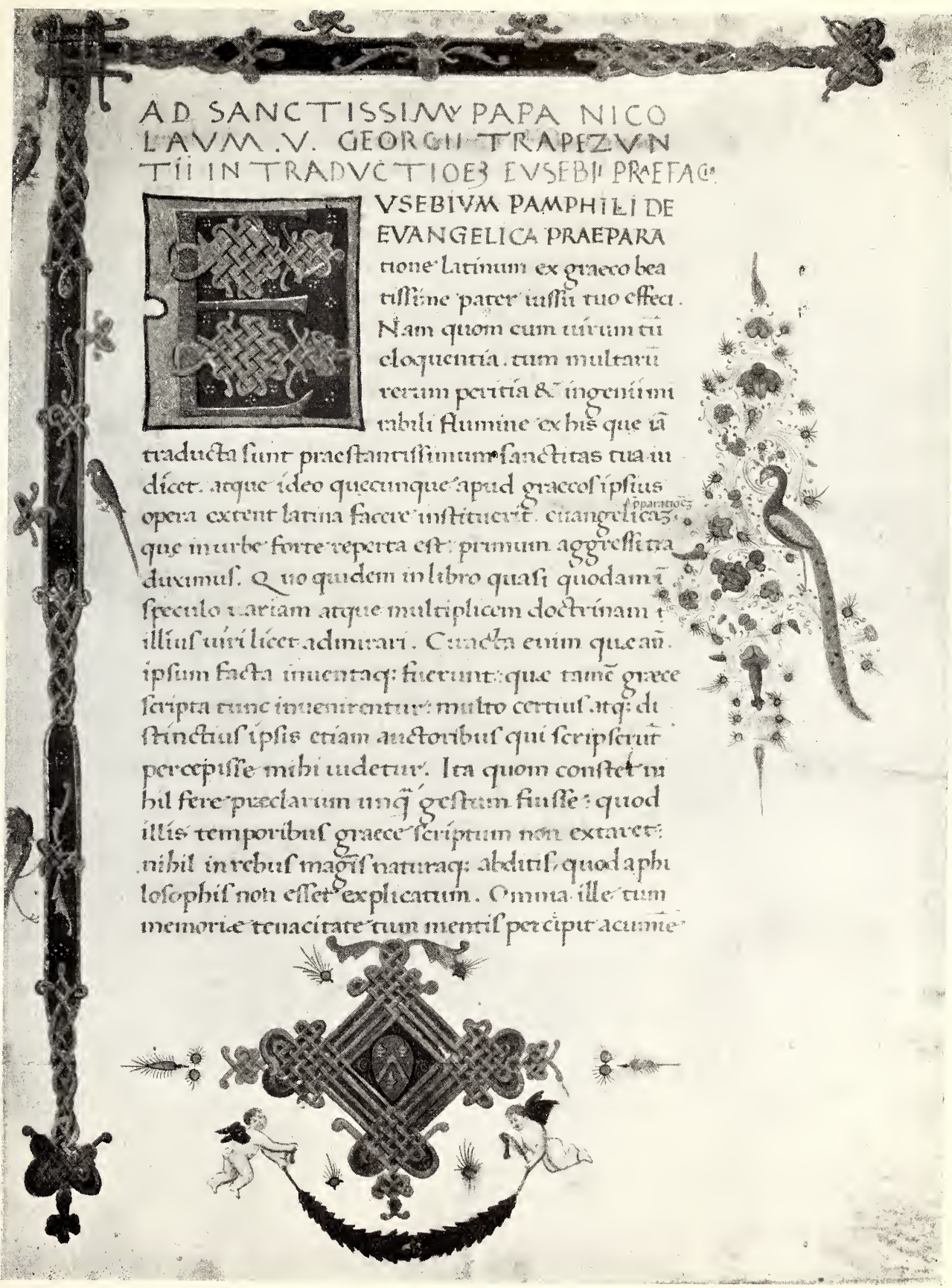

Opening Page from Eusebius Payphilus. Je Evasgelica Preparatione. Italy, XVth Century. See Item No. 48. 
Plate XXVI.

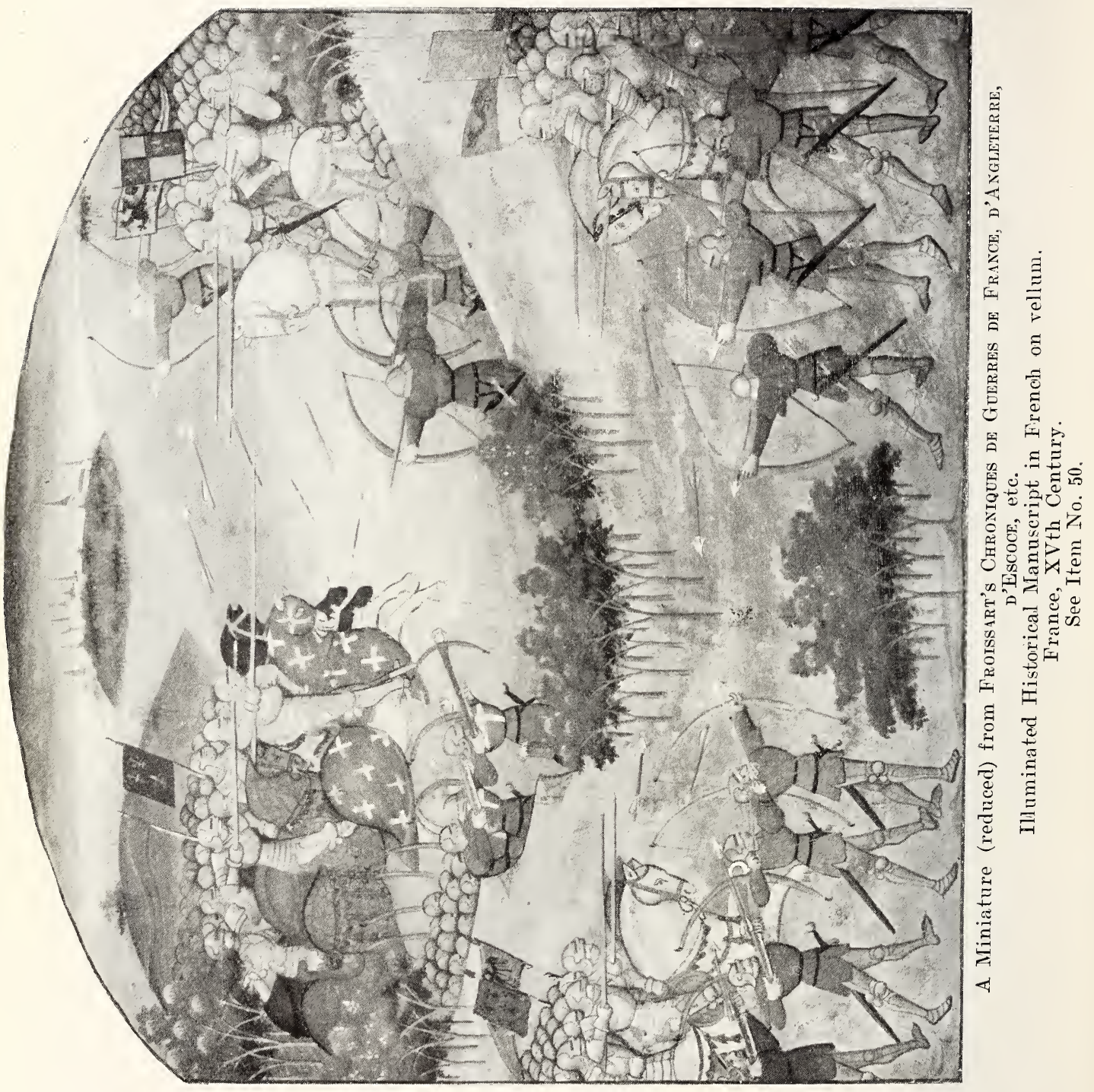


MAGGS BROS., 34 \& 35, Conduit Street, London, W.

A Splendid Example of French Calligraphy and the Miniaturist's Art. The Condition throughout is Excellent.

The Illuminated Chronicles of the Wars of England and France.

50 FROISSART (Jehan).

CHRONIQUES, “ CY COMMENCENT LES CRONIQUES DE SIRE JEHAN FROISSART CONTENANT LES NOUVELLES GUERRES DE FRANCE, D'ANGLETERRE, D'ESCOCE, D'ESPAIGNE, D'ALEMAIGNE, E'T DE BRETAIGNE."

ILLUMINATED MANUSCRIPT ON VELLUM [FRENCH, XVtin CENT.], 384 LEAVES ( $16 \frac{1}{2}$ by II $\frac{1}{2}$ INCHES), WRITTEN IN BOLD LETTRES BATARDES, IN DOUBLE COLUMNS, 53 LINES TO A PAGE, CHAPTER HEADINGS WRITTEN IN RED.

THE FIRST PAGE HAS A MAGNIFICENT LARGE ARCHED MINIATURE ( $6 \frac{1}{2}$ by $7 \frac{1}{1}$ INCHES), VERY FINELY PAINTED IN GOLD AND COLOURS, DEPICTING TWO BATTLES, PROBABLY, JUDGING BY THE BANNERS CARRIED BY THE OPPOSING ARMIES, THOSE OF CRECY, 26 AUGUST, I 346, AND NEVILLE'S CROSS, I 7 OCT. I 340. IN WHICH MOUNTED KNIGHTS IN ARMOUR AND ARMOURED ARCHERS AND ARQUEBUSIERS ARE TAKING PART; LARGE ORNAMENTAL INITIAL BELOW WITH ELONGATIONS OF STRAPWORK AND BORDERS COMPOSED OF FLOWERS AND SCROLLS, PEN TENDRILS AND GILT IVY LEAVES; AT FOOT IS A COAT-OFARMS EMBLAZONED.

TWO OTHER FINELY EXECUTED MINIATURES ( $3 \frac{1}{2}$ by 3 INCHES) OCCUR IN THE VOLUME. ONE DEPICTING MOUNTED KNIGH'TS IN ARMOUR PROCEEDING TOWARDS A CASTLE, THE OTHER SHOWS THE FUNERAL PROCESSION OF A KING.

NUMEROUS CAPITALS PAINTED IN BURNISHED GOLD ON COLOURED GROUNDS.

Thick folio, old binding of oak boards covered brown velvet, sheepskin back, five large brass protective bosses on each cover.

(France. Early XVth Century.)

(See Illustration, Plate No. XXVi.).

$£ 650$

This Manuscript describes the stirring events and battles between England, France, and Scotland from 1326 to the year 1379.

This period includes the time of Froissart's Journey to England, when one may readily suppose he had discontinued the work, for he considered it then as being finished, since he says he carried it to England, where he presented it to the Queen.

Jean Froissart was born at Valenciennes in 1337. He was educated for the church; but his love of festive pleasure and romantic gallantry directed him into other pursuits. At the age of twenty he began to write chronicles of the wars of his time and to obtain the requisite information he travelled much, and associated with the nobles and principal actors in public affairs. In the year 1361 he visited the court of Edward III. of England, where he remained five or six years and was treated with great favour, especially by the Queen Philippa, who employed him as her clerk or

(Continued over) 
Froissart (Jehan)-continued.

secretary. He attended Lionel, Duke of Clarence, when he went to Italy to marry the daughter of the Duke of Mlilan. After the death of Phillipa, in 1369, he officiated a short time as curate of Lestines, in France. About the year 1385, Guy, Count of Blois, employed Froissart as clerk, and the latter. soon afterwards, in quest of historical materials; visited Gaston, Count of Foix. His active curiosity, even in his declining years, led him to frequent courts, festivals, and tournaments, and his Chronicles present a " faithful mirror of the age of chivalry, with its beauties and deformities." He is esteemed for his veracity, and admired for picturesque description and a charming simplicity of expression.

\section{I HORACE. Opera.}

Virgil. Bucolica and Georgica.

Persius. Satires.

statius. Thebaid.

INTERESTING MANUSCRIPT IN LATIN WRITTEN ON 2 I 8 LEAVES OF VELLUM, 29 LONG LINES TO A PAGE, INITIALS IN RED, RUBRICATED.

8vo, Medici binding of leather over oak boards, blind tooled. (Italy. Early XVth Century.)

An early manuscript full of variants. The Horace only wants 16 lines to make the text quite perfect. At the end of the Statius there are four lines not found in any of the printed editions. At the end are a few pages of poetical matter, some written on palimpsest leaves

\section{IA HORAE BEATAE MARIAE VIRGINIS, cum Kalendario.}

WRITTEN ON I 4 I LEAVES OF VELLUM, BY A FRENCH SCRIBE, WITH HUNDREDS OF SMALL INITIAL LET'TERS BEAUTIFULLY ILLUMINATED IN GOLD AND COLOURS, EVERY PAGE BEARING A BORDER ILLUMINATED IN GOLD AND COLOURS USUALLY OF A FLORAL CHARAC'TER.

WITH IO FULL-PAGE FINELY ILLUMINATED MINIATURES WITHIN A BORDER OF A FLORAL NATURE IN GOLD AND COLOURS.

$8 \mathrm{vo}$, bound in remarkable XVIth Century binding of brown calf, the sides entirely covered with floral and foliated ornaments by Nicolas Eve (back slightly repaired), $g$. e.

(France. About I 520).

The Miniatures are as follows:-

1. The Annunciation.

2. The Nativity.

3. The Annunciation to the Shepherds.

4. The Adoration of the Magi.

5. The Circumcision.
6. The Flight into Egypt.

7. The Coronation of the Virgin.

8. King David the Psalmist.

9. The Crucifixion.

10. Pentecost. 


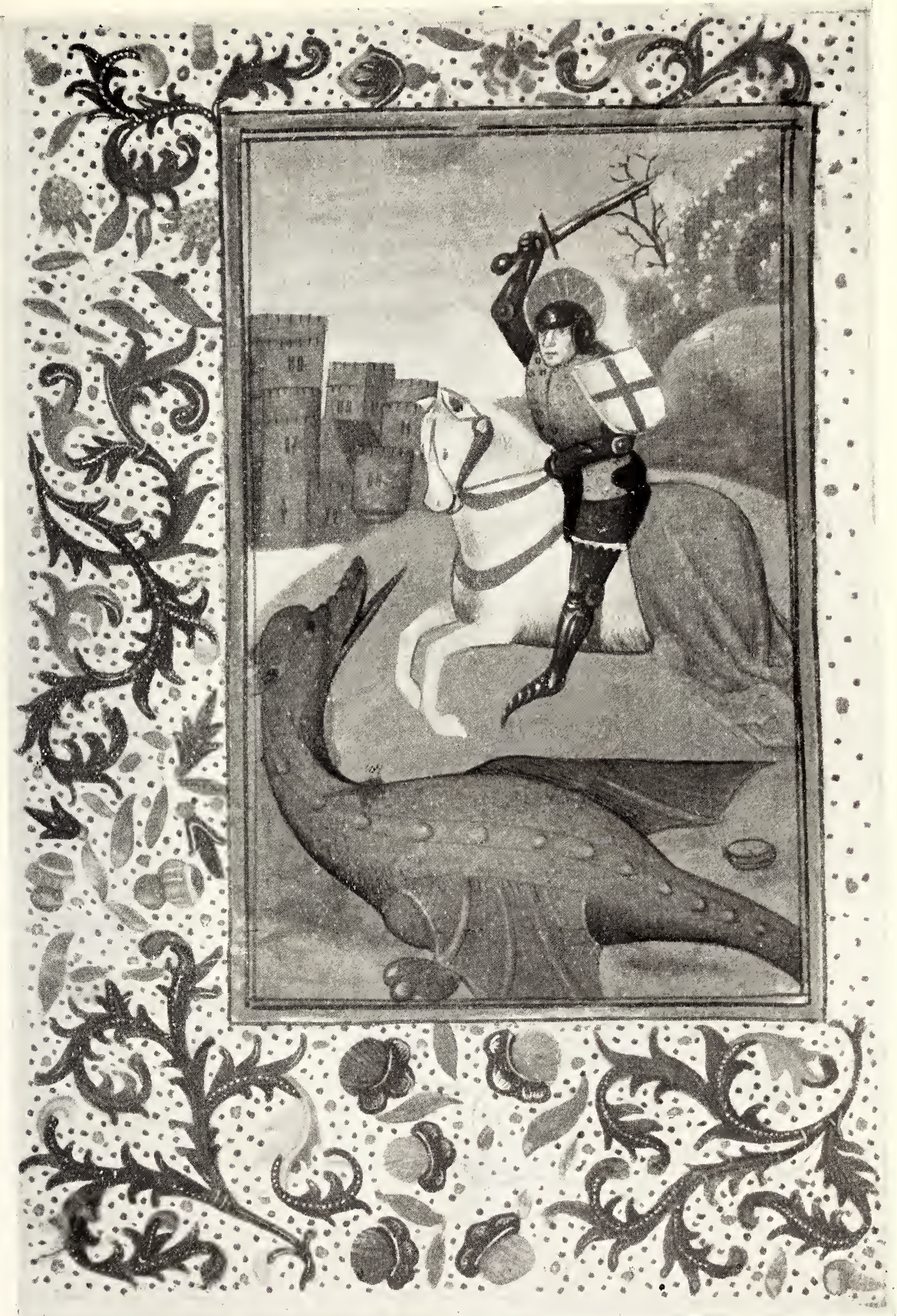

"St. George slaying the Dragon in front of the Tower of London:" A Miniature from Horae Beatae Mariae Virginis. Illuminated Book of Hours for English use on vellum. With 24 full-page Miniatures.' England, XVth Century. See Item No. 52. 


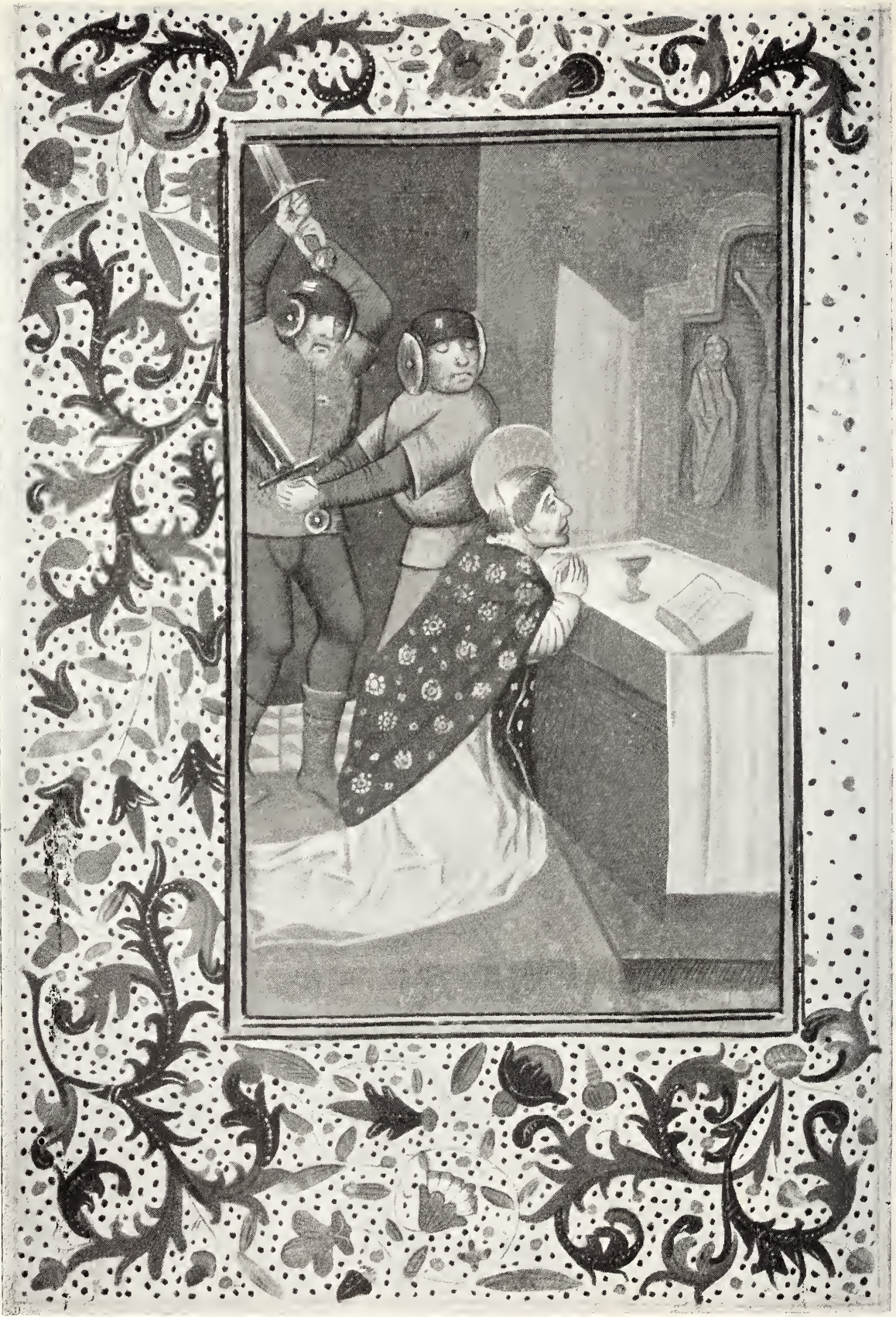

" The Murder of T'homas à Bocket, Arclibishop of Canterbury." A Miniature from Horae Beatae Mariae Virginis. Illuminated Book of Hours for Engtish use on veilum. With 24 trill-page Miniatures. England, XVth Century. 
MAGGS BROS., 34 \& 35, Conduit Street, London, W.

Illuminated BOOK OF Hours FOR English Use.

Horæ Beatæ Mariæ Virginis, cum Kalendario.

"INCIPIUNT HORAE BEATAE MARIAE VIRGINIS SECUNDUM CONSUETUDINEM ANGLIE ECCLESIE."

ILLUMINATED MANUSCRIPT WRITTEN BY AN ENGLISH. SCRIBE (XVth CEN'TURY) ON I 4.4 LEAVES OF VELLUM (8 by $5^{\frac{1}{2}}$ INCHES) IN GO'THIC LETTER, 20 LONG LINES TO A PAGE. WITH 24 FINELY PAINTED FULL-PAGE MINIATURES, EACH WITHIN THREE-QUARTER FLOREATE BORDERS FINEIY PAIN'IED IN GOLD AND COLOURS, 24 INITIAL LETTERS PANINTED IN RED, BLUE AND WHITE ON A GOLD GROUND AND EACH PAGE ON WHICH THEY OCCUR DECORATED WITH A THREE-QUARTER BORDER OF FLOWERS, FRUIT AND ARABESQUES ON A BACK GROUND OF SMALL DOTS. 20 SMALLER MINIATURES REPRESENT ST. MICHAEL, ST. ANDREW, ST. LAURENCE, ST. STEPHEN, ST. NICHOLAS, ADAM AND EVE, THE CRUCIFIXION, THE WOUNDS OF JESUS, ETC., AND I 5 OTHER PAGES WITH BORDERS AT TOP AND BOTTOM, A LARGË NUMBER OF SMALL INITIALS IN GOLD, BLUE AND RED.

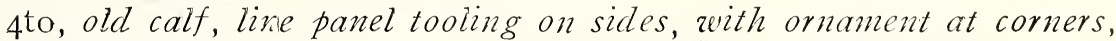
gilt panelled back, g. e.

(England. XVth Century.)

(See Illustrations, Plates Nos. XXVII. and XXVIII.).

$£ 450$

The full-page miniatures represent :-

(1) Jesus adored by two kneeling figures.

(2) The 'Trinity.

(3) St. John the Baptist.

(4) The Murder of Thomas à Becket by two Knights.

(5) St. George slaying the dragon in front of "The Tower of London."

(6) St. Christopher carrying the-infant Jesus across a stream.

(7) St. Anne with the Virgin and child.

(8) St. Catherine and her wheel

(9) St. Mary Magdalene.

(10) St. Margaret escaping from the dragon.

(11) St. Barbara.

(12) Jesus in Gethsemane.

(13) The cutting off of Malchus' ear.

(14) Jesus before Pilate.

(15) The scourging of Jesus.

(16) Jesus carrying the Cross.

(17) The Crucifixion (with St. Mary and St. Johnu).

(18) The Descent from the Cross.

(19) The Entombment.

(20) The Last Judgment.

(21) The Resurrection of the dead

(22) Angels raising souls to Heaven.

(23) Jesus in his tomb with the instruments of the Passion.

(24) St. Jerome. 


\section{HORAE.}

A Dainty BOOK OF Hours.

Horae B. V. M. ad usum romanum, cum Kalendario, etc. (FrancoFlemish XVth Century.)

A CHARMING ILLUMINATED MANUSCRIPT ON VELLUM, 235 LEAVES ( $3 \frac{1}{4}$ by $\left.2 \frac{1}{4}\right)$, WRITTEN IN NEAT SEMI-ROMAN LETTERS, LONG LINES, I6 TO A FULL PAGE, CALENDAR IN RED AND BROWN, RED RUBRICS, NUMEROUS SMALL ILLUMINATED INITIALS, AND PEN-LETTERS IN RED AND BLUE, SOME WITH MARGINAL DECORATIONS.

I4 FINE SMALL ARCHED MINIATURES ( $\mathrm{I}_{\frac{3}{4}}^{3}$ by $\mathrm{I}_{4}^{\frac{1}{4}}$ INCHES), BEAUTIFULLY PAINTED AND ILLUMINATED WITH BORDERS OF RICH FLOREATE SCROLLS, NATURAL FLOWERS, FRUITS, ETC. THE OPPOSITE PAGE TO EACH MINIATURE HAS BORDERS OF A SIMILAR CHARACTER.

I6mo, boarded velvet (blue), with clasps of silver gilt repoussée work.

(France. XVth Century.)

(SeE Illustration, Plate No. XXIX.).

The miniatures are as follows:-

(1) The Crucifixion.

(2) The Descent of the Holy Ghost.

(3) The Infancy of the Virgin.

(4) The Annunciation.

(5) The Visitation.

(6) The Birth of Jesus.

(7) The Angel appearing to the Shepherds

(8) The Adoration of the Magi.

(9) The Circumcision.

(10) The Slaughter of the Innocents.

(11) The Descent into Egypt.

(12) The Coronation of the Virgin.

(13) David composing Psalms.

(14) The Office of the Dead. 


\section{Plate XXIX.}

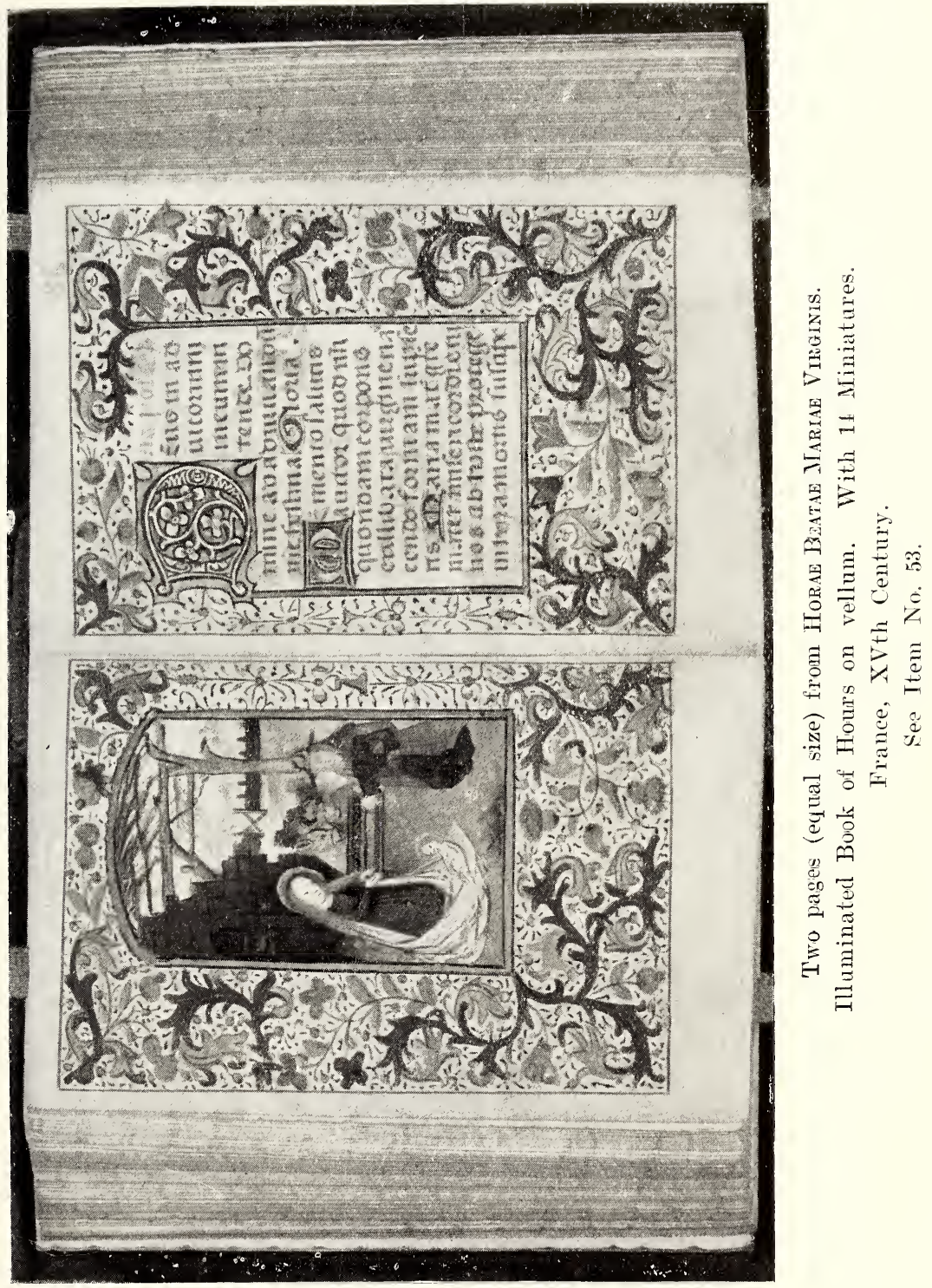




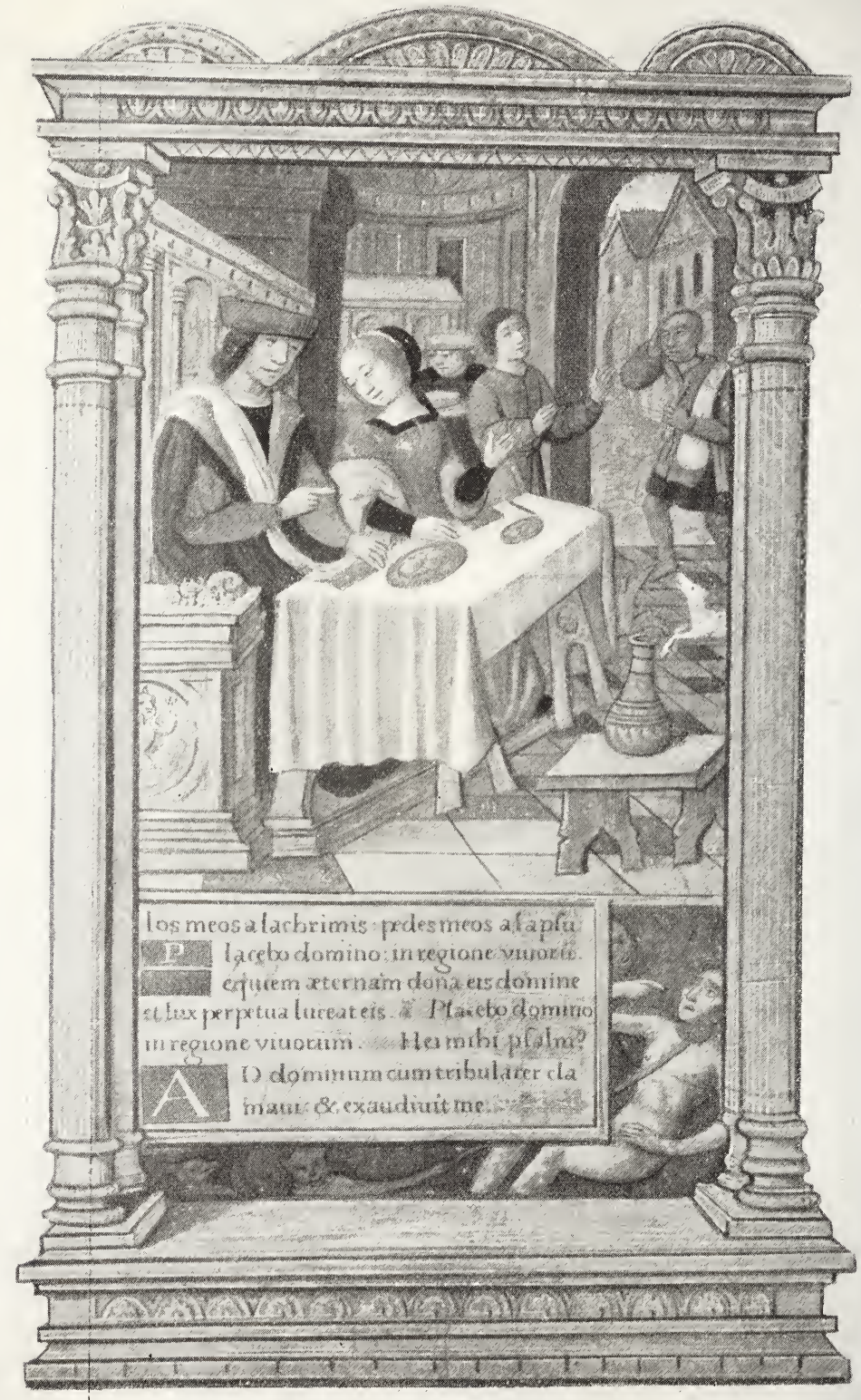

A Miniature from Horae Beatae Mariae Virginis.

Illuminated Book of Hours on vellum. With 15 excellent Miniatures in gold and colours. Italy. XVth Century. See Item No. 54. 
MAGGS BROS., 34 \& 35, Conduit Street, London, W.

\section{HORAE,}

With Fifteen Magnificent Miniatures.

Horæ Beatæ Mariæ Virginis, cum Kalendario,

MANUSCRIPT MAGNIFICENTLY WRITTEN IN MINUSCLES OF THE ITALIAN RENAISSANCE TYPE, KNOWN AS "SCRITTURA UMANISTICA," BY AN ITALIAN SCRIBE ON 79 PAGES OF FINE VELLUM. THE MARGINS ARE CUT AWAY AND THE PAGES INLAID ON PAPER ( $7 \frac{1}{2}$ by $5 \frac{2}{3}$ INCHES).

WITH I5 LARGE AND MAGNIFICENT MINIATURES BEAU'IIFULLY ILLUMINATED BY AN ITALIAN ARTIST OF EXCEP'TIONAL ABILITY WITHIN FLORENTINE FRAMEWORK BORDERS OF GOLD SHADED WITH RED, AND I 5 BEAUTIFUL FULL-PAGE BORDERS OF ARABESQUE DESIGNS SUGGESTIVE OF WROUGHT METAL WORK, IN SHADED GOLD ON RICHLY COLOURED BACKGROUNDS.

ALSO 3 SMALL MINIATURES AND OVER A THOUSAND SMALL INITIAL LETTERS IN GOLD AND COLOURS.

8vo, purple velvet, g. e., with four finely chased gilt clasps.

(Italy. XVth Century.)

(See Illustration, Plate No. XXX.).

$£ 275$

Each page of text of this magnificent manuscript is surrounded with a gold border of knotted cord with tasse's at foot.

The subjects of the large miniatures are:-

(1) Gethsemane.

(2) The Annunciation.

(3) The Visitation.

(4) The Nativity.

(5) The Angel appearing to the Shepherds.

(6) The Adoration of the Magi.

(7) The Presentation in the 'Temple.

(8) Flight into Egypt.

(9) The Coronation of the Virgin.

(10) The Angel Gabriel greeting the Virgin.

(11) The Crucifixion.

(12) The outpouring of the Holy Ghost at Pentecost.

(13) David and Bathsheba.

(14) Dives and Lazarus.

(15) Job and his comforters. 


\section{HORAE.}

\section{Horae Beatae Mariae Virginis.}

ILLUMINATED MANUSCRIPT ON VELLUM (FRENCH XVth CENTURY) ON IIO LEAVES, NEA'ILY WRITTEN IN GOTHIC CHARACTERS, 23 LONG LINES TO A FULL PAGE, WITH I2 ELABORATELY ILLUMINATED PAGES OF CALENDAR, WI'TH 2 REMARTKABLE MINIATURES ON EACH PAGE, AND ONE FULL-PAGE MINIATURE OF THE ASCENSION OF THE VIRGIN AT THE BEGINNING OF THE MANUSCRIPT.

EVERY PAGE IS EMBELLISHED WITH A LARGE AND ELABORATE BORDER ILLUMINATED IN GOLD AND COLOURS, AND AT END ARE SOME SMALL MINIATURES OF SAINTS.

THE CALENDAR IS WRITTEN IN GOLD, BLUE AND RED. SEVERAL HUNDRED INITIAL LETTERS IN GOLD AND COLOURS.

$8 \mathrm{vo}$, red velvet.

(France. XVth Century.)

(See Illustration, Plate No. Xxyi.).

$£ 250$

\section{5a BONATUS.}

Concerning showers and the Mutations of the Air, and what things are conissant about them.

\section{ALBOHAZAN HALY.}

Concerning the Judgment of the Starres.

\section{BONATUS.}

Concerning the Revolutions of Yeares.

\section{PTOlOMEUS.}

Centiloquium or Aphorasmes. Turned into English by Thomas Blackburne.

ENGLISH MANUSCRIPT NEATLY WRITTEN ON 256 LEAVES OF PAPER IN THE XVIth CENTURY.

Folio, original calf, rebacked.

(England. XVIth Century). 
Plate XXYI.

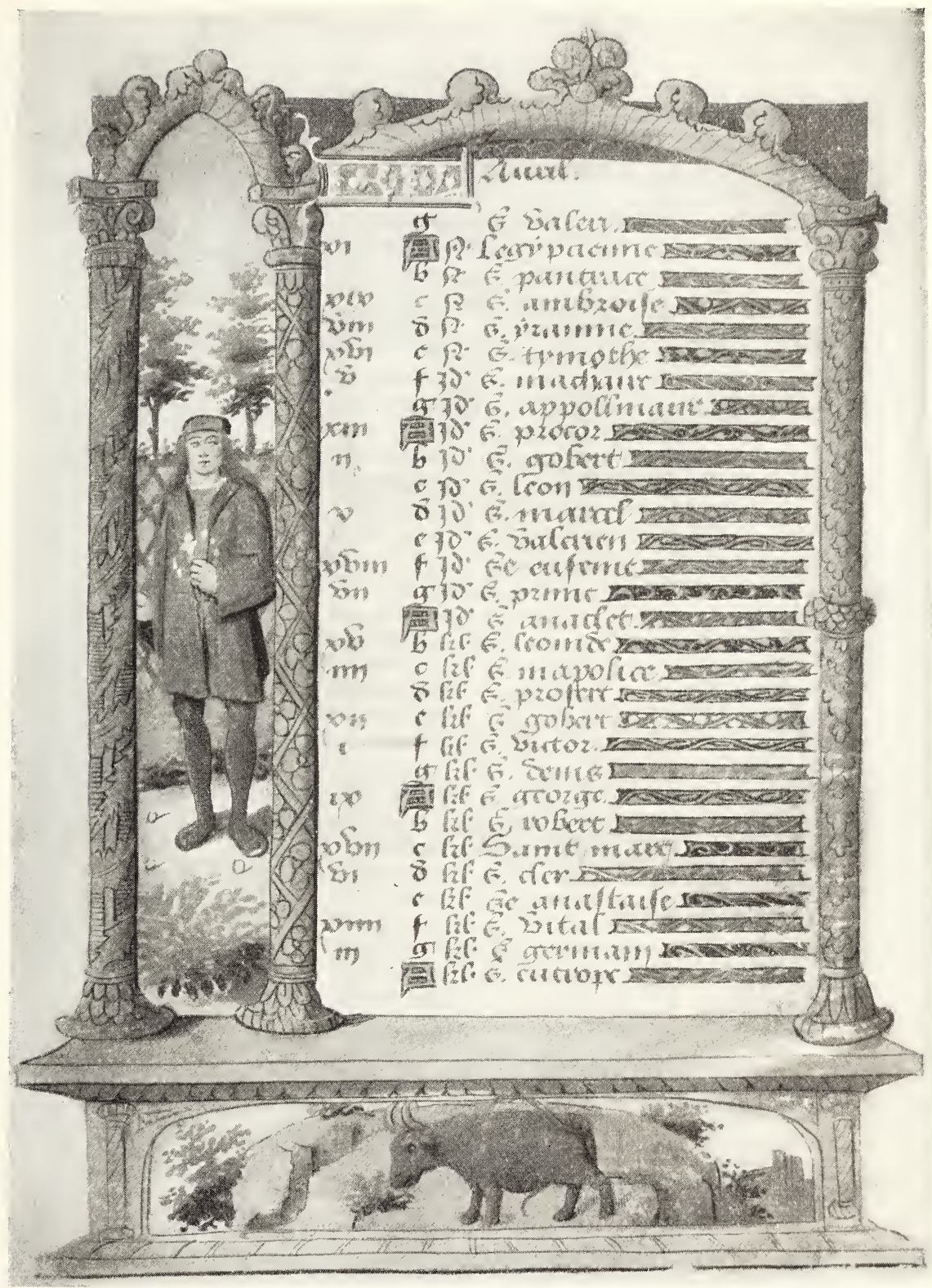

A page of the Calendar from Horae Beatae Mariae Virginis.

Illuminated Book of Hours on vellum. With 2.) Miniatures.

France XVth Century.

See Item No. 5.). 
FOR THE USE OF QUIMPER-CORENTIN IN BRITTANy.

56 HORAE.

Horae Beatae Mariae Virginis cum Kalendario (ad usum QuimperCorentin).

ILLUMINATED MANUSCRIPT ON I 5 I LEAVES OF VELLUM (61. by $4 \frac{3}{4}$ INCHES), WRITTEN BY A FRENCH SCRIBE (XVth CENTURY), I6 LONG LINES TO A PAGE, THE CALENDAR (IN RED, BLUE AND GOLD) AND THE JOYES OF OUR LADY IN FRENCH.

WITH I4 FINE MINIATURES, I4 FULL-PAGE BORDERS, I2 WITH IVY-LEAF PATTERNS IN BURNISHED GOLD AND SMALL BLUE FLOWERS, AND 2 WITH SCROLL WORK. WITH SEVERAL HUNDRED SMALL INITIALS, ABOUT I 50 OF WHICH HAVE SLIGHT BORDERS ATTACHED.

Svo, black morocco.

(France. NVth Century.)

(See Illustration, Plate No. Xxyit.).

$£ 220$

56a (PASSIO JESU CHRISTI, etc.) (Dutch XV century). " Hier begint $d z$ weer de avotmael os here."

DUTCH MANUSCRIPT ON 210 LEAVES OF PAPER ( $5 \frac{1}{2}$ by $3 \frac{1}{2}$ INCHES), WRI'TTEN IN GOTHIC LETTERS, LONG LINES, I 8 TO A FULL PAGE, RED RUBRICS.

Small 8vo, contemporary Netherlands binding of oak boards and leather, zeith stamps of "The Image of Pity," roses and Fleurs de Lys, and legend (worn), with leather and metal clasps.

(Holland. XVth Century.) 


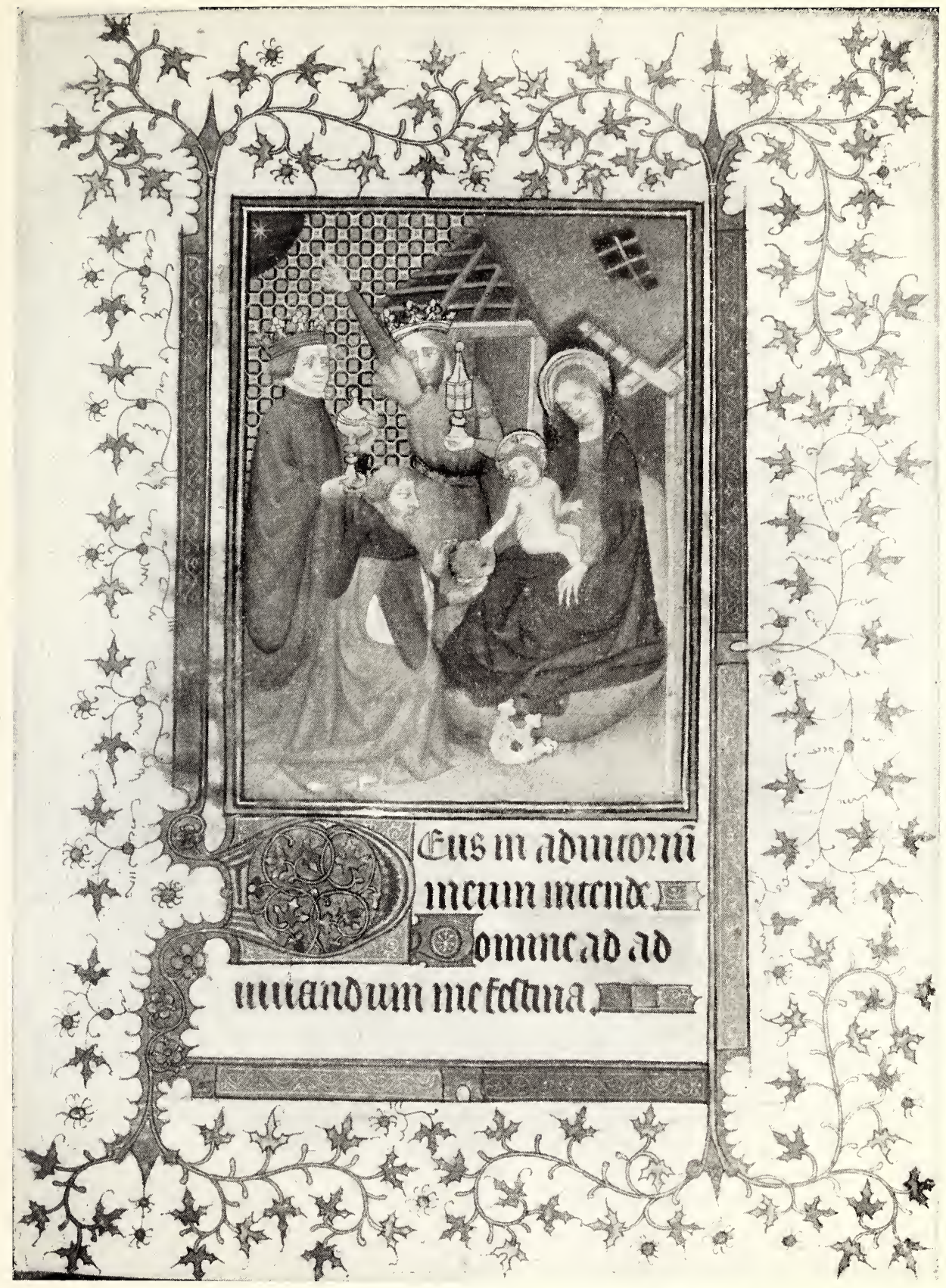

A Miniature from Horae Beatae Mariaf Virgisis ad escul Quimper-Corextix. Illuminated Book of Hours on vellum.

With 14 large Miniatures by a French artist, and 14 full-page borders. France. XVth Century. 


\section{PLATE XXXIII.}

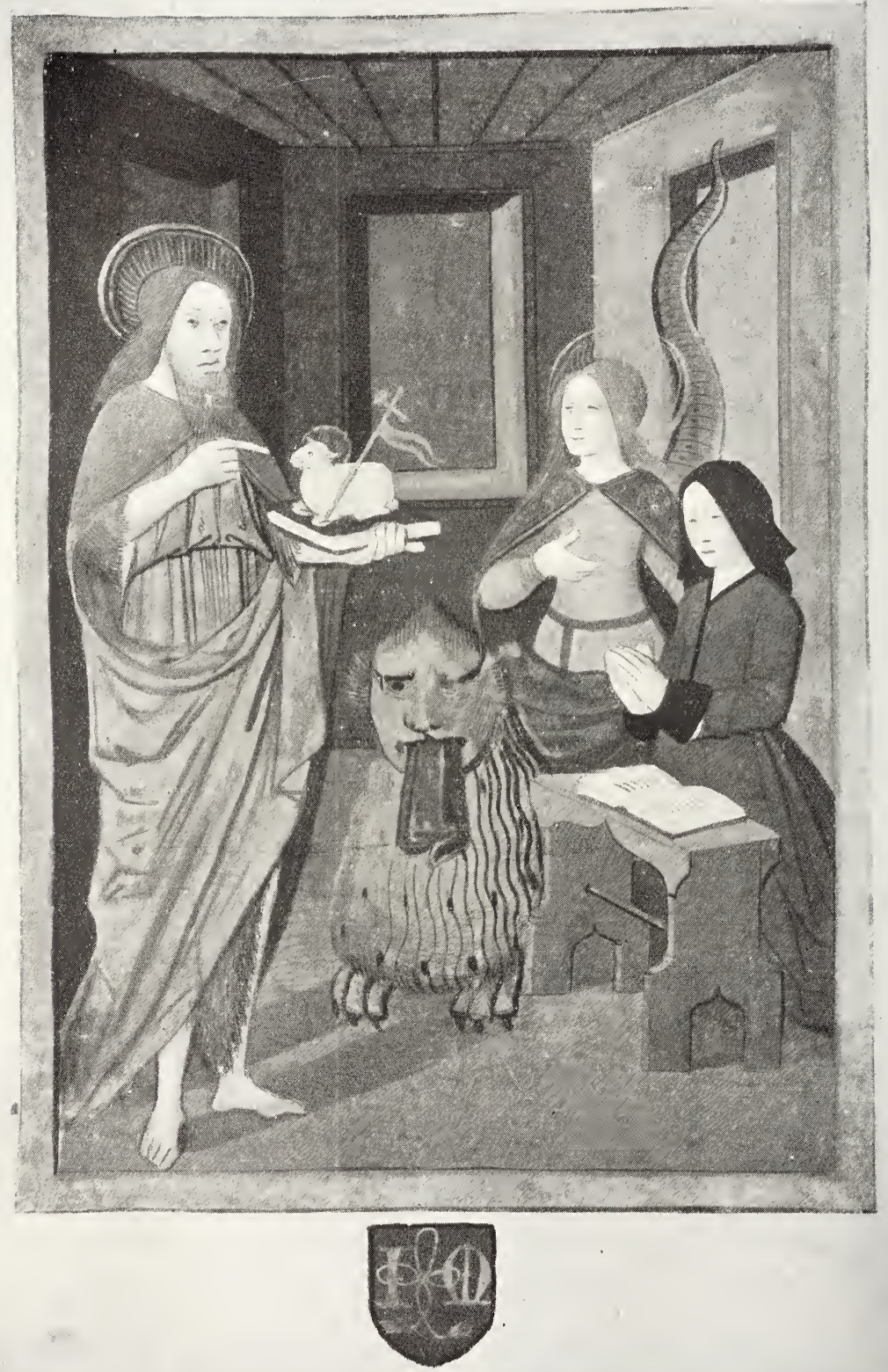

A Miniature from Horae Beatae Mariae Virginis.

Illuminated Book of Hours on vellum. With 72 Miniatures.

France. XVth Century.

See Item No. 57. 


\section{HORAE.}

Horæ Beatæ Mariæ Virginis, secundum usum Romanum, cum Kalendario.

A FINELY EXECUTED MANUSCRIPT ON I39 LEAVES OF VELLUM, BY A FRENCH SCRIBE.

EMBELLISHED WITH AN UNUSUALLY LARGE NUMBER OF CHARMING MINIATURE PAINTINGS IN GOLD AND COLOURS, COMPRISING I2 OF LARGE SIZE, FULL PAGE: 36 SMALLER SQUARE MINIATURES IN THE TEXT, AND 24 IN THE CALENDAR: IN ALL 72, BESIDES HUNDREDS OF SMALL PAINTED INITIALS AND TERMINAL ORNAMENTS, ALSO MANY FLORAL BORDERS; AT COMMENCEMENT IS A LARGE MINIATURE REPRESENTING THE ORIGINAL OWNER OF THE BOOK IN WIDOW'S WEEDS, KNEELING BEFORE A FULL-LENGTH FIGURE OF THE CHRIST, WITH THE INITIALS “I. M.” ON A SHIELD AT FOOT.

Svo, bound in old French dark green morocco, gold lines on sides, full gill back, and giilt edges.

(France. XVth Century.)

(See Illustration, Plate No. XXXiil.).

$£ 220$

*** A fine example of a 15th Century Book of Hours. The large miniatures are:-

I. St. John writing his Gospel.

II. The Annunciation.

III. The Crucifixion.

IV. Descent of the Holy Ghost.

V. The Nativity.

VI. Adoration of the Wise Men. VIT. The Circumcision.

VII!. The Flight into Egypt.

IX. Death of the Virgin.

$\mathrm{X}$. David and Bathsheba.

X1. Job and his three Friends.

XI1. 'The Holy 'Trinity (a curious representation).

The Miniatures in the Calendar represent Country Occupations for each month; and the other paintings are of Scenes in the Lives of Jesus and of the Saints.

\section{7 a VIRGIL.}

With NAMe OF ScRibe.

Bucolics and Georgics (in Latin).

NEATLY WRITTEN MANUSCRIPT ON 8I LEAVES OF PAPER, IO LONG LINES TO A PAGE, HEADINGS AND INITIALS IN RED, RUBRICATED.

8 vo, russia.

(Italy. XVth Century.)

On the last page is a note "Jacobi Philipus scripsit." 


\section{HORAE.}

Horæ Beatæ Mariæ Virginis, cum Kalendario.

ILLUMINATED MS. ON VELLUM (FRENCH XVth CENTURY), I 45 LEAVES ( $5 \frac{5}{8}$ by $3 \frac{3}{4}$ INCHES), WRITTEN IN NEAT ROMAN CHARACTERS, ON RED RULES, 20 LONG LINES TO A PAGE.

ILLUSTRATED WITH I4 FULL-PAGE MINIATURES, FINELY PAINTED IN GOLD AND COLOURS WITHIN ARCHITECTURAL. BORDERS AND FLORAL SCROLLS, NATURAL FLOWERS AND FRUIT ON DULL GOLD GROUND. WITH BIRDS SOMETIMES IN'TRODUCED : I 8 SMALL MINIATURES IN THE TEXT, DEPIC'TING THE TRINITY, MALE AND FEMALE SAINTS, ETC., HÚNDREDS OF INITIALS PAIN'TED IN GOLD AND COLOURS, AND CONSIDERABLF. TEXTUAL ORNAMENT OF BAR PAT'TERN IN SOLID COLOURS WITH GOLD PEN FLOURISHES.

8vo, old crimson morocco gilt, line borders, corner mounts and clasp of chased silver, the clasp bearing the name "H. Revel" engraved on its inner side, edges tooled and gilt (preserved in a leather slip case).

(France. XVth Century.)

(See Illustration, Plate No. XXXiV.).

$£ 175$

A Remarkable italian Binding.

\section{8a PSALTERIUM DAVIDIS.}

(Begins with the Te Deum, followed by some of the Psalms: and ending with some prayers in Italian by the Ven. Bede.)

MANUSCRIP' OF THE XVth CENTURY ON go LEAVES OF PAPER ( 5 by $3 \frac{3}{4}$ INCHES), WITH CAPITALS IN BLUE AND RED.

Small $8 \mathrm{vo}$, in a remarkable specimen of early Itaiian binding. Calf, gilt ornamental back, sides covered with rich gilt panei ornaments, outside border of floreate scrolls, panel of four corner ornaments connected by a mask, in each of which is a sitting dog; centre full-length fugure of a Saint, with a flower vase on either side, and the letters "D.P.C.A.," gilt gauffred edges.

(Italy. XVth Century.)

$£ 25$

\section{$58 \mathrm{~b}$ SENECA.}

Tragoediae.

MANUSCRIPT NEATLY WRITTEN IN ROMANO-GOTHIC CHARACTERS ON I 32 LEAVES OF VELLUM ( I I 1 by $7 \frac{5}{4}$ INCHES) BY AN ITALIAN SCRIBE (XVth CENTURY), 34 LINES TO A PAGE, CAPITALS PAINTED IN RED AND BLUE.

Small folio, old calf.

(Italy. XVth Century.) 
Plate XXXIV.

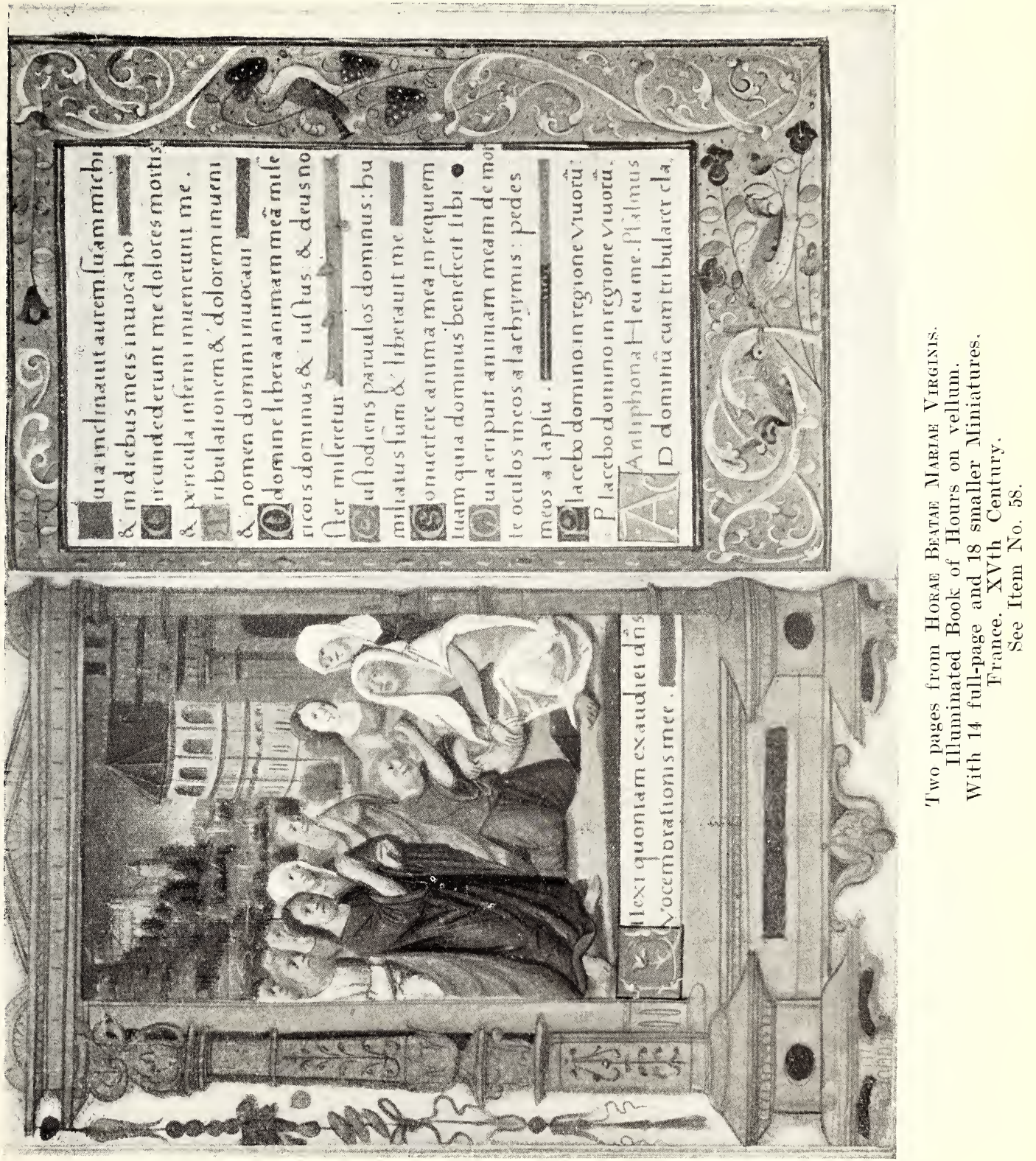




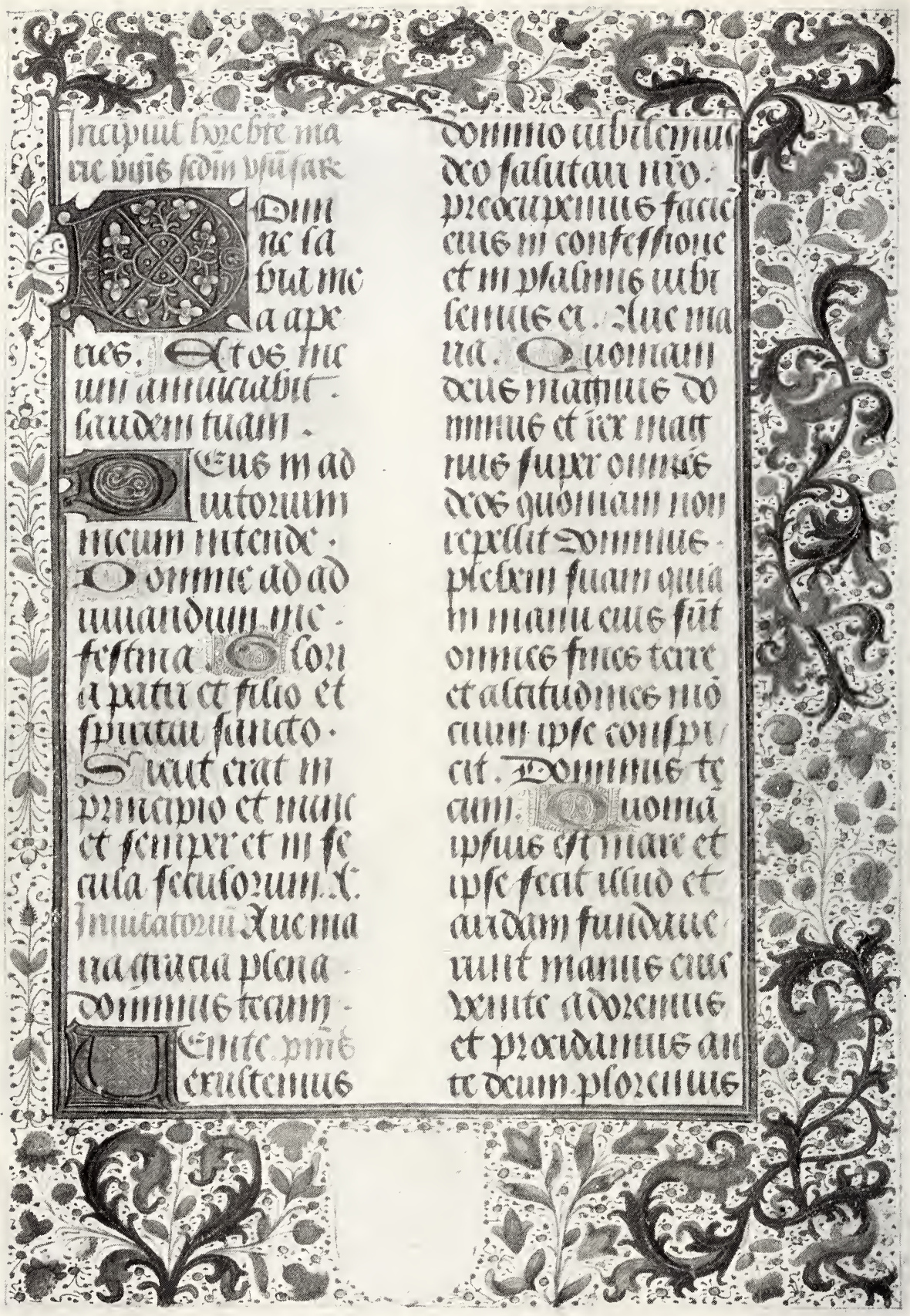

The opening page (greatly reduced) from Horae Beatae Mariae Virginis Secundem Usum Sarum Illuminated Book of Hours for Salisbury use, probably written by Colard Mansion, at Bruges, during the period when William Caxton was working with him. 
MAGGS BROS., 34 \& 35, Conduit Street, London, W.

Book of Hours for Salisbury Use.

\section{HORAE.} dario.

Horæ Beatæ Mariæ Virginis Secundum Usum Sarum, cum Kalen-

A RICHLY ILLUMTNATED MANUSCRIPT ON 74 LEAVES OF VELLUM (I $33^{\frac{3}{2}}$ by $9 \frac{1}{1}$ INCHES), WRITTEN IN BOLD "LETTRES BATARDES," DOUBLE COLUMNS OF 26 LINES, IN RED AND BLACK, EMBELLISHED WITH A PROFUSION OF INITIAL LETTERS IN GOLD AND COLOURS WITH PEN AND INK ORNAMENTATIONS. THE CALENDAR HAS BROAD ILLUMINATED ORNAMENTAL. BORDERS AND II CHARMING MINIATURE PAINTINGS OF THE OCCUPATIONS OF THE MONTHS (THAT FOR MAY CUT OUT).

Folio, bound in modern oak boards with bosses.

(Bruges. Late XVth Century.)

(See Illustration, Plate No. XXXV.).

$£ 115$

A very fine Sarum Book of Hours from Lord Amherst's collection. It is said to have been executed at Bruges in Colard Mansion's printing office, if not by Colard Mansion himself, during the period when William Caxton was working with him. Certainly some of the Caxton type appears to be a modification of the style of writing of this manuseript.

English Medical and Surgical Receipts of the Fifteenth Century.

59a MEDICAL MANUSCRIP'T RECEIPTS IN ENGLISH IN PHYSIC AND SURGERY, AND AN ENGLISH HERBAL MANUSCRIPT (XVth CENTURY), ON 44 LEAVES OF VELLUM ( 8 by 5 INCHES), CON'TAINING MANY IMPORTANT RECIPES, EACH RUBRICA'TED. THE MANUSCRIPT IS WRIT'TEN BY TWO SCRIBES WITH A FEW ADDITIONS BY A LATER HAND.

8vo, original oak boards covered with leather.

(England. XVth Century.)

Contains: "Ypocras yis boke sende to ye Emperor Cesar to Wyte yat yis broke is gode leche."

"For Hed ache and he mow not slepe."

"For hem that mow not slepe."

"For eny evel in ve eye."

"For scalled heddes."

"To make heer to growe."

"For to clere mannes voys."

"For to make clene ye face."

"For to know a man when he be mese! or no."

" For ye jaunes."

"For streyte Brest."

"For ye cold goute or hot." Ete., ete. 


\section{Plate XXXVi.}

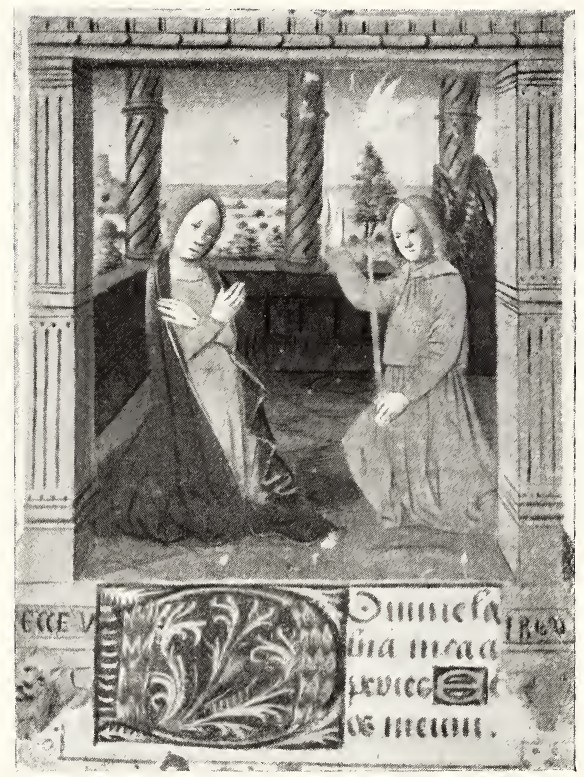

A Miniature (equal size) from Horae Beatae Mariae Virginis.

Illuminated Book of Hours on vellum.

With 13 Miniatures.

Bound in contemporary Lyorese binding.

France. XVth Century.

See Item No. 60. 
MAGGS BROS., 34 \& 35, Conduit Street, London, W.

\section{O HORAE.}

\section{Horæ Beatæ Mariæ Virginis cum Kalendario.}

ILLUMINATED MANUSCRIP'T, WRIT'TEN BY A FRENCH SCRIBE IN THE FIFTEENTH CENTURY, ON I 38 LEAVES OF VELLUM ( $4 \frac{1}{4}$ by 3 INCHES), WRITTEN IN LETTRES BATARDES, I 7 LINES 'IO A PAGE.

WI'TH I 3 ARCHED MINIA'UURES RICHLY PAINTED AND ILLUMINATED IN COLOURS AND GOLD SURROUNDED BY FINE ORNAMEN'TAL ILLUMINATED BORDERS, WITH NUMEROUS SMALL INITIALS ON BLUE AND RED GROUNDS.

Small 8vo, XVth Century brozen calf, beautifully tooled in gold to a fre Lyonese design, gilt back, g. e.

(France. XVth Century.)

(See Illustration, Plate No. NXXVi.).

The miniatures represent:-

(1) The Annunciation

(2) Anne and the Virgin.

(3) The Crucifixion.

(4) The Holy Ghost.

(5) The Birth of Jesus in the Manger.

(6) The Annunciation to the Shepherds.

(7) The Adoration of the Magi.

(8) Presentation in the Temple.

(9) Flight into Egypt.

(10) Coronation of the Virgin.

(11) King David, the Psalmist.

(12) Job and his friends.

(13) Martyrdom of St. Sebastian.

Simon de MONTFORT'S CHRONICLE.

6oa. PETER V., Bishop of Lodève, a Cistercian Monk.

The Chronicle of Simon de Montfort.

LATIN MANUSCRIPT, WRITTEN BY A FRENCH SCRIBE. ON 7 i LEAVES OF VELLUM, DÓUBLE COLUMNS, 4I LINES TO A FULL PAGE, WITH CHAPTER-HEADINGS IN RED, INITIAL-SPACES WITH GUIDE-LET'TERS.

Folio, morocco, inside dentelles, $g . e$.

(France. Early XVth Century.)

$£ 35$

The Firmin-Didot copy, which was sold in 1878 .

This chronicle extends from the year 1200 to 1311 , the period of the condemnation of

the Knights Temiplars, and contains a relation of the wars or Crusades against the Albigenses. It is generally attributed to Peter V. Bishop of Lodève, in 1312, though others attribute it to Bernard Guido. The history has been partly published under the name of William de Puy-Lauant. 
6I HORAE.

\section{Horæ Beatæ Mariæ Virginis cum Kalendario.}

ILLUMINATED MANUSCRIPT ON VELLUM (FRENCH XVth CENTURY), I 55 LEAVES ( $5 \frac{1}{2}$ by $3 \frac{3}{4}$ INCHES), NEATLY WRITTEN IN GOTHIC CHARACTERS, I 5 LONG LINES TO A PAGE, WITH I 3 LARGE MINIATURES WITHIN FULL BORDERS OF FLOREATE SCROLLS WITH FLOWERS AND FRUIT INT'RODUCED, RICHL ${ }^{\prime}$ PAINTED IN GOLD AND COLOURS.

WITH I 3 SMALL MINIATURES OF THE VIRGIN, THE FOUR EVANGELISTS AND VARIOUS SAINTS, WITH THREE-QUARTER BORDERS IN EACH CASE.

THE CALENDAR IS WRITTEN IN GOLD, BLUE AND RED, SEVERAL HUNDREDS OF INITIAL LETTERS PAINTED IN GOLD, BURNISHED, ON PEN-DECORATED GROUNDS OF BLUE AND RED, TEXTUAL ORNAMENTS OF STRAP-WORK AND SMALL OVALS.

Svo, old red morocco gilt, scroll and line borders, $g . e$.

(France. XVth Century.)

(See Illustration, Plate No. XXXViI.).

$£ 85$

The name "Brunet de Montforan 1687" is written in margin of first page.

\section{With Chain Binding.}

\section{I A NICOLAS DE LYRA.}

Postilla.

MANUSCRIPT ON PAPER, DOUBLE COLUMNS.

Folio, XVth Century binding of oak boards covered with pigskin, IO brass bosses on sides, plain back, elongated pieces of leather at top and bottom of back in order to protect the leaves from dust, with stapie and chain composed of three long and one round link, which were used in the oid days to chain this valuable manuscript to its original monastic home.

(XVth Century.)

A REMARKABLE VOLUME FRON A MEDTAEVAL CHAINED LIBRARY, AND A FINE EXAMPLE OF THESE EXTREMELT RARE LITERARY CURIOSITIES.

"IT" IS CERTAINLY DISTRESSING, AS WELL AS A SUGGESTIVE SIGH'T, TO SEE BOOKS IN CHAINS. DISTRESSING BECAUSE A GOOD BOOK IS LIKE A S'TRONG MAN, AND WHEN CHAINED IS AS SHORN SAMSON AMONG 'THE PHILISTINES . . . SO THAT THE MERE SIGH'T OF A SINGLE SURVIVAL OF 'THIS RUDE PRAC'TICE IS S'TRONGLY SUGGESTIVE NOT ONLY OF NATIONAL ADVANCE IN EDUCATION AND LITERARY ENLIGH'TENMENT, BU'J' ALSO OF 'THE POWER OF THE PRIN'TING PRESS, THROUGH WHOSE INFLUENCE ALONE HER OFFSPRING, AS WELL AS. HER PARENTS, THE IIANUSCRIP'T BOOKS, HAVE BEEN REDEEMED FROM THEIR CHAINS."-BLADES.

"THE CUSTOM OF FASTENING BOOKS TO THEIR SHELVES WAS COMMON AT AN EARLY PERIOD THROUGHOU'T ALL EUROPE. WHEN A BOOK WAS GIVEN TO A MEDIAEVAL LIRRARY IT WAS NECESSARY, IN THE FIRS'T PLACE, TO BUY A CHAIN, AND IF THE BOOK WAS OF ESPECIAL VALUE, A PAIR OF CLASPS: SECONDLY, TO EMPLOY A SMITH TO PUT' THEM ON."

A GREAT NUMBER OF THESE MEDIAEVAL LIBRARIES HAVE UNFORTUNATELY BEEN DISPERSED AND OTHERS ADVANCING WITH THE TIMES, HAVE REMIOVED THE CHAINS FROM THEIR BOOKS, SO THAT NOW VERY FEW EXAMPLES ARE EXTANT. 
Plate XXXVII.

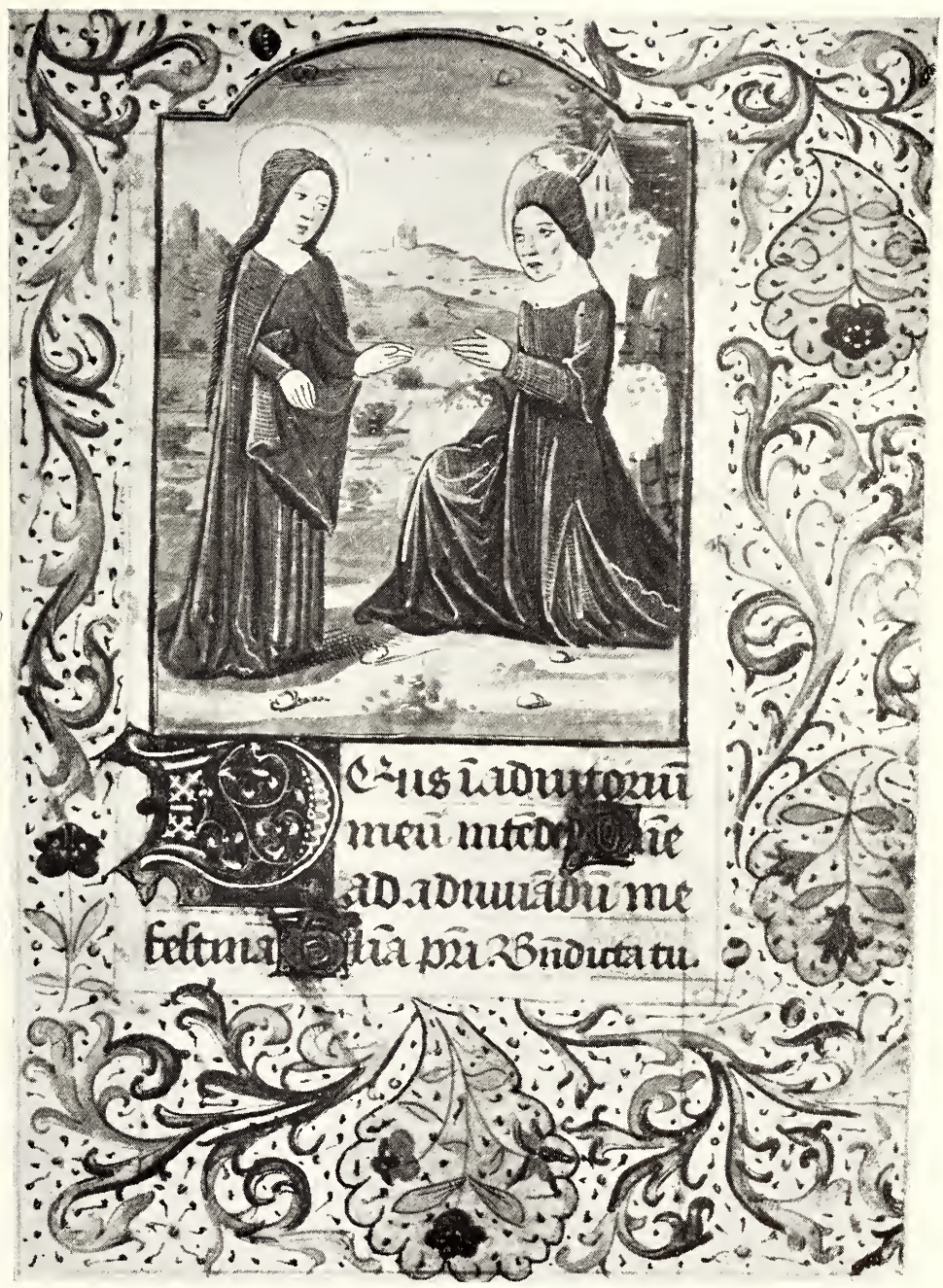

A Miniature from Horae Beatae Mariae Virginis. Illuminated Book of Hours on vellum, with 26 Miniatures. France. $\mathrm{XVth}$ Century. See Item No. 61. 


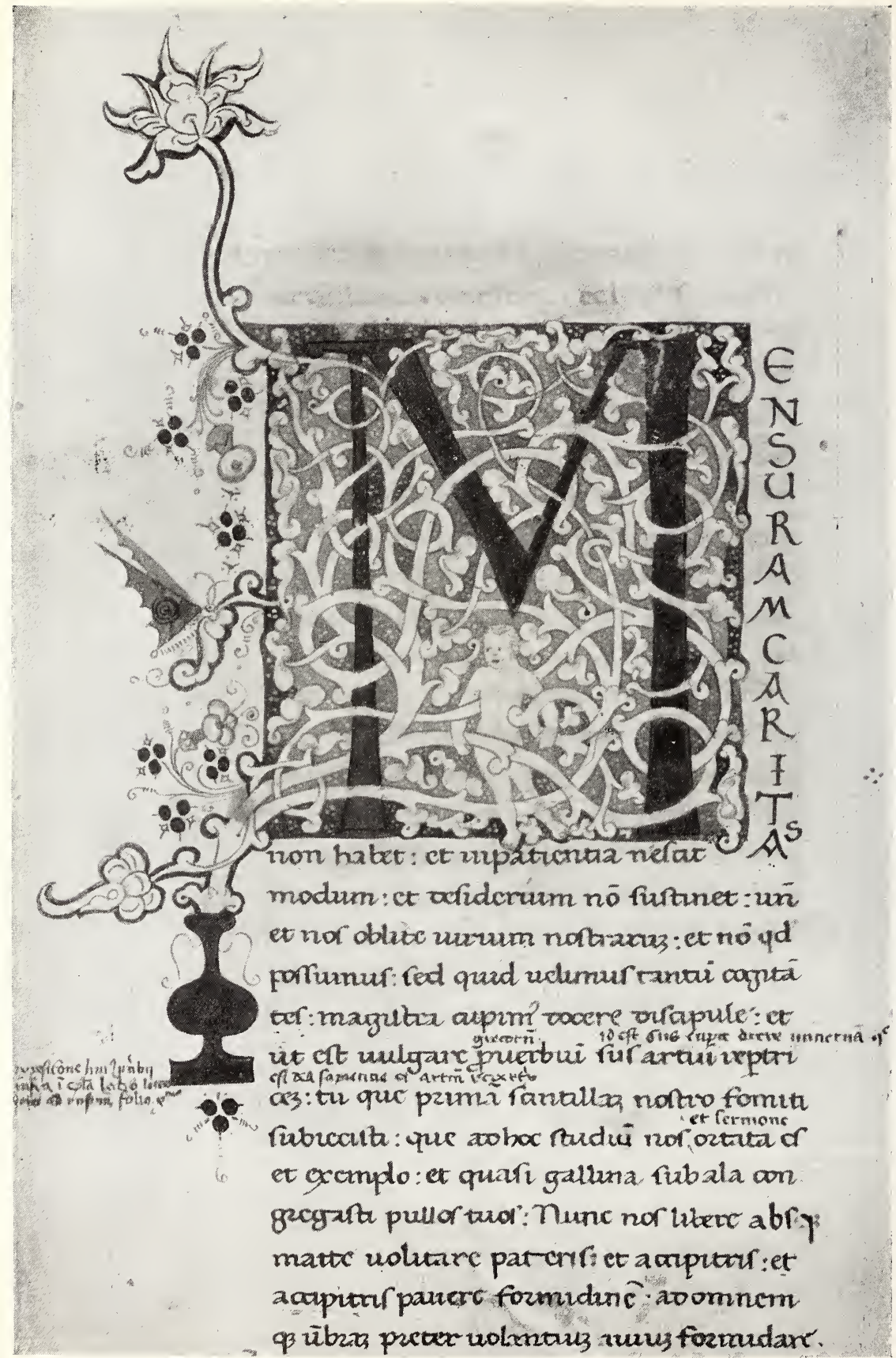

Initial and part of one column from St. Jerome's Epistolat.

Illuminated Latin MS. on vellum by an Italian Scrike. Italy. XIVth Century.

See Item No. 62. 
MAGGS BROS., 34 \& 35, Conduit Street, London, W.

In Magnificent Condition with the Widest Possible. Margins.

JEROME (Saint).

\section{Epistolae.}

MAGNIFICENT ILLUMINATED MANUSCRIPT ON VELLUM, WRIT'TEN BY AN ITALIAN SCRIBE ON 36I LEAVES OF FINE VELLUM ( $13 \frac{3}{4}$ by $9 \frac{1}{2}$ INCHES), IN NEAT ROMAN CHARACTERS, DOUBLE COLUMNS, 4 I LINES TO A PAGE, WITH EXTRAORDINARILY FULL MARGINS WITH 3 LARGE MAGNIFICEN' INITIAL LETTERS PAINTED IN GOLD AND COLOURS, IN THE. ITALIAN STYLE WITH WHITE INTERLACED VINE-STEMS AND CHERUBS AND 259 SMALL INITIALS, WITH MARGINAL NOTES AND RUNNING TITLES IN RED.

Folio, modern velium giit with mosaic of leather ornaments inlaid in red, blue and green, tooled and giit, g. e. (about I850).

(Italy. XIVth Century).

(See Illustration, Plate No. XXXVIII.).

$£ 165$

Fifteenth Century Manuscript by an English Scribe in Contemporary BINDING.

62a LAURENCE (Brother, a Dominican Monk).

Le Livre des Vices et des Vertus.

MANUSCRIPT IN FRENCH ON 95 LEAVES OF VELLUM ( $10 \frac{3}{4}$ by $7 \frac{1}{2}$ INCHES), WRIT'IEN BY AN ENGLISH SCRIBE (XVth CENTURY) IN NEAT LETTRES BATARDES IN 2 COLUMNS OF 40 LINES TO A PAGE.

RUNNING TITLES AND CHAPTER HEADINGS IN RED, INITIALS PAINTED IN RED AND BLUE AL'TERNATELY, WITH PEN DECORATION.

Small folio, original oak boards covered with leather, stamped with fleurs-de-lys (rebacked).

(England, XVth Century.)

$£ 85$

On fly-leaf is the inscription in a fifteen century hand "Whis ys Nicolas Leighe his booke"; also the original cost of the manuscript.

" ye poynte
poynte.
" the byndyng paraffis.
"the velom"

Illegible.

'This work was written by Frère Lorens, the Confessor of l'hilippe 1II. (" the Bold") of France, in 1279. It is an exposition of the Christian Doctrine, containing explanations and commentaries on the Ten Commandments, the Seren leadly Sins, the Twelve Articles of Christian Belief, etc. It enjoyed a wide popularity in the 14th and 15th centuries, being translated into Dutch and English, editions being printed by Caxton, Wynkyn de Worde and Pynson. The first printed edition of this work in the original French was published in 1502 by Vérard. 
63 JEROME (Saint).

(Vita et Obitus ex ejus scriptis congesta; insunt Exhortationes ejusdem necnon Epistolae SS. Eusebii, Augustini et Cyrilli; Prologi S. Hieronymi in libros Bibliorum etc.)

MANUSCRIPT ON FINE VELLUM (XVth CENTURY), 85 LEAVES ( $8 \frac{3}{4}$ by 6 INCHES), WRITTEN IN VERY NEAT ROMAN LETTERS, LONG LINES, 28 'TO A FULL PAGE, RED RUBRICS, BLUE PAIN'TED INITIALS BY AN ITALIAN SCRIBE (the Epistle of Augustine to Cyril appears to be unfinished and four blank leaves follow).

Small 4to, blue morocco with blind and gilt ornaments, g. e., by Thompson (Paris).

(Italy. XVth Century.)

(See Illustration, Plate No. XXYiX.).

A rery beatiful Manuscript of typical Italian beauty and neatness of calligraphy.

\section{LACTANTIUS.}

\section{Fifteenth Century Manuscript.}

\section{Adversus gentiles Institutionum.}

MANUSCRIPT ON VELLUM OF THE XVth CENTURY, WRITTEN IN NEAT ROMAN LETTERS ON I 30 LEAVES ( I I by $7 \frac{1}{2}$ INCHES), BY AN ITALIAN SCRIBE, LONG LINES, 30 TO A FULL PAGE.

WITH THREE INITIALS ILLUMINATED IN GOLD AND COLOURS (THE FIRST IN THE WHITE VINE STYLE).

Folio, green vellum, gilt lines on sides, gilt device of lion rampant in fine panels on back, $g$. e.

(Italy. XVth Century.)

(See Illustration, Plate No. XXXIX.).

A very handsome manuscript in beatiful condition. Spaces are left for the Greek words, but the Latin translation is written over them by the original scribe.

64a MEDICAL RECEIPTS. ENGLISH MANUSCRIPT (XVth CENTURY), WRITTEN IN ENGLISH AND LATIN BY VARIOUS HANDS ON I79 LEAVES OF PAPER ( $5 \frac{3}{4}$ by 4 INCHES).

Small 8vo, original calf, worn.

(England. XVth Century.) 
Plate XXXIX.

DEVITA ET OBITU GLORIOSISSIMI HYCRON.

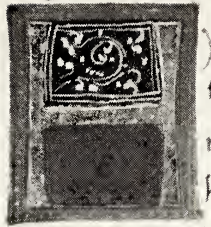
ERONIMVSEYSEBI' U1RI NORILI tiluts aboppido itudonis: quod agbotis euerfum eftrdal matre \& pannomeconfinatenet extatat orundus. bicad

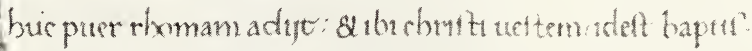

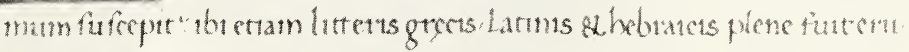
ditus. Subralibus preceptoribus marte grammatce donatum haheut preceptotem. In rechonca autem undorrmum oratorem: fisboqubus la

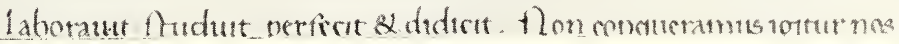

Opening lines from Jerone. Vita. Illuminated MS. on vellun. Italy. XVth Century.

See Item No. 63.

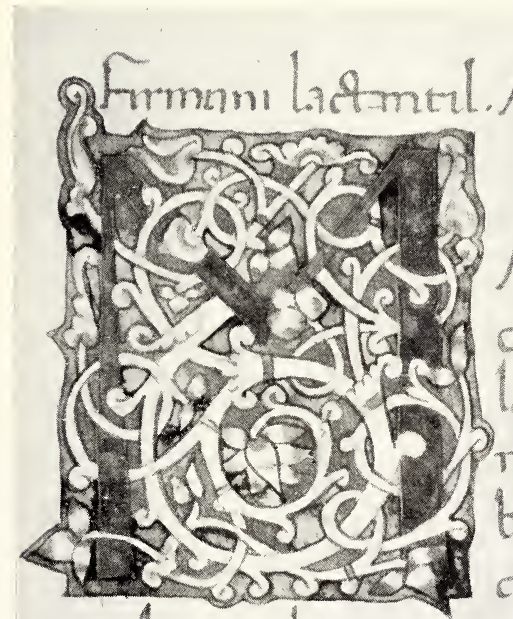

crumr oxilimanter multo effe-

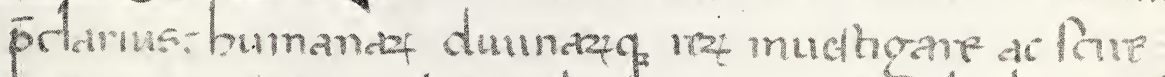
ratimem - q Atruendir opbus aut rimulindis homorib? intorer Qubus rous qm Fragles romen funt et adfoluf corpons ponent cultum - nemo molior nemo

Opening lines from Lactantius. Adversus Gentiles.

Illuminated MS. on vellum. Italy. XVth Century. See Item No. 64. 


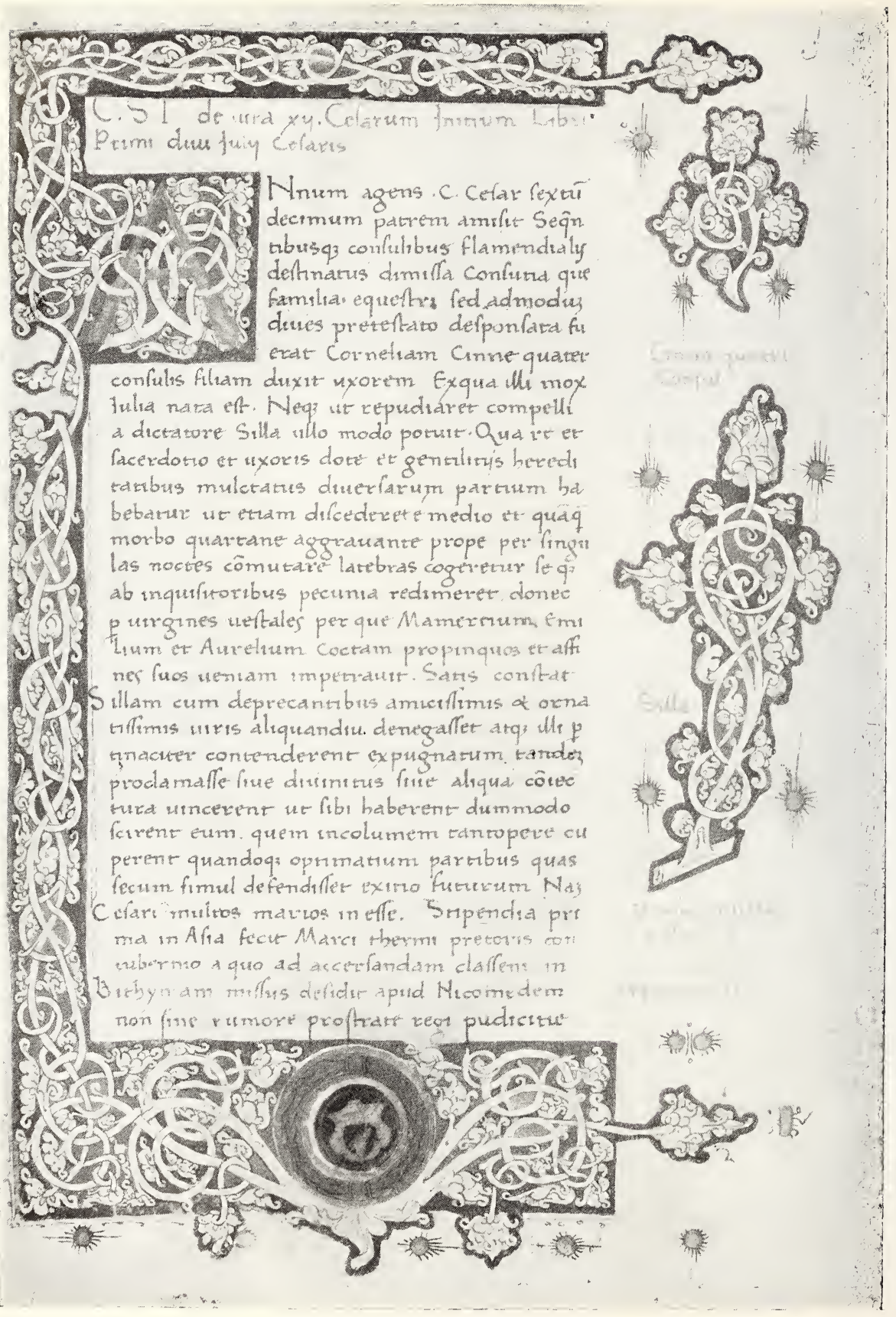

Opening page from Suetonius. The Lives of the Caesars (in Latin). Illuminated MS. on vellum. Italy. XVth Century. See Item No. 72. 
The Famous Lives of the Caesars.

\section{SUETONIUS.}

Lives of the 12 Caesars. (In Latin.)

BEAUTIFULLY WRITTEN MANUSCRIPT BY AN ITALIAN HAND ON I 58 LEAVES OF VELLUM, WRITTEN IN NEAT ROMAN CHARACTERS, 34 LONG LINES TO A PAGE, RUNNING TITLES AND MARGINAL REFERENCES IN RED.

WITH $\sigma$ LARGE ILLUMINATED ORNAMENTAL INITIALS, BEAUTIFULLY ILLUMINATED IN THE ITALIAN MANNER, OF INTERLACED WHITE VINE STEMS ON COLOURED GROUND HEIGHTENED WITH GOLD. TEXT ON FIRST PAGE OF WORK IS SURROUNDED BY BORDERS, WITH THE SFORZA ARMS (rubbed AT FOO'T'.

Folio, old red sheep, back gill, g. e.

(Italy. XVth Century.)

(See Illustration, Plate No. Xl.).

$£ 125$

A VERY HANDSOME WORK; MANUSCRIPTS OF THE LIVES OF THE CAESARS BY SUETONIUS ARE RARELY ME'T WITH. 
Written for Antonio Piccolomini, Nephew of Pope Pius II.

Aeneid (in Latin).

MANUSCRIP'T ON I80 LEAVES OF VELLUM ( $10 \frac{1}{4}$ by 7 INCHES), NEATLY WRITTEN BY AN ITALIAN SCRIBE IN "SCRITTURA UMANISTICA," 28 LONG LINES TO A FULL PAGE, THE FIRST PAGE WITH AN ILLUMINATED MARGIN OF WHITE VINE WORK PAINTED IN GOLD AND COLOURS AND THE ARMS OF ANTONIO PICCOLOMINI DE ARAGONIA. WITH HEADINGS IN RED AND INITIALS IN BLUE.

Small folio, russia gilt.

(Italy. XVth Century.)

(See Illustration, Plate No. Xli.).

$£ 165$

Antonio Piccolomini for whom the manuscript was written was a nephew of Pope Pius II. (Aeneas Sylvius). He married a daughter of King Ferdinand I. of Naples

in 1467. This manuscript was later in the Askew and Woodhull collections.

\section{VIRGIL.}

Aeneid (in Latin).

MANUSCRIP'T WRITTEN ON I66 LEAVES OF PAPER IN A VERY NEA'T HAND, 30 L.ONG LINES TO A PAGE. INITIAL LETTER ON THE FIRST PAGE IN RED AND BLUE. WITH ORNAMENTAL PEN WORK, AND O'THER FINE INITIAL LETTERS THROUGHOUT THE TEX'T IN RED AND BLUE.

Folio, half bound.

(Italy. XVth Century.)

$£ 21$

Several leaves repaired.

\section{VIRGIL.}

With NAME OF SCRIBE.

Georgics and Aeneid (in Latin).

MANUSCRIPT ON I8O LEAVES OF PAPER CAREFULLY WRITTEN, LONG LINES, SOME MANUSCRIP'T NO'TES IN THE MARGIN (the last two leaves repaired).

Folio, calf gilt, plain line borders on sides.

(Italy. XVth Century.)

$£ 15155$

On the last page are the words "Scriptus per me Antonium de (Floribus?)." 


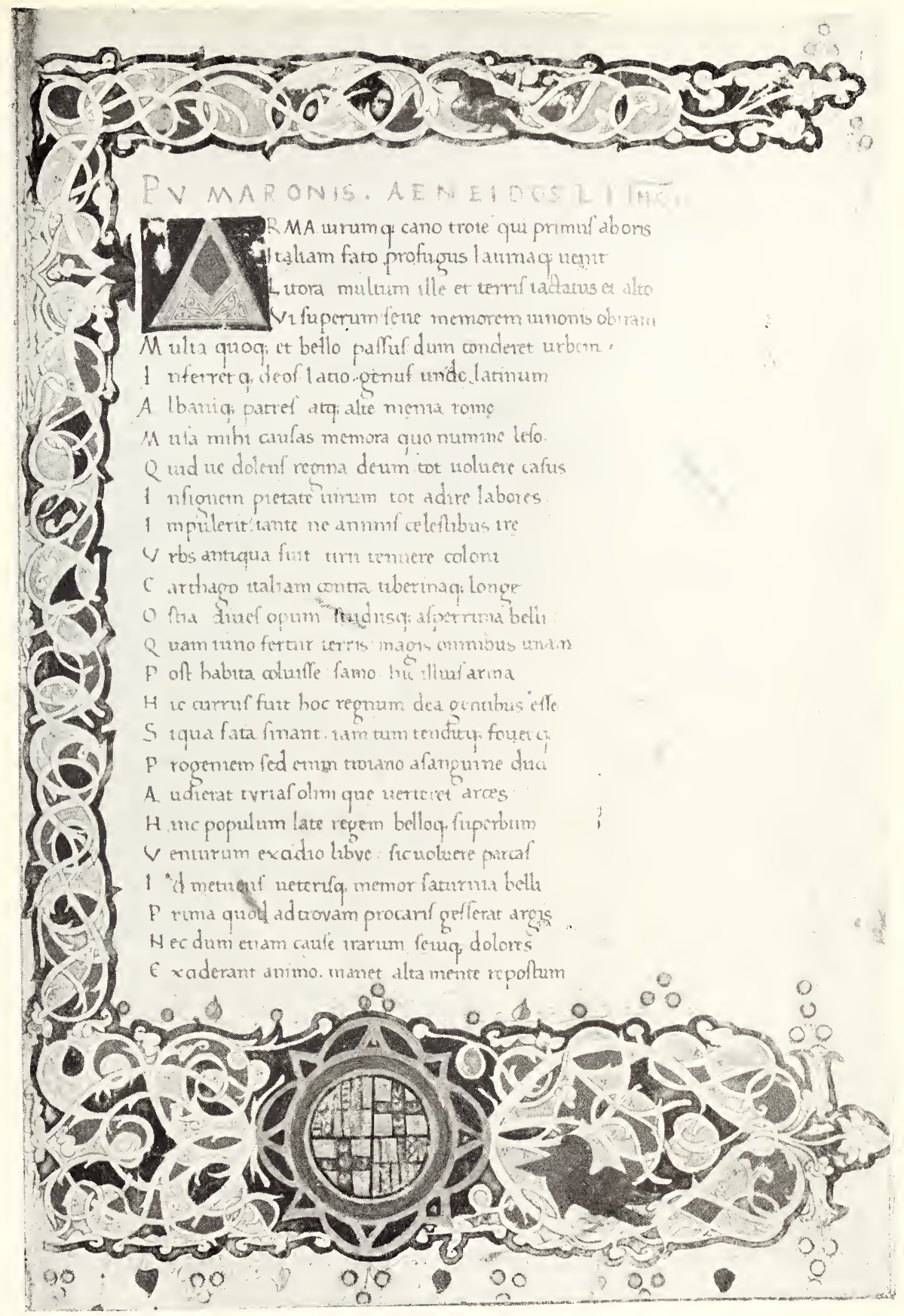

First page from VIrGIL's ArNid. THuminated IIS. on rellum. Italy, XVth Century. See Item No. 73. 


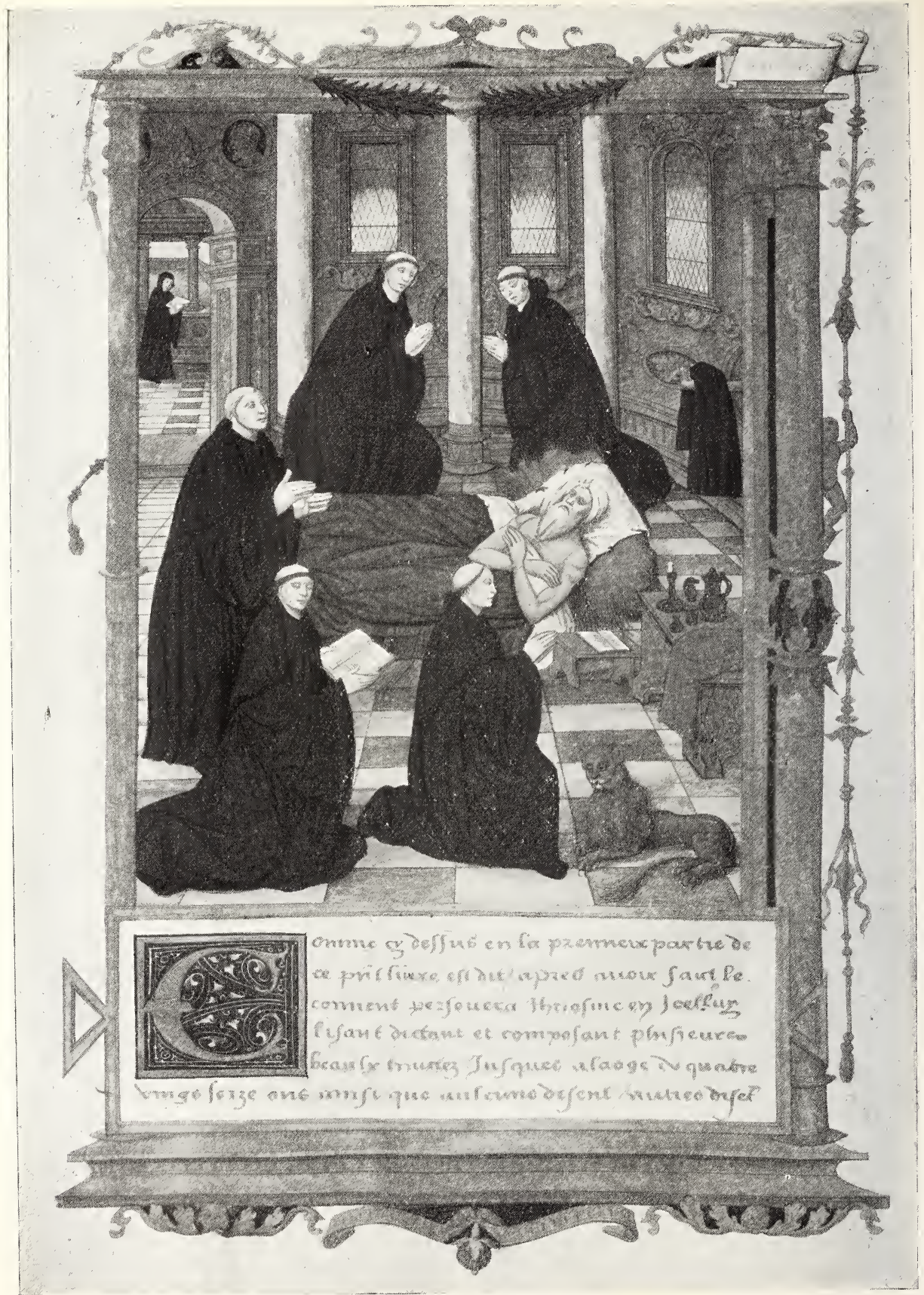

A Miniature from Jerone. Vie, Mort et Miracles.

Illuminated MS. on vellum. With 5 Miniatures.

Paris. Albout A.D. 1520.

See Item No. 78 
MAGGS BROS., 34 \& 35. Conduit Street, London, W.

With Five Magnificent Full-Page Miniatures.

78 JEROME (Saint).

\section{Hierome.," \\ " La Très-Saincte Vie, Mort et Miracles du glorieux Sainct}

ILLUMINATED MANUSCRIPT IN FRENCH, MOST BEAUTIFULLY AND LEGIBLY WRITTEN AT PARIS ON I 49 LEAVES OF VELLUM.

WITH HUNDREDS OF TINY INITIAL LETTERS BEAUTIFULLI' PAINTED IN GOLD AND COLOURS.

WITH FIVE MAGNIFICENT FULL-PAGE MINIATURES ADMIRABLY ILLUMINATED IN GOLD AND COLOURS.

Folio, brown plush, g. e.

(Paris. About I 520.)

(See Illustrations, Frontispiece and Plate No. XliI.). £1,650

This manuscript is similar to MS. français No. 418 now at the Bibliothèque Nationale, Paris, with the same title and subject " "The most holy Life, Death and Miracles of Saint Jerome") which was executẻd for Anne of Parma, Duchess of Bourbon. The miniatures of our manuscript resemble, as regards the remarkable borders, the preliminary miniatures of certain MSS. of the Statutes of Saint Michael, dating from the reign of King Francis I. of France, which have been published and described by Comte Paul Durrieu in volume 1. of the Bulletin de la Société Française de reproduction de manuscrits; one of these manuscripts was sent as a gift in 1527 by King Francis I. of France to Henry VIII. of England.

While it is impossible for us to name the artist who painted the superb miniatures which adorn our manuscript there is no doubt that they are the product of one of the "Illuminators," who worked at Paris during the reign of Francis I.

List of Miniatures.

1. The author, in a black habit, wearing over it a purple gown trimmed with gold and lined with white silk, with a black cap on his head, is seated in a magnificently carved wooden armchair, writing with a quill pen on a !ong sheet of vellum, half folded on a carred wooden writing desk. His study is a magnificent room with seats, book-stands and shelves, and contains gaily-covered books. Through an open window is seen a landscape, with castles, meadows, forests, a church, a river and the blue haze of mountains.

2. Saint Michael, in golden armour under which he wears a blue coat of chain mail, is appearing to "Faith" and "Lady Church" (Dame Eglise), behind each of these is an Attendant with Emblems.

3. The Baptism of Saint Jerome. On the right half of the miniature is his birth chamber; his mother Theodora is reclining in bed, atteuded by three women. On the left is the baptism, while in the background a woman is drying sheets before a fire.

4. Saint Jerome on horseback attended by his lior, with an array of finely-dressed attendants is riding in a forest, superintending the building of a church and monastery illustrating Saint Jerome's Life in the Desert.

5. The death of Saint Jerome in his cell. Lying on a bed of straw and surrounded by six kneeling and praying monks, all dressed in black robos and with shaven crowns. St. Jerome is seen dying, an open book by his side, a lighted candle is nearly burnt out, and his lion bears a resigned and mournful visage.; St. Jerome has a long white beard and a handkerchief tied round his head and is awaiting the end, his arms crossed over his bare chest. The painting of the facial expressions on the faces of St. Jerome and the praying monks is a masterpiece. 
96 MAGGS BROS., 34 \& 35, Conduit Street, London, W.

\section{ARISTOTLE.}

De Interpretatione, with Commentaries.

MANUSCRIPT WRITTEN IN LATIN WITH NUMEROUS DIAGRAMS.

Folio, original oak boards, with clasps.

(About I 526.)

£6 6s

THE LAW OF BOHEMIA.

8o REFORMATIONSORDNUNG, Neue, und Recht des Landes und König. reichs Böhem, auss Böhemischer in die Teutsche Sprach transferirt.

GERMAN MANUSCRIPT ON PAPER DATED I 572. vellum.

Folio, original stamped leather, back repaired with a large piece of

(Austria. I 572. )

$£ 55 s$

A translation into German of the Constitution and Laws of the Kingdom of Bohemia in 1564 .

S I GRADUALE, for the use of the Clarissan Nuns of the Convent of St. Catharine of the diocese of Salzburg, or Passau.

MANUSCRIPT BEAUTIFULLY WRIT'TEN ON 308 LEAVES OF VELLUM TOGETHER WITH TWO FULL INDICES, WITH NUMEROUS HEADINGS IN RED AND ORNAMENTAL' ILLUMINATED BORDERS. WITH NUMEROUS LARGE HISTORIATED INITIAL'S IN GOLD AND COLOURS, WITH MUSICAL NOTATION THROUGHOUT.

2 vols., royal 8vo, original binding of oak boards covered with stamped pigskin and two clasps.

(Austria. About I 590.)

(See Illustration, Plate No. Xliil.).

$£ 108$

The first volume contains the Sanctorale, the second the communes of the Saints and votive Masses.

The history of the composition of liturgical chants can be studied with profit in this manuscript for it contains a large number of Masses of which the text has been adapted according to the tradition of the Church to Gregorian melodies.

For instance the "conception of the Virgin," "the Holy name of Jesus," together with its sequence, the melody of which followed exactly the melody of the Corpus Christi according to the rhythmic scheme of the text. Also "Saint Gabriel" with the sequence "Felix tempus numeravit quo suam plebem visitavit deus ex alto" oriens"; "the Transfiguration"; "the Guardian Angel"; "Saint Diego." 
Plate XliII.

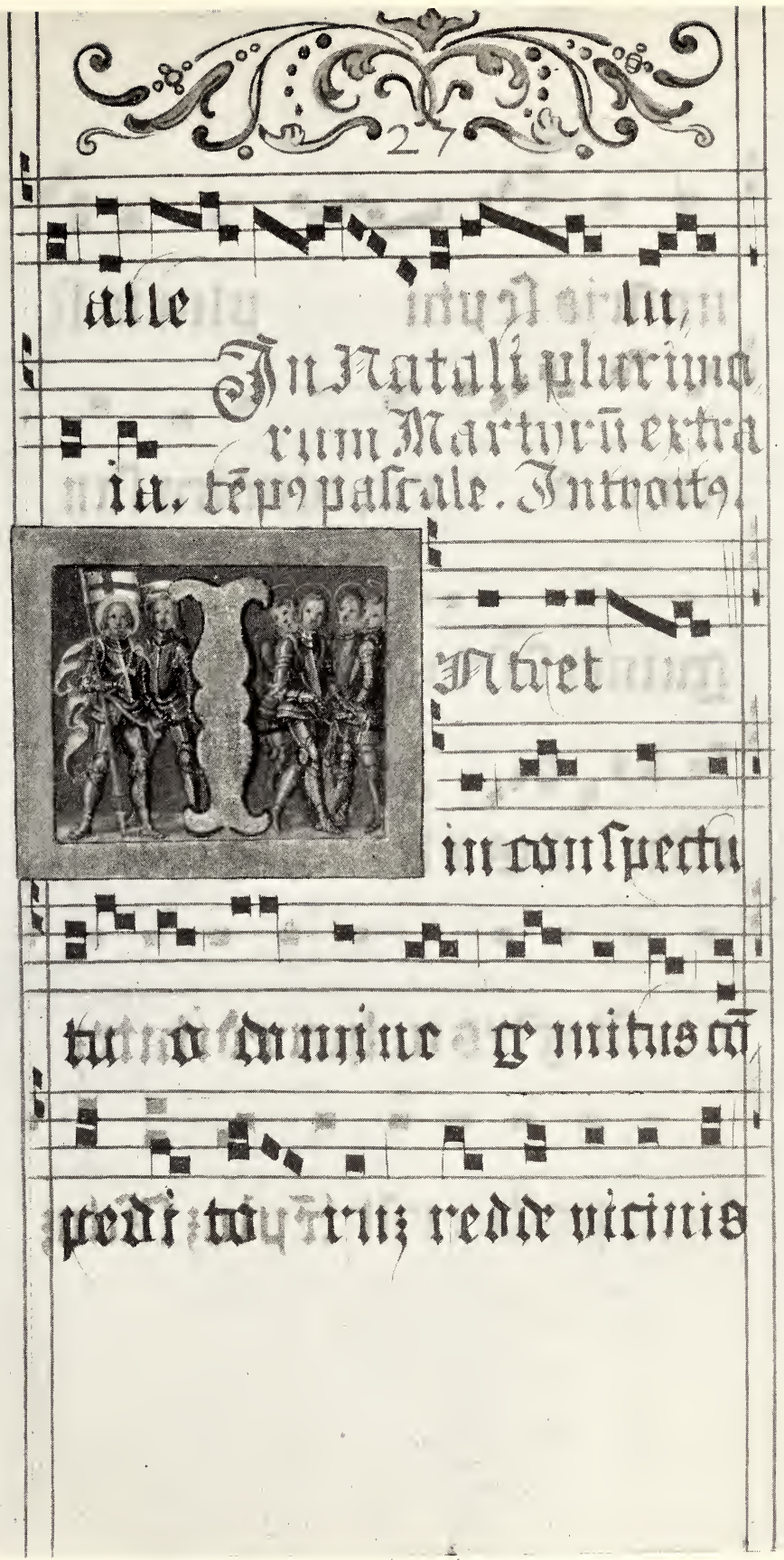

A page from a Graduale for the Úse of Clarissan Nuns. Illuminated MS. on vellum.

With numerous historiated capitals in gold and colours and musical notation throughout. Austria. About 1590.

See Item No. 81. 


\section{Plate XLIV.}

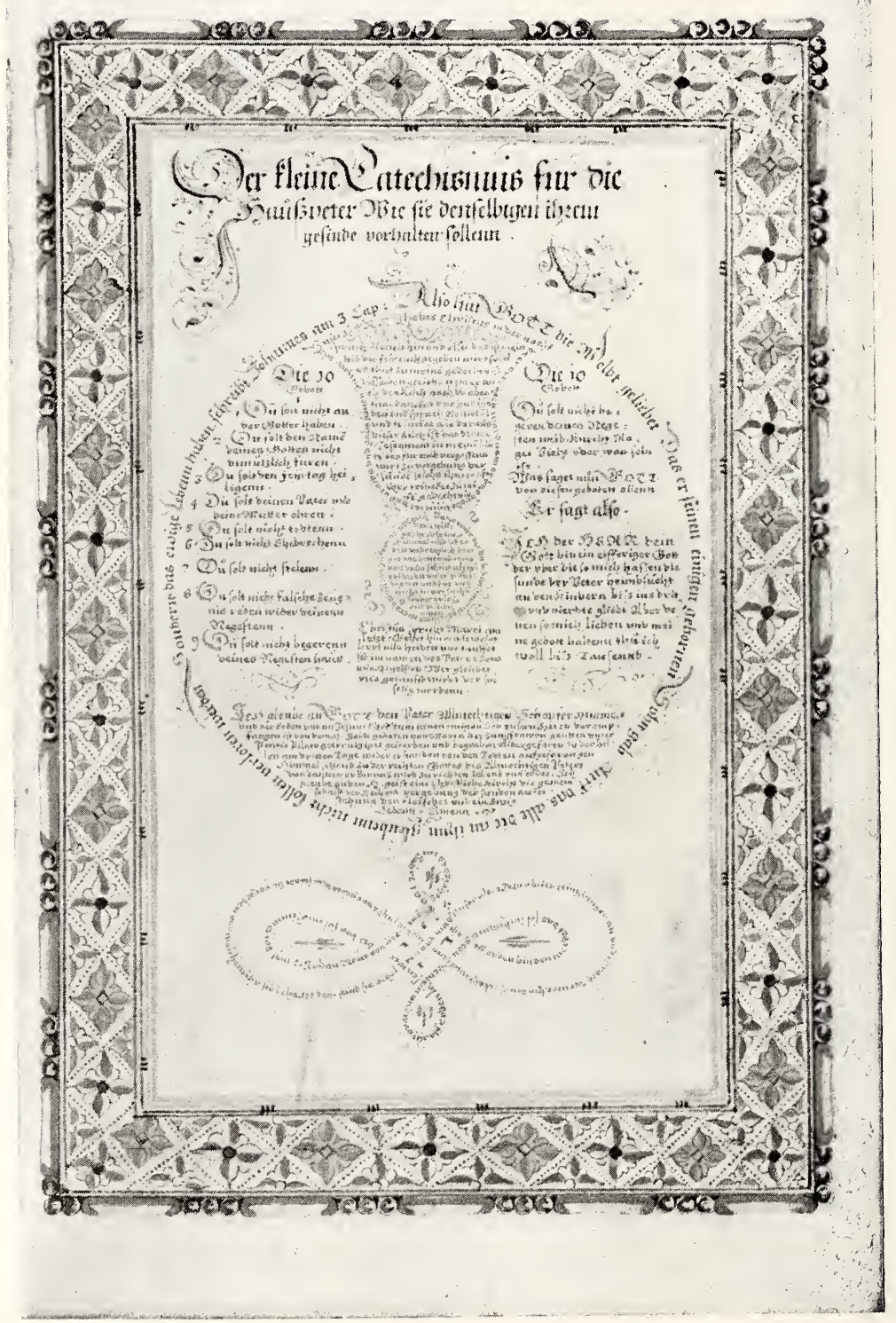

A page from Book of Devotions, remarkable specimen of Calligraphy on vellum. Bremen, 1610.

See Item No. 83. 


\section{NOTARIAL COPIES OF ORIGINAL DOCUMENTS relating to Councils, Ecclesiastical Privileges, etc.}

Ordinances of the Provincial Synod of Barre (16-), Acta Concilii Provincialis Rememsis (Rheims, France), AND OTHER DOCUMENTS, IN ALL 6o LEAVES IN VARIOUS ITALIAN HANDS WITH NOTARIAL SIGNATURES, WRITTEN BY VARIOUS HANDS AT DIFFERENT DATES ON SUBJECTS RELATING TO COUNCILS, ETC.

Small folio, original Venetian binding of oak boards and stamped ornamental brown morocco with metal bosses and four clasps (well preserved), with an old Italian Archbishop's ex libris in cover.

(XVIIth Century.)

$£ 1010 \mathrm{~s}$

Fine specimen of early XVIIth Century Venetian binding.

Remarkable Specimen of Calligraphy.

\section{CALligraphy.}

A BOOK OF DEVOTIONS FINELY WRITTEN ON 46 LEAVES OF FINE VELLUM BY JOHANN NEUEN OF BREMEN IN THE YEAR I6IO FOR HANS HAGMEIER.

EACH PAGE OF THE TEXT IS SURROUNDED BY BORDERS OF SEVERAL DESIGNS, EXECUTED IN DELICATE PEN WORK HEIGHTENED WITH GOLD AND COLOURS, THE INITIAL LETTERS ARE FINELY EXECUTED IN GOLD, WITH ELABORATE PEN ORNAMENTATION. THE HEADINGS ARE IN RED.

$8 \mathrm{vo}$, contemporary red velvet binding.

(Bremen, iбío.)

(See Illustration, Plate No. XliV.).

$£ 25$

The whole calendar for the year, with a Saint for each day, is written in a fine minute hand on one page of text, measuring $4 \frac{1}{4}$ by $2 \frac{3}{4}$ inches. The page containing the Catechism is written in the form of a cup with ornamental scrolls, so minutely written that portions require a magnifying glass to decipher them. 
With 68 Dainty Emblematic Miniatures.

84 MYSTICAL. Le Dodeci Divotioni Spirituali ne quali si comprendono bellissime Orationi di Consolatione, veri remedii e mezi per qualagnare et ottenere in Dio benigno e clemente, una Coscienza quieta e goiosa \& in fine la Corona della Vita eterna. Composte in lingua Tedesca per Filippo Chegel e tradotte in lingua Italiana, scritte e miniate, per Ercombaldo Freschel.

ITALIAN MANUSCRIPT BEAUTIFULLY WRI'TTEN ON I94 LEAVES OF PAPER, WITH 68 DAINTY EMBLEMATIC MINIATURES DELICATELY ILLUMINATED IN GOLD AND COLOURS, WRITTEN AND PAIN'TED BY ERCOMBALDO FRESCHEL DURING THE YEARS I6II-I3, TWELVE ILLUMINATED TITLES AND TAIL-PIECES AND MUSIC NOTES.

Royal 8vo, velvet binding.

(Italy. I6I I-I6I3.)

(See Illustration, Plate No. XlV.).

$£ 5210$ s

The dainty mystical miniatures are beautifully painted in the margins, and in many cases illustrate early 17 th century daily life and daily customs in Italy.

Medical ManUsCRipt.

84a CAstrucci (Leone).

L'Arte della Medicina.

ITALIAN MANUSCRIPT ON ABOUT 80 LEAVES ON PAPER (ITALIAN XVIIth CE.TURY), A LARGE COAT OF ARMS (COLOURED) ON THE FRONT PAGE AND AN INSCRIPTION OF THE FORMER OWNER RAINER DE ALBER'TIS OF FLORENCE. A'T END ARE SEVERAL LEAVES WITH MANUSCRIPT $\wedge$ OTES AND RECIPES, AND AN INDEX TO THE VOLUME.

Folio, original limp vellum.

Italy. XVIIth Century.

$£ 15156$

The volume is lettered at back "Practica Medicinale del P. Fra Leone Casstrucci."

84b AMATO (Domenico).

I Costumi e le Usanze de' Grecl.

ITALIAN MANUSCRIPT ON PAPER OF THE XVIIth CENTURY.

Thick folio, half bound.

$£ 55 s$

This (original and unpublished?) manusoript treats of the religions customs, theatres, national and political economy of ancient Greeks in a very interesting way. 


\section{Plate XLV.}

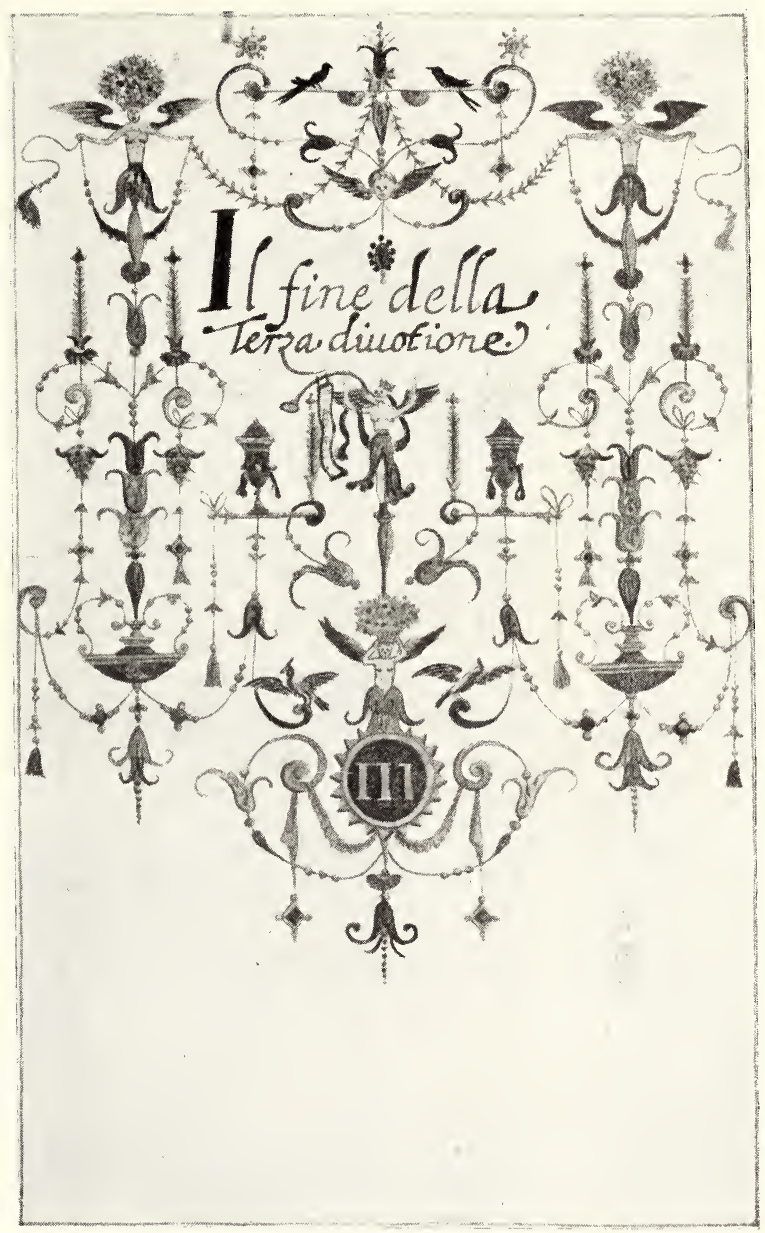

A tail-piece from Divotioni SplRituali.

Italian Mystical MS. on 194 leaves of paper. With 68 dainty emblematic Miniatures. Italy, 1611-1613.

See Item No. 84. 


\section{Plate XLVI.}

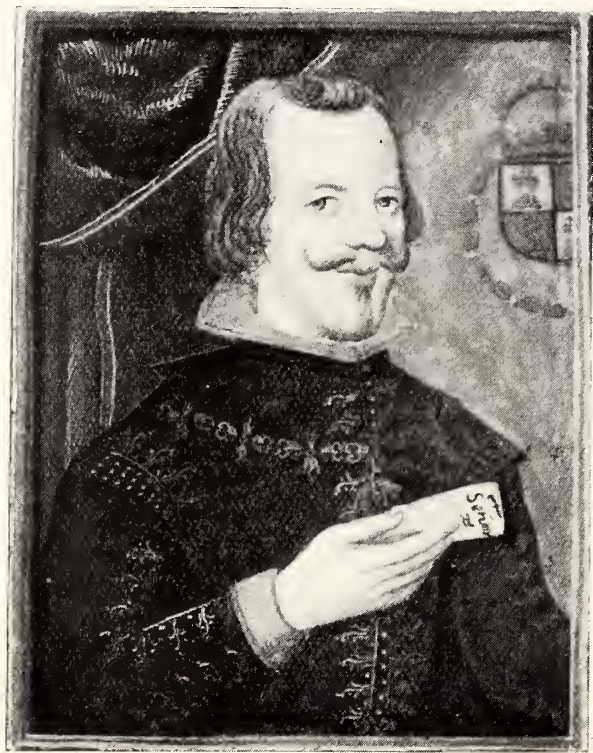

Portrait of King Philip IV. of Spain from “ Executoria," a Royal Grant of Privilegeand Nobility to Francisco Garcia de Urrechua y Chavarria. MS. on vellum. Spain, 1648.

See Item No. 85. 
MAGGS BROS, 34 \& 35, Conduit Street, London, W.

103

\section{EXECUTORIA.}

\section{Royal Grant of Privileges and Nobility to Francisco Garcla de Urre- chua, y Chavarria, by Philip IV. King of Spain.}

SPANISH MANUSCRIPT WRITTEN ON I38 LEAVES OF VELLUM, 27 LONG LINES TO A FULL PAGE, WITH NUMEROUS ORNAMENT'AL HEADINGS IN COLOURS AND FULL-PAGE MAGNIFICENT MINIATURE AT THE BEGINNING OF THE VOLUME, SHOWING DON FRANCISCO GARCIA DE URRECHUA AND HIS TWO SONS PRAYING BEFORE THE MADONNA, BEAUTIFULLY ILLUMINATED IN GOLD AND COLOURS. WITH A FULL PAGE MINIATURE OF THE COAT OF ARMS OF T'HIS SPANISH NOBLE HANDSOMELY EMBLAZONED IN GOLD AND COLOURS. TOGETHER WITH A VERY CHARMING MINIATURE OF KING PHILIP IV. OF SPAIN.

Small folio, original binding of crimson plush, $g$. $e$.

(Valladolid, I648).

(See Illustrations, Plates Nos. XlVI. and XlVII.).

$£ 21$

85 a DENIS (Abbaye de Saint).

Denis.

Cérémonies pour la Réception et la Sepulture des Religieux de St.

MANUSCRIPT WRITTEN IN RED AND BLACK, ON VELLUM.

8vo, black morocco, with clasp.

XVIIth Century.

$£ 4$ ss

"The Abbey Church of St. Denis, two miles from the City Walls of Paris, was for twelve centuries the Burial Place of the Kings of France, and contains several magnificent royal tombs, notably those of Dagobert, Louis XII., and Anne of Brittany, Henri II., and Catherine de Medicis, and Phililbert Delorme's mausoleum of Francis I. During the Revolution the tombs and other objects of art were removed, pillaged, or destroyed, and the royal dust thrown to the winds. The red banner, or oriflame, of St. Denis became the banner of the French kings. The plain of St. Denis was the scene, 1567. of a sanguinary batt'e, when the Constable of Montmorency perished on the field."

85 b Casa de Nobili Venetiani. Offici della Serma. Sigria. Di Venetia, di dentro.

AN ITALIAN MANUSCRIPT OF THE XVIth CENTURY.

WITH I97 EMBLAZONED COATS OF ARMS.

I 2 mo, original binding. 
S6 KING SOLOMON.

\section{OcCult.}

\section{La Clavicule Magique et Cabalistique du Roi Sage Solomon.}

NEATLY WRITTEN MANUSCRIPT IN FRENCH ON 302 PAGES

OF PAPER. WITH NUMEROUS MAGICAL FIGURES, PENTACLES, CHARMS, etc.

4to, original calf.

(Paris. About 1650).

$£ 1010 s$

87 RITUS Admittendi Virgines ad Habitum, Recipiendi Novitias ad Professionem \& Tradendi Velamina Jam Professis Secundum Moniales S. Laurentii Venetiarum, quos Reverendissima D.D. Caecilia Cornelio, Abbatissa, Expurgare, Instaurare et Rescribere Fecit.

MANUSCRIPT, 66 pp. ON VELLUM (9 by $6 \frac{1}{2}$ INCHES), BEAUTIFULLY WRITTEN IN LARGE ROMAN LETTERS, RED AND BLACK, WITHIN GILT BORDERS.

4to, contemporary Tenetian binding of red morocco, sides most elaborately gold tooled with figures, floral designs, stars, etc.

(Venice, I 700).

$£ 1414 s$

The Manuscript used at the ceremony of taking the veil and entering the Convent of

St. Lawrence at Venice, written by order of the Lady Abbess Cecilia.

FACETIOUS FRENCH POETRY.

\section{RECUEIL DE DIFFERENTES PIECES DE POESIE.}

A MOST EXTENSIVE AND IN'TERESTING COLLECTION OF POETRY, ORIGINAL MANUSCRIPT, BEAUTIFULLY WRITTEN', CONTAINING UPWARDS OF 200 SEPARATE PIECES OF FRENCI POETRY, 5 I 8 pp. RULED WI'TH RED LINES, “ EX LIBRIS ARMAND, CHEVALIER" ON 'TTTLE.

4to, full contemporary calf, full gilt back, red edges.

(France, XVIIIth Century).

$£ 6$ 15s

\section{8a CHIROMANCY.}

De Chiromantia tractus; de Punctis in Unguibus, de Albis in Pollice.

XVIIth CENTURY MANUSCRIPT CLEARLY WRITTEN ON I79 pp., WITH NUMEROUS DRAWINGS OF THE HAND AND ITS VARIOUS MARKINGS AND MEASUREMENTS.

$8 \mathrm{vo}$, original vellum. 


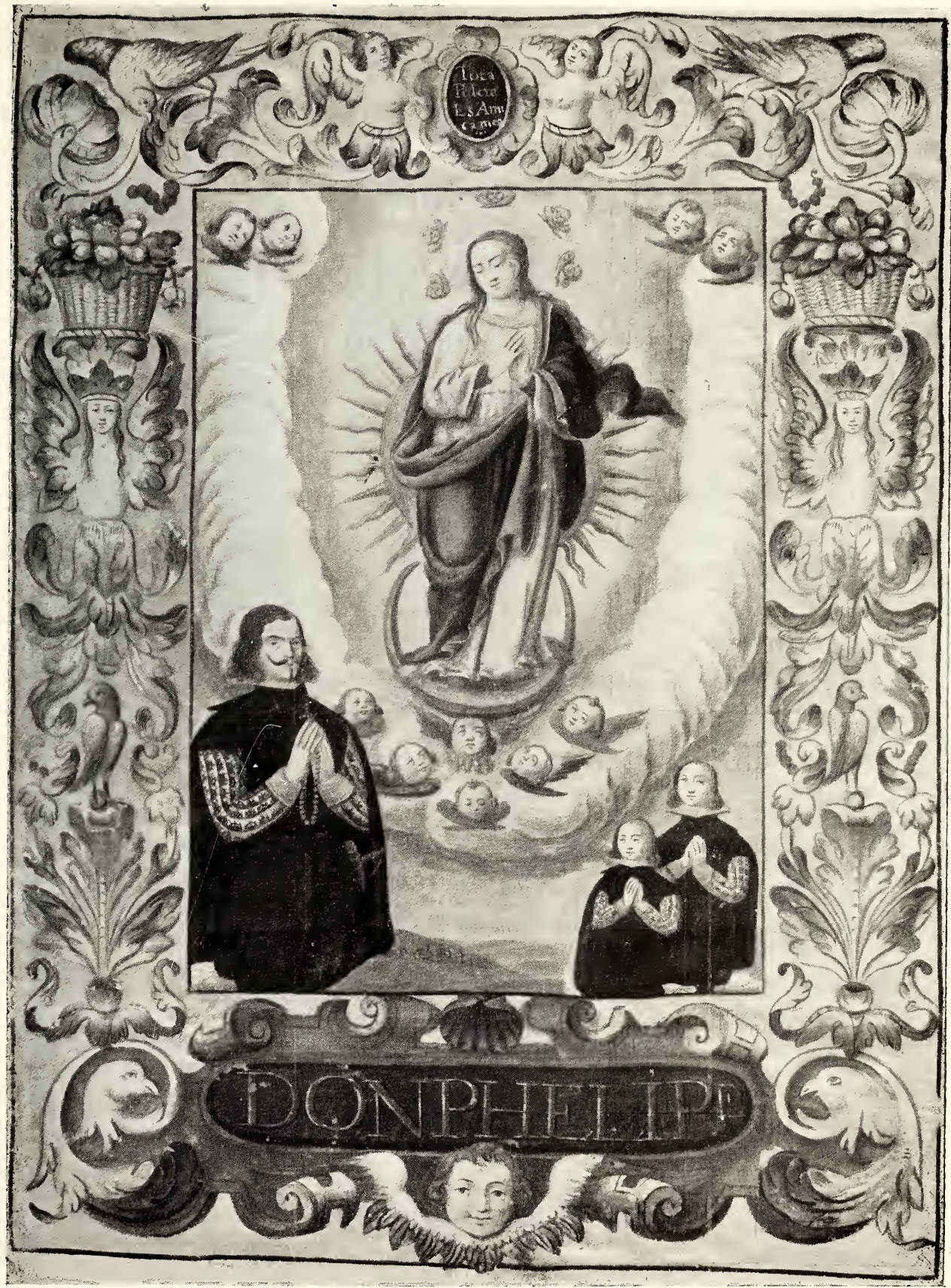

Opening Miniature from “Executoria.” Royal grant of Privilege. Valladolid, 1648.

See Item No. 85. 
Plate XLVIII.

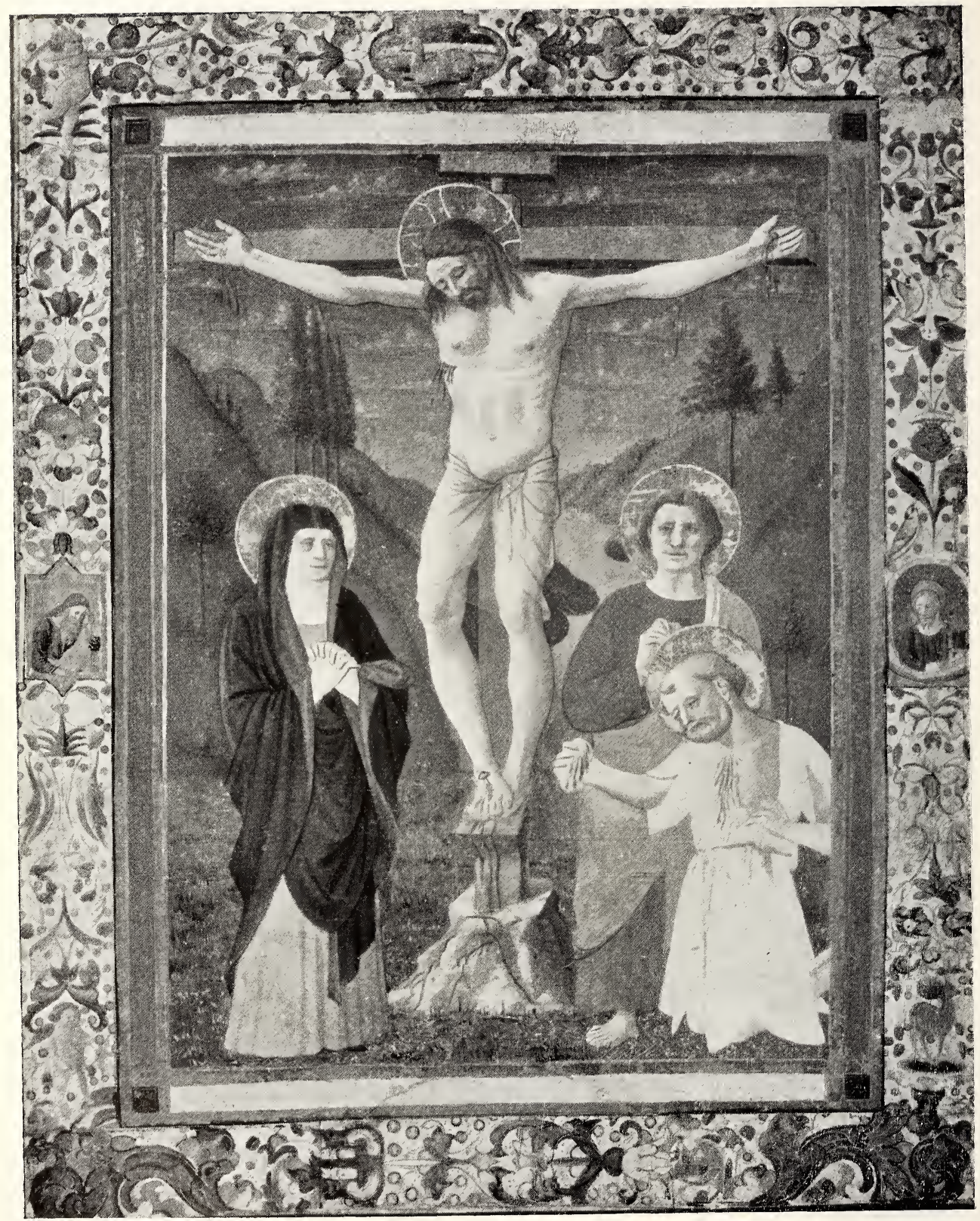

The Crucifixion. Miniature on vellum.

Italy. Early XIVth Century

See Item No. 89. 
MAGGS BROS., $34 \&$ 35, Conduit Street, London, W.

\section{PART II.}

\section{Illuminated Miniatures from European MSS.}

Superb italian Fourteenth Century Crucifixion.

sg THE CRUCIFIXION.

MAGNIFICENT MINIATURE ON VELLUM BEAUTIFULIY ILLUMINATED IN GOLD AND COLOURS, IN WHICH BLUE, BROWN AND GREEN PLAY A PREDOMINANT PART, BY AN ITALIAN ARTIST OF THE EARLY XIVth CENTURY. THE PAINTING IS SURROUNDED BY A FINELY PAINTED BORDER IN GOLD AND COLOURS, WITH ADORNMENT OF FLOWERS, CHERUBS, ANIMALS, BIRDS, etc., IN HEAVY BLACK AND GOLD WOODEN FRAME.

(MEASURING IO $\frac{1}{2}$ by $8 \frac{3}{4}$ INCHES.)

(Italy. Early XIVth Century).

(See Illustration, Plate No. Xlvili.).

$£ 5210 \mathrm{~s}$

go INITIAL S.

ARTISTICALLY PAINTED MINIATLRE ON VELLUM OF THE VIRGIN IN GREY HOLDING THE INFANT (DRESSED IN SALMON PINK GARMENTS), ON A BACKGROUND OF GREEN AND RED, WITHIN THE LETTER S. THE MINIATURE MEASURES $6 \frac{1}{2}$ by 4 INCHES, AND IS ON AN ENTIRE MAGNIFICENTLY WRITTIEN ANTIPHONAL VELLUM LEAF.

(MEASURING 20 by 13 INCHES).

(Italy. About I420).

$£ 1414 \mathrm{~s}$

9I INITIAL $B$.

DELIGHTFULLY PAINTED MINIATURE ON VELLUM OF SAINT NICOLAS IN HIS ECCLESIASTICAL ROBES, WITH A HALO, STANDING ON A PINK FLOOR WITH A BLUE BACKGROUND, WITHIN A GREEN LETTER B. THE WHOLE ON A BACKGROUND OF BURNISHED GOLD. THE MINIATURE MEASURES 4 by $3.1 \%$ INCHES, AND IS ON AN ENTIRE MAGNIFICEN'TLY WRITTEN AN'TIPHONAL VELLUM LEAF. (MEASURING I $2 \frac{1}{2}$ by I 3 INCHES).

(Italy. About I 440). 
Superb Italian XIVth Century Work.

\section{INITIAL LETTER A.}

BEAUTIFULLY ILLUMINA'TED MINIATURE IN GOLD AND COLOURS BY AN ITALIAN AR'TIST'. JESUS APPEARING TO THE VIRGIN AND TO THE DISCIPLES. FROM AN AN'IIPHONAL. ON VELLUM.

(MEASURING 6 by 6 INCHES).

(Italy. XIVth Century).

(See Illustration, Plate No. Xlix.).

$£ 42$

92a LETTER N.

CHARMINGLY PAINTED DECORATIVE MINIATURE ON VELLUM, JESUS APPEARING TO THE APOSTLES AFTER THL CRUCIFIXION. THE WHOLE ON A BACKGROUND OF BURNISHED GOLD WITHIN THE LETTER N.

(MEASURING 5 by 5 INCHES).

(Holland. About I450).

$£ 1212 s$

\section{SAINT FRANCIS OF ASSISSI.}

CHARMINGLY PAINTED DECORATIVE MINIATURE ON VELLUM OF ST. FRANCIS OF ASSISSI HOLUING A LILY IN HIS LEFT HAND, PREACHING TO THE BIRDS, A LITTLE DOG IS SITING IN FRONT OF HIM OFFERING HIM HIS RIGHT PAW AND A RABBIT IS APPEARING FROM ITS HOLE: WITHIN DECORATIVE BORDER, WHEREIN FIGURE BIRDS, DOGS AND OTHER ANIMALS. THE MINIATURE ITSELF ON BACKGROUND OF BURNISHED GOLD.

(MEASURING $4 \frac{1}{2}$ by 3 INCHES).

(Italy. About 1450). 
Plate XLIX.

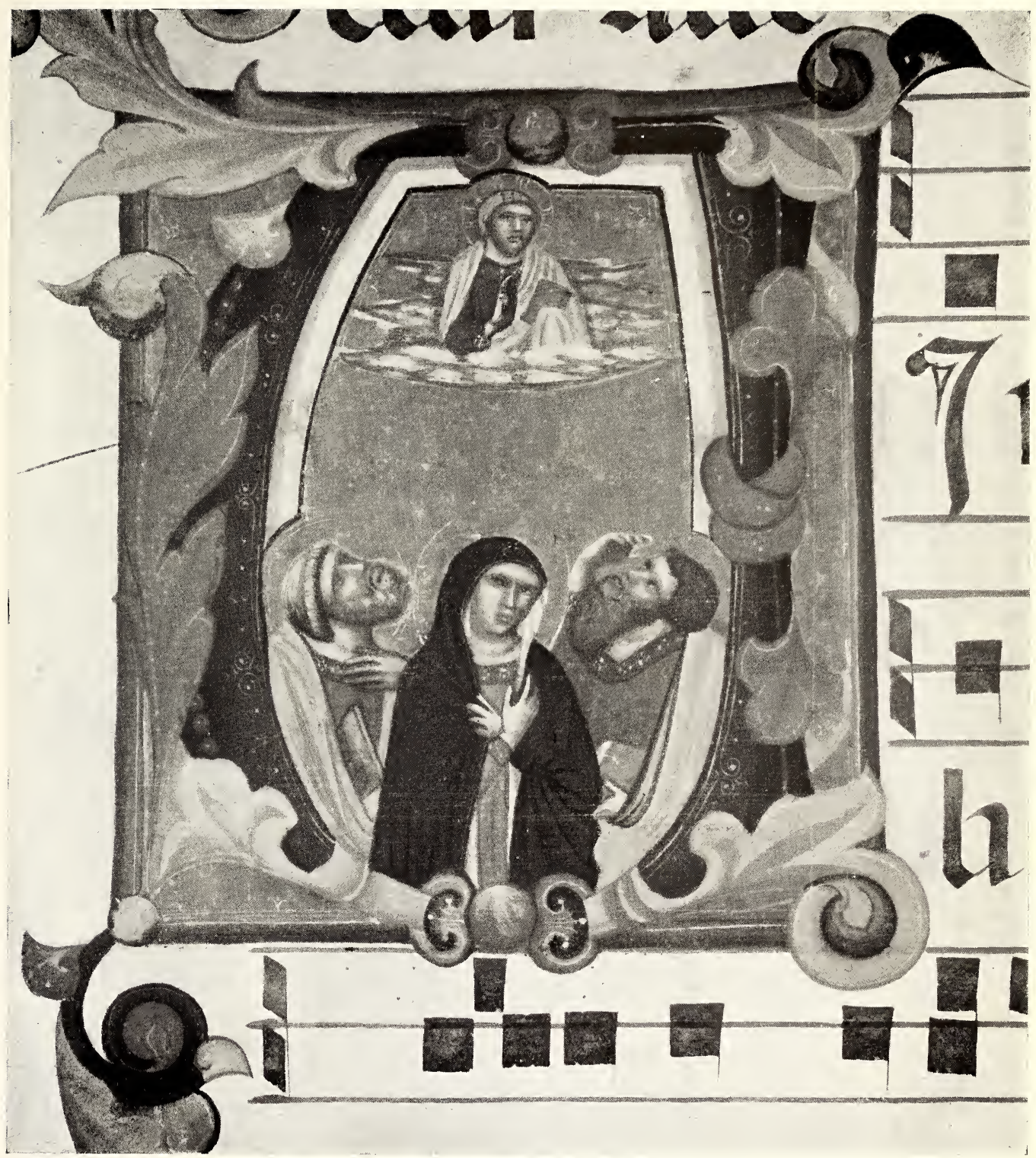

Initial A. Miniature on vellum.

Italy. XIVth Century.

See Item No. 92. 


\section{Plate L.}

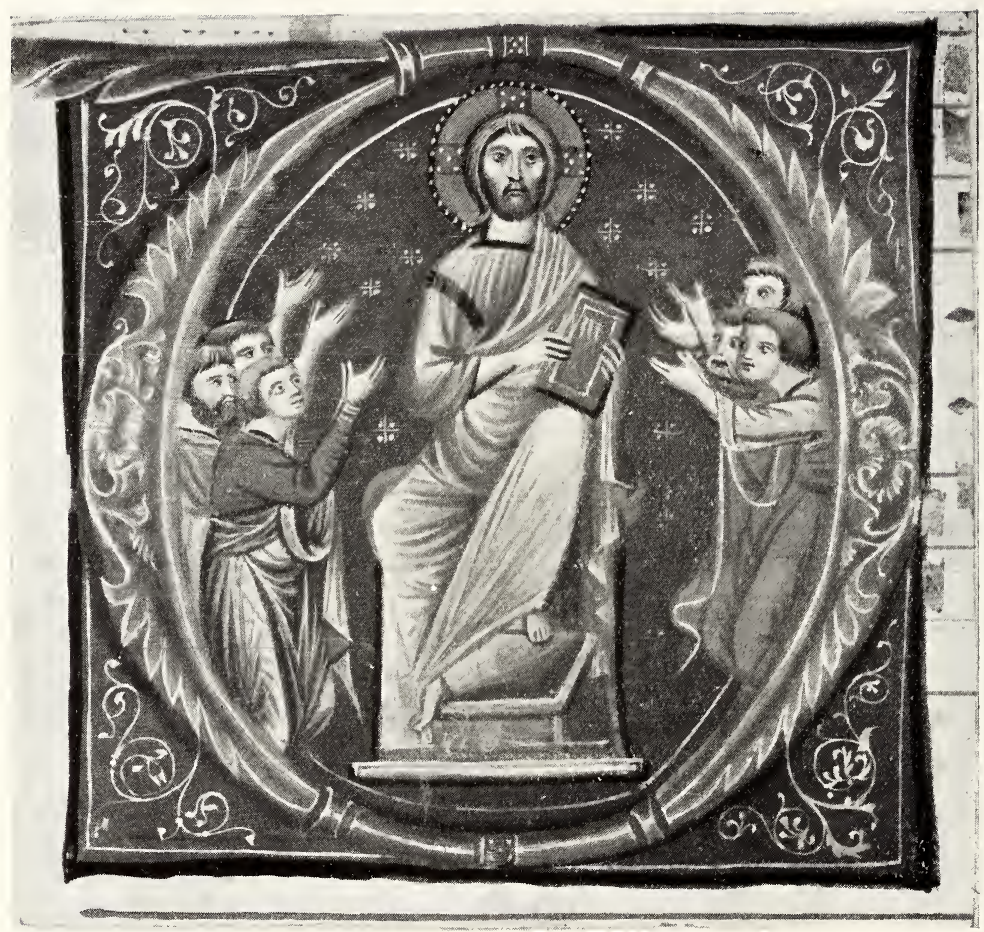

Initial O. Miniature on vellum. Italy. XIVth Century.

See Item No. 94. 
MAGGS BROS., 34 \& 35, Conduit Street, London, W.

JESUS ENTHRONED, DRESSED IN RED, ON A GREENISH MARBLE THRONE, AGAINST A BLUE BACKGROUND, WITH WHITI ORNAMENTS. ON EACH SIDE ARE THREE MEN PRAYING. SUPERBLY ILLUMINATED MINIATUKE ON VELLUM. FROM AN ANTIPHONAL.

(MIEASURING $5 \frac{1}{\frac{1}{4}}$ by $5 \frac{1}{2}$ INCHES).

(Italy. XIVth Century).

(See Illustration, Plate No. L.).

$£ 1210 s$

\section{INITIAL A.}

CHARMINGLY PAIN'TED DECORATIVE MINIATURE ON VELLUM OF JESUS BEING ADORED BY TWO SAIN'T'S IN A VERY CURIOUS CORACLE SHAPED WOODEN BOAT WITH A PADDLE AFFIXED. AT BACK IS A PRETTY LANDSCAPE CONSISTING OF A CHURCH, MOUNTAIN AND A TREE. THE WHOL.E ON A BACKGROUND OF BURNISHED GOLD, WITHIN LET'TER A.

(MEASURING $5 \frac{1}{2}$ by 5 INCHES).

(Holland. About I 450).

$£ 15$

96 INITIAL U.

CHARMINGLY PAINTED DECORATIVE MINIATURE ON VELLUM OF THE ASCENSION OF JESUS. PAINTED ON A BACKGROUND OF GOLD. WITHIN LETTER U.

(MEASURING 5 by 5 INCHES).

(France. About I450).

$£ 1212 \mathrm{~s}$

97 THE CORONATION OF THE VIRGIN.

CHARMINGLY PAINTED MINIATURE ON VELLUM. WITH INITIAL LET'TER IN GOLD AND COLOURS AND A FEW LINES OF TEXT. FROM A PARISIAN BOOK OF HOURS.

(MEASURING $6 \frac{1}{2}$ by $4 \frac{1}{2}$ INCHES).

(Paris. About I450). 

MAGGS BROS., 34 \& 35, Conduit Street, London, W.

\section{INITIAL 0.}

* JESUS APPEARING TO AN OLD MAN. HE IS SUPPORTED BY TWO ANGELS, DRESSED IN GREEN AND PINK, THE ANGELS HAVE FACES THE COLOUR OF TERRA-COT'TA. THE MINIATURE, BEAUTIFULLY PAINTED ON VELLUM, HAS A DARK BLUE BACKGROUND WITHIN INITIAL O. THE WHOLE ON A BACKGROUND OF BURNISHED GOLD.

(MEASURING $3 \frac{1}{4}$ by $3 \frac{1}{x}$ INCHES).

(Italy. XVth Century).

(See Illustration, Plate No. Li.).

$£ 1010$ s

99 THE ARREST OF JESUS.

CHARMINGLY PAINTED MINIATURE ON VELLUM. WITH INITIAL IN GOLD AND COLOURS AND A FEW LINES OF TEXT. FROM A PARISIAN BOOK OF HOURS.

(MEASURING $6 \frac{1}{2}$ by $4 \frac{1}{2}$ INCHES).

(Paris. About 1450).

$£ 55 s$

IOO SAINT HUBERT AND THE STAC.

CHARMINGLY PAINTED MINIATURE ON VELLUM. WITII INITIAL LET TER IN GOLD AND COLOURS AND A FEW LINES OF TEXT. FROM A PARISIAN BOOK OF HOURS.

(MEASURING $6 \frac{1}{2}$ by $4 \frac{1}{2}$ INCHES).

(Paris. About 1450).

$£ 55 s$

IOJ. THE NATIVITY.

CHARMINGLY PAINTED MINIATURE ON VELLUM. WITH INITIAL LETTER IN GOLD AND COLOURS AND A FEW LINES OF TEXT. FROM A PARISIAN BOOK OF HOURS.

(MEASURING $6 \frac{1}{2}$ by $4 \frac{1}{2}$ INCHES).

(Paris. About I450.)

$£ 55 s$

102 THE VISITATION.

CHARMINGLY PAINTED MINIATURE ON VELLUM. WITH INITIAL LETTER IN GOLD AND COLOURS AND A FEW LINES OF 'TEXT. FROM A PARISIAN BOOK OF HOURS.

(MEASURING $6 \frac{1}{2}$ by $4 \frac{1}{2}$ INCHES.)

(Paris. About I450.) 


\section{Plate LI.}

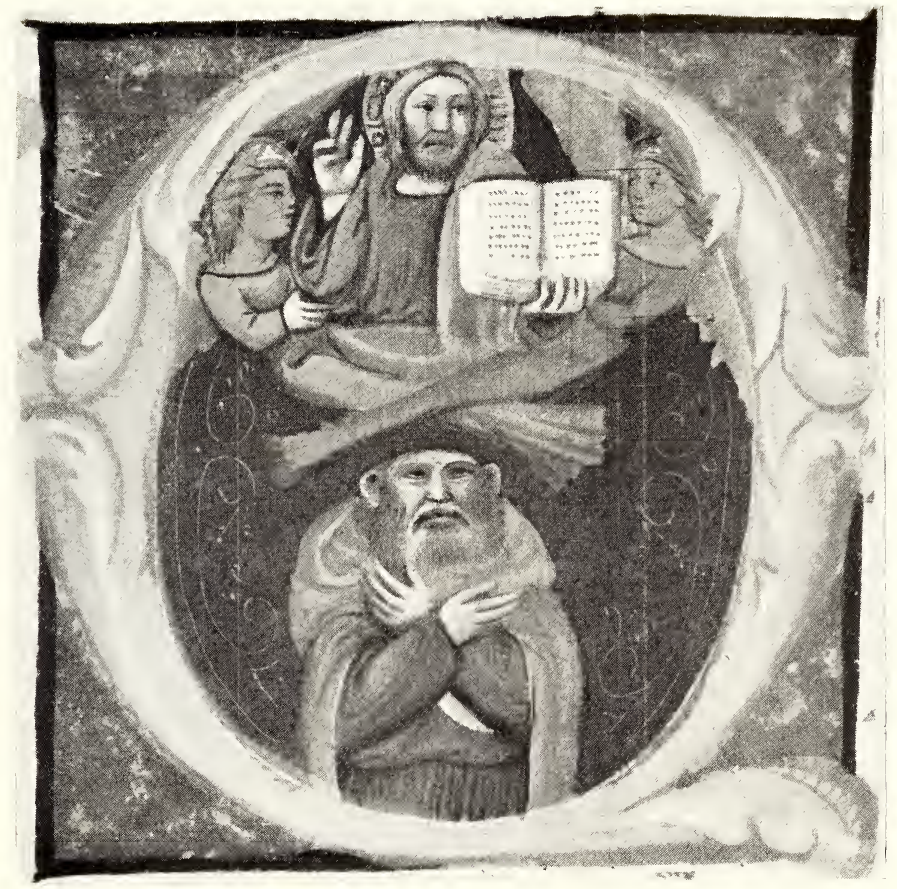

Initial O. Miniature on vellum.

Italy. XVth Century.

See Item No. 98. 
Plate LII.

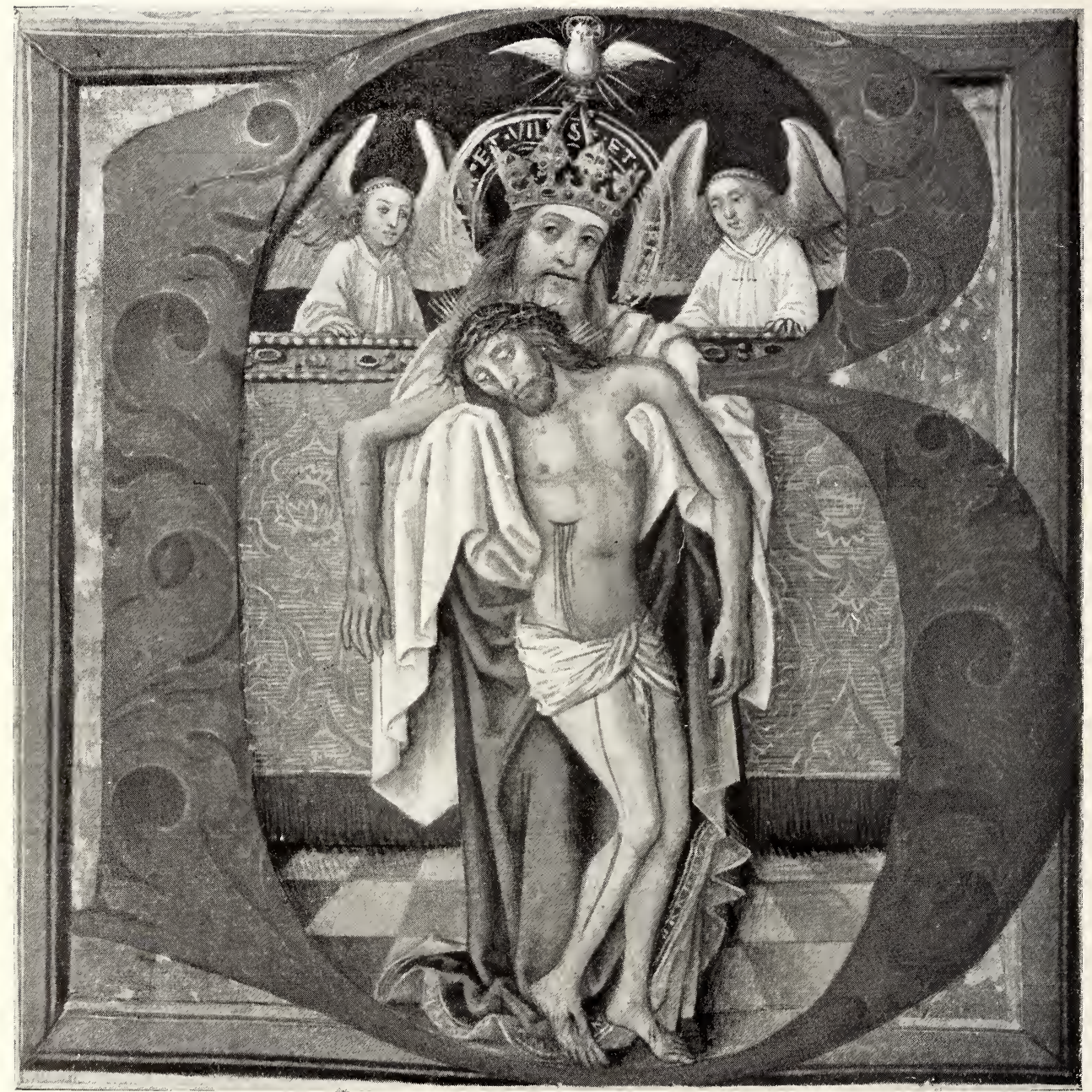

Initial B. Magnificently painted Miniature on vellum of "The Trenstr." Painted by a Flemish Master of the School of Van Eyck.

Flanders. Early XVth Century.

See Item No. 103. 
MAGGS BROS., 34 \& 35, Conduit Street, London, W.

MAGNIFICENTLY PAINTED MINIATURE ON VELLUM OF THE TRINITY, WITHIN A LETTER B. PAINTED BY A FLEMISH MASTER OF THE SCHOOL OF VAN EYCK. THE COLOURS AND EXPRESSIONS ARE MAGNIFICENTLY RENDERED, THE WHOLE BEING ON A BACKGROUND OF FINELY BURNISHED GOLD, WITH A GREEN MARGIN. THE LETTER B ITSELF BEING RED, AND ADORNED WITH FLORAL ORNAMENTS. FLEMISH SCHOOL.

(MEASURING 6 by 6 INCHES).

(Flanders. Early XVth Century).

(See Illustration, Plate No. LiI.).

$£ 5210 \mathrm{~s}$

104 THE LAST JUDGMENT.

CHARMINGLY PAINTED MINIATURE ON VELLUM. WITH INITIAL LETTER IN GOLD AND COLOURS AND A FEW LINES OF TEXT. FROM A PARISIAN BOOK OF HOURS.

(MEASURING $6 \frac{1}{2}$ by $4 \frac{1}{3}$ INCHES).

(Paris. About I 450.)

$£ 55 s$

IO5 THE ANNUNCIATION.

CHARMINGLY PAINTED MINIATURE ON VELLUM. WITH INITIAL LETTER IN GOLD AND COLOURS AND A FEW LINES OF TEXT. FROM A PARISIAN BOOK OF HOURS.

(MEASURING 6 $\frac{1}{2}$ by $4 \frac{1}{2}$ INCHES.)

(Paris. About I450.)

£5 5s

\section{I06 THE ADORATION OF THE MAGI.}

CHARMINGLY PAINTED MINIATURE ON VELLUM. WITH INITIAL LETTER IN GOLD AND COLOURS AND A FEW LINES OF TEXT. FROM A PARISIAN BOOK OF HOURS.

(MEASURING $6 \frac{1}{2}$ by $4 \frac{1}{2}$ INCHES.)

(Paris. About I45O.) 
IO7 INITIAL T.

BEAUTIFULLY PAINTED MINIATURE ON VELLUM OF THE ADORATION OF THE MAGI BY AN ITALIAN ARTIST. THE KINGS RICHLY GARBED, TWO OF THEM BEING IN ARMOUR. AT BACK IS A SCENE OF THE KINGS WITH THEIR CARAVANS OF CAMELS AND MULES BEING ATTRACTED BY THE STAR OF BETHLEHEM. THE WHOLE ON A BACKGROUND OF BURNISHED GOLD WITH ADDI'TIONAL FLORAL ORNAMENTS.

(MEASURING $6 \frac{1}{4}$ by $6 \frac{1}{2}$ INCHES).

(Italy. About A.D. I 4.80 ).

(See Illustration, Plate No. LiII.).

$£ 35$

IO8 THE OFFICE FOR THE DEAD.

CHARMINGLY PAINTED MINIATURE ON VELLUM. WITH INITIAL LET'TER IN GOLD AND COLOURS AND A FEW LINES OF 'TEXT. FROM A PARISIAN BOOK OF HOURS.

(MEASURING $6 \frac{1}{2}$ by $4 \frac{1}{2}$ INCHES.)

(Paris. About I450.)

$£ 55 s$

IOG THE ANNUNCIATION OF THE SHEPHERDS.

CHARMINGLY PAINTED MINIATURE ON VELLUM. WITH INITIAL LETTER IN GOLD AND COLOURS AND A FEW LINES OF TEXT. FROM A PARISIAN BOOK OF HOURS.

(MEASURING $6 \frac{1}{2}$ by $4 \frac{1}{2}$ INCHES.)

(Paris. About I450.)

$£ 55 s$

I IO THE CRUCIFIXION.

CHARMINGLY PAINTED MINIATURE ON VELLUM. WITH INITIAL LETTER IN GOLD AND COLOURS AND A FEW LINES OF TEXT. FROM A PARISIAN BOOK OF HOURS.

(MEASURING $6 \frac{1}{2}$ by $4 \frac{1}{2}$ INCHES.)

(Paris. About I 450 .)

$£ 5$ s

I IOa ANTIPHONAL LEAF.

BEAUTIFULLY WRITTEN LEAF ON VELLUM FROM AN ANTIPHONAL WITH MUSICAL NOTATION, WITH A LARGE INITIAL M IN BLUE ON A BACKGROUND OF GOLD (MEASURING 4 by 4 INCHES.) AT SIDE AND BOTTOM OF THE LEAF IS A CURIOUS BORDER COMPOSED OF TWO "WILD WOMEN" ENGAGED IN CARDING WOOL AND IN. WORKING THE DISTAFF. A WEIRD GREEN DRAGON IS LOOKING ON WITH CONTEMPT. ON THE EXTREME RIGHT A BEAUTIFULLY DRAWN PEACOCK TURNS HIS BACK ON THEM.

(MEASURING 20 by 14 INCHES.)

(Bohemia. About 1480.) 
Plate LiII.

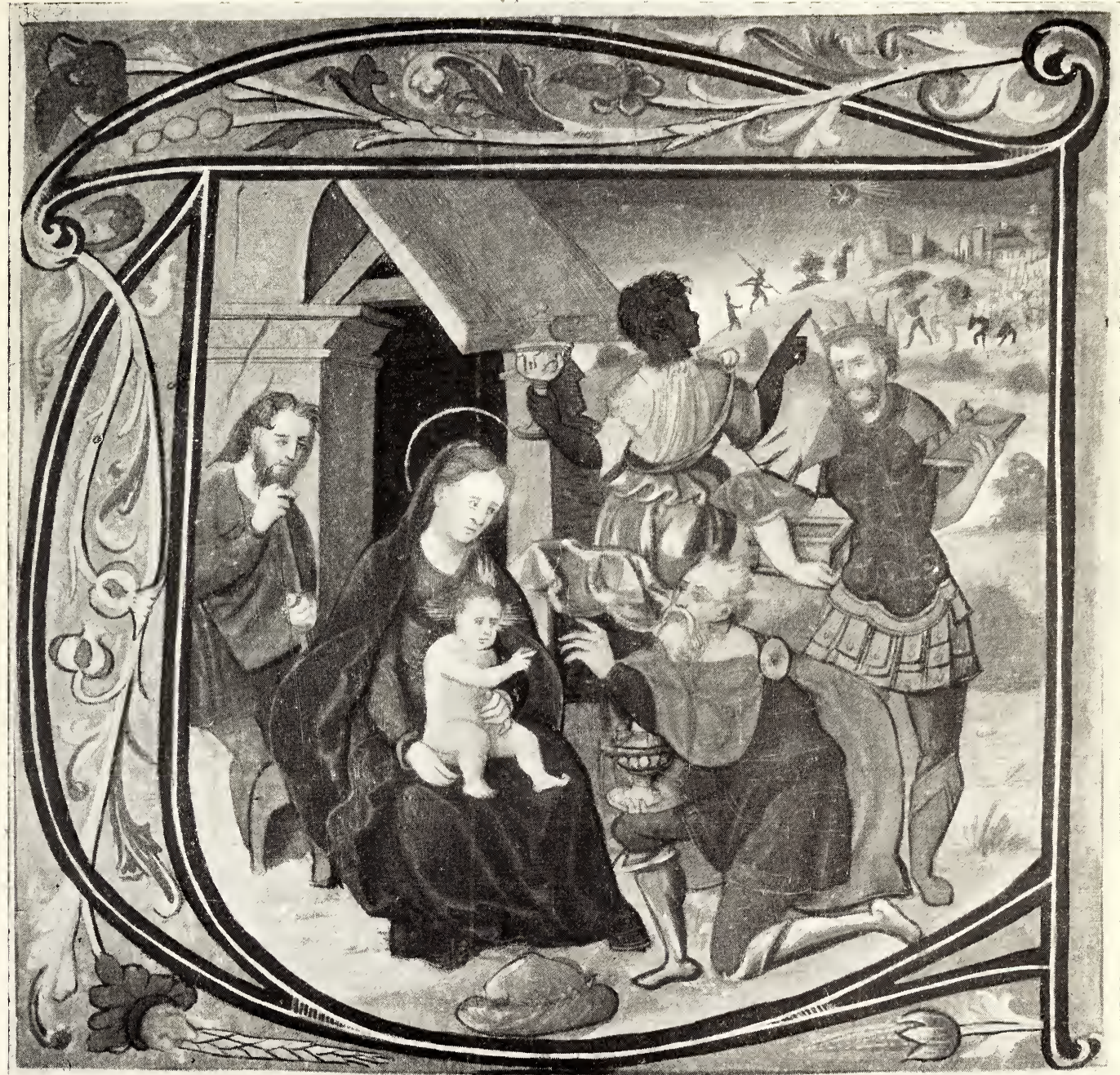

Initial T. Miniature on vellum of "The Adoration of the Migi." Painted by an Italian Artist. Italy, about A.D. 1480. See Item No. 107 . 


\section{Plate LIV.}

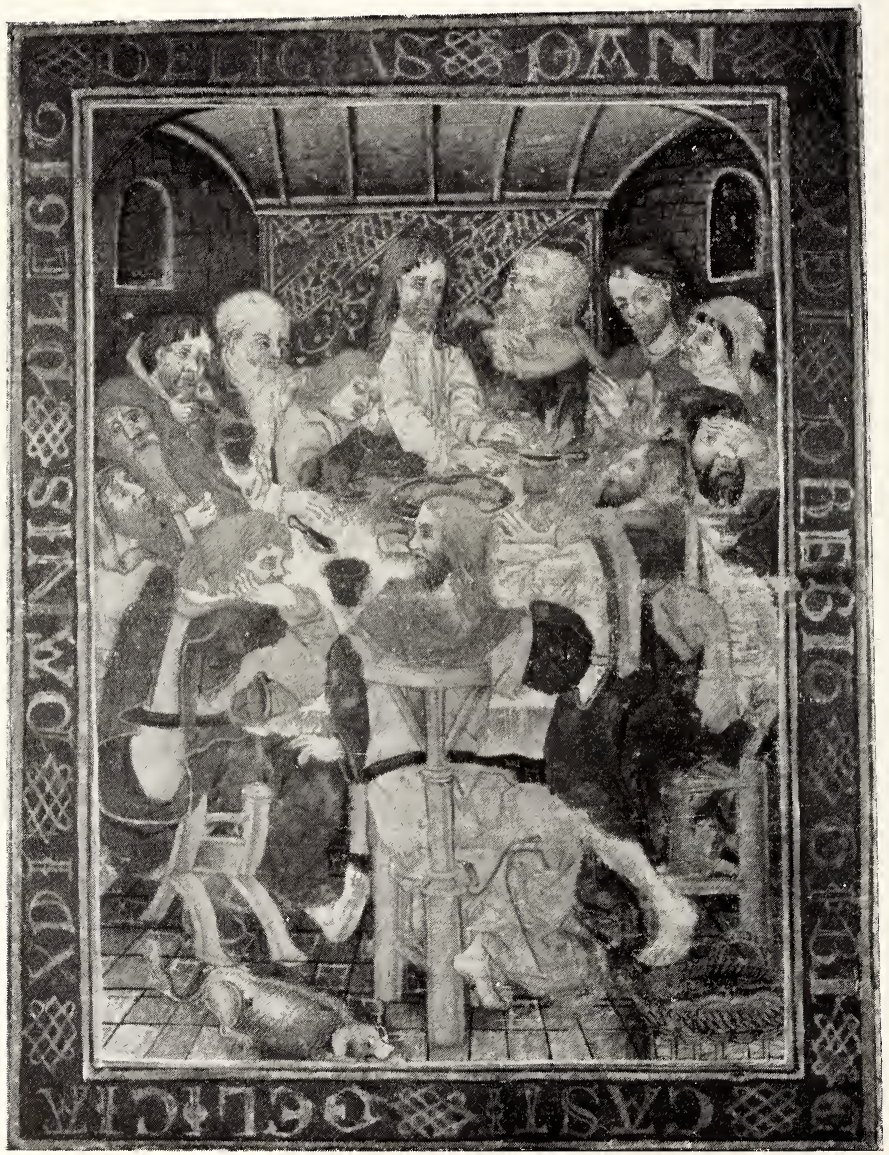

"The Last Supper." Miniature on vellum.

Cleves, about 1400 .

See Item No. 111. 
MAGGS BROS., 34 \& 35, Conduit Street, London, W.

\section{THE LAST SUPPER.}

DELIGHTFULLY DRAWN MINIATURE IN COLOURS HEIGHT'ENED WITH GOLD OF THE LAST SUPPER. JESUS IN THE MIDST OF THE TWELVE DISCIPLES, ALL OF WHOM ARE CAREFULLY CHARACTERIZFD. THE FURNITURE IS OF GREAT INTEREST' AND THE ROBES ARE ALL CAREFULLY PAINTED. ON VELLUM.

(MEASURING $6 \frac{1}{4}$ by $4^{\frac{3}{4}}$ INCHES).

(Cleves. About I400).

(See Illustration, Piate No. LiV.).

$£ 2710$ s

\section{2 ANTIPHONAL LEAF.}

BEAUTIFULLY WRITTEN LEAF ON VELLUM FROM ANTIPHONAL WITH MUSICAL NOTATION, WITH A LARGE INITIAL O ON A BACKGROUND OF GREEN. (MEASURING 4 by 4 INCHES.) AT SIDE AND BO'TTOM OF LEAF IS A CURIOUS BORDER COMPOSED OF BIRDS AND ORNAMENTS AND A CURIOUS HUNTING SCENE, A WILD MAN BEING ENGAGED IN A LION FIGH'T. THE LION IS VERY REALISTICALLY DRAWN AND IS JUST' ROARING.

(MEASURING 20 by I4 INCHES.)

(Bohemia. About I480.)

$£ 66 \mathrm{~s}$

\section{3 ANTIPHONAL LEAF.}

BEAUTIFULLY WRITTEN LEAF ON VELLUM FROM ANTIPHONAL WITH MUSICAL NOTATION, WI'TH A LARGE INITIAL F ON A SILVER AND GOLD BACKGROUND. (MEASURING 4 by 4 INCHES). A'T SIDE OF LEAF A CURIOUS BORDER COMPOSED OF SIX LARGE BIRDS AND FLORAL ORNAMENTS IN GOLD AND COLOURS. THE BIRDS ARE VERY REALISTICALLY DRAWN.

(MEASURING 20 by I 4 INCHES.)

(Bohemia. About I48o.) 


\section{I 4 ANTIPHONAL LEAF.}

BEAUTIFULLY WRITTEN LEAF ON VELLUM FROM ANTIPHONAL WITH MUSICAL NOTATION, WITH A LARGE INITIAL O CONTAINING A PICTURE OF THE VIRGIN AND CHILD, ON A BACKGROUND OF SOLID BURNISHED GOLD. (MEASURING $3 \frac{3}{4}$ by $4 \frac{1}{2}$ INCHES). AT SIDE OF LEAF A CURIOUS ORNAMENTAL FLORAL BORDER IN GOLD AND COLOURS.

(MEASURING 20 by I4 INCHES.)

(Bohemia. About I480.)

$£ 710$ s

\section{I 5 DECORATIVE LEAF.}

BEAU'TIFULLY PAIN'TED LEAF ON VELLUM, WITH BORDER SURROUNDING 2 I LINES OF HANDSOMELY WRIT'TEN GOTHIC CHARAC'TERS. THE BORDER, WHICH IS CHARMINGLY PAIN'TED ON A BACKGROUND OF PURE WHITE, COMPRISES REALISTICALLY PAINTED FLOWERS IN DAIN'TY COLOURS, A SUPERCILIOUS PEACOCK, SOME TEMPTING STRAWBERRIES. ON THE REVERSE OF THE LEAF IS A SIMILAR BORDER PAINTED WITH GREAT RESTRAIN'T IN GOLD AND COLOURS AT THE BO'TTOM OF WHICH A CIVILISED MAN WITH SHIELD AND CLUB IS FIGHTING A WILD MAN WHO HAS NOTHING BUT A CLUB AND A BLUE FLOWER OF ROMANTICISM WI'TH WHICH TO DEFEND HIMSELF.

(MEASURING I 4 by io $\frac{1}{2}$ INCHES.)

(Italy. About I 500).

$£ 1010$ s

\section{II6 DECORATIVE LEAF.}

BEAUTIFULLY PAINTED LEAF ON VELLUM WITH BORDER SURROUNDING 2I LINES OF HANDSOMELY WRITTEN GOTHIC CHARACTERS AND TWO HISTORIATED INITIAL LET"TERS. THE BORDER, WHICH IS CHARMINGLY PAINTED IN GOLD AND COLOURS ON A BACKGROUND OF DARK BLUE, COMPRISES THE EMBLEMS OF THE PASSION', HEADS OF SAINTS, SAIN'T VERONICA'S HANDKERCHIEF, ETC., ETC. ON THE BACK IS A SIMILAR BORDER WHICH IS ENTIRELY COMPOSED OF REALISTIC FLORAL ORNAMENT.

(MEASURING 14 by IO $\frac{1}{2}$ INCHES.)

(Italy. About I 500.) 
MAGGS BROS., 34 \& 35, Conduit Street, London, W.

\section{7 THE GRUCIFIXION.}

VERY PRETTY MINIATURE ON VELLUM, WITH SIX LINES OF TEXT ON TOP AND ILLUMINATED INITIALS, AND CHARMING PAGE OF TEXT WITH TWO LARGE INITIAL LETTERS IN GOLD AND COLOURS ORNAMENTED WITH FLOWERS AND SIXTEEN SMALLER INITIALS IN GOLD AND COLOURS.

(MEASURING 4 by 4 INCHES).

(Italy. About I 500.)

$£ 1010$ s

\section{8 SAINT BARBARA AND THE TARASQUE.}

CHARMING MINIATURE ON THIN VELLUM, BEAUTIFULLY ILLUMINATED IN GOLD AND COLOURS, OF ST. BARBARA BIDDING THE TERRIBLE TARASQUE (THE DRAGON THAT RAVAGED THE SOUTH OF FRANCE) TO GIVE UP THE MAN WHOSE LEGS CLAD IN BLUE ARE PRO'TRUDING FROM I'TS JAWS.

AT BACK IS A CHARMING SOUTHERN LANDSCAPE WITH NUMEROUS CASTLES AND CHURCHES, ONE CASTLE BEING IN RUINS.

(MEASURING $6 \frac{1}{2}$ by $4 \frac{1}{4}$ INCHES).

(France. About I 520.)

$£ 1515 s$

The terrible Tarascue has given its name to Tarascon, the birthplace of Daudet's world renowned hero Tartarin.

I I ALOYSIUS GONZAGA of the Society of Jesus sees a vision of Saint Charles Borromaeus.

CHARMINGLY PAINTED SPANISH MINIATURE ON VELLUM. (MEASURING $9 \frac{3}{4}$ by 7 INCHES).

(Spain. About I 590.)

$£ 445$

\section{20 HUNTING.}

VERY DECORATIVE COAT OF ARMS SHOWING A DEER CHASF. IN FULL PROGRE,SS. PAINTED IN GOLD AND COLOURS ON VELLUM.

(MEASURING $4 \frac{1}{2}$ by 4 INCHES.)

(About i650.)

$£ 3$ 10s 


\section{PART III. \\ Oriental Manuscripts.}

\section{ARABIC.}

Seventh Century Manuscript on Vellum of the Koran, the Sacred Book of Islam, in Cufic Characters, from Medina.

\section{I2I KORAN.}

A MAGNIFICENT MANUSCRIPT OF PORTION OF THE KORAN IN DEEP BLACK CHARACTERS ON 20 LEAVES OF THICK VELLUM (I2 by I $5 \frac{1}{2}$ INCHES), BEAUTIFULLY WRITTEN IN ARABIC ON I3 LONG LINES TO A PAGE IN CUFIC LETTERS, THE OLDEST OR SQUARE ARABIC CHARACTERS, ORTHOGRAPHIC MARKS IN RED.

Large oblong folio, red Oriental blind stamped leather.

(Arabia. Middle of VIIth Century).

Early Korans are greatly treasured in the East and especially MSS. written on vellum. No complete early Vellum MIS. of the Koran is' known to us to be in existence at the present day.

There are several very interesting ornamental designs in colours, yellow, black, and red and green in this MS. which are of great interest for the history of Oriental Ornament and design.

Originally the property of "a Mosque in Arabia. (Each page bears the word "wakf," "sacred property.") Afterward in the possession of a Noble Arab Family at Medina, where it had been for sereral hundred years.

Eighth Century Manuscript on Vellum of the Koran.

I22 KORAN. Part of the Koran.

MANUSCRIPT IN ARABIC IN THE ANCIENT SQUARE OR CUFIC CHARACTER ON.6O LEAVES OF THICK VELLUM. WITH A FINE ORNAMENTAL HEADLINE AND DESIGN IN GOLD AND COLOURS, ONE LINE BEING ENTIRELY WRITTEN IN GOLD.

WRITTEN NOT LATER THAN THE EIGHTH CENTURY.

Oblong 4to. Oriental red leather with ornamental shazel design laid in leather doublure.

(See Illustration, Plate No. LV.).

A Magnificent:Cufic Manuscript. 
Plate LV.

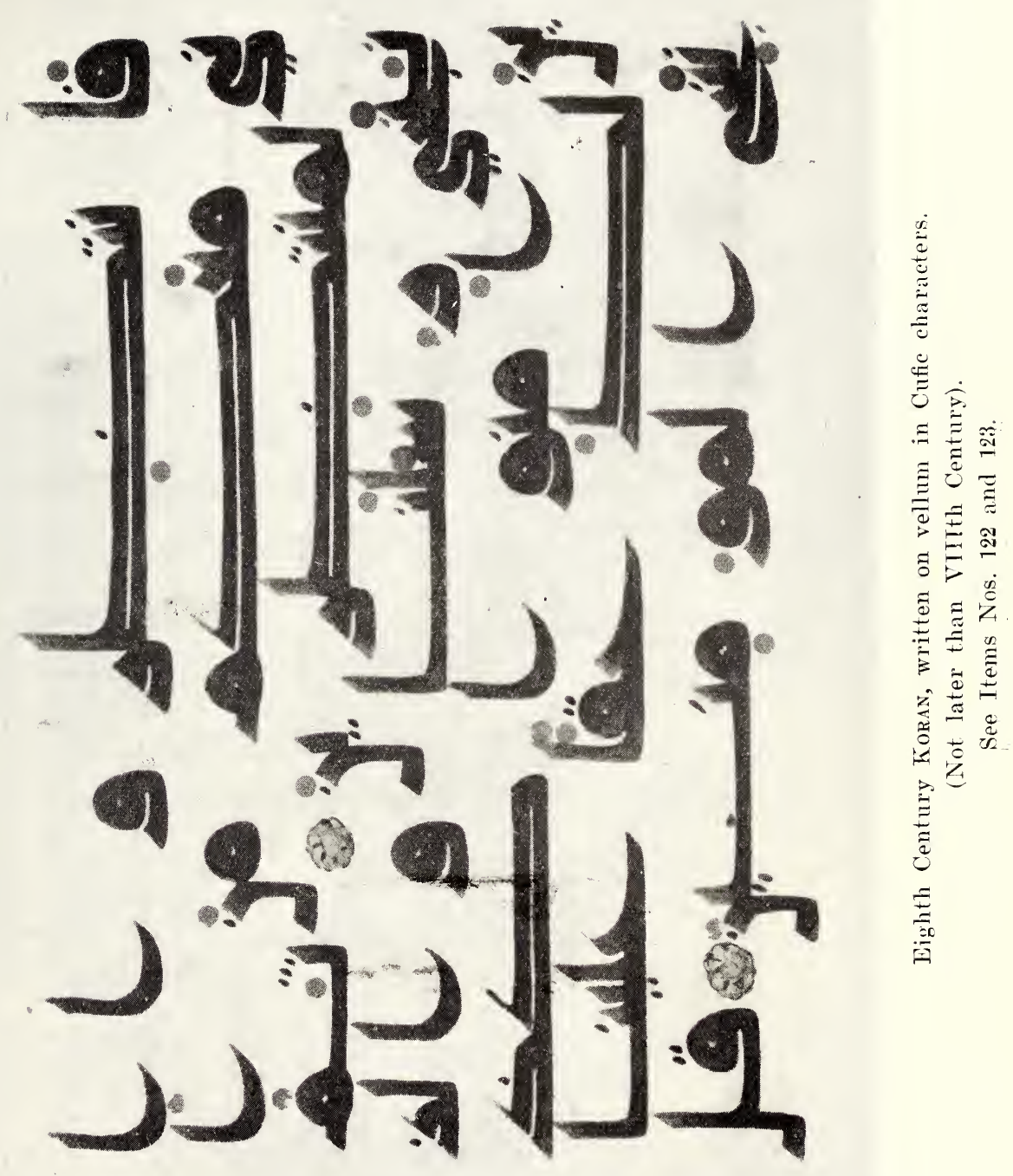


Plate LVI.

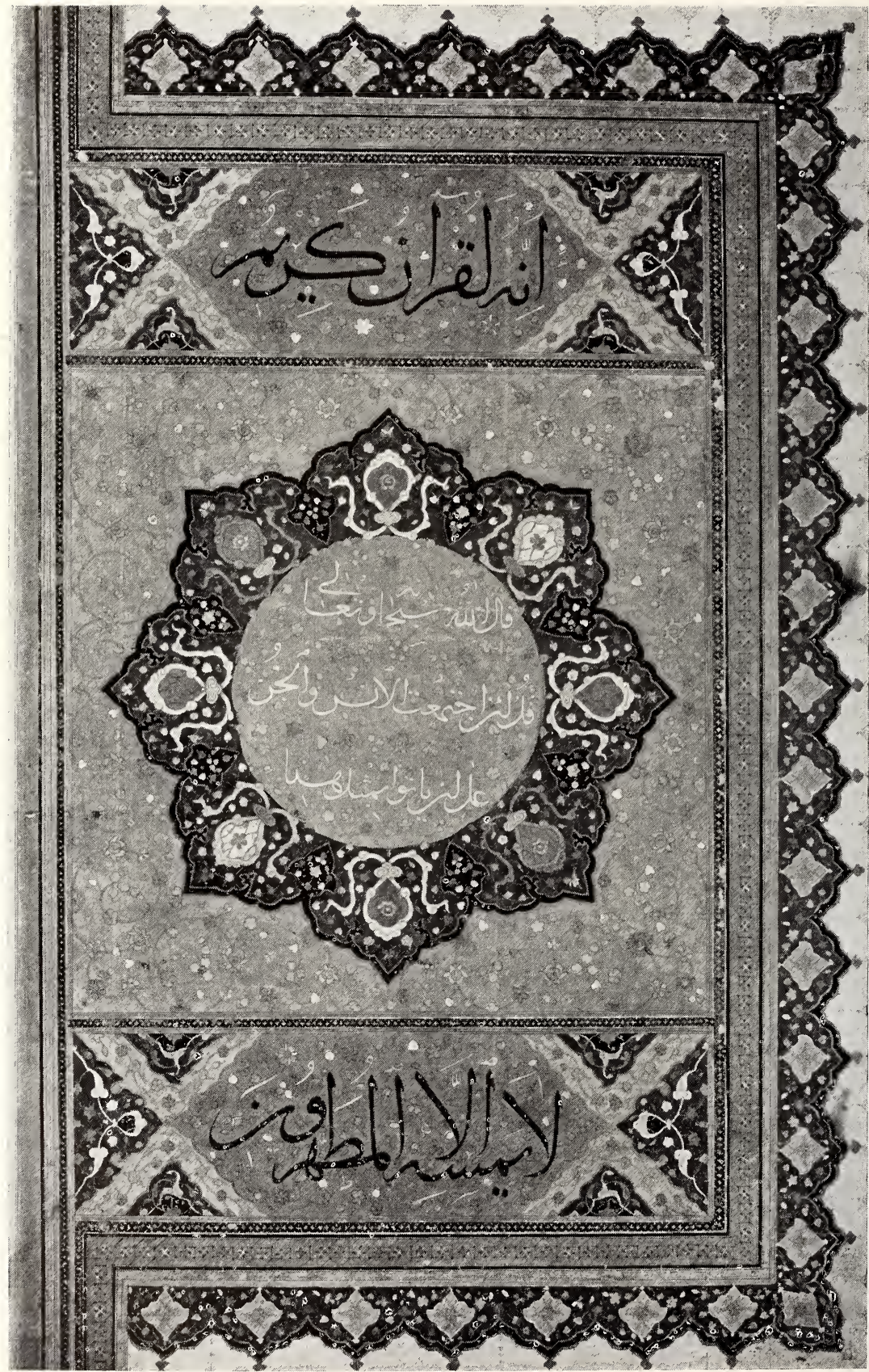

Opening page (much roduced) from magnificent manıscript of the Koran in Arabic. Written by HaJji 'Ali Inkati, of Shiraz, Persia, about a.D. 1600. See Item No. 125. 
MAGGS BROS., 34 \& 35, Conduit Street, London, W.

Arabic MSS.-continued.

Eighth Century Manuscript on Vellum of the Koran.

I 23 KORAN. Part of the Koran.

MANUSCRIPT IN ARABIC IN THE ANCIENT OR SQUARE CUFIC CHARACTERS ON 86 LEAVES OF THICK VELLUM, WITH ORNAMENTAL HEADLINES IN GOLD AND COLOURS.

WRITTEN NOT LATER THAN THE EIGHTH CENTURY.

Oblong 4to, Oriental leath:r binding, with gilt ornaments in leather case.

(See Illustration, Plate No. LV.).

$£ 608$

Stained with blood in a few places. Showing that the owner had been killed whilst with this his most sacred possession upon him.

\section{24 KORAN.}

MANUSCRIPT OF PORTION OF THE KORAN IN CUFIC CHARACIERS, SOME LINES WRI'TTEN IN GOLD, WITH GOLD SURA ENDINGS AND PUNCTUATION-MARKS IN BLUE, GREEN AND RED, ON 88 LEAVES OF VELLUM, I I LONG LINES TO A FULL PAGE.

Small 4to, Oriental binding of red calf, with flap.

(Africa. Xth Century).

$£ 50$

\section{25 KORAN.}

MAGNIFICENT MANUSCRIPT IN ARABIC, WRITTEN ON 632 PAGES OF S'IOUT PAPER IN A BEAU'TIFUL NASHKI HAND, BY HAJJI 'ALI INKATI OF SHIRAZ (PERSIA).

ACCORDING 'TO AN INSCRIP'TIO V. ON FOLIO I I THE KORAN WAS BEQUEATHED TO A RELIGIOUS COMMUNITY BY KARA MUSTAPHA PASHA. (TWO OTTOMAN DIGNITARIES OF THAT NAME ARE KNOWN. BOTH DIED IN THE XVIIth CENTURY; THE ONE A.D. I643, THE OTHER A.D. I683.)

ON FOLIOS Ib, 2a. 2b AND 3i6b ARE FOUR FULL-PAGE ILLUMINATED ANWANS WHICH MAY BE RECKONED AMONG THE MASTERPIECES OF MOSLEM ART. THE MARGINS. WHICH ARE FULL THROUGHOUT THE VOLUME, BEAR ROSETTES ILLUMINATED IN GOLD AND COLOURS ON EVERY PAGE. THE TITLES OF THE SINGLE SURAS OR CHAPTERS ARE WRITTEN IN WHITE INK ON A GOLD GROUND WITH BEAUTIFULLY ADORNED BORDERS.

Folio, Oriental binding of stamped leather, probably XVIII Centuyy Turkish work.

(Shiraz, Persia. About A.D. I600).

(See Illustration, Plate LVI.). 


\section{Arabic MSS.-continued.}

\section{26 KORAN.}

SELECTIONS FROM THE KORAN WRITTEN IN ARABIC ON 59 PAGES OF GOLD SPRINKLED PAPER WITHIN GOLD RULES, WITH ALTERNATE GOLD AND RUBRICATED LINES AND TWO MAGNIFICENTLY ILLUMINATED SARLOWS IN GOLD AND COLOURS.

Folio, gold stamped crimson morocco binding with flap.

(Dated A.D. I46r.)

$£ 31$ 10s

This is a most desirable specimen of beautiful calligraphy in excellent condition.

The gold work is uncommon in Arabic manuscripts of this period.

I 26 a KORAN.

Extraordinary Miniature Manuscrip' of the Koran.

MANUSCRIP'T OF THE KORAN IN ARABIC ON I95 LEAVES OF PAPER WRITTEN IN A.D. I634, IN A MINUTE HAND. 32mo, bound in leather. (MEASURING 2 by $\mathrm{I} \frac{3}{4}$ INCHES). (A.D. I634),

\section{$£ 1515 s$}

\section{27 AL-HARIRI.}

\section{The Famous Makamat.}

ARABIC MANUSCRIPT WRITTEN IN SINGLE COLUMN, WITHIN COLOURED RULES, ON 526 PAGES OF PAPER. WITH BEAUTIFULLY ILLUMINATED SARLOW.

8vo, Oriental gold-stamped camelskin binding with flap, and red tooled doublures.

(XVIIIth Century:)

$£ 1515 s$

The famous Makamat of Al-Hariri have been translated by Messrs. Chenery and Steingass, in 1898 in the Oriental Translation Fund, New Series,

\section{BURMESE.}

SCENES FROM THE LIFE OF BUDDHA.

I28 A MAGNIFICENT BURMESE PICTURE BOOK, ON STOUT NATIVE PAPER, ILLUMINATED IN GOLD AND COLOURS, ON ONE LONG FOLDING PANORAMA, SO PAINTED AS TO FORM FOUR SEPARATE SCENES. (I 7 FEET by 20 INCHES).

Folio, red and green lacquered boards, with gold ornamentation.

(Burma. XVIIIth Century.)

(See Illustration, Plate No. LVII.).

A very interesting series of paintings, with running Burmese text in. Burmese native characters at the bottom. Most interesting for the. varieties of native lay and clerical costumes shown, details, of landscape, temples, animals, flowers, trees, mountains, priests and worshippers. 
Plate LVII.

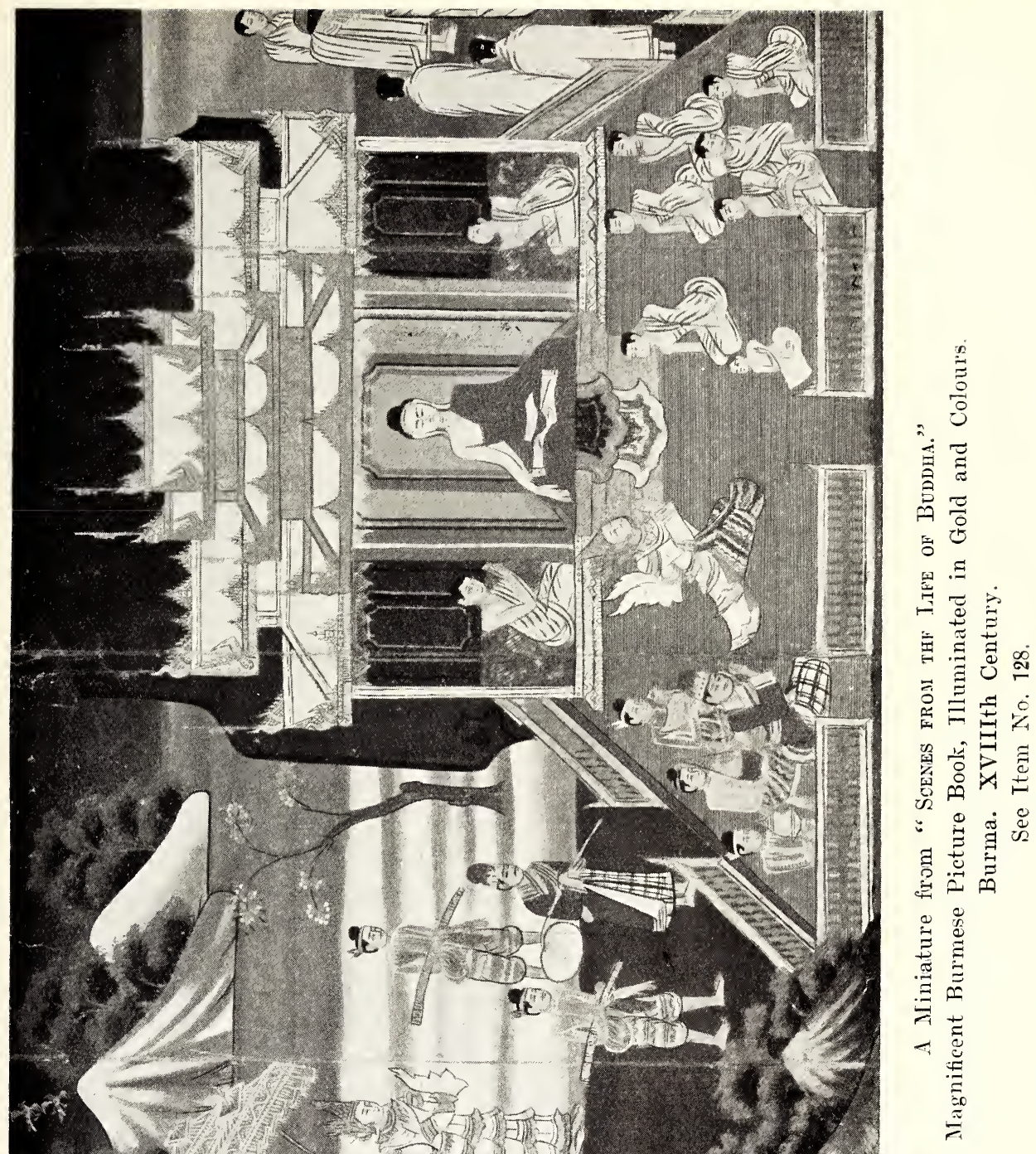


Plate LVIII.

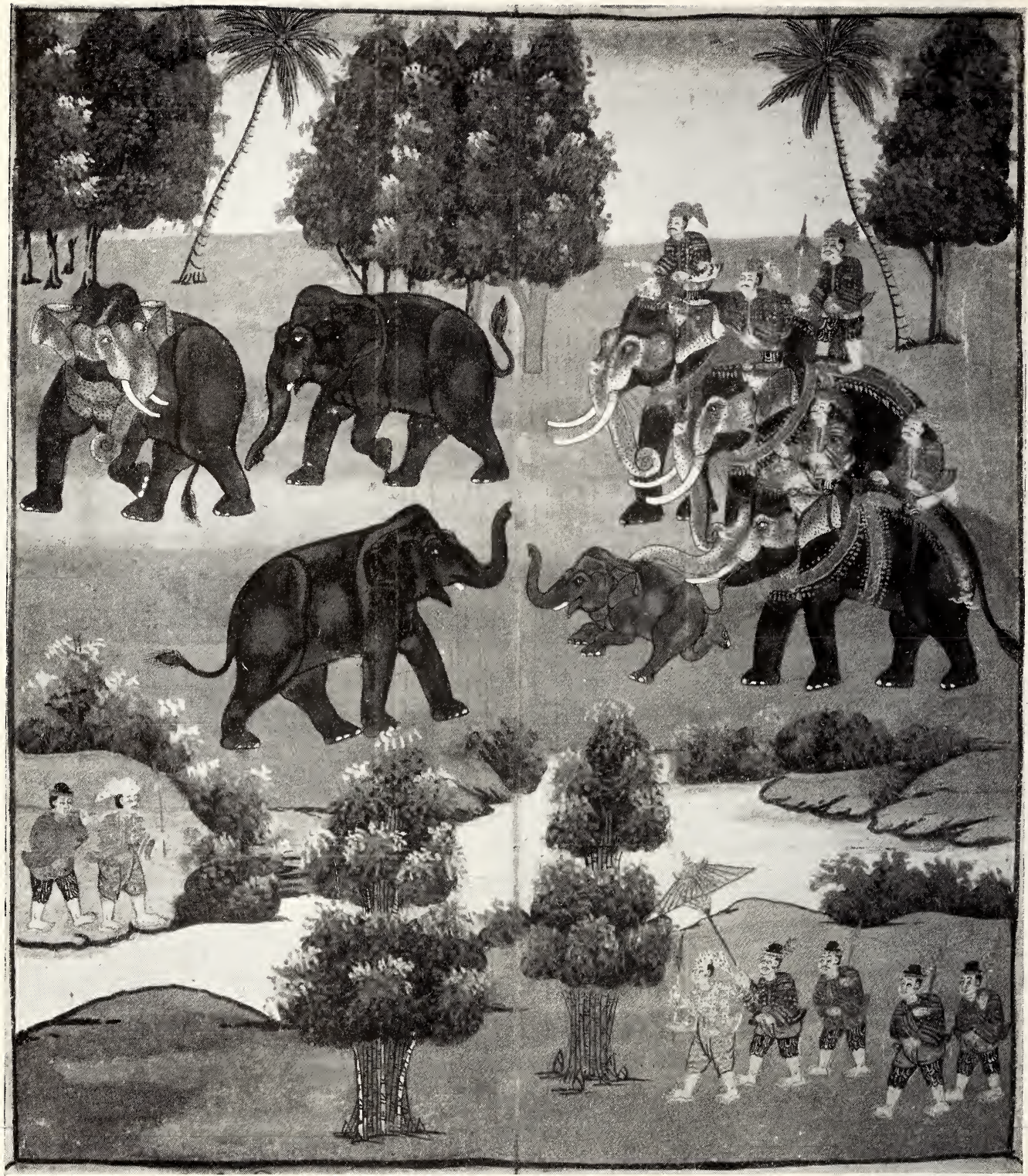

Two Minatures from "The Native Srorts of Burva."

Burmese Illuminated MS. Picture Book.

Burma. Early XVIIIth Century.

See Item No. 129 
MAGGS BROS., 34 \& 35, Conduit Street, London, W.

Burmese MSS,_continued.

The Native Sports of Burma.

I29 SPORTS AND FESTIVALS OF THE COURT OF BURMA.

BURMESE PICTURE BOOK ON STOUT NATIVE PAPER BEAUTIFULLY ILLUMINATED IN GOLD AND COLOURS IN ONE LONG FOLDING PANORAMA, SO PAINTED AS TO FORM NINE SEPARATE SCENES.

Folio, native binding.

(Burma. Early XVIIIth Century).

(See Illustration, Plate No. LVIII.).

$£ 30$

The scenes represent: Catching wild elephants by means of trained female decoy elephant, chained by the leg; Tiger Baiting from, Elephants; Horse-riding, Archery, Chariot Riding, Dancing, Polo, ete.

\section{HEBREW.}

\section{30 BOOK OF ESTHER.}

THE ORIGINAL HEBREW TEXT OF THE BIBLICAL BOOK OF ESTHER WRITTEN IN SQUARE HEBREW CHARACTERS ON A PARCHMENT SCROLL CONSISTING OF GOATSKINS SEWN TOGETHER. (MEASURING I I $\frac{1}{2}$ INCHES by 9 FEET.)

(XVIIIth Century.)

$£ 55 s$

The Book of Esther is annually read from a vellum scroll by observant Jews on the anniversary of the Feast of Purim, on the 14th day of the month Adar.

\section{PALI.}

\section{I3I BUDDHIST SCRIPTURES.}

A Commentary on Sarattha-dipani, Sariputta's commentary on Buddhaghosa's commentary, Samanta-pasadika on the Vinaya-pitaka, one of the Buddhist scriptures.

PALI MANUSCRIPT ON PALM-LEAVES.

Oblong folio, original native binding of gilt wooden boards.

(India. XVIIth Century.) 


\section{PERSIAN.}

\section{I.32 AMIR KHUSRAU.}

Khirad Nameh or Aina-i-Sikandari. The Mirror of Alexander the Great, a historical poem in Persian verse, a counterpart to Nizami's Iskandar-Nameh.

PERSIAN MANUSCRIPT. IN NEA'TLY WRITTEN NASTALIK IN 4 COLUMNS, I9 LINES TO A PAGE, AND WITH 6 BEAUTIFULLY ILLUMINATED MINIATURES IN GOLD AND COLOURS, AND 4 ILLUMINATED ANWANS.

8vo, Oriental binding of stamped leather.

(Persia. About A.D. I 500.)

$£ 5210$ s

The margins of the text have been repaired in a few cases touching the text; the miniatures are perfect.

\section{I.33 SALMAN SAWAJI.}

The Diwan, or poems of Salman Sawaji. (In Persian.)

PERSIAN MANUSCRIPT WRITTEN IN A NEAT AND LEGIBLE HAND IN DOUBLE COLUMNS, I 7 LINES TO A FULL PAGE, WITH MAGNIFICENT ANWAN AT THE COMMENCEMENT IN A DEEP BLUE AND GREEN, WITH THE TJTLE OF THE WORK IN WHITE SQUARE CHARACTERS.

WITH 8 CHARMING AND DELICATE MINIATURES IN THE FINEST POSSIBLE STATE OF PRESERVATION, MOSTLY OF GARDEN SCENES OR INTERIORS, BEARING TRACES OF MONGOL INFLUENCE.

8vo, Oriental binding of stamped leather.

(Persia. About A.D. I 530).

(See Illustration, Plate No. LiX.).

The Diwan is the best known work of Salman Sawajî, one of Persia's greatest poets. He died in 1377. 


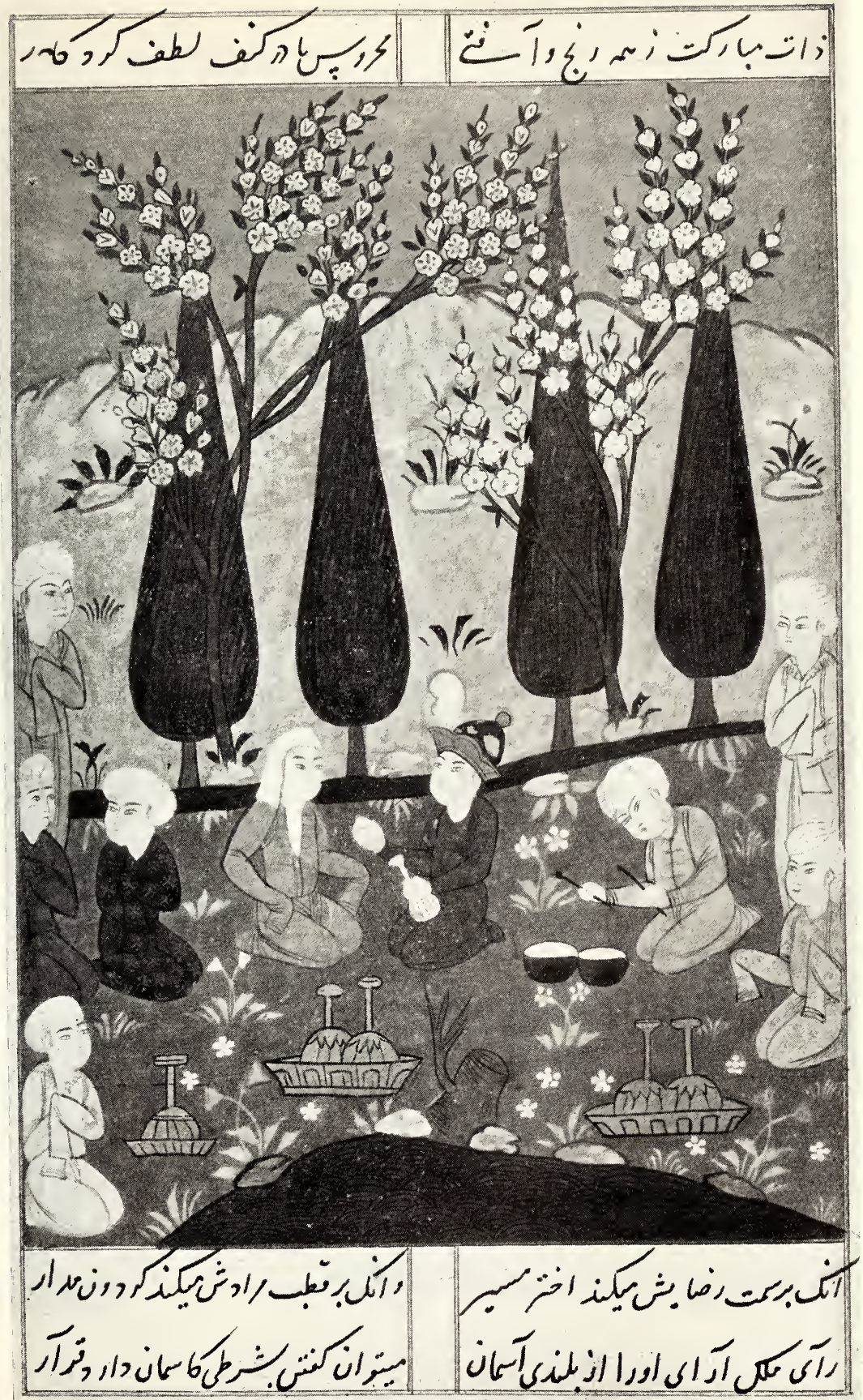

The Diwax or Pofms of Salmax Sawaji. Persian Illuminated Manuscript.

With 8 Miniatures by a Persian artist. About A.D. 1530. See Item No. 133. 


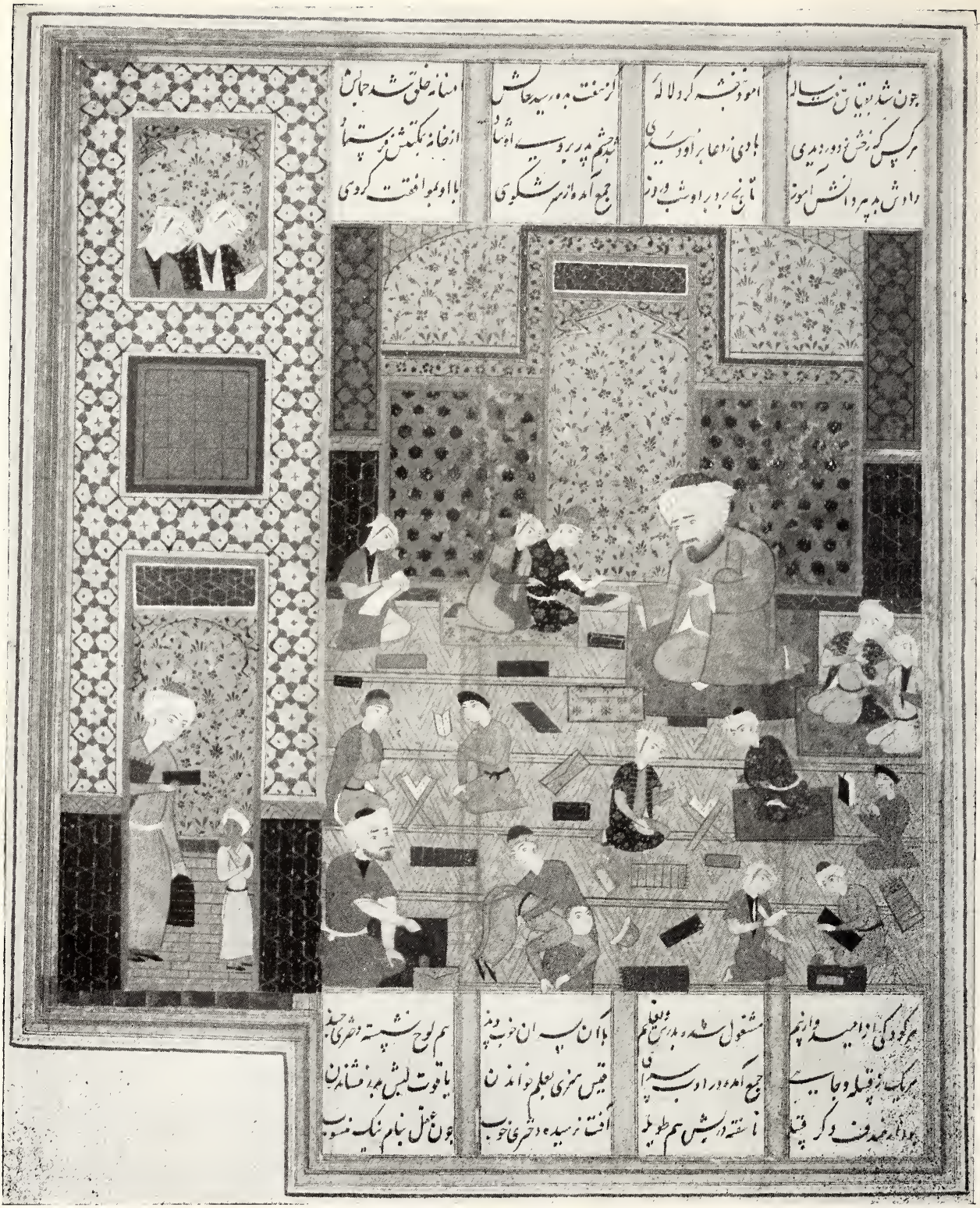

"A School Scene in Persia."

A Miniature (greatly reduced) from Jemal-Ed Din Nizami's " Khamsah." Persian MS. dated A.D. 1579.

With 34 large Miniatures. See Item No. 134. 


\section{Persian MSS.-continued.}

\section{I34 JEMAL-ED DIN NIZAMI.}

\section{The Khamsah or five Treasures.}

PERSIAN MANUSCRIPT CONTAINING THE MAGAZINE OF MYSTERIES (MORAL POEM), WITH TALES AND FABLES, THE LOVES OF CHOSROES AND THE BEAUTIFUL SHIRIN, 'THE LOVES OF LEILA AND MAJNUN, THE HAFT PAIGAR (THE SEVEN FIGURES), THE ROMANTIC HISTORIES OF THE KING BARAMGUR, AND THE SEVEN PRINCESSES, AND FINALLY THE ISKANDAR NAMAH (THE HISTORY OF ALEXANDER THE GREAT).

THE MANUSCRIPT IS WRITTEN IN FOUR COLUMNS AND CONTAINS 34 FULL-PAGE MINIATURES. IT IS DATED I 579 A.D.

Small folio, in the original Persian binding, most elaborately tooled. and gilt, beautifully gilt back, with leather doublure.

(Dated A.D. I 579.)

(See Illustration, Plate No. LX.).

FROM THE LIBRARY OF THE KING OF OUDH. THE WRITER AND ARTIST

WAS PAID 5,000 RUPEES AT THE TIME ACCORDING TO A MS. NOTE.

The miniatures are as follows:-

1. Dancing before the King.

2. A Banquet at Court.

3 and 4. Magnificent full page ornamentation in gold and colours.

5. Family Scene in the Desert. The baby is being fed.

6. The King giving audience.

7 and 8 . Full page ornamentation in gold and colours.

9. A Lion Fight.

10. The Banquet in the Harem.

11. Luncheon in the Harem.

12. Dancing in the Harem.

13. Music in the Harem.

14. At Home in the Harem.

15. A Scene in the Harem.

16. A Concert in the Harem.

17. Public execution, a man suspended by heels in the open, being stoned.

18. Chosroes on horseback, perceives the beautiful Shirin for the first time.

19. A Polo match to the accompaniment of a band.

20. A Visit in the Desert, mountain goats and gazelles in the distance.

21. A Scene in the Harem.

22 and 23. Illuminated Sarlows.

24. Picturesque scene at school, 15 boys in various stages of being taught and caned. The master is represented a giant in stature and intellect.

25. The King in a drunken frolic, falls off his couch. Amazement of the ladies of the Harem, some of whom bite off their thumbs in their astonishment.

26. The Golden Age, in which Gazelles, Tigers, Lions, Rabbits, Panthers, Donkeys, Boars, etc., live in peace and harmony.

27 and 28. Two illuminated Sarlows.

29. A Scene at Court.

30. A Fierce Fight and a King's Death.

31 and 32. Two illuminated Sariows.

33. Alexander's Pavilion in the Forest.

34. (Double page.) A great Banquet at Court. 
Persian MSS.-continued.

\section{I.34a MOHAMMAD ASSAR.}

Mihir ul-Mushtari.

A POEM IN PERSIAN VERSE, BEING THE ROMANCE OF THE. SONS OF THE KING AND THE VIZIER. BEAUTIFULLY WRITTEN MANUSCRIP'T IN PERSIAN BETWEEN RULES OF BLUE, GOLD AND RED, ORNAMENTAL HEADINGS TO THE CHAPTERS, ADORNED WITH FLOWERS.

Svo, magnificent contemporary XVIth Century Persian binding of golden iacquer, and open leather work. With two fune decorative open pages.

(Persia. XVIth Century).

$£ 25$

\section{I35 PERSIAN POEMS.}

Album of Poems by different authors. (In Persian.)

PERSIAN MANUSCRIPT EXQUISITELY WRITTEN IN FINE. NASTALIQ CHARACTERS ON VARIOUSLY DECORATED PAGES WITH VERY PRE'T'Y ILLUMINATIONS IN FANCIFUL DEVICES AT INTERVALS.

Small oblong, limp morocco binding.

(Late XVIth Century.) 
Persian MSS._continued.

\section{The Most famous Literary Monunient of Persia.}

\section{36 FIRDUSI.}

The Shah-Nameh (The Epic of Kings).

BEAUTIFULLY WRITTEN MANUSCRIPT IN PERSIAN, EACH PAGE DIVIDED INTO FOUR COLUMNS, SURROUNDED BY ONE GOLD LINE, DATED A.D. I622 AND WRITTEN (PROBABLY IN INDIA) AND ILLUMINATED BY MOHAMMED SAADIA IBN HAFIZ IBRAHIM.

WITH FULL-PAGE ORNAMENTATIONS (ANWANS AND SARLOWS) AND 6 LARGE MINIATURES, BEAUTIFULLY PAINTED IN GOLD AND COLOURS, IN EXCELLENT PRESERVATION.

Small folio, original leather binding, with mosaic inserted of grey leather in which flowers are tooled.

(Dated A.D. i662).

(See Illustration, Plate No. LXi.).

List of Mixiatures :-

1. Three men praying before a tomb, in background forest.

2. King surrounded by his attendants, seated on tiger siin. In front of him, wild animals.

3. The Demon overthrowing a man.

4. A King in his Palace, in front of him a native band.

5. A King surrounded by his court.

6. A Ruler in his Palace.

7. A Ruler on a Terrace, with attendants.

8. A Prince giving audience.

9. A Prince hunting.

10. A Prince murdering another Prince on a Terrace in the Country

11. Tartars killing a Persian on Horseback.

12. A Sword fight on Horseback.

13. 'The King of the 'Tartars giving audience to Persians.

14. Two men in the Country and the Simurg (fabulous dragon).

15. A King giving audience..

16. The Birth of Rustem.

17. Rustem beheads a man.

18. Seren men fighting with lances on horseback.

19. A consultation in the Talace.

20. A feat of Strength on Horseback.

21. The Prince's Education.

22. Rustem's Dream.

23. Rustem killing the Dragon.

24. Rustem capturing the Demon.

25. Rustem kibling the old man of the mountains.

26. Rustem knocks the chief of the Tartars out.

27. A King in an aerial chariot.

28. A fight in an open field.

29. A ride through fire.

30. The Lucky victor.

31. Rustem kills his enemy.

32. Rustem meets the Tartar chief on horseback. 


\section{Persian MSS - continued.}

\section{Firdusi-continued.}

33. Breakfast at Court.

34. Deeds of Prowess.

35. The 'Tartar chief is cleft in twain, his horse also.

36. Capture of the Enemy's helmet.

37. Rustem hits the Tartar chef in the eye with his arrow.

38. A Tartar meets his death at Rustem's hands.

39. The enemy riding on an elephant is vanquished by Rusteni.

40. Rustem succeeds again.

41. The Demon throws Rustem into the River.

42. Rustem saves a lady in the Well.

43. The Great Battle.

44. The foe is vanquished by Rustem.

45. Lassooing the enemy.

46. A Speedy Retreat.

47. The Persians Win again.

48. 'The Enemy has no luck.

49. Terrible defeat.

50. A Pleasant meeting.

51. The ruler at home.

52. A Reception.

53. Terrific Combat with a green dragon.

54. A Gallant Prince receives his visitors.

55. A Battle for 'Two.

56. The Aged King is brought a Prisoner before his Enemy.

57. The King hunting five gazelles and hitting each at the same time.

58. The King cleaves the Lion in two.

59. The King cutting the green Dragon's head off.

60. The King killing the black, grey-haired demon.

61. The King in his Car killing the Simurg.

62. A Pleasant Rest.

63. The Warriors in front of the City.

64. A Pleasant Lift.

65. Rustem putting the Enemy's eye out.

66. Eight ladies at home.

67. Rustem transfixes a tree and his enemy behind it.

68. A Quadruple Combat.

69. The End of a Tartar.

70. The Persian Court, in a Garden

71. A Pleasant Fight.

72. The Warrior and the Hermit.

73. An Afternoon at home.

74. Meeting a Stranger.

75. The King and his Prisoners.

76. The Council.

77. In the Garden.

78. Coffee in the Garden.

79. Chasing Antelopes.

80. 'The Warrior's Death.

81. Petitioning the King.

82. Supper at Court.

83. Giving Audience.

84. Dancing in the Harem.

85. The Traitor's Punishment, hung head downwards from a pole, in the sight of the Court. 


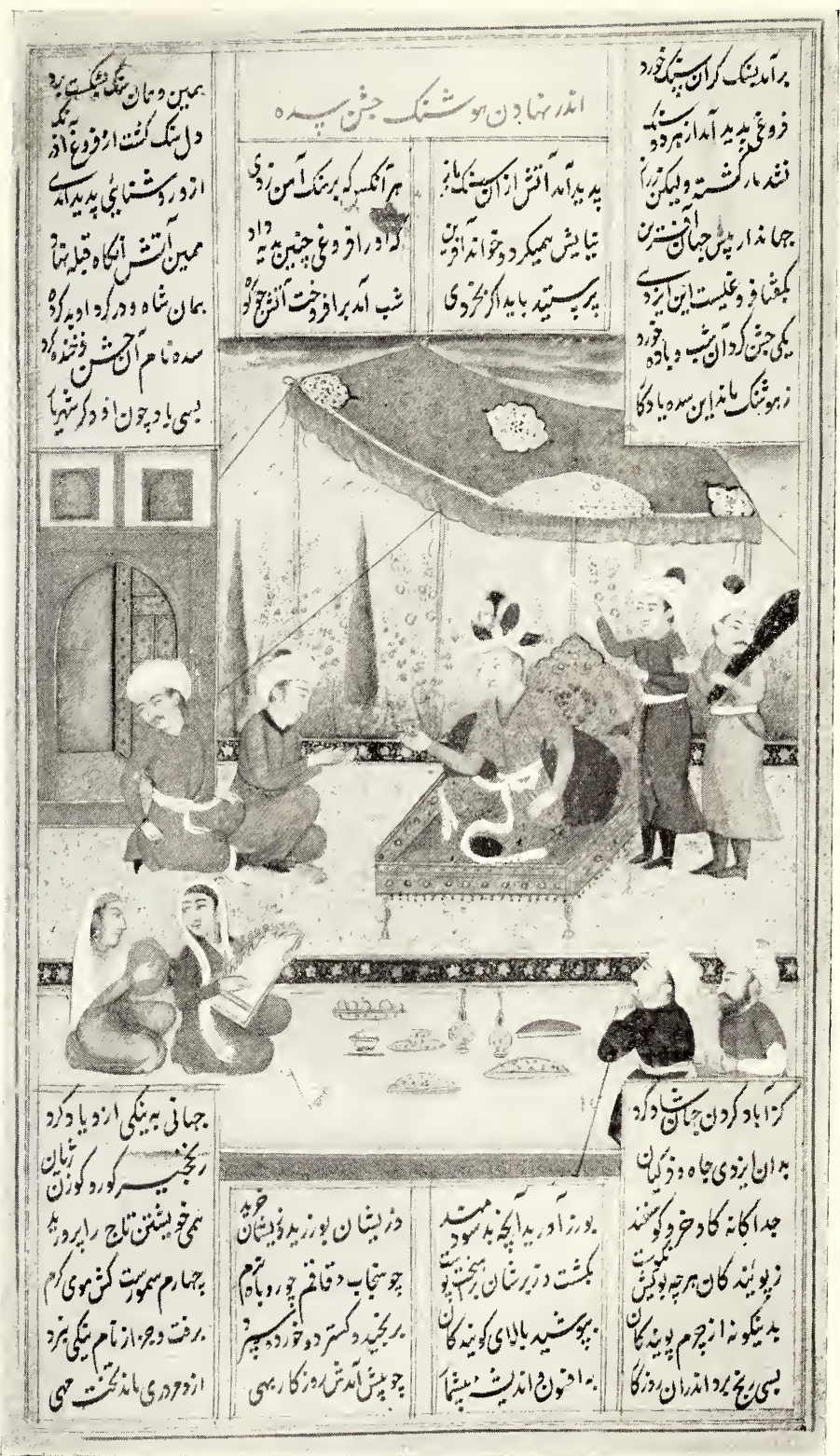

A Miniature from Firdesi's Shah-Naneh.

With 96 large Miniatures.

Persian Manuscript dated A.D. 1622.

See Item No. 136. 
Plate LXII.

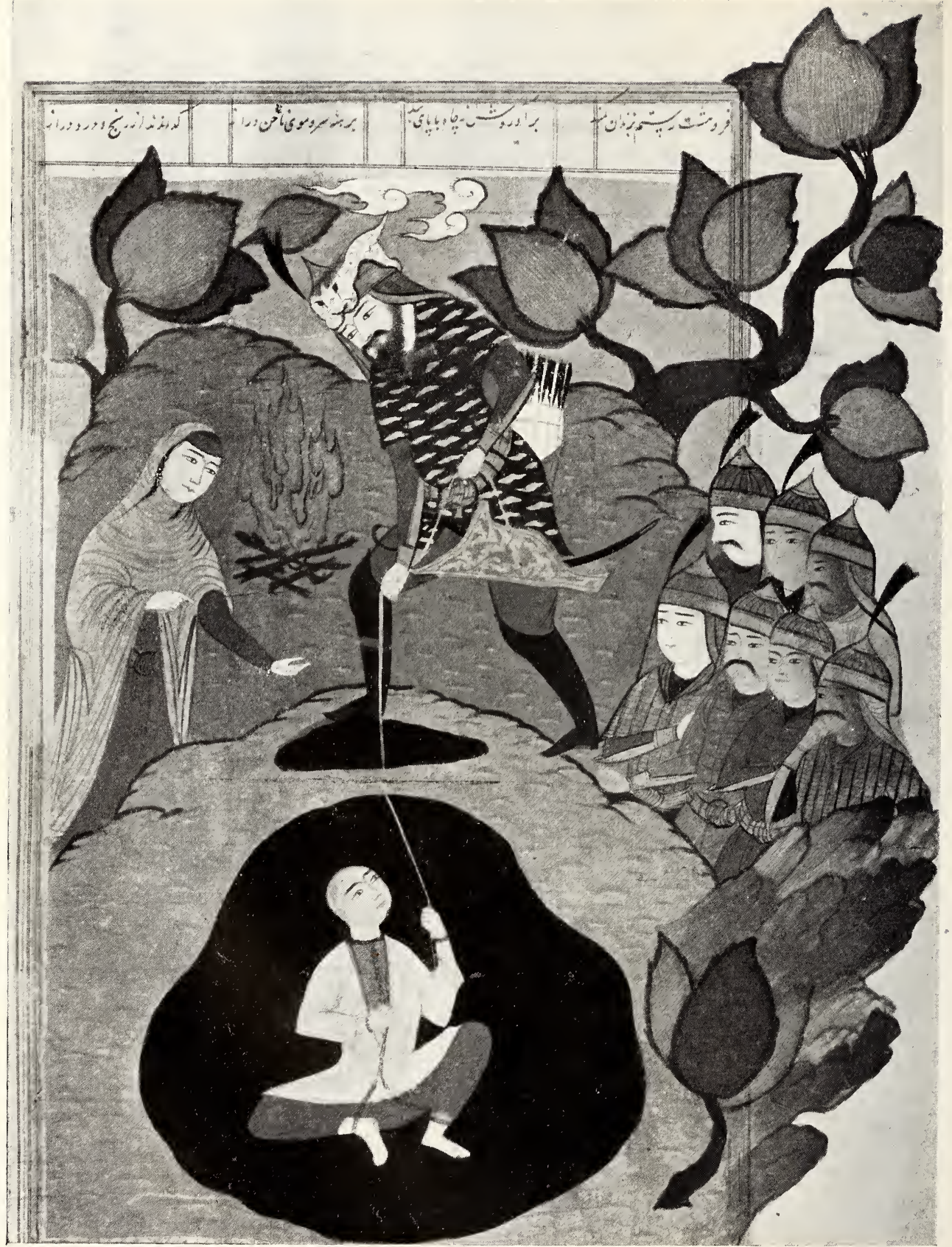

A Miniature (reduced) from Firousi's Shaн-Nameh (The Epic of Kings). Persian MS. on 340 pages of paper dated A.D. 1612. With 30 full-page Miniatures. See Item No. 137. 


\section{Persian MSS.-continued.}

\section{Firdusi-continued.}

86. The Persian Privy Council.

87. On the 'Terrace.

88. A fight in the Mountains, including Elepliants.

89. On the Ter race.

90. Single Combat on Horseback.

91. The Prince is killed.

92. The Knight to the Rescue.

93. Supper on the Terrace.

94. Death to the King.

95. I Council at home.

96. The 'Traitor's Death.

The Shah-Nameh, or Epic of Kings by the prince of Persian poets, FIRDUSI, is one of the great works of the world's literature. It comprises one hundred and twenty thousand rerses in Persian, and was finished by the author after thirty year's' work on the 23rd of February 985 A.D. at the age of seventy. It comprises the space of three thousand years and it is almost impossible to give a layman an idea of the vastness of the scale on which Firdusi worked. Mahmoud of Ghazna, the ruling monarch of the day, persuaded Firdusi to undertake this gigantic task by the promise of a piece of gold for each pair of verses.

After spending thirty years in composing this vast poem, which gives the finest idea of the national wars of the Tartars and Persians, Firdusi was rewarded by 60,000 pieces of silver instead of the promised gold pieces. The money was bronght to the poet at the moment that he was leaving the public baths. Piqued at the monarch's failure to keep his promise, Firdusi gave away his gift to the servants at the bath and the door-keepers.

The poet composed a particularly virulent satire on Mahmond, and gave it to the king's secretary, asking him to present it to him when he saw him plunged in one of his habitual fits of nelancholy. Immediately after handing the parce! of vitriolic verses, the poet disappeared and went to Bagdad, where he composed some verses in eulogy of the vizier of the khalif, being as well acquainted with the niceties of Arabic as of Persian. The vizier gave him an apartment in his palace and the Prince of the Faithful presented him with the 60,000 pieces of gold that had been promised him by Mahmoud. A threatening letter from Mahmoud arrived soon at Bagdad and forced the Thalif to ask Firdusi to leave his town in view of Mahmond's military renown.

On the point of leaving Bagdad, where his reception had been so hospitable, for Yemen. Firdusi heard that old friends had made his peace with Mahmoud. He returned to his native town, but a few days after his arrival, while walking with a child who recited verses from the SHAH NAMEH to him, the old man felt weak, and died after a few hours.

In 1020 A.D. while his cofin was heing carried out of the town, the humble procession was stcpped by a caravan of richly laden camels bringing sixty thousand pieces of gold from Mahmoud. The present was offered to his danghter who refused it with the words, "Firdusi's daughter does not need the presents of Kings." The money was then used to erect a magnificent tomb.

The Epic of Kings has been the favourite book for illustration by the Artists of lersia. The adventures of the invincible Persian hero Rustem, and his combats with men and spirits, are well depicted in the manuscript before us. 


\section{Persian MSS._continued.}

\section{I37 FIRDUSI.}

Shahnameh. (The Epic of Kings).

MANUSCRIPT OF THE MOST FAMOUS LITERARY MONUMENT OF PERSIA, WRITTEN IN PERSIAN, IN FOUR COLUMNS IN RED AND BLACK, ON 340 LEAVES OF PAPER, WITH 30 FULL-PAGE MINIATURES DEPICTING THE ADVENTURES OF THE HERO, RUSTEM. DATED A.D. г6ı2.

Small folio, original Persian binding of embossed leather.

(A.D. I6I2).

(See Illustration, Plate No. Lxil.).

$£ 3710$ s

\section{I3 JEMAL-ED DIN NIZAMI.}

The Khamsah. The five Romantic Poems. (In Persian).

6 parts in I volume.

PERSIAN MANUSCRIPT FINELY WRITTEN ON $9 I 4$ PAGES OF NATIVE PAPER, WITH ILLUMINATED ANWANS AND A SERIES OF 2I BEAUTIFULLY ILLUMINATED MINIATURES ILLUSTRATING THE STORIES, PAINTED BY AN ARTIST OF T'HE SCHOOL OF RIZA ABBASI, ONE OF THE MASTER PAINTERS OF PERSIA. WRITTEN BY ZAIN-UL-ABIDIN AL-YEZIDI AND DATED i623.

Royal 8vo, native binding (rebacked).

(Persia, A.D. I623.)

(See Illustration, Plate No. LXiit.). 


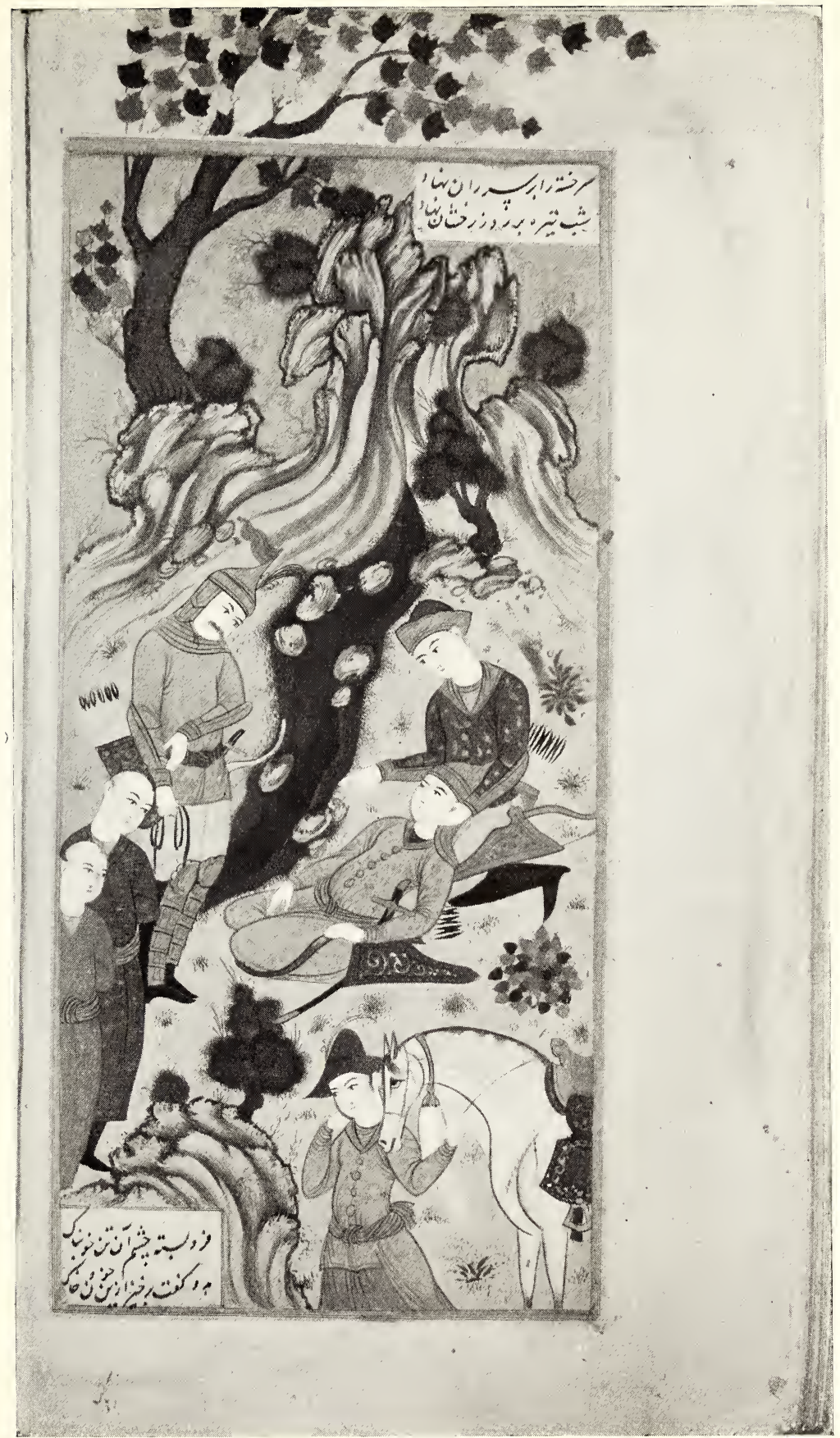

A Miniature from J bala-Ed DIx Nizami's Khamsah.

Persian Illuminated MS., with 27 Miniatures by an artist of the school of Rîza 'Abbâsi Transcribed by Zain-ul-Abidin al-Yezidi. A.D. 1623. See Item No. 138. 
Plate LXIV.

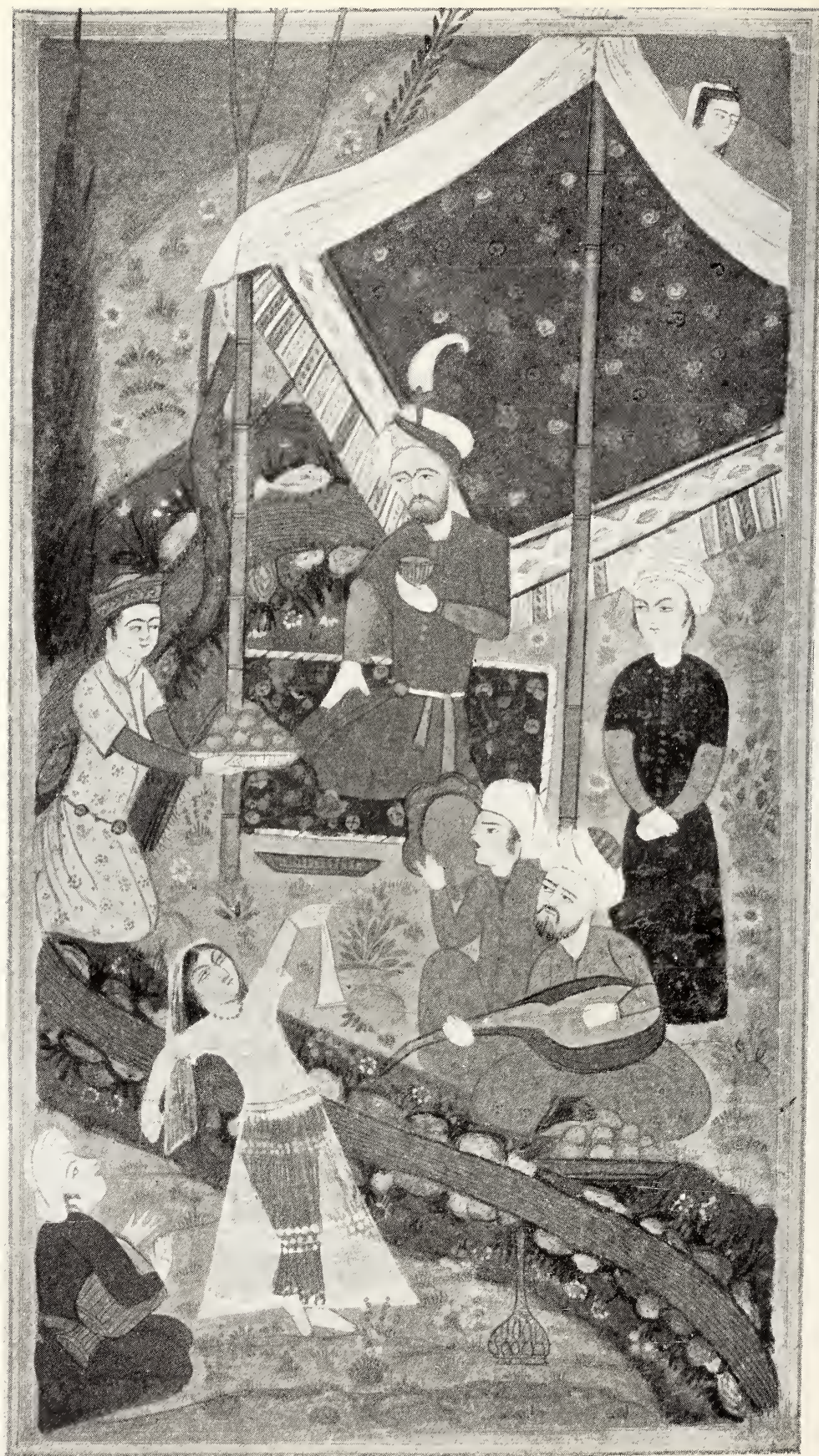

A Miniature (exact size) from the Diwan of Hafiz, " the Complete Lyrical Works." Persian MS., dated A.D. 1635.

With 8 Miniatures.

See Item No. 139. 


\section{Persian MSS.-continued.}

\section{I39 HAFIZ.}

\section{The Diwan or the "Complete Lyrical Works" in Persian.}

PERSIAN MANUSCRIPT BEAUTIFULLY WRITTEN IN A FINE NASTALIQ HAND IN DOUBLE COLUMNS WITHIN GOLD AND COLOURED RULES ON 396 PAGES OF PAPER. CHAPTER ORNAMENTS IN GOLD.

WITH ILLUMINATED SARLOW AND OPPOSITE PAGE. WITH EIGHT BEAUTIFULLY ILLUMINATED MINIATURES, EACH FILLING AT LEAST THREE-QUARTERS OF THE PAGE.

8vo, native red morocco binding with sunk lacquered floral panels.

(Dated A.D. I635.)

(See Illustration, Plate No. LXiV.).

$£ 35$

\section{40 SADI.}

\section{The Gulistan or "Rose-Garden." (In Persian.)}

BEAUTIFULLY WRITTEN PERSIAN MANUSCRIP'T, IN CALLIGRAPHIC NASTALIQ ON 303 PAGES WITHIN GOLD AND COLOURED RULES, ON PAPER OF VARIOUS COLOURS.

WITH GOLD AND COLOURED ORNAMENTS BEAUTIFULLY EXECUTED BETWEEN EACH OF THE LINES, 7 LINES TO THE PAGE, WITH FINELY ILLUMINATED ANWAN AND ONE FULLPAGE MINIATURE AT THE COMMENCEMENT OF THE MANUSCRIPT.

Folio, Orientai caif binding, with Oriental stamped centre of gold. arabesques and innner doublures of red leather, with artistically painted animal scenes, a lion eating a gazelle, a lion chasing a monkey up a tree, a representation of the fabulous phoenix; these scenes are painted in gilt on leather.

(Persia. XVIIIth Century.) 


\section{Persian MSS._continued.}

\section{I4I FIRDUSI.}

Shahnameh, or Epic of Kings. (In Persian.)

PERSIAN MANUSCRIPT BEAUTIFULLY WRITTEN IN I748 IN A FINE TALIK ON 534 LEAVES OF PAPER, WITH 83 FINELY ILLUMINATED MINIATURES AND FINE ILLUMINATED ANWANS (BOOK HEADINGS).

Small folio, original Oriental binding of leather.

(Dated A.D. I748.)

(See Illustration, Plate No. LyV.).

$£ 42$

I42 LIVES OF THE KINGS OF PERSIA. (In Persian verse.)

PERSIAN MANUSCRIPT WRITTEN ON ISO LEAVES OF PAPER (5 $5 \frac{3}{4}$ INCHES by $3 \frac{1}{t}$ INCHES), DOUBLE COLUMNS OF I 5 LINES.

THE TEXT BEAUTIFULLY AND CLEARLY WRITTEN WITHIN PLAIN GOLD BORDERS, WITH 64 FINELY PAINTED MINIATURES DEPICTING VARIOUS SCENES IN THE HISTORY OF THE SHAHS OF PERSIA, THE FIRST TWO PAGES FINELY DECORATED, HEADINGS IN RED ON GOLD BACKGROUND THROUGHOUT, MUCH TEXTUAL ORNAMENTATION.

Small 8vo, original Fersian lacquer binding in colours of a delightf ul design of roses and other flowers.

(Persia. Dated A.D. i 783.)

$£ 48$

\section{I43 COLLECTION OF PRAYERS.}

COLLECTION OF PRAYERS IN PERSIAN, BEAUTIFULLY WRITTEN ON NATIVE PAPER, WITHIN GOLD AND GREEN RULES, I6 LONG LINES TO A FULL PAGE. WITH CHARMINGLY ILLUMINATED ANWAN IN GOLD AND COLOURS, THE FIRST TWO OPENING PAGES HAVING IN ADDITION DAINTILY ILLUMINATED BORDERS IN BLUE, GOLD AND RED.

8vo, Persian lacquer binding with pretty designs in colours, of roses, narcissi, jonquills and other flowers. On the inside covers are narcissi.

(Persia. XVIIIth Century.) 
Plate LIV.

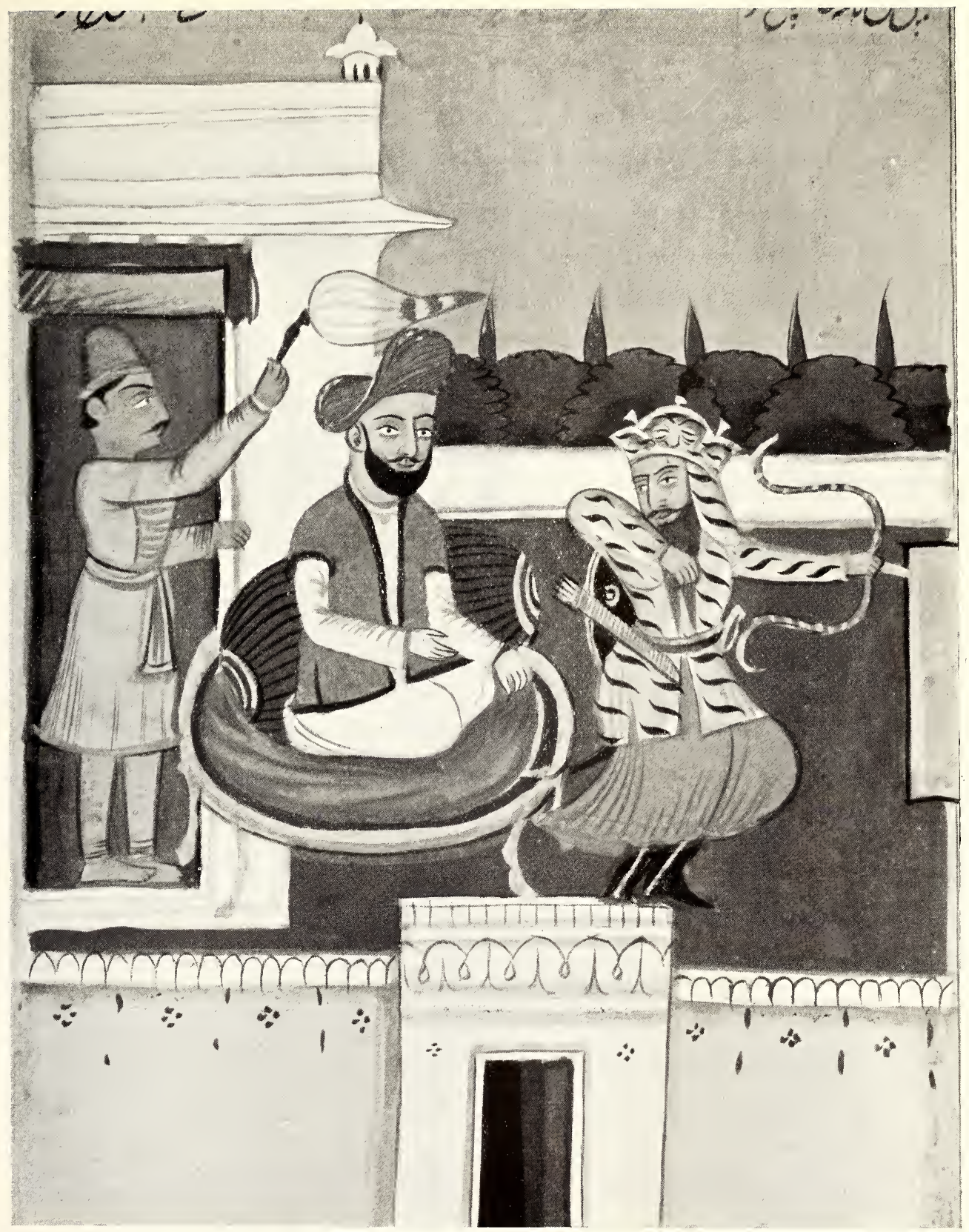

A Miniature from Firdusi's Shah-Nameh, or the Eipic of Kings (in Persian). Illuminated Persian MS. With 83 Miniatures. Dated. A.D. 1718.

See Item No. 141. 
I46 MAGGS BROS., 34 \& 35, Conduit Street, London, W.

Persian MSS,-continued.

I 44 MAARIJ AL-NUBUVVAT.

Farahi.

Introduction to the Life of Mahomet by Muin ben Haji Muhammad

PERSIAN MANUSCRIPT BEAUTIFULLY WRITTEN WITHIN RULED BORDERS, WITH TWO FINELY ILLUMINATED SARLOWS (EACH CONTAINING IN THE CENTRE A CHARMING MINIATURE DELICATELY EXECUTED IN GOLD AND COLOURS).

Folio, Oriental leather binding.

(Persia. XVIIIth Century.)

$£ 10$ 10s

\section{I45 FARID UL-DIN ATTAR.}

Mantik-ul-Tair. (In Persian.) A mystical allegorical poem.

PERSIAN MANUSCRIP'T WRITTEN ON 359 PAGES OF PAPER, DOUBLE COLUMNS, WITHOUT RULE.

Svo, beautifully stamped native leather binding with relief inscription the linings of old Indian printed cotton.

(A.D. I 844.)

$£ 1515 s$

\section{SAMARITAN.}

The Samaritan Pentateuch.

i 46 Pentate UCh. Manuscript of the Samaritan Pentateuch (Cenesis, Exodus, Leviticus, Numbers, Deuteronomy).

SAMARITAN MANUSCRIPT OF EXCESSIVE RARITY, WRITTEN ON SYRIAN WHITE PAPER, IN BLACK, IN THE ORIGINAL ANCIENT SAMARITAN CHARACTERS.

Small folio, original Samaritan binding of leather with flap.

XIXth Century.

* * This Manuscript was bought to London from the Samaritan High Priest in 1913. The Samaritans, who to the number of 450 , lived at Nablus, the site of ancient Samaria, are said to have been nearly exterminated by the Turks during the late war in Palestine. 
MAGGS BROS., 34 \& 35, Conduit Street, London, W.

\section{SANSKRIT.}

\section{47 BHAVAGAD-GITA.}

The Song of the Divine One. (Krishna.)

SANSKRIT MANUSCRIPT WRITTEN ON 858 PAGES OF NATIVE PAPER WITHIN GOLD AND COLOURED RULES. MANY PAGES ILLUMINATED. WITH 4.7 FULL-PAGE INDIAN MINIATURES WITH FLORAL BORDERS.

Small 4to, binding in Indian fabric, with outer flap.

(India. XVIIIth Century.)

This is the text book of the Puranic wership of Krishna (the Divine One) as Vishnu.

"Of the eclectic movement combining Sankhya, Yoga, and Vedanta doctrines, the oldest literary representative is the Cretaçatara Upanishad. More famous is the Bhagaradgita, in which the Supreme Being incarnate as Krishna expounds to Arjuna his doctrines in this sense. The burden of his teaching is that the zealous performance of his duty is a man's most important task, to whatever caste he may Delong. The beauty and the power of the language in which this doctrine is inculcated, is unsurpassed in any other work of Indian literature." (P'rofessor A. A. Macdonell's "Sanskrit Literature.")

\section{48 BHAVAGAD-GITA.}

\section{The Song of the Divine One. (Krishna.)}

SANSKRIT MANUSCRIPT WRITTEN ON 854 PAGES OF PAPER, WITHOU'1 RULES WITH I FULL-PAGE INDIAN MINIA'TURES CAREFULLY ILLUMINATED IN GOLD AND COLOURS.

Small oblong 4to, Indian morocco binding zeith fiap.

(India. NVIIIth Century.)

$£ 1515 s$

\section{SIAMESE.}

\section{49 PHRA MALAI.}

SIAMESE MANUSCRIPT BEAUTIFULLY WRIT'TEN IN NATIVE SIAMESE CHARACTERS ON NATIVE PAPER CONTAINING EXTRAORDINARY PICTURES OF SIAMESE WORSHIPPERS, EXECU'TED IN MANY COLOURS WITH VARIOUS BACKGROUNDS.

SOME DELIGHTFUL PIC'TURES OF SIAMESE STATUES OF THE BUDDHA IN COL.OURS HEIGHTENED WITH GOLD ADD TO THE INTEREST OF THIS UNUSUAL MANUSCRIPT.

THE BUDDHA IS SHOWN IN VARIOUS FORMS; ONE ESPECIALLY INTERESTING SCENE SHOWS US A ZEALOUS AND PIOUS NATIVE WORSHIPPER WHO HAS NOTHING ELSE TO OFFER PICKING RED LOTUS IN A POND. IN A SECOND MINIATURE WE ARE SHOWN HIM IN ADORATION BEFORE A MANIFESTATION OF BUDDHA PRESENTING HIS HUMBLE OFFERING.

O'THER MINIATURES SHOW US A PAGODA CONTAINING RELICS OF BUDDHA, etc., etc.

Long oblong folio, native binding.

(Siam. XVIIIth Century.) 


\section{Siamese MSS,-continued.}

Siamese Magical Mandscript with Miniatures in Colours.

\section{5 O PHROM MAXA.}

\section{Generations of Spirits.}

SIAMESE MANUSCRIPT WRITTEN ON NATIVE PAPER WITH NUMEROUS FINELY ILLUMINATED MINIATURES IN COLOURS.

Small oblong folio. (In lettered buckram case.)

(Siam. About i 700.)

(See Illustration, Plate No. LXVi.).

Together with a MS. translation into French with notes $\mathrm{ky} J$. Baptiste, Bishop of Nallos, who translated the work in 1847 for the Portuguese Consul at Siam.

The MS. was chiefly intended for divination purposes and was consulted in order to know what were lucky days for marriage, divorce, gambling, trading, sowing, etc. Part of the book is deroted to telling the future of a man according to his fate:-

"he will be faithful in love";

" he will be a mandarin";

"he will have sons";

" he will have a daughter",

"he will! be rich";

"he will be a prophet";

"he will be a slave";

"he will be not poor";
" he will be rictorious";

" he will have several wives who will lie in turn",

" he will commit suicicle";

" he will talk incessant nonsense";

" he will have slaves";

" he will have much money." Etc.

\section{TURKISH.}

\section{I ASTROLOGY.}

Treatise on Astrology, (In Turkisĥ).

BEAUTIFULLY WRITTEN MANUSCRIFT IN BLACK INK, WITII SOME WORDS IN RED AND BROWN, AND NUMEROUS COLOURED DRAWINGS (RED AND BLACK) OF AN ASTROLOGICAL CHARACTER. ON I 89 LEAVES OF PAPER.

I2mo, original Turkish leather binding with flap.

(XVIIIth Century.)

$£ 1212 s$

This little book contains some of the chief passages from the Koram which are used as charms, some Arabic prayers with a Turkish commentary on the origin and magical power, magic figures chiefly shown as seals of rarious prophets which may be used as amulets, and all kinds of formulas and litanies to which special magical powers are attached. 


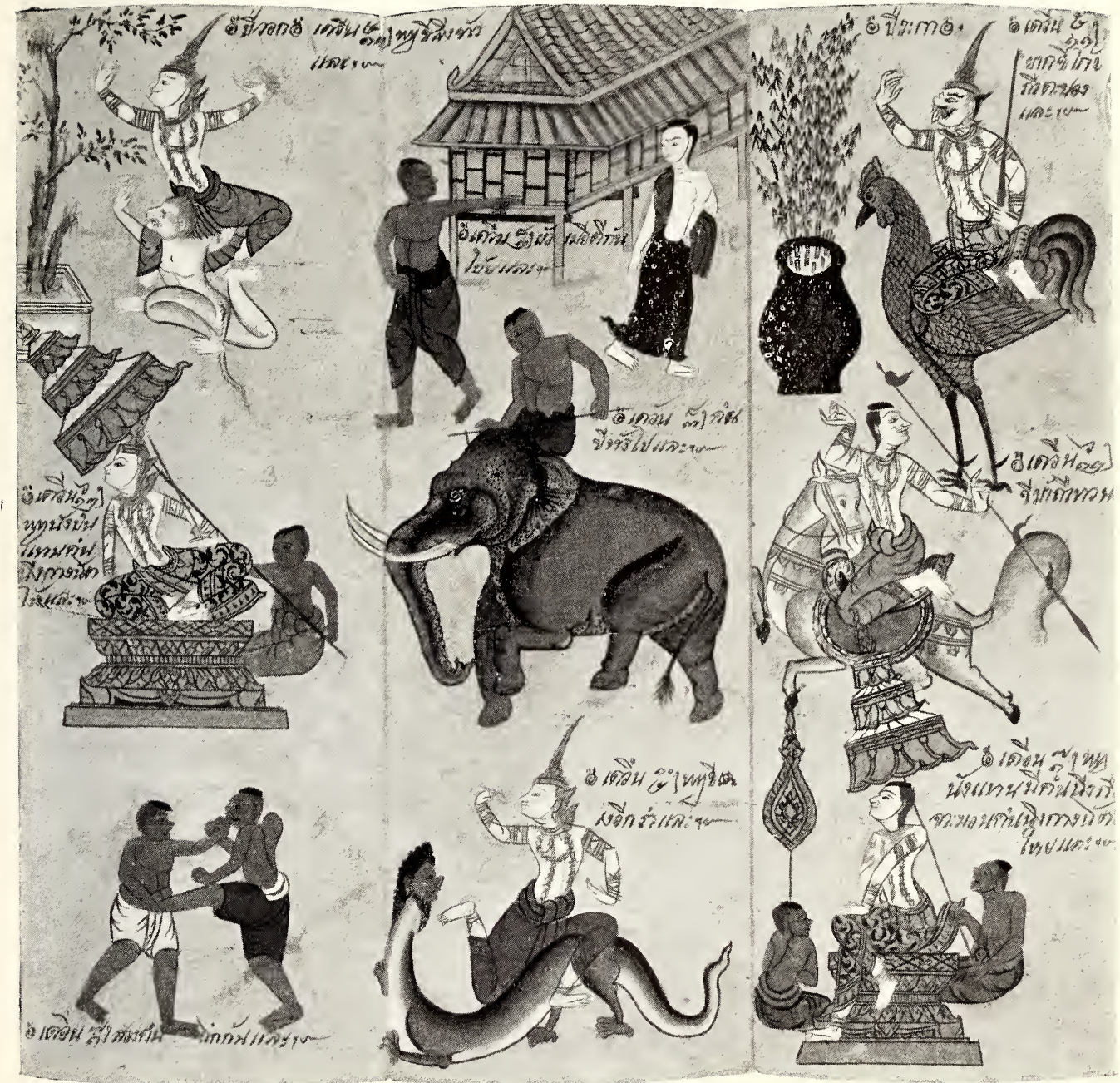

Three Miniatures from "Phrom Maxa." Jlluminated Siamese Magical MS. With Miniatures in Colours.

Siam, about 1700 .

See Item No. 150 . 
Plate LXVII.

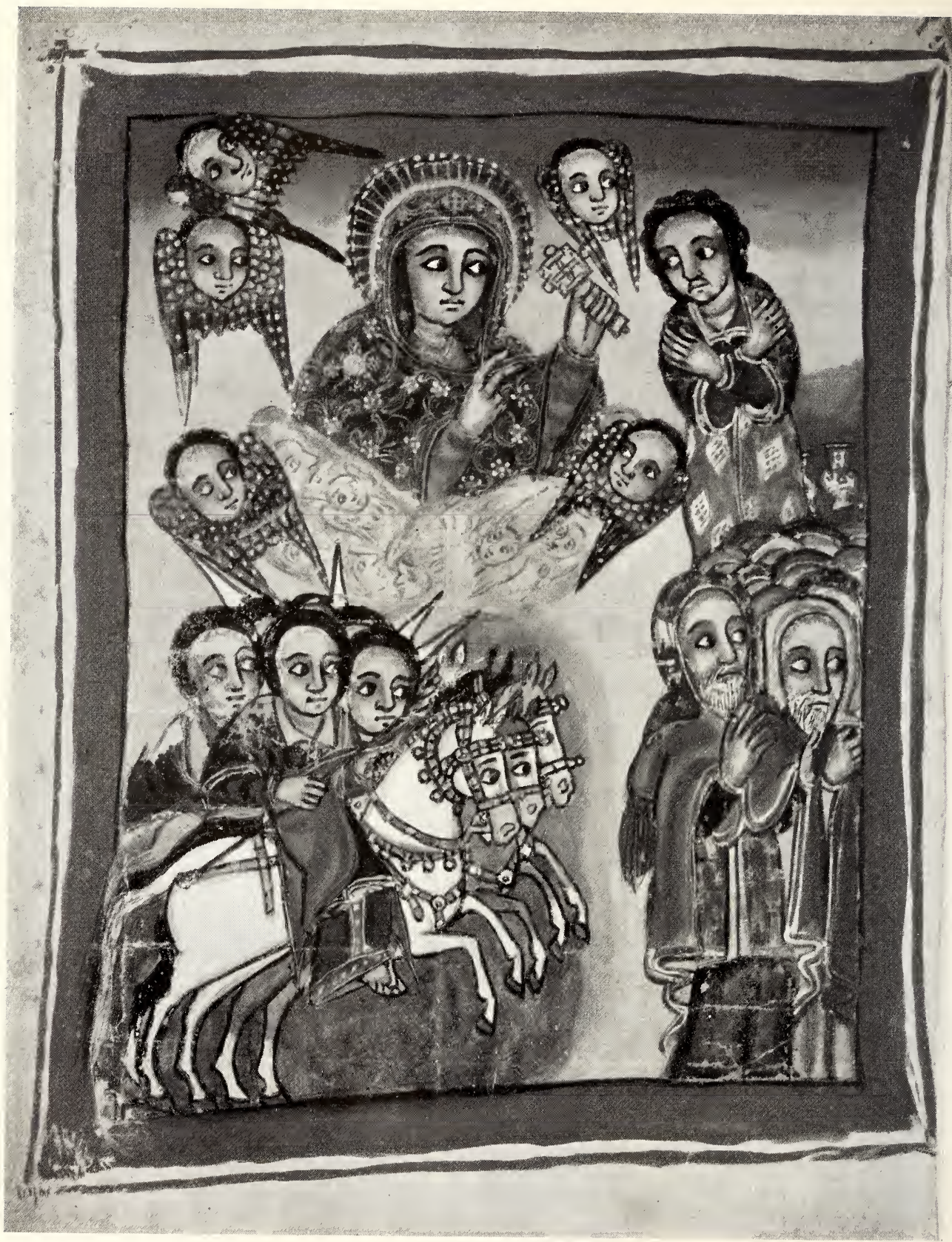

Abyssinian Paintixg on Vellum.

Abyssinia. XVIIIth Century.

see Item No. 152. 


\section{PART IV.}

\section{Illuminated Miniatures from Oriental MSS.}

\section{ABYSSINIA.}

\section{I52 ABYSSINIAN PAINTINGS ON VELLUM.}

THREE SCENES FROM THE BIBLE PAINTED IN A MOST INTERESTING BYZANTINE MANNER ON BO'TH SIDES OF A LEAF OF VELLUM. THE COLOURS ARE MOS'T IN'TERES'TING.

(MEASURING 9 by $6 \frac{1}{2}$ INCHES.)

(Abyssinia, XVIIIth Century.)

(See Illustration, Plate No. LXVII.).

\section{ARABIC.}

I 5.3 FRAGMENTS OF THE KORAN WRITTEN IN MINUTE KUFIC CHARACTERS IN ARABIC, ON VELLUM, WRIT'TEN IN THE XIIth CEN'TURY OR EARLIER.

(MEASURING $2 \frac{3}{t}$ by $I \frac{1}{2}$ INCFiES.)

THE TWO FRAGMEN'TS ARE SET IN MODERN ILLUMINATED BORDERS AND FRAME. THE MANUSCRIP'T CON'TAINS SURA'T AL-FAJAR (THAT IS CHAP'TER 89, VERSES I-I8), AND SURAT-ALANDIYA [(THAT IS CHAPTER 2I, VERSES 73, TWO LAST WORDS), TO 8I (FIRS'T FOUR WORDS).]

(XIIth Century.)

$£ 21$

\section{54 KORAN.}

FRAGMENT OF A KORAN, I6 LINES TO A FULL PAGE, ON VELLUM. WRIT'TEN IN KUFIC CHARACTERS IN BLACK AND RED WITH RED NOTATION. TWO LEAVES (A FEW PORTIONS MISS. ING), WRITTEN ON BO'TH SIDES, EACH Io by I 2 INCHES). WITHIN GLASS FRAME.

(Arabia, VIIIth Century.) 


\section{CHINESE.}

\section{I55 CHINESE DRAWING ON SILK.}

A CHINESE PHILOSOPHER SMELLING A FLOWER PRECEDED BY TWO BOYS BEARING A BASKET OF FLOWERS.

(MEASURING I 2 by I9 INCHES.)

(XVIIIth Century.)

$£ 210$ s

I56 CHINESE DRAWING ON SILK.

MOONLIGHT SCENE ON THE RIVER.

(MEASURING I2 by 19 INCHES.)

(XVIIIth Century.)

$£ 210$ s

\section{HERAT.}

\section{PORTRAIT OF BUDDHA.}

DELICATE PEN DRAWING DEALING WITH AN INCIDENT IN THE LIFE OF PRINCE SIDDHARTHA, THE PRINCE SEATED LISTENING TO MUSIC, A LITTLE DOG BY HIS. SIDE, HE IS HOLDING A BOOK IN HIS HAND, AT THE BACK IS A VIEW OF THE PALACE AND OF A LARGE TREE ON WHICH TWO BIRDS ARE PERCHED. DELICATELY DRAWN IN BLACK AND GREY, WITH GIL'T BORDERS AND GILT FLORAL DESIGN ON THE MARGINS.

HERAT SCHOOL WITH EUROPEAN INFLUENCE.

(MEASURING $7 \frac{1}{2}$ by 4 INCHES.)

(Herat. XVIIth Century.)

(See Illustrution, Plate No. LxViII.).

£31 10s

I 58 A LADY WITH A LAMP. STANDING IN A DELIGHTFUL LANDSCAPE WITH GAZELLES, ETC. DRAWING OF THE HERAT SCHOOL WITH EUROPEAN INFLUENCE.

(MEASURING 8 by 4 INCHES.)

(Herat. XVIIth Century.)

$£ 1010 \mathrm{~s}$

\section{I59 VIRGIN AND CHILD.}

PERSIAN MINIATURE TASTEFULLY DRAWN IN GOLD AND COLOURS. HERAT SCHOOL WITH EUROPEAN INFLUENCE.

(MEASURING 4 by $3 \frac{1}{2}$ INCHES.)

(Herat. XVIIth Century.) 
Plate LXVIII.

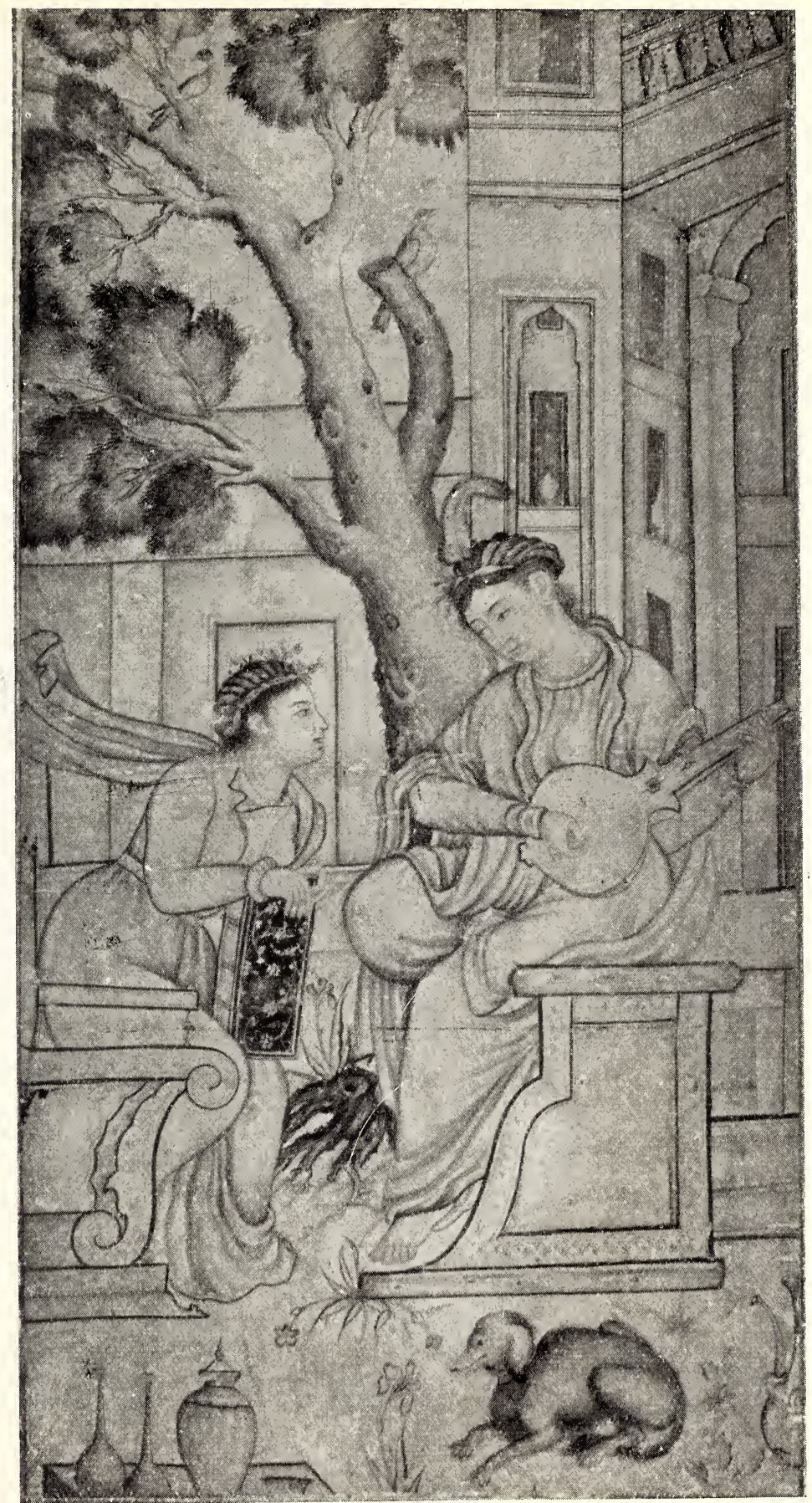

Portrait of Budnea.

Pen drawing.

Herat School with European Influence.

Herat. XVIIth Century.

See Item No. 157. 


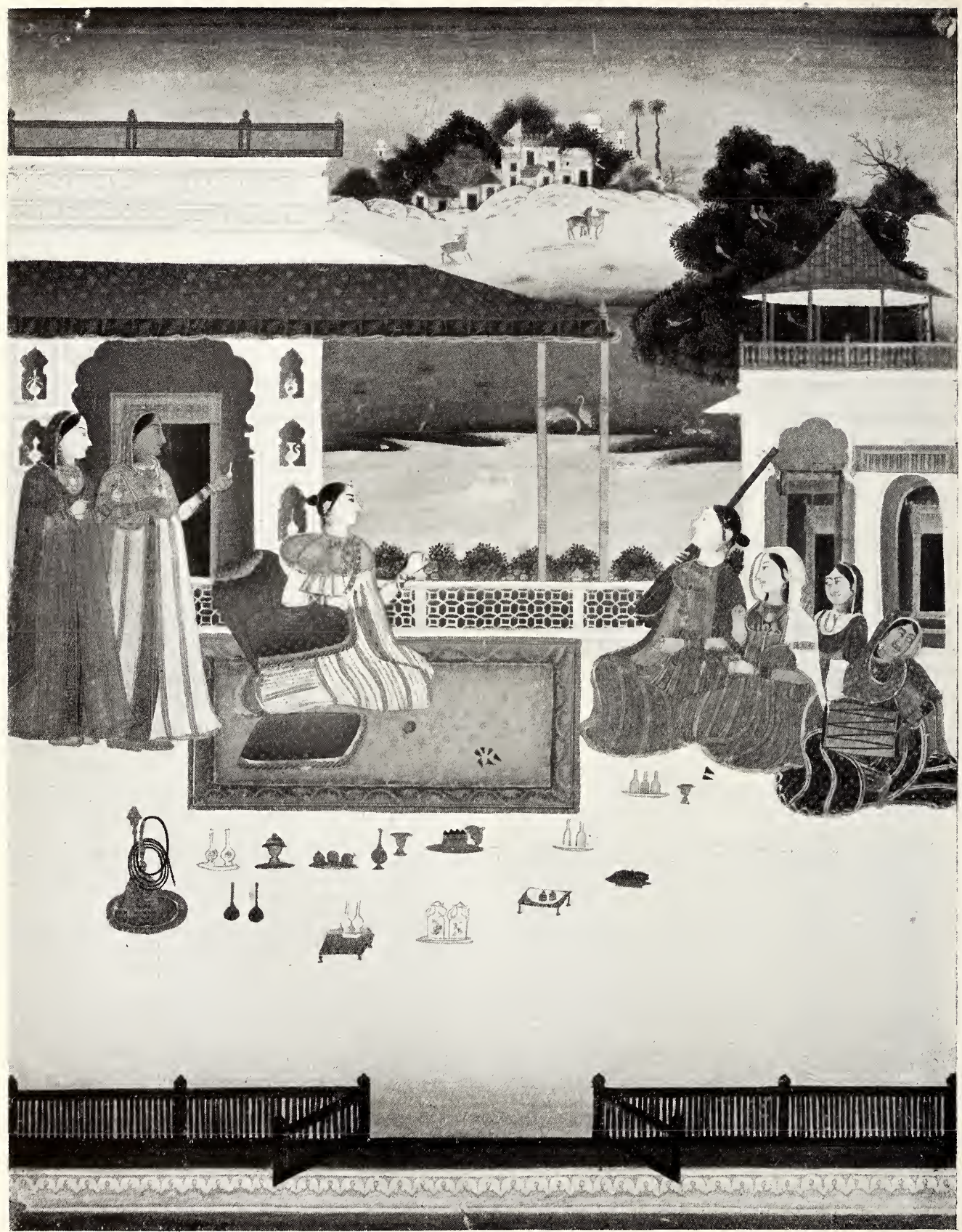

A LADY being Entertained outside a House Delhi School.

India. XVIIth Century. See Item No. 163. 


\section{INDIAN (School Unknown).}

I6o AN INDIAN HUNTING SCENE.

A HUNTING CHEETAH CHAINED ON A 'TWO-WHEELED CAR'T' DRAWN BY AN'TELOPES BEING DRIVEN TO THE HUN'IING-FIELI) BY TWO SEPOYS.

INDIAN DRAWING IN COLOURS FULL OF OBSERVATITON OF NATURE.

(MEASURING $4 \frac{1}{8}$ by $5 \frac{3}{4}$ INCHES.)

(India. XVIIIth Century.)

$£ 8$ s

\section{I6I ELEPHANT FIGHT.}

WATER-COLOUR DRAWING OF AN ELEPHANT FIGHT; THEY ARE BEING URGED ON BY FIREWORKS BEING LET OFF UNDER THEIR 'TRUNKS, AND WATER BEING SQUIR'TED ON THEM. O'THER MEN ARE STANDING BY WI'TH LANCES AND POLOSTICKS.

(MEASURING io by i6 INCHES.)

(India. XIXth Century.)

$£ 88 \mathrm{~s}$

I62 INDIAN MINIATURE IN OUTLINE SKETCH. A MAN BOWING TO THE GROUND BEFORE A HOLY MAN SEATED ON A MAT BESIDE A TREE.

(MEASURING $6 \frac{1}{\frac{1}{t}}$ by io INCHES.)

(India. XIXth Century.)

$18 s$

\section{INDIAN (Delhi Schcol).}

I6.3 A LADY BEING ENTER'TAINED OUTSIDE A HOUSE BESIDE A LAKE, WHERE ARE WATER-FOWL, IN THE DISTANCE A HILL WITH DEER, AND ON TOP THE MINARETS AND DOMES OF BUILDINGS.

Delhi School.

(MEASURING $12 \frac{1}{8}$ by $9 \frac{3}{8}$ INCHES.)

(India. XVIIth Century.)

(See Illustration, Plate No. LXIX.). 
Indian (Delhi School)-continued

\section{I64 LISTENING TO SUPPLICATIONS.}

A SCENE AT NIGHT ON A MADRISA (TERRACE). A PRINCE BEING LED TOWARDS HIS COUCH UNDER A MOON AND STARRY SKY BY TWO LADIES WHOSE ARMS ARE AROUND HIM, WHILE A SERVAN'T HOLDS A CANDLE, AND ANOTHER STANDS BY WITH A MUSICAL INSTRUMENT (TAMBURA-VINA).

Delhi School.

(MEASURING $9 \frac{3}{4}$ by $6 \frac{3}{4}$ INCHES.)

(India. XVIIth Century.)

$£ 1515 s$

I65 A HINDU LADY SEATED BESIDE HER BED, ON THE MADRISA (TERRACE), OUTSIDE A PALACE PREPARING FOR REPOSE, TWO MUSICIANS BEFORE HER, AND A COMPANY OF SIX FEMALE ATTENDANTS WITH REFRESHMENTS, ETC., ALL ATTIRED IN GAY COSTUMES, BEAUTIFULLY ILLUMINATED AND HEIGHTENED WITH GOLD. ON BACK A FINE SPECIMEN OF CALLIGRAPHY.

Delhi School.

(MEASURING IO $\frac{3}{4}$ by $7 \frac{1}{8}$ INCHES.)

(India. XVIIIth Century.)

(See Illustration, Plate No. LXX.).

$£ 1818 s$ 


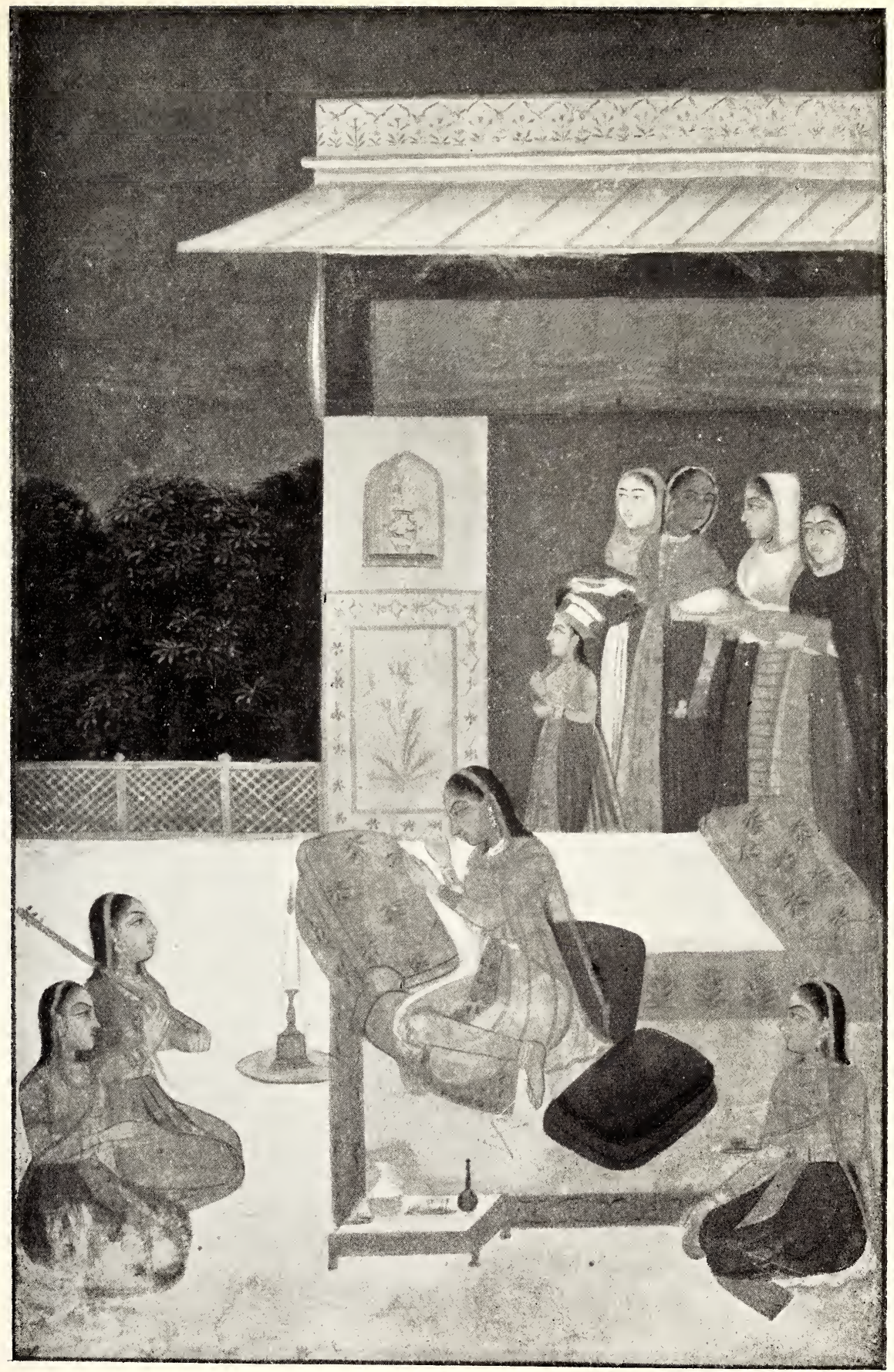

A Hindu Lady preparing for repose.

Delhi Schюol.

India. XVIIIth Century.

See Item No. 165. 


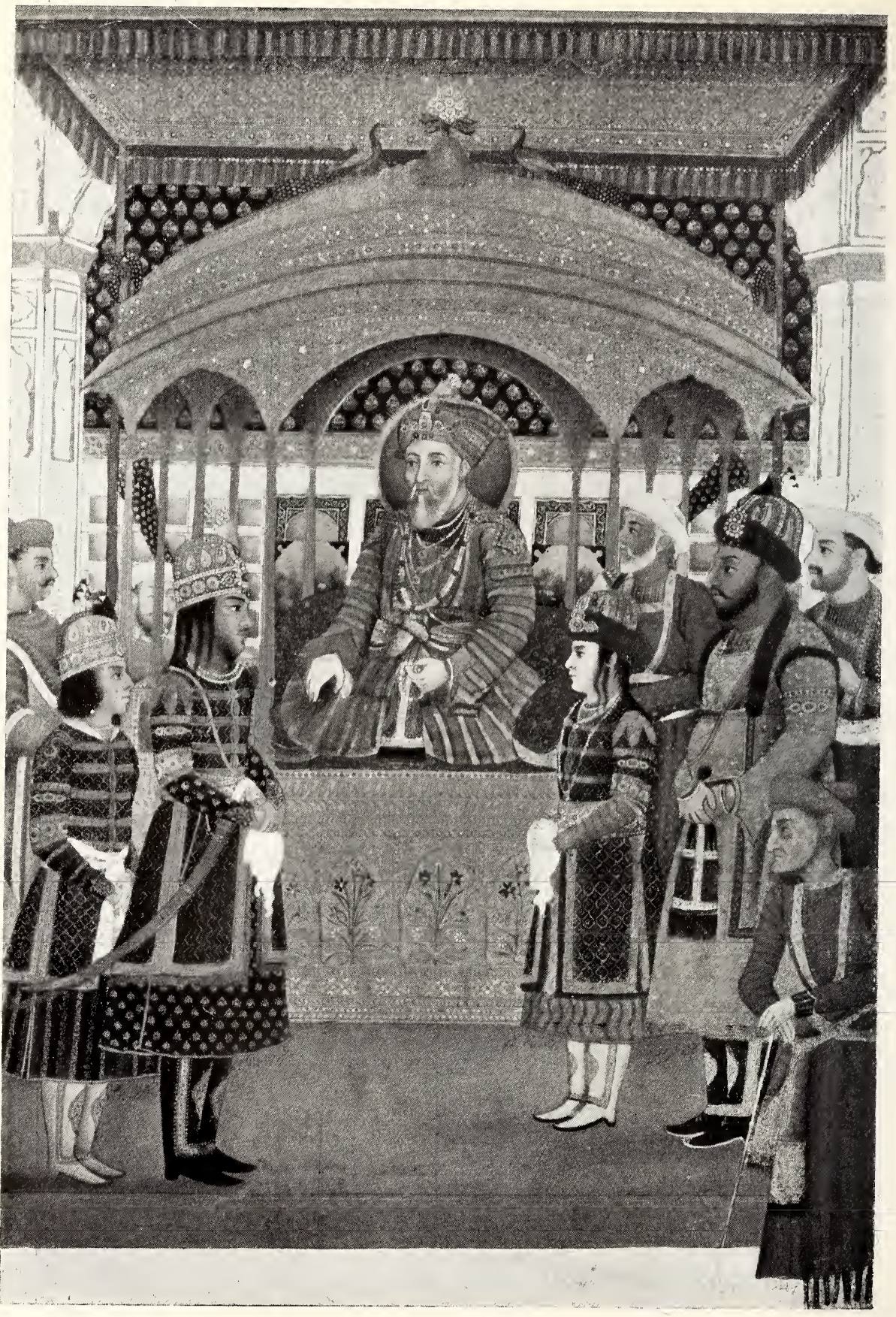

Portrait of BaAadur, late Emperor of Jelhi, with his sons. Delhi School.

Delhi. About A.D. 1820.

See Item No. $166^{\circ}$ 
Indian (Delhi School)-continued.

I66 PORTRAIT OF BAHADUR, LAST EMPEROR OF DELHI, SEATED ON HIS FAMOUS PEACOCK THRONE CLAD IN GOLDEN GARMENTS COVERED WITH PEARLS AND OTHER JEWELS. ON EITHER SIDE OF HIM STAND HIS SONS, WHOSE NAMES ARE GIVEN BELOW; MIRZA ABU SAFAR WALIHCDA, SHAH ZADAH MIRZA SELIM, MIRZA JAHANGIR BAHADUR, MIRZA BABUR, OTHER COURT OFFICIALS ARE STANDING AROUND WHOSE NAMES ARE ALSO GIVEN. THE THRONE IS SITUATED BENEATH A CANOPY OF CLOTH OF GOLD. THE MINIATURE IS A REMARKABLE EXAMPLE OF THE DELHI SCHOOL.

(Delhi. About I820.)

(MEASURING $7 \frac{1}{2}$ by 5 INCHES.)

(See Illustration, Plate No. LXXi.).

$£ 85$ 


\section{INDIAN (Indo-Persian or Moghul School).}

Magnificent Decorative Portrait of the Emperor Aurangzib on his StATE ElEphant.

I68 THE EMPEROR AURANGZIB IN A COSTUME OF WHITE EMBROIDERED WITH FLOWERS SEATED ON HIS STATE ELEPHANT, ADORNED WITH GOLD EMBROIDERED SADDLE-CLOTH, WITH A MAHOUT IN FRONT, IN A LANDSCAPE. WITH AN ANIMATED AND FLORAL BORDER IN WATER-GOLD, ON DARK BLUE BETWEEN TWO NARROW BORDERS.

Moghul School.

(MEASURING I $3 \frac{1}{2}$ by $10 \frac{1}{4}$ INCHES.)

(India. XVIIth Century.)

(See Illustration, Plate No. LXXII.).

$£ 45$

I6g THE NATIVITY AND ADORATION OF THE MAGI.

MINIATURE WITH EUROPEAN INFLUENCE. WITH DELICATE COLOURS.

Moghul School.

(MEASURING 7 by 5 INCHES.)

(India. XVIIth Century.)

$£ 88 s$

I 70 PORTRAIT OF AN INDIAN RULER.

MINIATURE, CAREFULLY DRAWN WITH ANIMATED MARGINS OF BLUE SHOWING DEER, BIRDS, BEARS, MONKEYS, TREES, FLOWERS, ETC.

Moghul School.

(MEASURING $6 \frac{3}{4}$ by $3 \frac{1}{2}$ INCHES.)

(India. XVIIth Century.)

$£ 335$

\section{i I P PORTRAit OF A PRINCE.}

MINIATURE SHOWING A PRINCE WITH VERY DARK COMPLEXION, A FINE TURBAN ON HIS HEAD, ADMIRING TWO ROSES IN HIS HAND. HE BEARS A SWORD, SHIELD, AND DOUBLEHANDLED DAGGER.

Moghul School.

(MEASURING $8 \frac{1}{4}$ by 5 INCHES.)

(India. XVIIth Century.) 


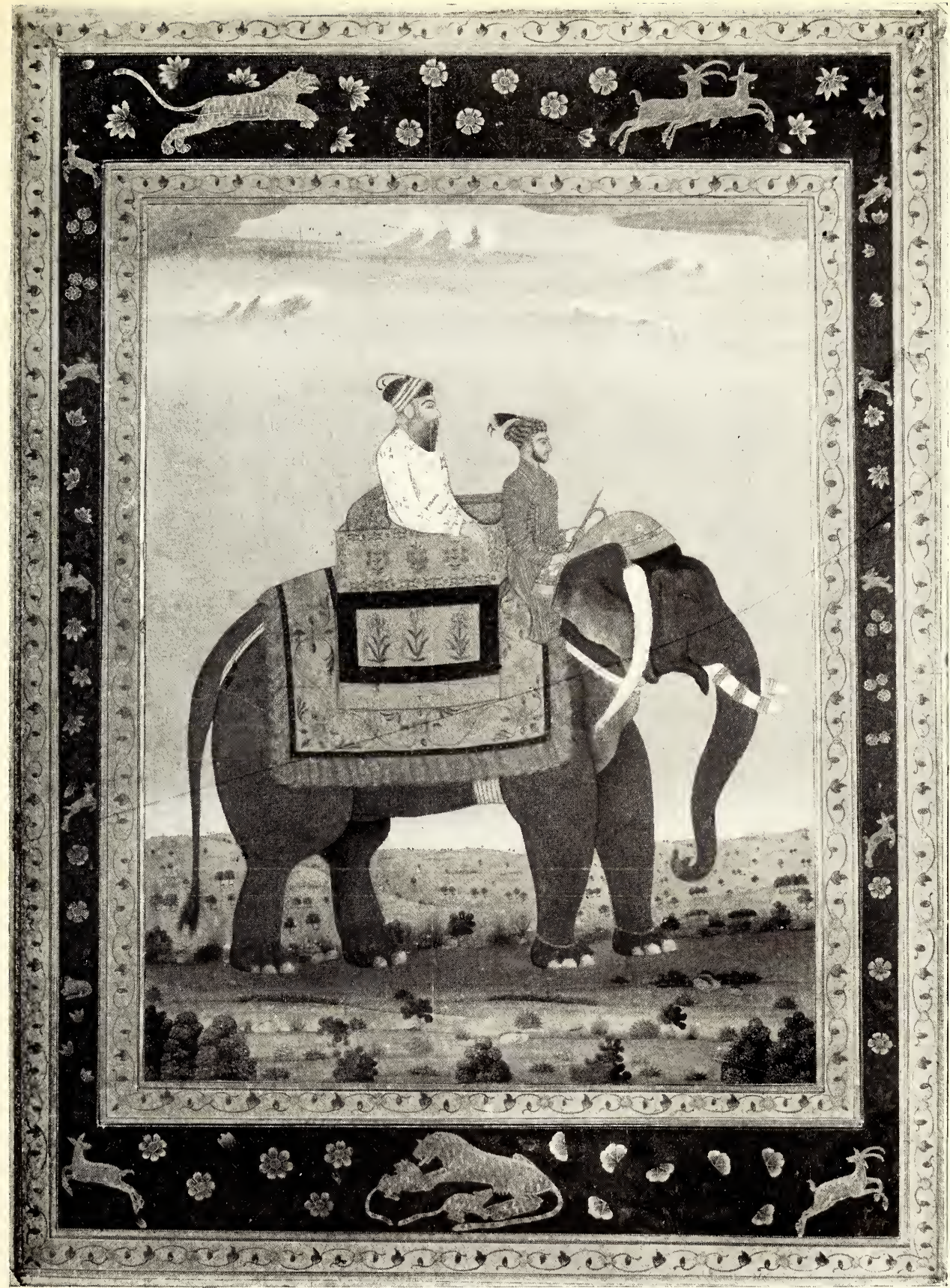

"The Emperor Aurangzib on his state Elephant." Magnificent decorative poutrait. Moghul School.

India. XVIIth Century. See Item No. 168. 


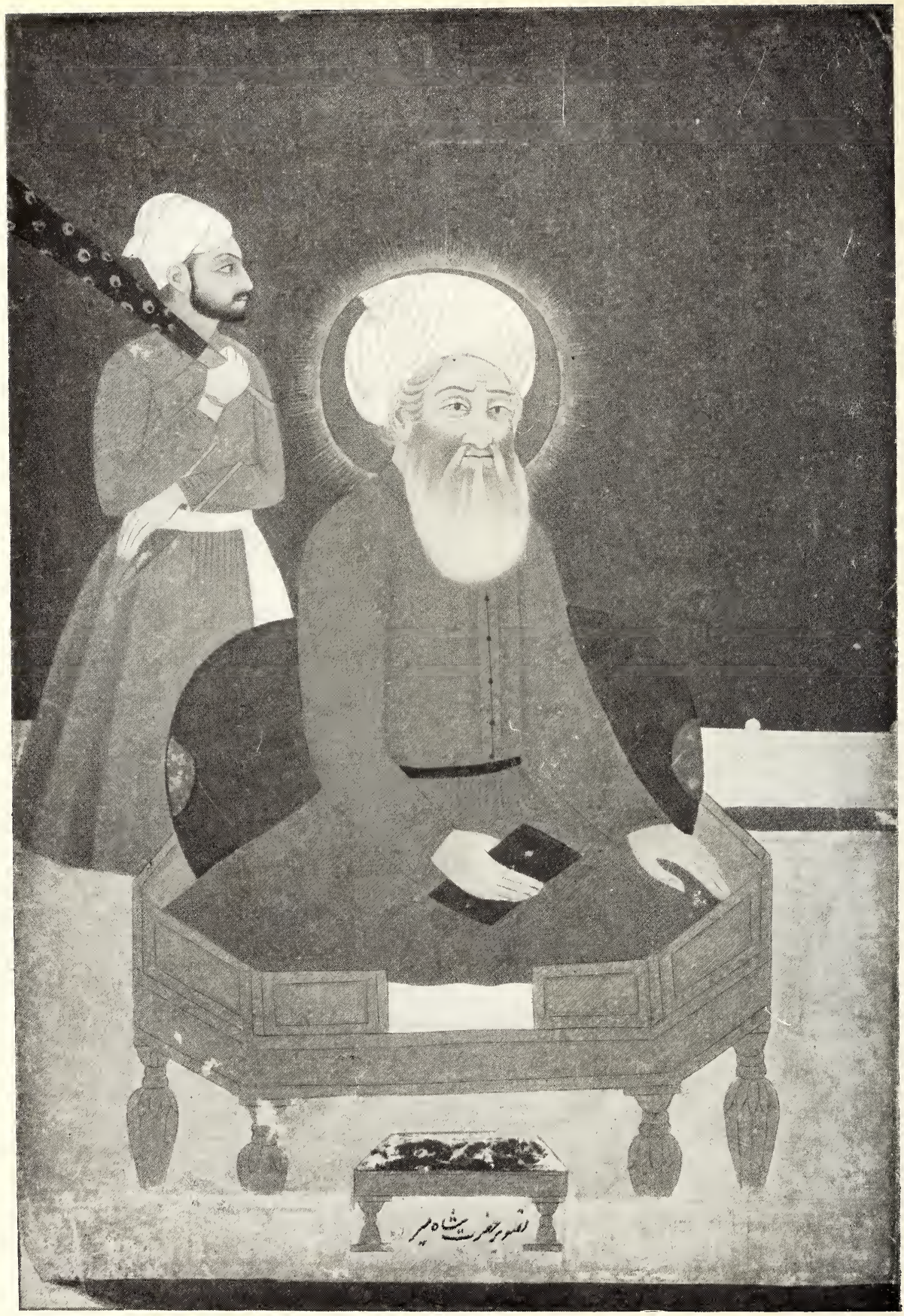

Portrait of Sinnix.

Moghul School.

See Item No. 172. 
Indian (Indo-Persian or Moghul School)-continued.

I 72 VERY FINE PORTRAIT OF SHAMIN, A FAMOUS INDIAN RULER AND HOLY MAN. A MURCHAL BEARER BEHIND HIM. A BEAU'TIFUL. POR'TRAIT OF THE GREY-BEARDED INDIAN. A VERY DECORATIVE AND LARGE MINIATURE.

Moghul School.

(MEASURING i I by $8 \frac{1}{2}$ INCHES.)

(India. XVIIth Century.)

(See Illustration, Plate No. LXXiII.).

$£ 42$

I7.3 A SHAH SEATED ON A TERRACE OF HIS PALACE, WITH A PAVILION IN THE BACKGROUND; IN THE FOREGROUND A GARDEN AND FOUN'TAIN, THE SHAH IS WEARING WONDERFUL PEARLS AND HOLDS A FLOWER, BEFORE HIM AN ATTENDAN'T.

Moghul School.

(MEASURING 9 by 6 INCHES.)

(India. XVIIth Century.)

$£ 1010$ s

I 74 SHAH JEHAN VISITING A HOLY MAN; A WELL-KNOWN SCENE OFTEN REPRESENTED; SHAH JEHAN, RICHLY DRESSED, IS SEATED BEFORE THE HOLY MAN, IN FRONT OF A SMALL HOUSE WITH A YELLOW ROOF.

VERY FINE MINIATURE.

Moghul School.

(MEASURING $7 \frac{1}{2}$ by 5 INCHES.)

(India. XVIIIth Century.)

$£ 1010 s$

I 75 INDIAN TEACHER SURROUNDED BY SEVEN DISCIPLES SEATED ON TERRACE. FINE CLOUD EFFEC'T IN DISTANCE. CALLIGRAPHY ON BACK.

Moghul School.

(MEASURING 9 by $6 \frac{3}{4}$ INCHES.)

(India. Late XVIIIth Century.)

$£ 1010$ s 


\section{PREFATORY NOTE.}

\section{Rajput Painting.}

"Rajput painting is the Hindu painting of Rajputana and the Panjab Himalayas. Its period may be taken as from about the beginning of the XIIIth Century A.D.-when the Raiputs, dispossessed of capital cities such as Delhi, where classic Indian art and literature was still preserved, began to adjust their iife to changed political conditions - to the middle of the XIXth Century. The term Rajput is employed because all the works discussed have been produced under the patronage of Rajput Princes; it conveniently summarises the fact of broad distinction from Moghul; and is preferable to any sectarian name such as Hindu, because that would have too wide a geographical application. Raiput painting is the counterfart of the vernacular literature of Hindustan. A vigorous archaic outline is the basis of its language. Uncompromising as the golden rule of art and life desired by Blake, sensitive, reticent, and tender, it perfectly reflects the self-control and sweet serenity of Indian society. It lends itself to the utterance of serene passion and the expression of unmixed emotions. But such an outline is not only Indian; it leads.us back not merely straight to Ajanta, but in its affinities, it is paralleled in Egypt, in pre-Hellenic and Mykenean drazing, and in Assyrian sculpture. This Raiput art is in effect the last phase of a now longlost style, a style that rises up before us, and awakens in us, as Okakura suggests, an ineffaceable regret. It is an art nearly related to that wonderful school of folk-drama-the yatras of Bengal and rasas of Upper India-that without scenery, without the artistic display of costumes, could arouse emotions which nowadays we scarcely experience." (From Coomaraswamy's Monograph on Rajput Painting). 


\section{INDIAN (Rajput School).}

I 77 A NOBLE INDIAN LADY WHOSE GOLDEN TROUSERS ARE VISIBLE THROUGH HER DIAPHANOUS ROBES, SE'T'TING OU'T FOR A MOONLIGHT WALK FROM HER ZENANA, WITH THREE LADY AT'TENDANTS MOST ELEGANTLY DRESSED IN SIMILAR SUMMER ATTIRE, WITH A MAN ATTENDANT DRESSED IN WHITE, BEARING A THREE-WICK LAMP, LEADING A SMALL CHILD BY A LEALING-STRING.

Rajput School.

(MEASURING I 2 by 8 INCHES).

(India. XVIIth Century.)

$£ 1212 s$

I 78 A LADY SITTING ON A TIGER SKIN IN THE MIDDLE OF A BEAUTIFUL LANDSCAPE, IRIS AND ANEMONES GROWING AROUND HER. Raiput School. (MEASURING $7 \frac{1}{2}$ by $5 \frac{1}{2}$ INCHES.) (India. XVIIth Century.)

$£ 610 \mathrm{~s}$

I79 RADHA (KRISHNA'S BELOVED) IN MIDST OF FOREST. DARK TREES IN BACKGROUND. RADHA IS CLOTHED IN RICHLY ORNAMEN'TED GARMEN'TS OF PURPLE AND GOLD, HOLDING TWO GAILY COLOURED BULLRUSHES IN HER HANDS. SHE HAS A GOLD CAP WI'TH PEACOCKS' FEA'THERS ON HER HEAD.

VERY DECORA'TIVE.

Rajput School.

(MEASURING 9 by $6 \frac{1}{2}$ INCHES.)

(India. XVIIIth Century.)

$£ 28$

I8O SULTAN IBRAHIM OF USBECK TARTARY, SEATED BENEATH A TREE, WHO WITH I,600 DAMSELS TO GRACE HIS COURT IN THE CITY OF BALK AND AN ARMY OF I, SO0,000 SUBJECTS, ABANDONED ALL, 'TO BECOME A RELIGIOUS DEVO'TEE IN 'THE' WILDS OF HIS OWN DOMINIONS. THE KING HAS HIS EYES CLOSED IN PIOUS MEDITATION. A GOLDEN HALO SLRROLNDS HIS HEAD. HE IS DRESSED IN LIGHT BLUE TIGHTLY FIT'TING GARMEN'TS. IN FRONT ARE THREE FEMALE ANGELS. THEY HAVE WINGS OF VARIEGATED COLCURS AND ARE RICHLY DRESSED IN SKIRTS; OF PURPLE, LIGH'T GREEN AND CROCUS COLOUR, WITH CLOTH OF GOLD TUNICS COVERED WITH EMBROIDERY. THEY ARE BEARING FOOD FOR THE KING. A VIEW CF THE CITY OF BALK IN THE DISTANCE: THE SKY JS HEAVILY STARRED. A NIGHT SCENE OF SURPASSING BEAUTY.

Rajput School.

(MEASURING 9 by $6 \frac{1}{2}$ INCHES.)

(India. XVIIIth Century.) 
Indian (Rajput School)-continued.

I SOa INDIAN PRINGESS WITH FIVE ATTENDANTS WHIO ARE BEARING FANS, FLY-SWITCHES, E'TC, SITTING ON A COUCH BY THF: BORDER OF AN AR'TIFICIAL LAKE IN WHICH INDIAN DUCKS ARE. SWIMMING, SHE IS SI'TTING WITH HER FEET IN THE WATER AND COOLING THEM BY THE LIGHT OF THE MOON. THREE FOUNTAINS ARE PLAYING IN THIS LAKE. BY THE SIDE OF THE PAVILION IS A CHARMING INDIAN FORMAL GARDEN COVERED WITH DAISIES AND CROSSED BY CANALS OUT OF WHICH FOUNTAINS ARE SPRINGING, RIGHT AT THE BACK IS A SIMILAR VIEW OF AN INDIAN PRINCESS RECLINING ON A COUCH BENEATH A CANOPY OF CLOTH OF GOLD ATTENDED BY SIX LADIES. IN THE DISTANCE IS A VIEW OF THE PALACE WALLS.

Rajput School.

(MEASURING I 2 by 9 INCHES.)

(India. XVIIIth Century).

(See Illustration, Plate No. LxXiV.).

$£ 1818$ s 


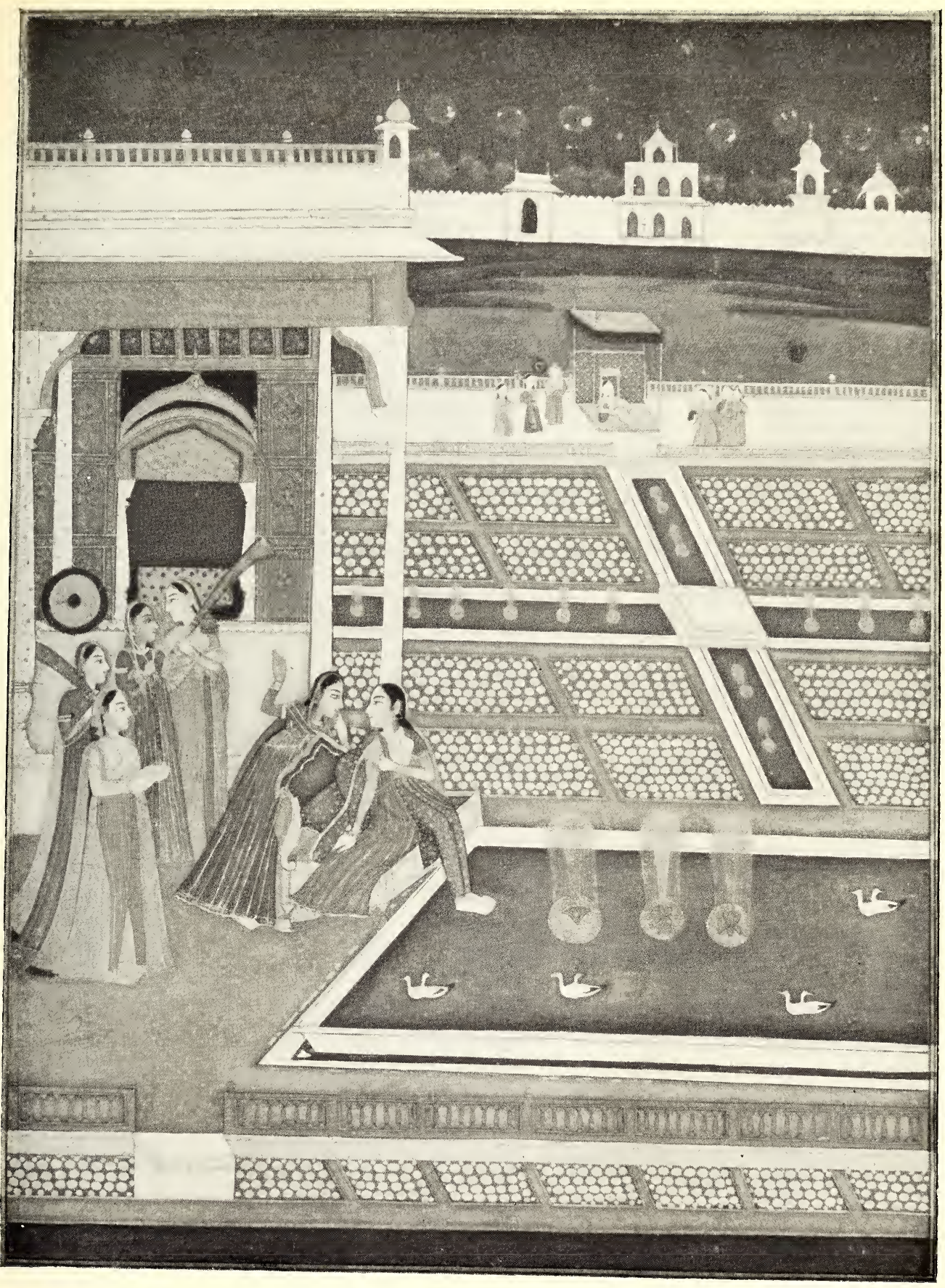

Indian Princess with Attendants.

India. XVIIIth Century.

See Item No. 180a. 


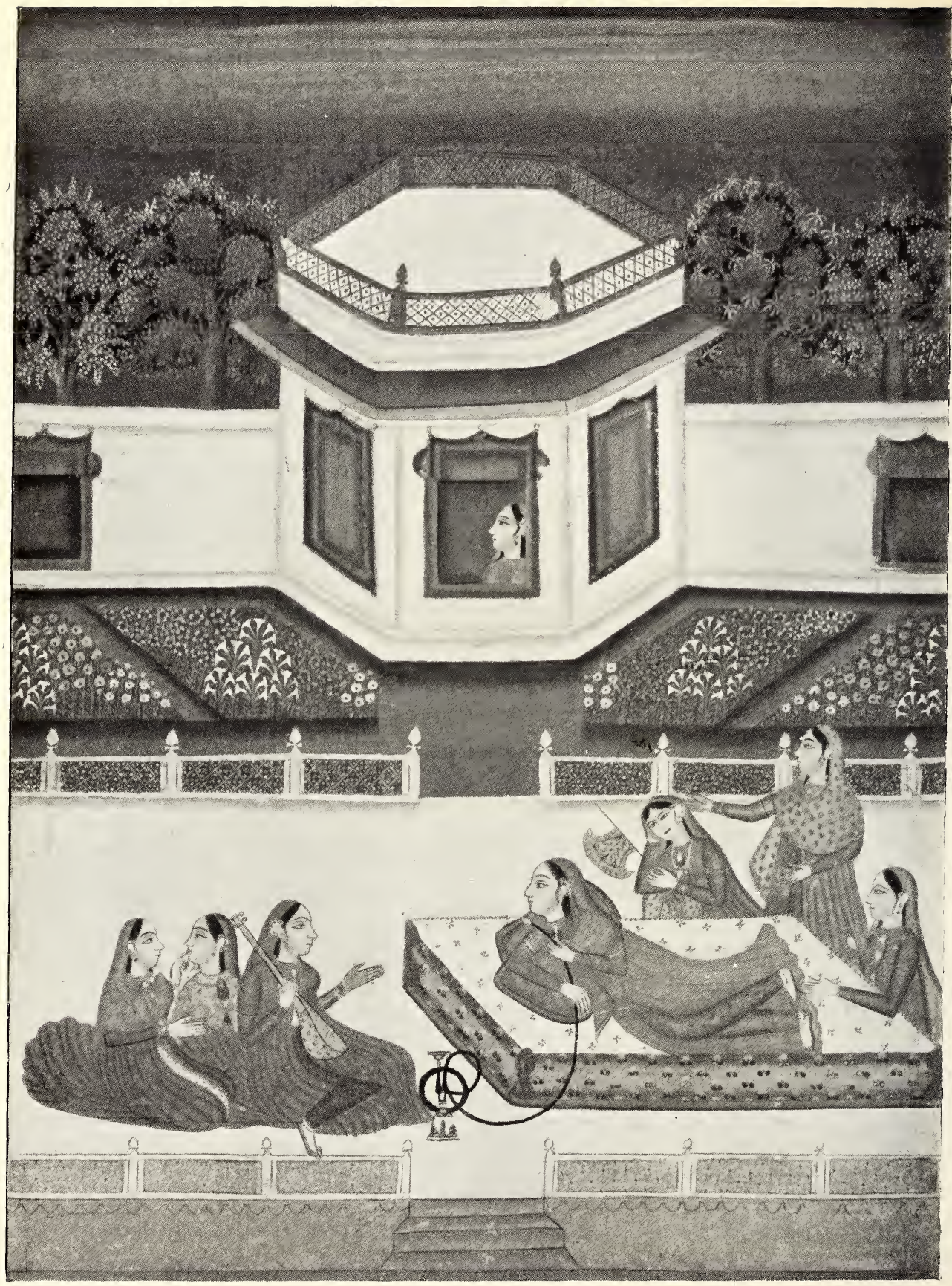

Noble Lady Reclining on a Couch. India. XVIIIth Century. See Item No. 181. 
Indian (Rajput School)-continued.

I8: NOBLE LADY RECLINING ON A COUCH ON THE MADRISA, SMOKING A HOOKAH AND BEING FANNED BY AN ATTENDANT, TURNING ROUND TO CONVERSE WITH A LADY MUSICIAN. IN THE WINDOW OF A HEXAGONAL PAVILION AT THE BACK A LADY IS SEATED LOOKING INTO THE CHARMING GARDEN IN WHICH LILIES ARE GROWING IN GREAT PROFUSION. BEHIND THE GARDEN WALL BEAUTIFUL TREES ARE BLOSSOMING. THE LADIES HAVE THEIR HANDS AND FEE'T STAINED WITH HENNAF.

Rajput School.

(MEASURING I I $\frac{7}{8}$ by $8 \frac{7}{8}$ INCHES.)

(India. XVIIIth Century.)

(See Illustration, Plate No. LxyV.).

$£ 25$

I 82 RADHA (THE BELOVED OF KRISHNA) STANDING ON RIVER BANK, WITH STRINGS OF PEARLS IN EACH HAND, RICHLY GARBED IN GOLD EMBROIDERED SKIR'T, WITH EMBROIDERED FLOWERS IN GREEN AND PURPLE. SURROUNDING HER ARE THREE PEACOCKS. IN BACKGROUND IS A VIEW OF THE RIVER AND BIRDS AND TOWNS ON DISTANT HILLS.

Rajput School.

(MEASURING 9 by $6 \frac{1}{2}$ INCHES.)

(India. XVIIIth Century.)

$£ 25$

"The above is illustrative of the "Rag-Mala, a collection of furty-two allied melodies, known and at once recognized by all educated Hindus. Each of these melodies is understond to be a musical description of a certain pictorial composition, or, as the idea is reversible, each music-picture is a coloured interpretation of the particular melody with which it is associated. In other words, the musician plays from a picture, and the artist paints from a tune. Pictures illustrating the group of Indian muvical compositions known as the Rag-Mala also often issued from the brush of the Pahari painter, and this combination of the two arts of painting and music is of special interest on account of the wide field which a study of this "visualised music" opens up. Jt emphasises, among other things, the peculiar position that the arts generally cccupied in the culture of the people, and the close relation that existed between the different forms of artistic expression." 
Indian (Rajput School)-continued.

THe SPRing Festival.

I 8.3 KRISHNA ON A MADRISA, IN THE SPRING, AT THE CELEBRATION OF THE SPRING FESTIVAL, HE IS SURROUNDED BY A BAND OF SEVEN MUSICIANS, TWELVE O'THER WOMEN, ALL GAILY DRESSED, AND TWO CHILDREN, FOUR OF THE WOMEN ARE BUSILY EMPLOYED IN SQUIRTING HENNAH AT ONE ANOTHER FROM GOLDEN SQUIRTS. BRILLIANTLY ILLUMINATED MINIA'TURE IN GOLD AND COLOURS.

Rajput School.

(MEASURING i3 by io INCHES.)

(India. Late XVIIIth Century.)

(See Illustration, Plate No. LXXVi.).

£22 10s

I84 KRISHNA THE INDIAN DEITY, CROWNED, DANCING WITH RADHA AT THE FEAST. SIX LADY ATTENDANTS, RICHLY DECORATED AND PLAYING MUSICAL INSTRUMENTS DANCING ROUND. ONE IS SQUIRTING SAFFRON ON THE DANCING PAIR. AT BACK, MAGNIFICENT VIEW OF A FOREST WITH GIAN'T CRANES PERCHING ON THE BEAUTIFLLLY PAINTED TREES.

Rajput School.

(MEASURING $8 \frac{1}{2}$ by $6 \frac{1}{2}$ INCHES.)

(India. Late XVIIIth Century.) 


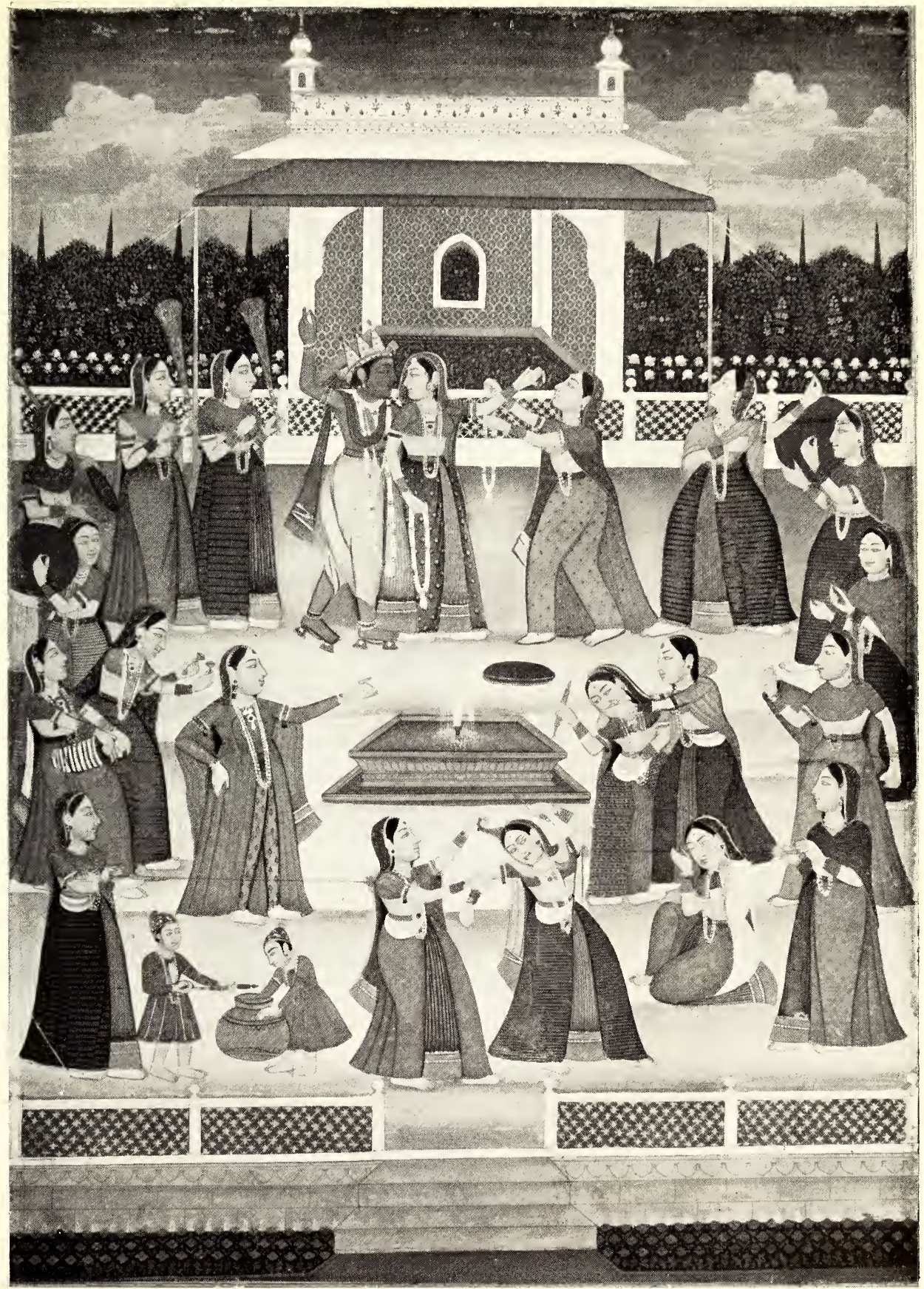

The Siring Festival.

Rajput School.

India. Late XVIIIth Century.

See Item No. 183. 


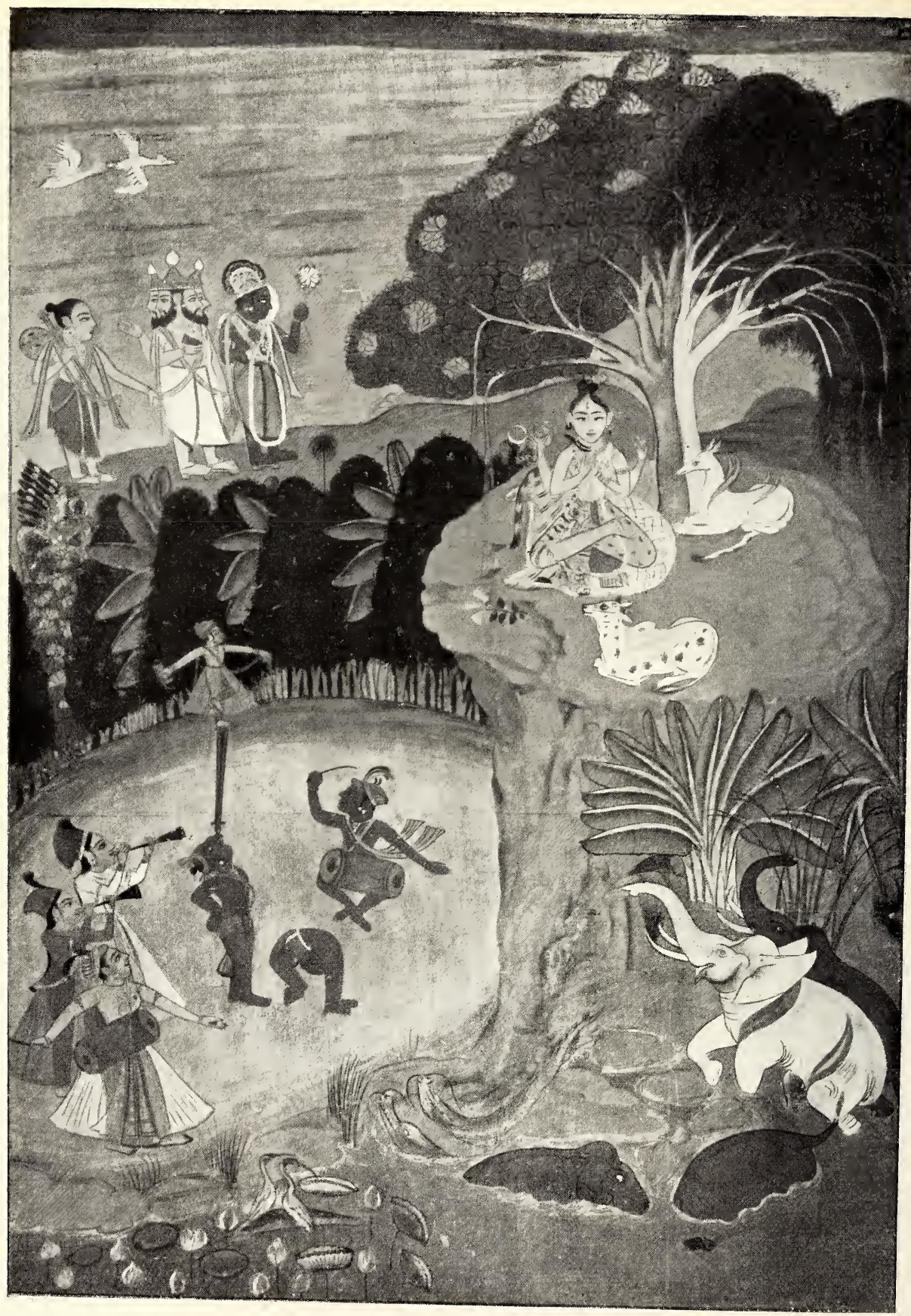

Indian JugGLers.

Rajput School.

India. Late XiIIIth Century.

See Item No 18.5. 
Indian (Rajput School)-continued.

I 85 INDIAN JUGGLERS PERFORMING ON THE LEFT, AT THE BACK ARE THE MANIFESTATIONS OF HINDU DIVINITIES, IN THE FOREGROUND ARE A PAIR OF GREEN CROCODILES ADMIRING THE JUGGLERS, WHILE OUT OF. THE BATHING POND TWO ELEPHAN'TS ONE WHITE AND ONE BLACK CHOR'TLING WITH JOY. CLEVERLY DESIGNED AND PAIN'TED INDIAN MINIA'TURE IN GOLD AND COLOURS.

Rajput School.

(MEASURING io by 7 INCHES.)

(India. Late XVIIIth Century.)

(See Illustration, Plate No. LXXViI.).

$£ 2210$ s

\section{86 SIVARAU HARI.}

PORTRAIT OF SIVARAU HARI SEATED IN CONVERSATION WITH ANOTHER MAN IN A RETIRED NOOK OF HIS HOUSE:

Rajput School.

(MEASURING IO $\frac{3}{4}$ by 7 INCHES.)

(India. XVIIIth Century.)

I87 RADHA (THE LOVER OF KRISHNA) GARBED IN RICH CLOTH OF GOLD GARMENTS WITH A MUSICAL INS'TRUMEN'T ON HER BACK, SEATED IN ADMIRATION BEFORE A LARGE TREE. AT BACK, A VIEW OF A DIS'TAN'T PALACE. IN FRON'T. TWO DUCKS SWIMMING IN A RIVER. THE LADY HAS LOST ONE SHOE.

Rajput School.

(MEASURING 9 by॰ $6 \frac{1}{2}$ INCHES.)

(India. XVIIIth Century.)

The above is illustratuve of the Rag-Mala, a collection of fortr-two aliied melodies, known and at once recognized by all educated Hindus. Each of these melordies is understood to be a musical description of a certain pictorial composition, or, as the idea is reversible, each music-picture is a coloured interpretation, of the particular melody with which it is associated. In other words, the musician plays from a picture, and the artist paint = from a tune. Pictures illustrating the group of Indian musical compositions known as the Rag-Mala also often issued from the brush of the Pahari painter, and this combination of the two arts of painting and music is of special interest on account of the wide field which a study of this "visualised music" opens up. It emphasises, among other things, the peculiar position that the arts generally occupied in the culture of the people, and the close relation that existed between the different forms of artistic expression. 
Indian (Rajput School)_continued.

I87a THE SPRING FESTIVAL. INDIAN PRINCESS SEATED IN A GOLD CHAIR, SMOKING A HOOKAH, WATCHING HER LADIES ENJOYING THEMSELVES IN A PARK. THERE ARE 38 LADIES IN ALL. THREE ARE SWINGING, EIGH'T ARE SEATED IN SWING-BOAT'S, SOME ARE PICKING FRUIT. ONE LADY IS BEING MASSAGED, AFTER TAKING OFF HER SHOES. IN THE BACK-GROUND ARE, GREAT LAKES, ORCHARDS AND HILLS. BEAUTIFULLY EXECUTED IN GOLD AND COLOURS.

Rajput School.

(MEASURING I 2 by I 7 INCHES).

(India. XVIIIth Century).

(See Illustration, Plate No. LXXViIa.).

I 88 KRISHNA STANDING BESIDE A TREE NEAR THE BANKS OF A BBROAD RIVER, ON BOTH SIDES OF HIM ARE COWS, THE LOWER POR'TION OF WHOSE BODIES ARE PAIN'TED WITH HENNAH, AND WHO WEAR GOLDEN BELLS ROUND THEIR NECKS. 'TWO MAIDENS DRESSED IN PURPLE AND GOLD ARE BRINGING HIM TO THE COWS. FLOWERS AND BLOSSOMING 'TREES AND A VIEW OF 'THE DIS'TAN'T PALACES LEND ENCHANTMEN'T TO 'THE VIEW. Rajput School.

(MEASURING I 3 by $9 \frac{1}{2}$ INCHES.)

(India. Late XVIIIth Century.)

$£ 1616 s$

I 89 MOTHER AND CHILD. THE MINIATURE IS CARRIED OUT IN VERY RICH COLOURS. THE CHILD IS GARBED IN CLOTH OF GOLD, AND 'THE MOTHER IS DRESSED IN A RICHLY EMBROIDERED SAFFRON COLOURED DRESS COVERED WITH A GOLD MANTLE. SHE HAS A GOLD HEAD-DRESS AND A GREEN AND VIOLE'T ROBE ROUND HER. THE CHAIR OR SEAT IS EMBROIDERED WITH RED AND BLUE FLOWERS. A'T BACK IS A VIEW OF A GARDEN, LAKE AND MOUN'TAINS, RICHLY DECORATED SKY AND FOREST. THE MINIATURE IS RATHER REMINISCENT OF AN ITALIAN VIRGIN AND CHILD. A RARE EXAMPLE OF EUROPEAN AR'T INFLUENCING INDIAN ART.

Rajput School.

(MEASURING ro by 7 INCHES.)

(India. XVIIIth Century.) 


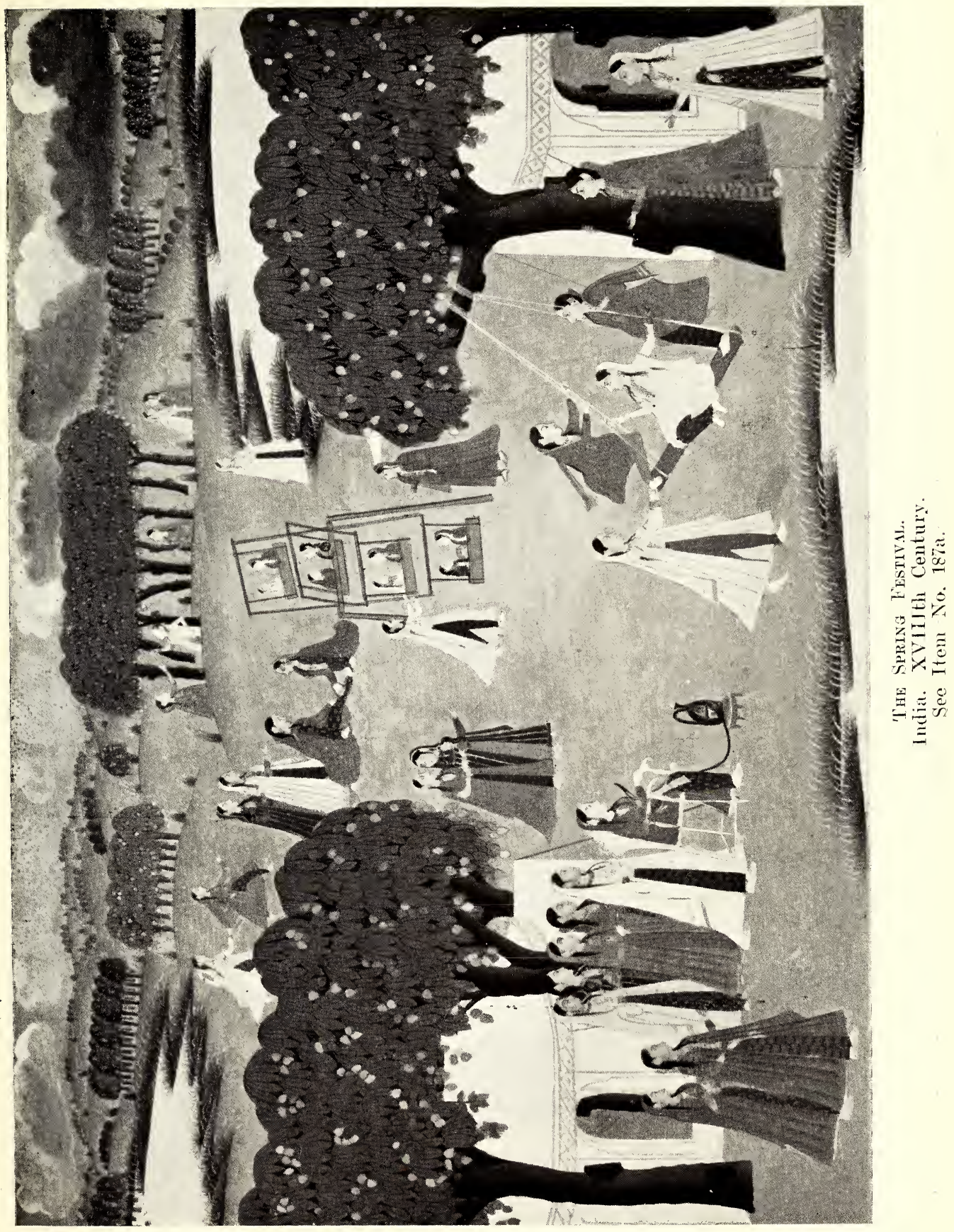




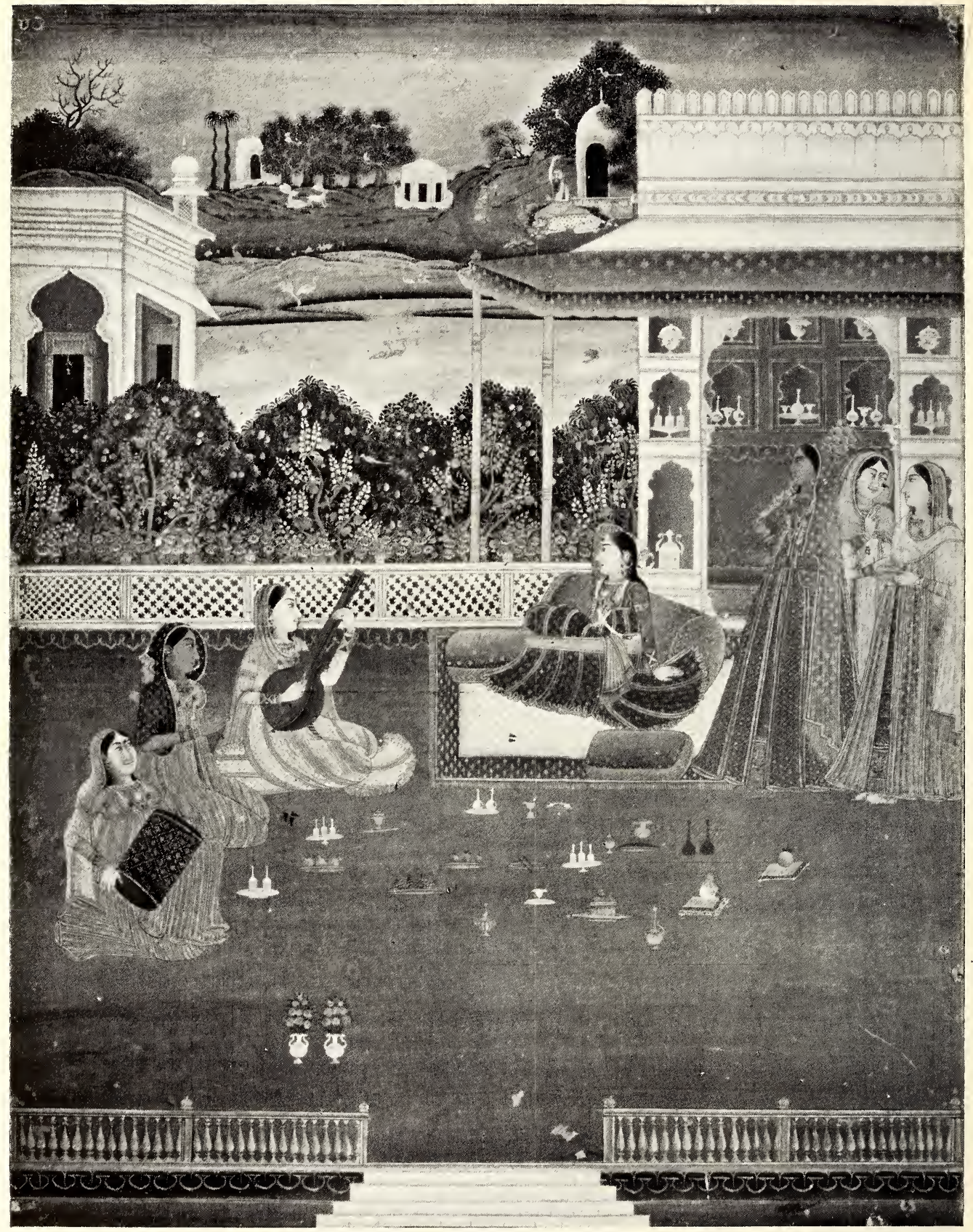

A Lady on a Terrace.

india. XVII!th Century.

See Item No. 189a. 
Indian (Rajput School)_continued.

I89a A LADY ON A MADRISA (TERRACE). IN FRONT OF HER ARE THREE MUSICIANS. BEHIND HER THREE ATTENDANTS. SHE IS RECLINING ON A CARPET, BEFORE HER IS A PAVILION, CONTAINING BEAUTIFUL PORCELAIN, IN THE BACKGROUND IS AN ORCHARD SURROUNDED BY A RIVER IN WHICH ARE WATERFOWL, STILL FURTHER BACK IS A BEAUTIFUL LANDSCAPE IN WHICH A HERMIT (SITTING ON A TIGER-SKIN) IS SMOKING AN EXCEEDINGLY LONG HOOKAH. GAZELLES, PARROTS, CRANES AND NUMEROUS OTHER GAILY COLOURED BIRDS ARE SPORTING NEAR HIM. DAINTILY CARRIED OUT IN GOLD AND COLOURS.

Rajput School.

(MEASURING 12 by $9 \frac{1}{2}$ INCHES)

(India. XVIIIth Century).

(See Illustration, Plate No. LXXviII.).

$£ 1616 \mathrm{~s}$

Igo INDIAN PRINCE, KNEELING BEFORE PRINCESS SITTING ON RAISED COUCH. TWO LADY ATTENDANTS. A'T BACK, VIEW OF TERRACE PAVILICN, SURROUNDED BY TREES.

Rajput School.

(MEASURING 9 by $6 \frac{1}{2}$ INCHES.)

(India. Early XVIIIth Century.)

$£ 1515 s$

The above is illustrative of the Rag-Mala, a collection of forty-two allied melodies, known and at once recognized by all educated Hindus. Each of these melodies is understood to be a musical description of a certain pictorial composition, or as the idea is reversible, each music-picture is a coloured interpretation of the particular melody with which it is associated. In other words, the musician plays from a picture, and the artist paints from a tune. Pictures illustrating the group of Indian musical compositions known as the Rag-Maia also often issued from the brush of the Pahari painter, and this combination of the two arts of painting and music is of special interest on accourt of the wide field which a study of this "visualised music" opens up. It emphasises, among other things, the peculiar position that the arts generally occupied in the culture of the peopile, and the close relation that existed between the different forms of artistic expression. 
Indian (Rajput School)-contimued.

IgOa KRISHNA. KRISHNA STANDING ON A TERRACE IN THE MIDDLE OF A BEAUTIFUL GARDEN, FULL OF GAILY COLOURED FLOWERS, AND FRUIT-TREES, SURROUNDED BY NINE LADIES, IN THE BACKGROUND IS A PAVILION, IN FRONT OF WHICH ARE FOUNTAINS ANI BEDS OF RED AND YELLOW FLOWERS. BEAUTIFULLY ILLUMINATED MINIATURE IN GOLD AND COLOURS WITHIN A DAINTY FLORAL BORDER.

Rajput School.

(MEASURING I4 by I I INCHES).

(India. Late XVIIIth Century).

(See Illustration, Plate No. LXXiX.).

$£ 31$ 10s:

I9I A HOLY WOMAN, REPOSING UNDER A TREE. FOUR ATTENDANTS. ON HER LEFT. AT BACK, HER BUFFALO CAR'T. RICH LANDSCAPE. IN FOREGROUND, A POOL, COVERED WITH FLOWERING LOTUS AND LOTUS LEAVES. AT BACK, VIEW OF SETTING SUN AND BIRDS SITTING ON THE TREES.

Rajput School.

(India. XVIIÎth Century).

$£ 2210 \mathrm{~s}$

I92 PORTRAIT OF KAIM KHAN, SON OF RANSHAN-UL-DAWLAH. THE PRINCE IS CONTEMPLATING A FLOWER. HE IS RICHLY DRESSED IN PURPLE AND GOLD AND IS SITTIN'G ON A FINELY EMBROIDERED PERSIAN CARPET. BEHIND HIM IS A MURCHAL BEARER, HOLDING HIS HANDKERCHIEF. ABOVE THE HEADS OF THE TWO IS A FINELY EMBROIDERED CANOPY. BEHIND IS A VIEW OF THE GARDEN WITH PURPLE AND RED FLOWERS. A VERY DECORATIVE MINIATURE.

Rajput School.

(India. XVIIIth Century). 


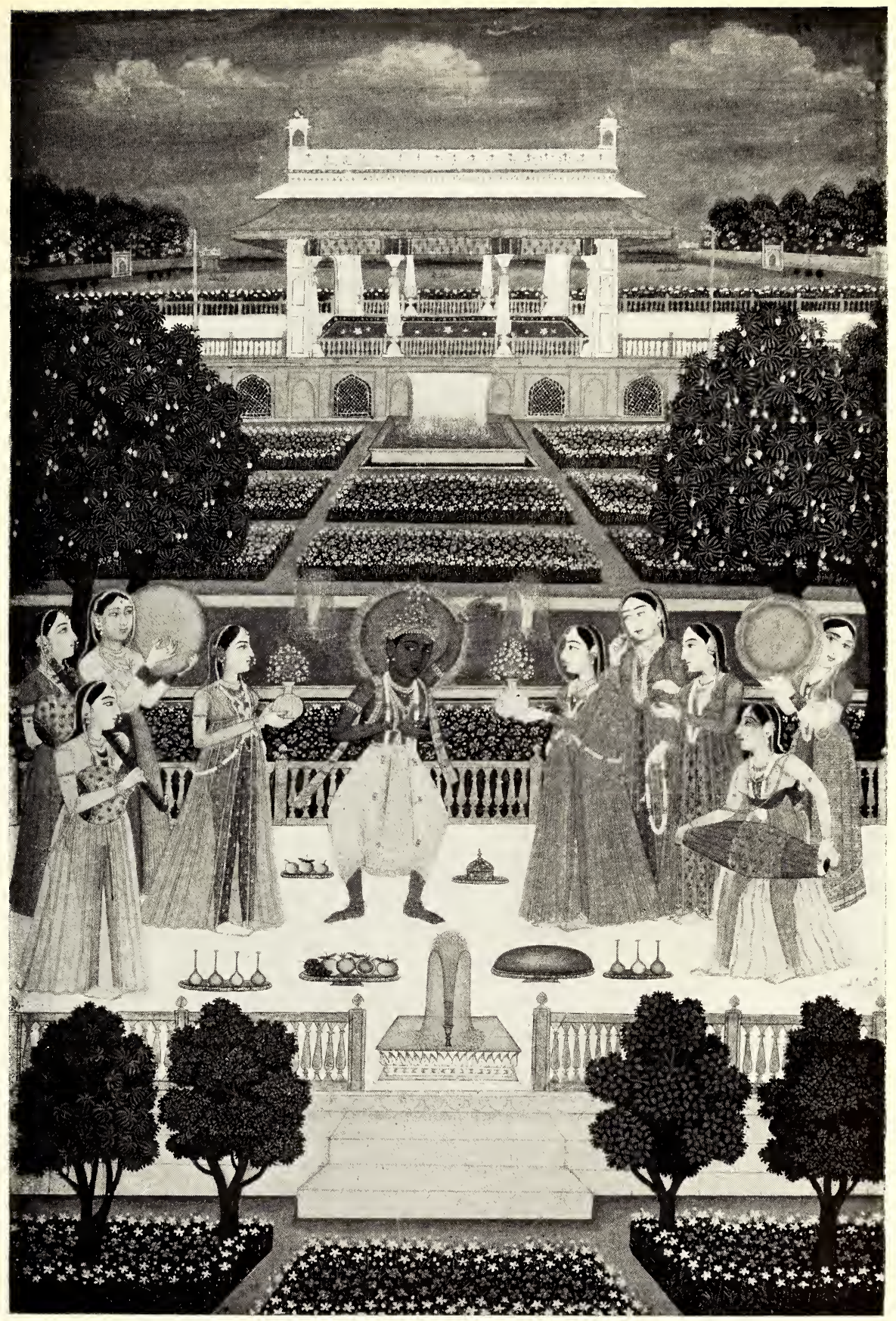

Krishna in the Girden.

Rajput Schooí.

India. XVIIIth Century.

See Ttem No. 190a. 
Plate LXXX.

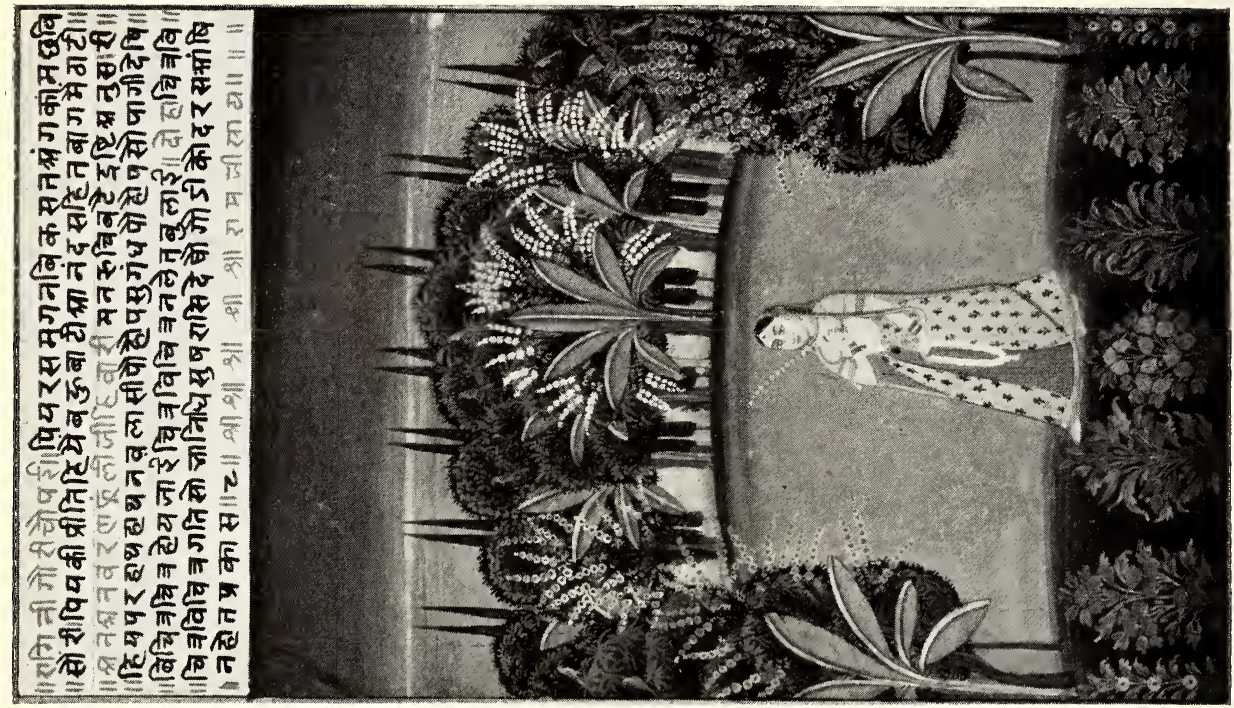

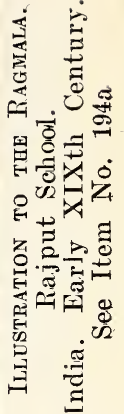

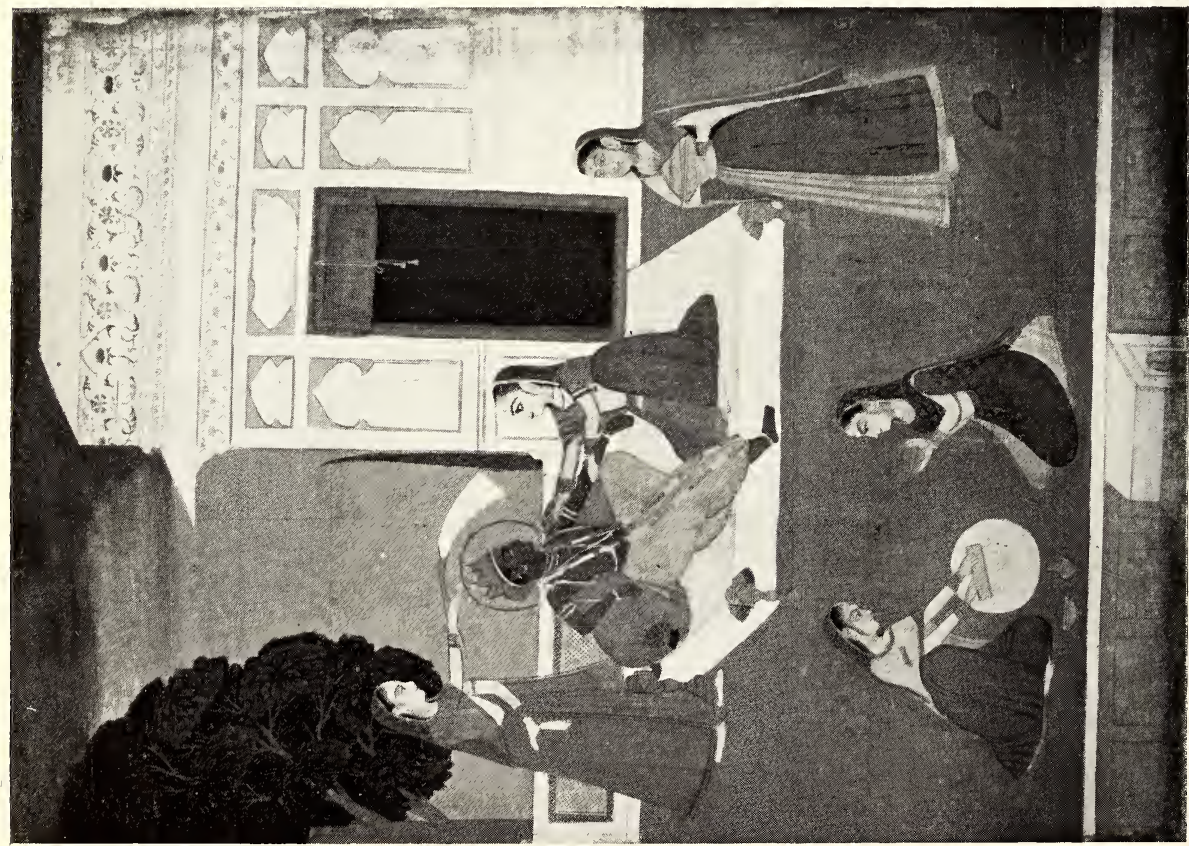



富

A- ت्व்

วิ

-

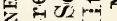

到考

类.

凷

党

红

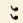


Indian (Rajput School)-continued.

I94 KRISHNA, CROWNED, SIT'TING ON RAISED DIVAN, WITH LADY. FAN BEARER AT BACK AND THREE LADY AT'TENDANTS IN FRON'T PREPARING A MEAL. VIEW OF GARDEN PAVILION AT BACK AND TREES. VERY FINE.

Rajput School.

(MEASURING 9 by $6 \frac{1}{2}$ INCHES).

(India: XVIIth Century).

(See Illustration, Plate No. LXXX.).

$£ 20$

I94a RAGMALA. ILLUSTRATIONS OF THE 48 RAGMALA.S. I 7 RAJPUT MINIATURES OF INDIAN SCENES, SANSKRIT TEXT, BEAUTIFULLY PAINTED IN GOLD AND COLOURS. THE MINIATURES ILLUSTRATE RAGMALAS Nos. 4, 5, 6, 8, 9, I I, I 2, I 4, I 5, I6, I 8, 20 , 22, 25, 28, 29, 33.

Raiput School.

(MEASURING 9 by 6 INCHES).

(India. Early XIXth Century).

(See Illustratici, Plate No. LXXX.).

$£ 31$ 10s

I94b NADIR SHAH. A PORTRAIT EXECUTED IN GOLD AND COLOURS OF NADIR SHAH. HE IS RECLINING ON A CARPET AND HOLDING HIS SWORD WITH BOTH HANDS. ROUND HIS NECK HE WEARS AN EMERALD CHAIN.

Rajput School.

(MEASURING $8 \frac{1}{2}$ by 7 INCHES).

(India. XVIIIth Century). 
Indian (Rajput School)-continued.

I95 QUEEN, WITH RICH RINGS OF PEARLS ROUND HER NECK AND FEET, SEATED IN AN ORNAMENTAL CHAIR. THE LADY IS CLOTHED IN A RICHLY EMBROIDERED CHRYSANTHEMUM COLOURED GARMENT. HER ATTENDANTS ARE CLOTHED IN BLUE, GREEN AND CROCUS COLOURED GARMENTS.

THE MINIATURE IS SURROLNDED BY A BORDER OF FLOWERS, AND HAS A VERY DECORATIVE EFFECT.

Rajput School.

(MEASURING Io by $\delta$ INCHES).

(India. About I750.)

(See Illustration, Plate No. LXXXi.).

$£ 1212 \mathrm{~s}$

\section{I96 HAWKING.}

A LADY ABOUT TO SEND HER FAVGURITE HAWK TO CATCH SOME BIRDS IN 'THE DISTAN'T BACKGROUND. IN FRON'T IS A SILVER POOL WITH LOTUSES GROWING ON THE SURFACE. A CHARMING INDIAN MINIATURE.

Rajput School.

(MEASURING 7 by 5 INCHES.)

(India. XVIIIth Century.)

$£ 12$ 10s

The following note from "Brown's Indian Painting." can be held to refer to the above miniature. "A silver priming was al*o u-ed, especially in connection with the representation of still water over which lotus flowers and other aquatic plants were painted."

I 97 MINIATURE OF A LADY SEATED ON THE GRASS PLAYING A MUSICAL INSTRUMENT, BY HER SIDE TWO APPLES, A FLASK AND A GOLDEN WINE-CUP.

Rajput School.

(MEASURING 8 by 5 INCHES.)

(India. XVIIIth Century:)

$£ 12$ 10s

igS STORY TELLING. A LADY WRAPPED IN WINTER ROBES SEATED IN THE ALCOVE OF A PALACE LISTENING TO A FEMALE STORYTELLER, SQUATTING BEFORE HER, AND ANOTHER WOMAN STANDING BY. THE CARPE'T IS OF A VERY INTERESTING PATTERN.

Rajput School.

(MEASURING $8 \frac{7}{8}$ by $5 \frac{1}{2}$ INCHES.)

(India. XVIIIth Century.) 


\section{Plate LXXXI.}

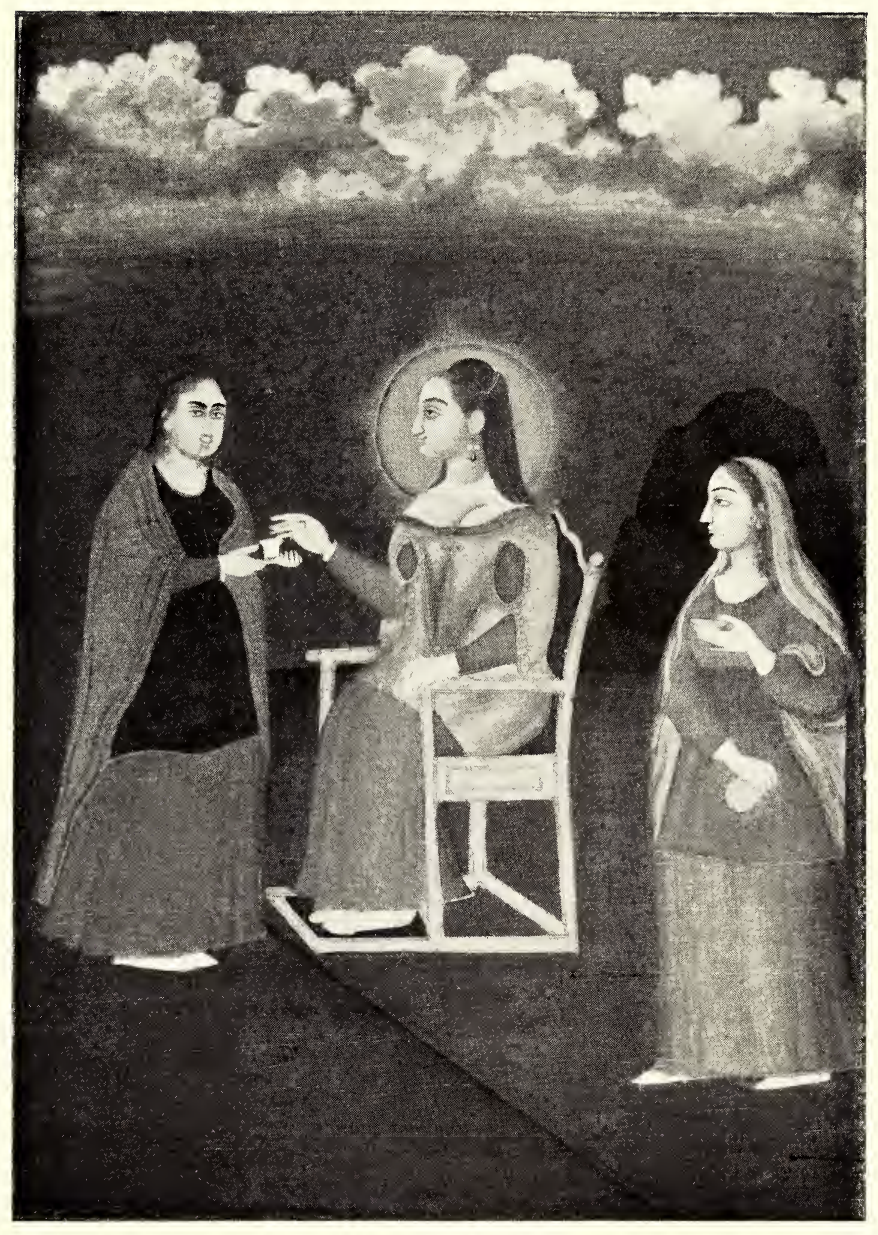

Quees, with rich rows of pearls.

Miniature. (GreaÆly reduced.)

Rajput Schoel.

India. About A.1), 1750

See Iten No. 19.5. 


\section{Plate LXXXII}

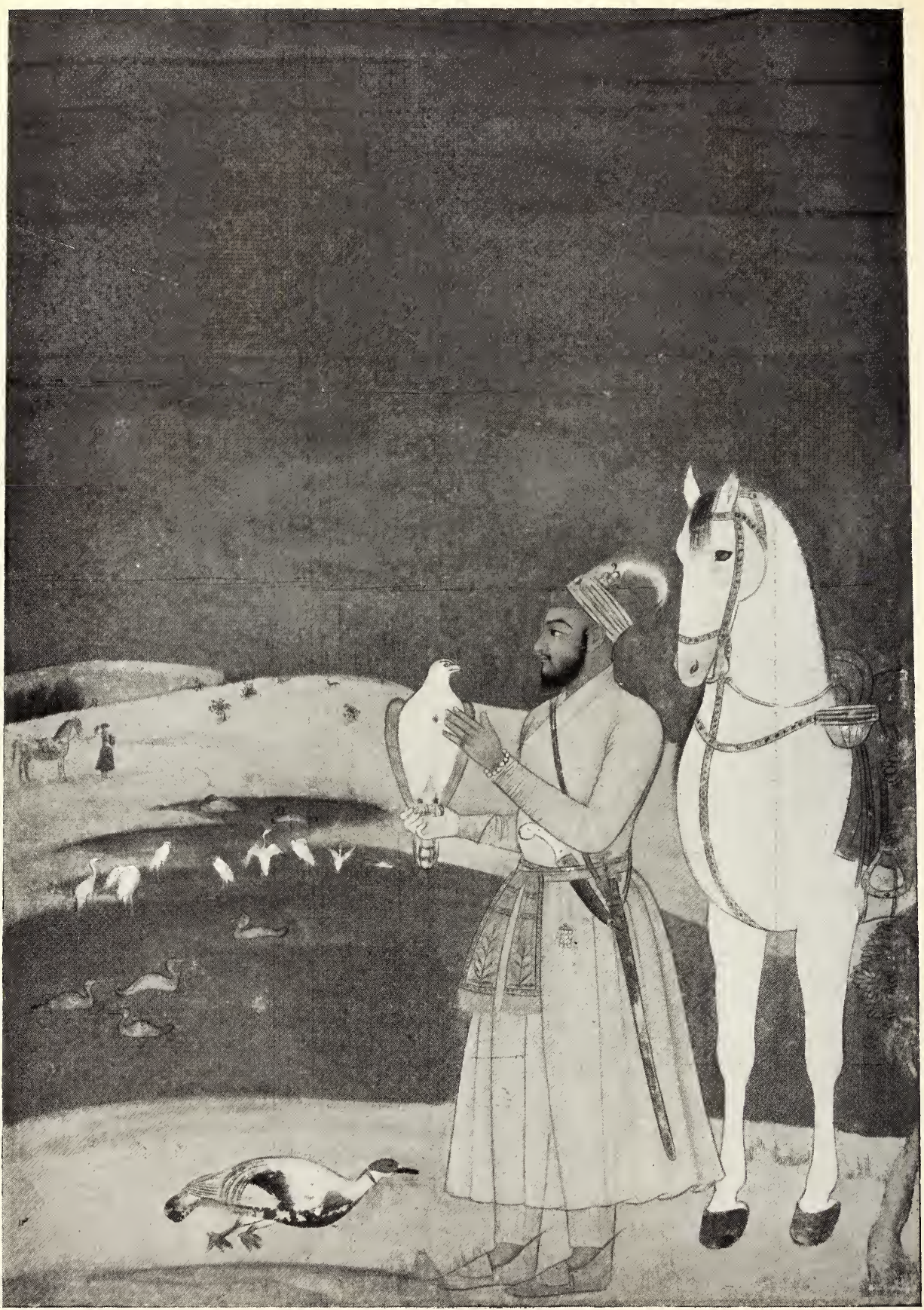

Mirza Abul fíassam.

Rajput School.

India. About A D, 1700

See Item No. 198a 
Indian (Rajput School)_continued.

ig8a MIRZA ABUL hASSAM STANDING BY A LAKE WHERE WATERFOWL ARE CONGREGATED, HOLDING A HAWK, HIS WHITE HORSE STANDING BEHIND HIM. BEAUTIFUL INDIAN MINIATURE.

Rajput School.

(SIZE IO $\frac{1}{2}$ by $7 \frac{1}{2}$ INCHES.)

(India. About A.D. I700.)

(See Illustration, Plate No. LxyXit.).

$£ 1610 \mathrm{~s}$

\section{I99 THE GOLDEN AGE.}

KRISHNA SITTING AT THE OPEN BALCONY OF A PALACE IN A GARDEN, BELOW ARE THIRTEEN FOUNTAINS; A SNAKE, A PEACOCK, CURIOUSLY COLOURED DUCKS, ANTELOPES, TIGERS, CRANES, ELEPHANTS, AND GAZELLES, ARE LIVING AT PEACE. CHARMINGLY COLOURED MINIATURE.

Rajput School.

(MEASURING I I by 8 INCHES.)

(India. Early XVIIIth Century.)

$£ 1010$ s

\section{TWO PRINCES HAWKING.}

DELICATE DRAWING LIGHTLY TIN'TED.

Rajput School.

(MEASURING 6 by 5 INCHES.)

(India. XVIIIth Century.)

$£ 10$ 10s: 
Indian (Rajput School)-continued.

200a IDYLL AT THE WELL. AN INDIAN PRINCE MOUN'TED ON A FINE WHITE HORSE GAILY CAPARISONED, ATTENDED BY THREE MEN, IS RECEIVING WATER IN A CUP FROM AN INDIAN DAMSEL STANDING ROUND THE MOU'TH OF A WELL. SIX OTHER INDIAN LADIES ARE OCCUPIED IN GETTING WATER FROM THE WELL AND IN CONVERSATION. ALL ARE GAILY DRESSED AND COVERED WITH PEARLS AND JEWELLERY. THE BACKGROUND A FOREST OF PALMS AND O'THER TREES IS BEAUTIFULLY INDICATED, OVER WHICH THE SUN IS SETTING. BRILLIANTLY ILLUMINATED MINIATURE IN GGLD AND COLOURS.

Rajput School.

(MEASURING I 2 by io JNCHES).

(India. Late XVIIIth Century).

(See Illustration, Plate No. LXXXiII.).

£31 10s

\section{OI A MIDDAY REST.}

CHARMING DRAWING, DELICATELY TINTED, OF A MIDDAY HALT BY THE ROADSIDE. THE TRAVELLERS ARE PICTURESQUELY GROUPED, THE LORD AND MASTER OF THE SMALL CARAVAN IS INDOLENTLY RECLINING WHILE AN ATTENDANT IS MASSAGING HIS FEET. A LUGGAGE-BULLOCK, A HORSE (WHICH IS DRINKING OUT OF A BUCKET SLUNG OVER ITS EARS), AND TWO CAMELS ARE LYING ROUND ABOUT." FINE SPECIMEN OF CALLIGRAPHY ON BACK.

Rajput School.

(MEASURING $6 \frac{1}{2}$ by 9 INCHES.)

(India. XVIIIth Century.) 


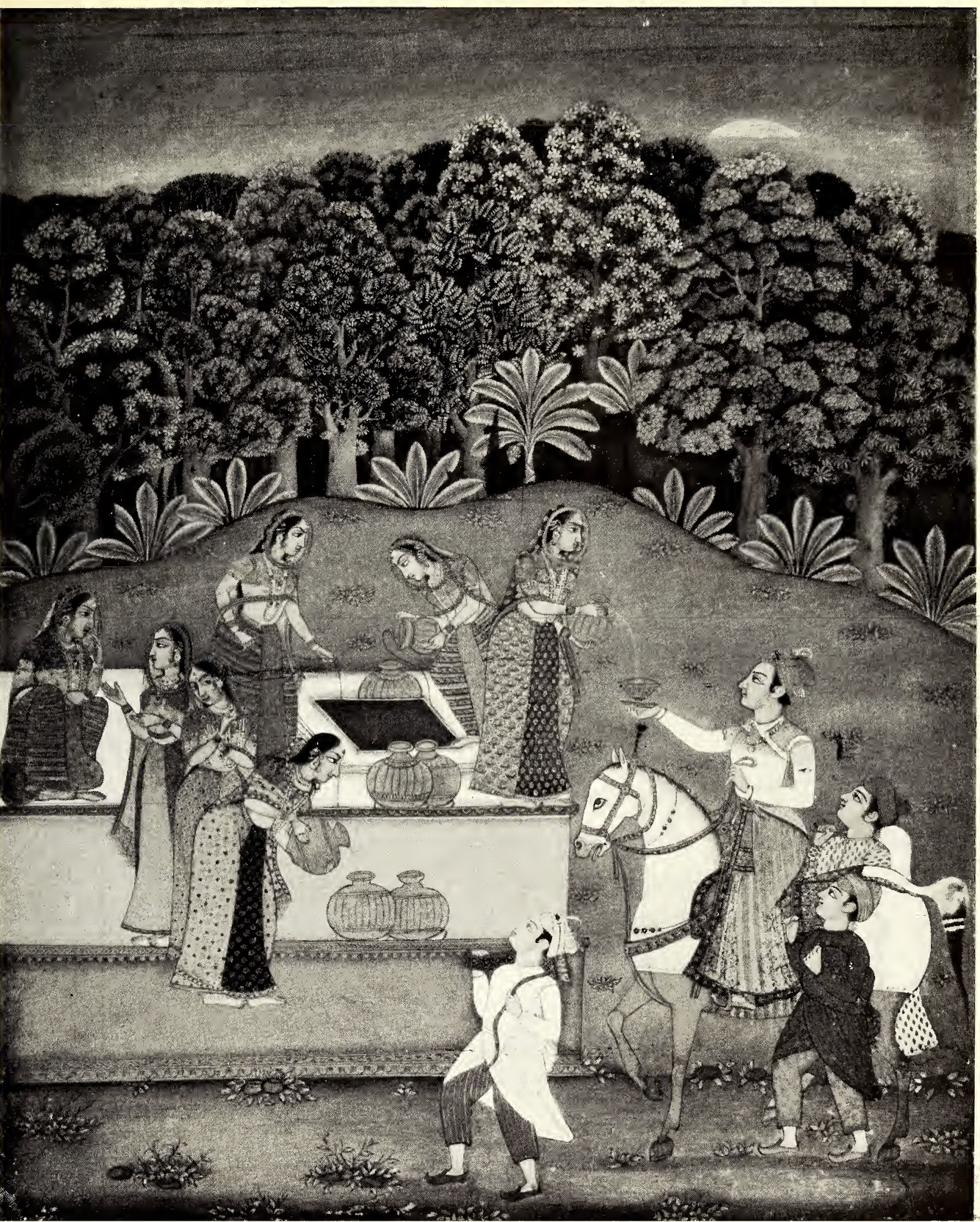

Idyll at the Well.

Rajput School.

India. Late XVIIIth Century.

See Item No. 200a 


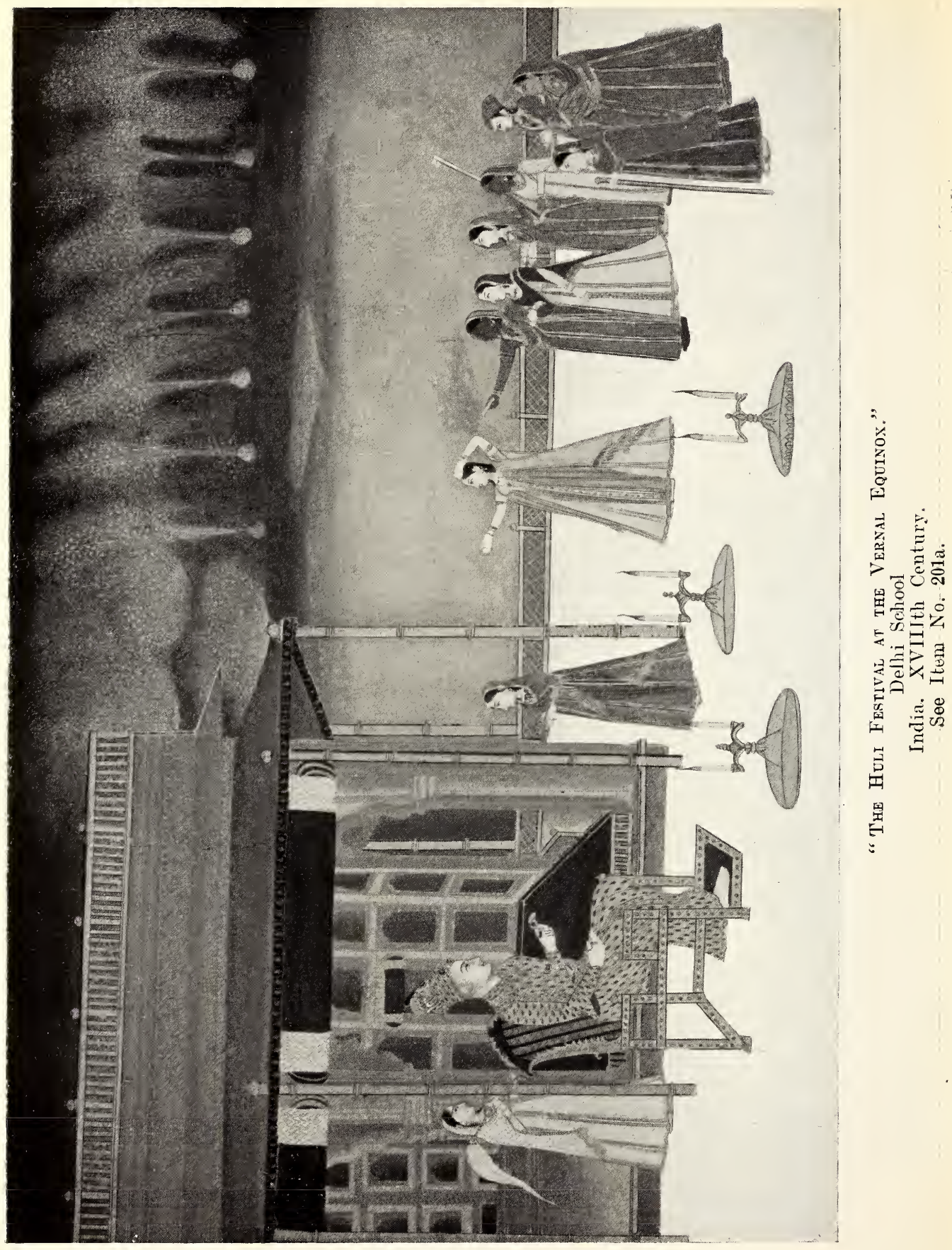


Indian (Rajput School)_continued.

\section{OIa THE HULI FESTIVAL AT THE VERNAL EQUINOX.}

A PRINCE SEATED UNDER AN AWNING BESIDE A PALACE HOLDING A JEWELLED AIGRET'TE AND WATCHING THE PERFORMANCE OF A FEMALE DANCER AND SEVEN MUSICIANS, WITH CANDLES LIGHTING THE SCENE, IN THE DISTANCE FIREWORKS ARE RISING IN THE AIR FROM BEHIND SHRUBBERY.

Delhi School.

(MEASURING I $1 \frac{3}{4}$ by i 7 INCHES).

(India. XVIIIth Century).

(See Illustration, Plate No. LXXXiv.).

202 AN INDIAN RULER SIT'TING WITH A HAWK ON HIS GLOVED RIGHT HAND, BENEATH A STATE PARASOL. MINIATURE IN GOLD AND COLOURS.

Rajput School.

(MEASURING 7 , by 5 INCHES.)

(India. XVIIIth Century.)

$£ 810 \mathrm{~s}$

203 A LADY ENTERTAINED, IN A QUADRANGLE, AND LADIES IN WINDOWS OF THE WALLS IN THE BACKGROUND, BEYOND WHICH IS A GROVE OF TREES AND A PAVILION.

Rajput School.

(MEASURING $7 \frac{1}{2}$ by $7 \frac{5}{8}$ INCHES:)

(India. XVIIIth Century.)

$£ 88 \mathrm{~s}$

\section{MAJNUN WITH HIS DOG IN THE DESERT.}

WITH A FINE BORDER OF FOYES, ANTELOPES, GAZELLES, CROWS, TIGERS, ETC.

DELICATE INDIAN DRAWING, LIGHTLY TINTED. FINE SPECIMEN OF CALLIGRAPHY ON BACK.

Rajput School.

(MEASURING 6 by 7 INCHES.) (Wormed.)

(India. XVIIIth Century.) 
Indian (Rajput School)-continued.

204a CHURR US EATERS. A GROUP OF SIXTEEN MEN UNDER A TREE, OUTSIDE A HUT, ENGAGED IN EATING OR PREPARING CHURRUS (A RESINOUS PRODUCT OF HEMP), AND ONE IN THE FOREGRCUND PLAYING A MUSICAL INSTRUMENT. INDIAN MINIATURE CAREFULLY EXECUTED IN SUBDUED COLOURS.

Kangra School.

(MEASURING i 2 by $7 \frac{1}{4}$ INCHES).

(India. XVIIIth Century).

(See Illustration, Plate No. LXXXV.).

205 INDIAN RULER SEATED ON HIS THRONE, A FLY-SWITCH IN HIS HAND, RICHLY COVERED WITH GOLD AND JEWELS, ABOVE HIS HEAD IS A GOLD STATE PARASOL. HANDSOMELY PAINTED IN GOLD AND COLOURS.

Rajput School.

(MEASURING $8 \frac{3}{4}$ by $5 \frac{3}{4}$ INCHES.)

(India. XVIIIth Century.)

$£ 7$ 7s

205 INDIAN RULER SEATED ON HIS THRONE, A JEWELLED ORNAMEN'T IN HIS HAND, HE IS DRESSED IN LIGHT GREEN, ABOVE. HIS HEAD IS A GOLD STATE PARASOL. HE IS COVERED WITH GOLD JEWELS AND IS BLACK BEARDED. HANDSOMELY PAIN'TED IN GOLD AND COLOURS.

Rajput School.

(MEASURING 8 by 6 INCHES.)

(India. XVIIIth Century.)

$£ 7$ 7s

207 INDIAN R ULER SEATED ON HIS 'THRONE, A JEWELLED ORNAMEN'I' IN HIS HAND HE IS DRESSED IN ORANGE, ABOVE HIS HEAD IS A GOLD STATE PARASOL. HE IS COVERED WITH GOLD AND JEWELS AND IS BEARDLESS. HANDSOMELY PAINTED IN GOLD AND COLOURS.

Rajput School.

(MEASURING $8 \frac{1}{2}$ by 6 INCHES.)

(India. XVIIIth Century.) 


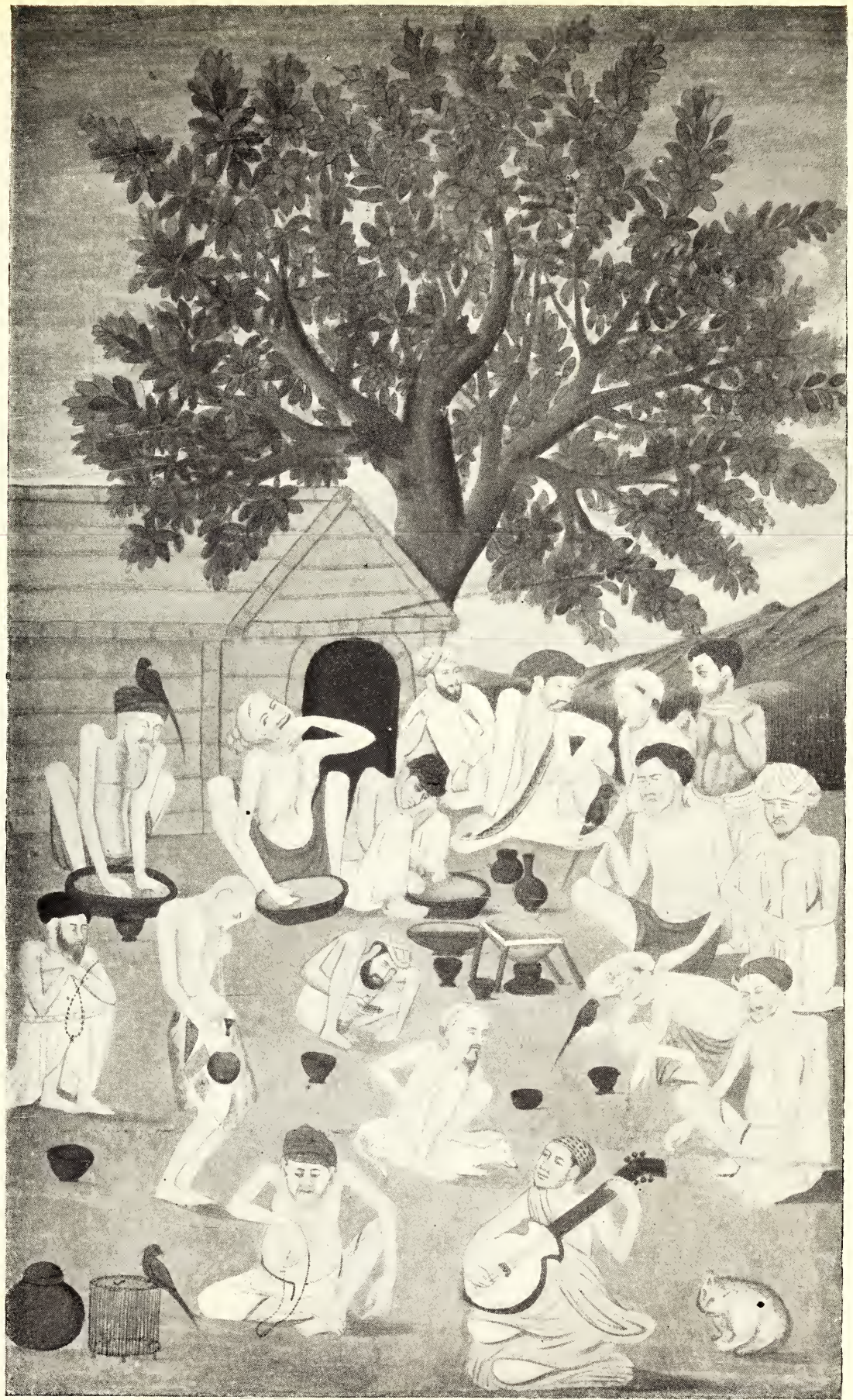

The Cherres Eaters.

Rajput School.

India. XVIIth Century

See Item No. 204a. 


\section{Plate LXXXVI.}

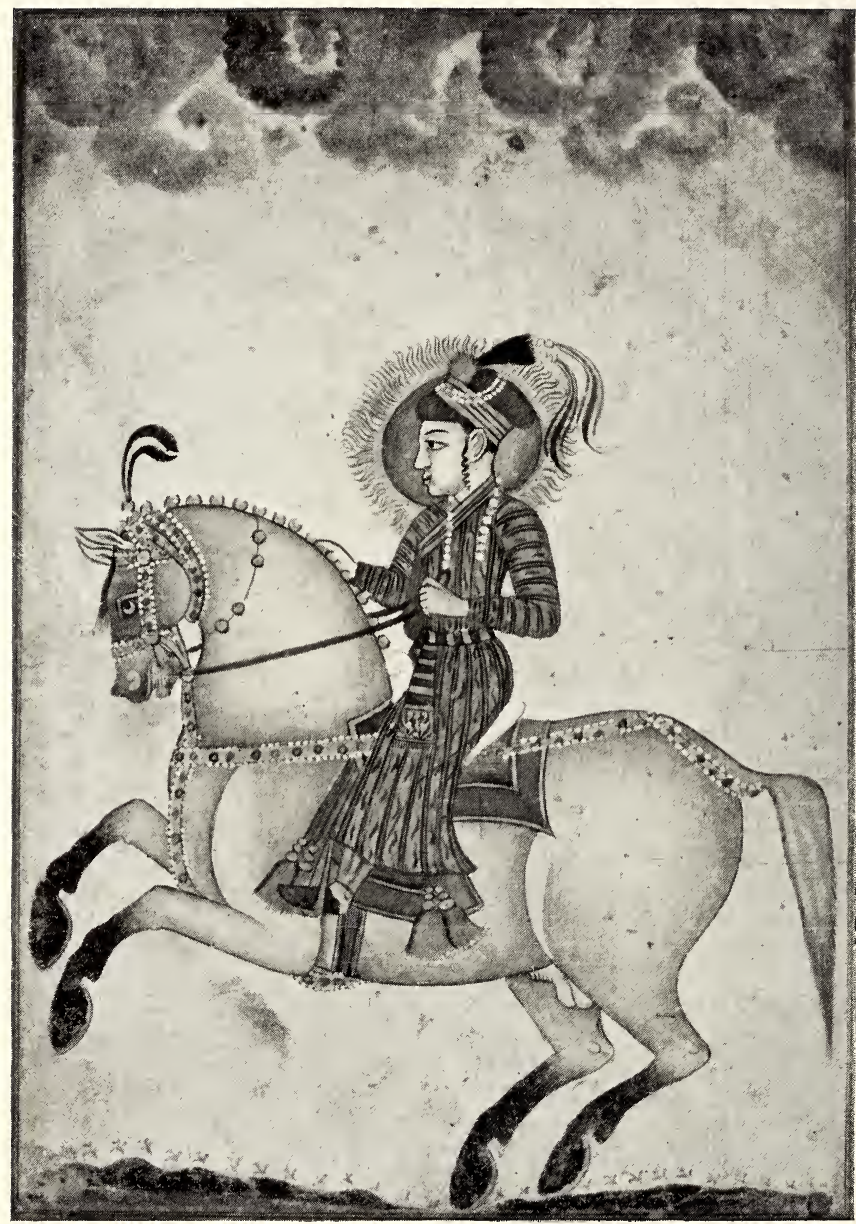

Portrait (reduced) of RaJAH JAggut Singh, of Udapur. Rajput School.

XVIIIth Century.

See Item No. 207a. 
Indian (Rajput School)-continued.

207a PORTRAit OF RAJAH JAGGUt SINGH, THE RULER OF UDAPUR. THE RAJAH IS REPRESENTED SITTING ON A HORSE WHICH IS PRANCING ABOUT.

VERY INTERESTING DRAWING IN HEIGHTENED COLOURS.

Rajput School.

(MEASURING 9 by 7 INCHES).

(India. XVIIIth Century).

(See Illustration, Plate No. LXXXVi.).

$£ 7$ 10s

\section{MAHARAJA RAJA SINGH OF BIKANIR.}

A PORTRAIT EXECUTED IN GOLD AND COLOURS OF THE MAHARAJA IN WHITE DRESS AND GORGEOUS TURBAN, ADMIRING A ROSE.

Rajput School.

(MEASURING 8 by $5 \frac{1}{2}$ INCHES.)

(India. I787.)

£5 5s

209 INDIAN RULER SEATED ON HIS THRONE, A JEWELLED ORNAMENT

IN HIS LEFT' HAND, AN AXE JN HIS RIGHT, HE IS DRESSED IN CLO'T'H OF GOLD, ABOVE HIS HEAD IS A GOLD STATE PARASOL. HIS HAT IS COVERED WITH PEARLS. HANDSOMELY PAINTEL IN GOLD AND COLOURS.

Rajput School.

(MEASURING $8 \frac{1}{2}$ by $5 \frac{1}{2}$ INCHES).

(India. XVIIIth Century).

$£ 77 \mathrm{~s}$

2IO MAHARAJA SURAT SINGH OF BIKANIR.

A PORTRAIT EXECUTED IN GOLD AND COLOURS OF THE MAHARAJA IN WHITE DRESS AND GORGEOUS TURBAN, STANDING ON THE MADRISA.

Rajput School.

(MEASURING IO $\frac{1}{2}$ by 7 INCHES).

(India. I787).

$£ 6$ 6s 
Indian (Rajput School)-continued.

2 IOA PORTRAIT OF AN INDIAN NOBLE CONTEMPLATING A ROSE, HE IS HOLDING A SWORD IN HIS LEFT HAND. PAINTED ON A LIGHT BROWN BACKGROUND.

Rajput School.

(MEASURING 8 by $4 \frac{1}{2}$ INCHES).

(India. XVIIIth Century).

(See Illustration, Plate No. LyxXVii.).

2I I INDIAN HOLY MAN, DELICATELY DRAWN INDIAN DRAWING, ENTIRELY NUDE EXCEPT FOR A GIRDLE ROUND HIS WAIST, WITH LONG HAIR AND BEARD.

Rajput School.

(MEASURING 7 by $4 \frac{1}{2}$ INCHES).

(India. XVIIIth Century).

2 I2 AN INDIAN LADY IN RICH CLOTH OF GOLD AND PURPLE GARMENTS, A VEIL OVER HER HEAD, HOLDS A LIGHT IN HER RIGH'i' HAND, STANDING BY A PALACE DOOR. HANDSOMELY PAIN'TED IN GOLD AND COLOURS.

Rajput School.

(MEASURING $6 \frac{1}{2}$ by $4 \frac{1}{2}$ INCHES).

(India. XVIIIth Century).

$£ 3$ 3s

\section{I6 RAJA BAJI SINGH OF JODHPUR.}

A PORTRAIT EXECUTED IN GOLD AND COLOURS OF RAJA BAJI OF JODHPUR, IN WHITE DRESS, WEARING A FINE TURBAN, HOLDING A STRING OF BEADS IN HIS RIGHT HAND, A SWORD AT HIS SIDE.

Rajput School.

(MEASURING Io $\frac{1}{4}$ by $6 \frac{7}{8}$ INCHES).

(India. XVIIIth Century). 


\section{Plate LyXXViI.}

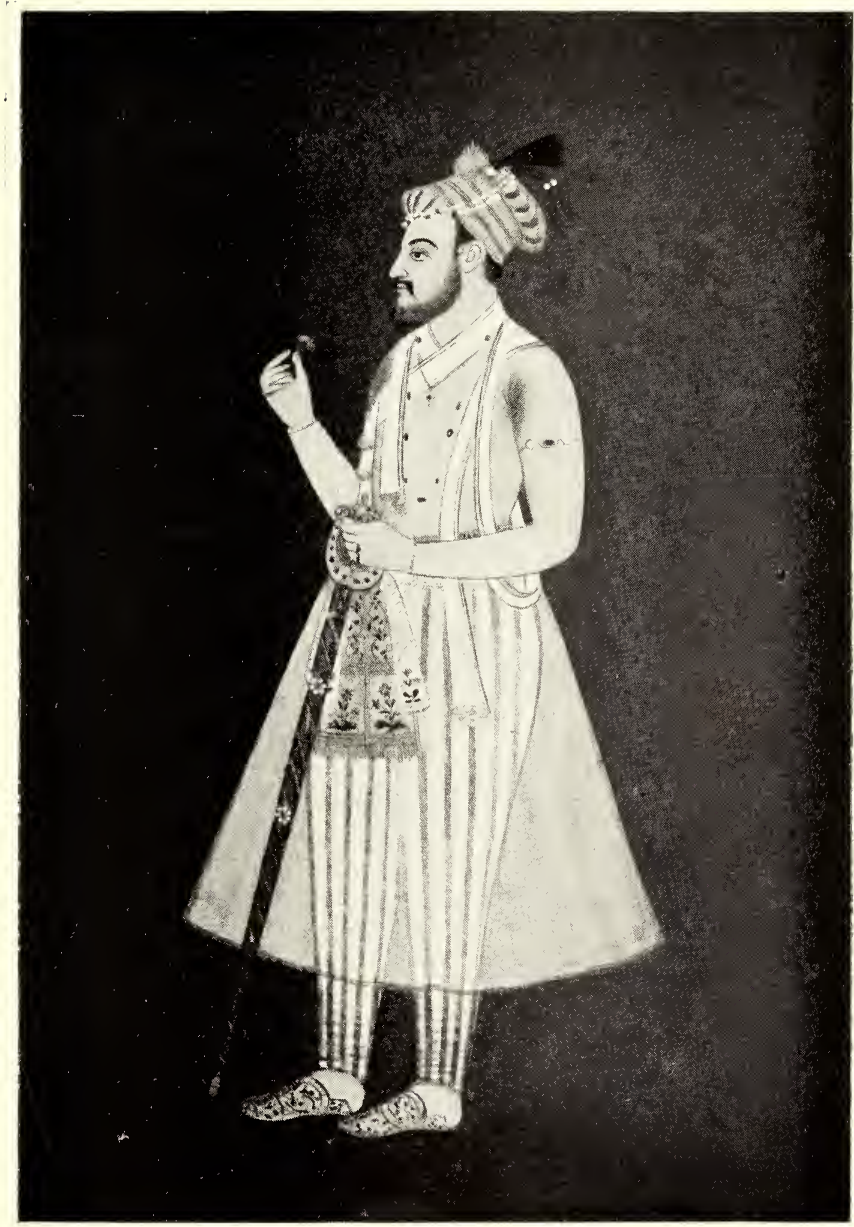

Portrait of Inuman Noble.

Rajput School.

India. XVIIIth Century.

See Item No. 210a. 


\section{Plate LXXXVIII.}

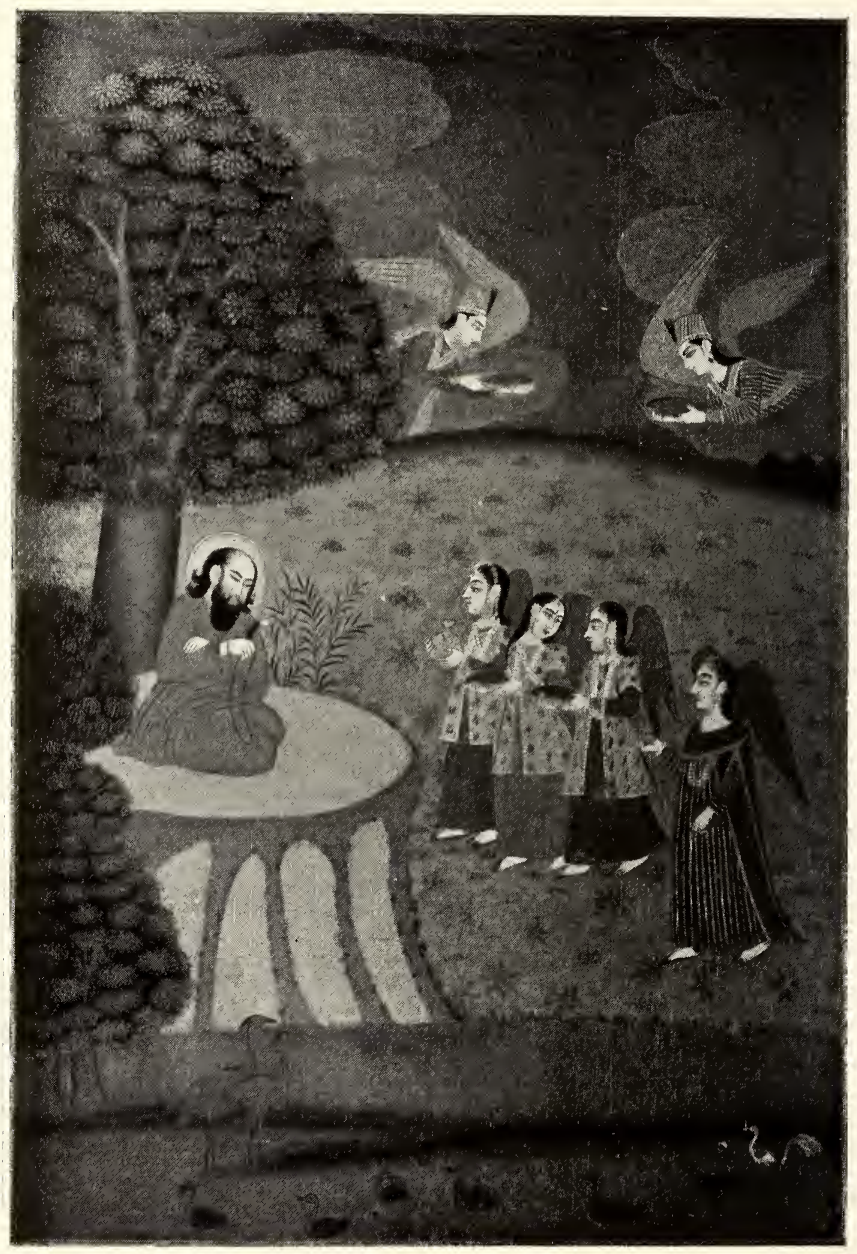

Ibrahim Edhem.

Rajput School.

India. XVIIIth Century.

See Item No. 216a. 
Indian (Rajput School)—continued.

2I6a IBRAHIM EDHEM. PORTRAIT' EXECU'TED IN GOLD AND COLOURS OF IBRAHIM EDHEM, A HOLY RECLUSE, SEATED UNDER A TREE, HOLDING A ROSARY, AND BEFORE HIM FOUR ANGELS WITH DISHES TO MINISTER TO HIS WANTS, WHILE TWO OTHER ANGELS ARE FLYING OVER A HILL TOP IN THE BACKGROUND; IN THE FOREGROUND DUCKS AND WADING BIRDS. ON THE BACK A HALF-PAGE SPECIMEN OF CALIGRAPHY.

Rajput School.

(MEASURING $9_{4}^{3}$ by $6 \frac{1}{2}$ INCHES).

(India. XVIIIth Century).

(See Illustration, Plate No. LxyyViII.).

$£ 1414 \mathrm{~s}$

\section{I7 MIYANI RAJINI OF KHARPUR.}

A PORTRAIT EXECUTED IN GOLD AND COLOURS OF MIYANI RAJINI OF KHARPUR, IN YELLOW DRESS, WEARING A HEADDRESS OF GREY ORNAMENTED WITH GOLD, HOLDING A FLOWER IN HER LEFT HAND, IN THE FOREGROUND ARE SMALL PINK AND RED FLOWERS.

Rajput School.

(MEASURING $7 \frac{1}{2}$ by $5 \frac{1}{\frac{1}{t}}$ INCHES).

(India. XVIIIth Century).

$\$ 665$

2 I 8 AKBAR SHAH.

A PORTRAIT EXECU'TED IN GOLD AND COLOURS OF AKBAR SHAH IN WHITE DRESS, TRIMMED WITH GOLD, WEARING A FINE TURBAN, LEANING ON HIS SWORD.

Rajput School.

(MEASURING Io by $6 \frac{1}{2}$ INCHES).

(India. XVIIIth Century). 
I98 MAGGS BROS., 34 \& 35, Conduit Street, London, W.

Indian (Rajput School)-continued.

2I 8 a INDIAN LADY IN A COSTUME OF RED AND GREEN RICHLY DECORATED WITH JEWELLERY, STANDING BETWEEN THREE MAGNIFICENT PEACOCKS. THE MINIATURE IS WITHIN DELIGHTFULLY DAINTY DOUBLE BORDERS OF BIRDS, FLOWERS AND BUTTERFLIES, MARIGOLDS, PINKS, ANEMONES, ROSES, NARCISSI, APPLE-BLOSSOM. IN ADDITION THERE IS AN INNER BORDER OF BLUE AND GOLD FLORAL ORNAMENTS.

Rajput School.

(MEASURING i 6 by i I INCHES).

(India. XVIIIth Century.)

(See Illustration, Plate No. LXXXiX.).

$£ 21$

\section{I9 SHAH SIKANDAR.}

A PORTRAIT EXECUTED IN GOLD AND COLOURS OF SHAH SIKANDAR, DRESSED IN BLUE, WITH A VERY LARGE TURBAN, PIERCING A LION WITH HIS LANCE.

THE MINIATURE IS SURROUNDED BY A MAGNIFICEN'T BORDER PAIN'TED IN GOLD ON A DARK BLUE GROUND, SHOWING LILIES, BRANCHES, LEAVES, BIRDS, ETC.

Rajput School.

(MEASURING 8 by $5 \frac{3}{ \pm}$ INCHES).

(India. XVIIIth Century).

$£ 1010$ s

2iga THE TWo Lovers. A LADY WITH A GREEN HEADDRESS, WEARING ALL HER JEWELLRY, CROSSING A FLOODED RIVER IN ORDER TO MEET HER LOVER ON HORSEBACK, WHO IS WAITING FOR HER. STREAKS OF LIGHTNING ARE CUTTING THE BLACKNESS OF THE NIGHT. A FINE NIGHT-SCENE ILLUSTRATING THE SORATHI-RAGMALA.

Rajput School.

(MEASURING I I by $7 \frac{1}{2}$ INCHES).

(India. XVIIIth Century). 


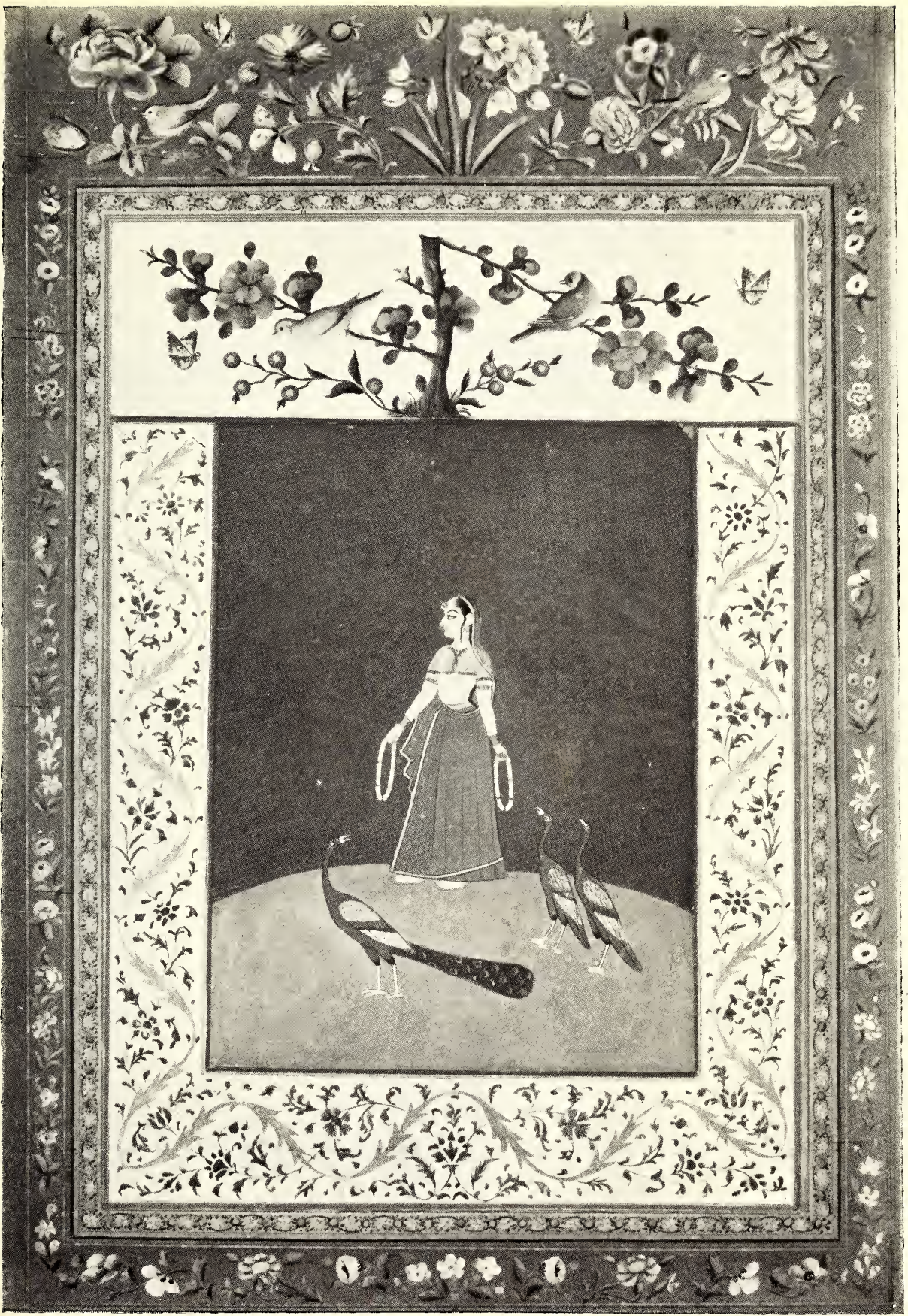

Tndan Lady and Peacocks. Rajput School.

India. XVIIIth Century. See Item No. 218a. 


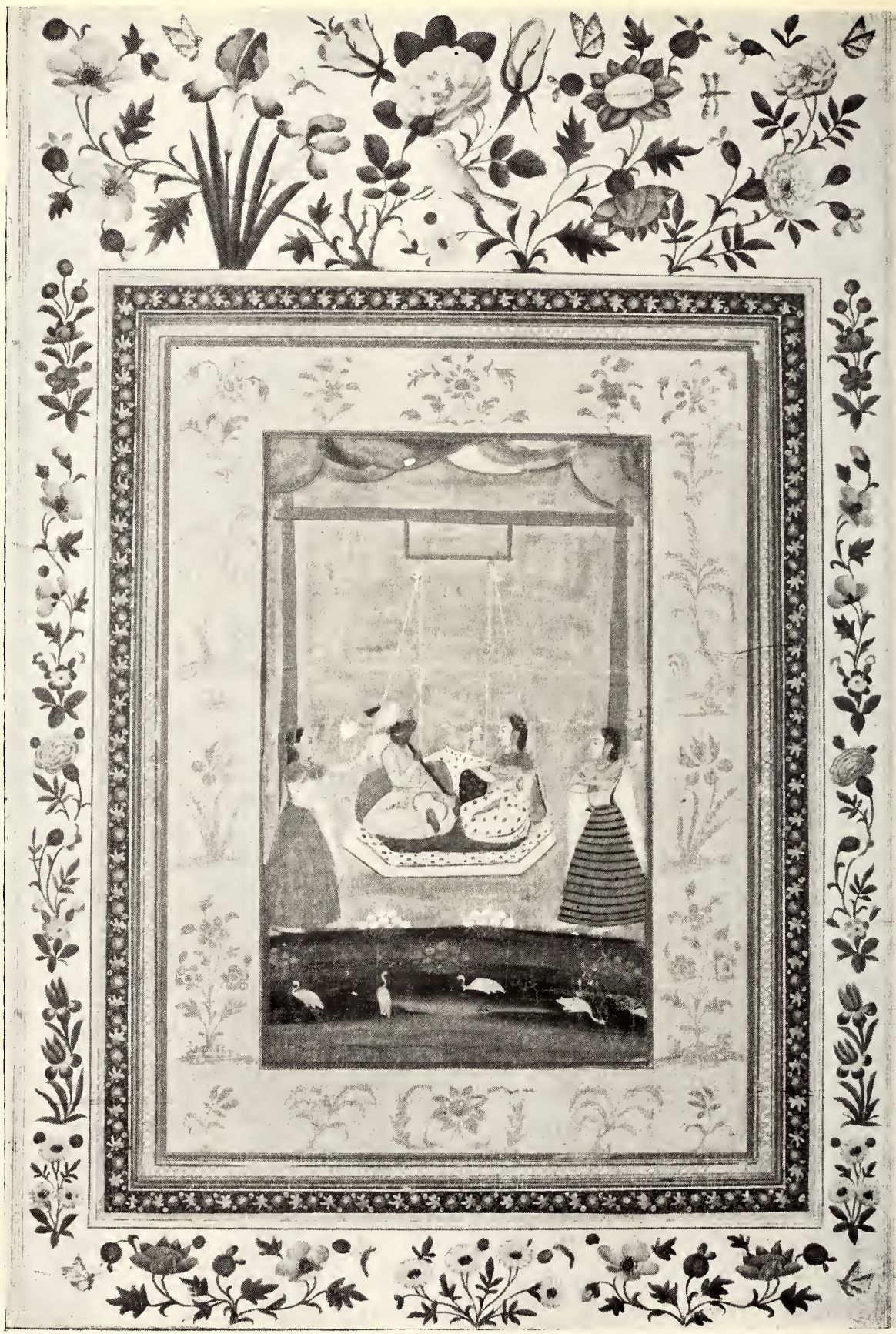

The Love-Swing.

Rajput School.

India. XVIIIth Century.

See Item No. 220. 
MAGGS BROS., 34 \& 35, Conduit Street, London, W.

Indian (Rajput School)-continued.

\section{THE LOVE-SWING.}

INDIAN LADY AND GEN'TLEMAN, SHE WITH A BLNCH OF FLOWERS IN HER RIGH'T HAND AND HE SMOKING A HOOKAH, SIT'TING IN A LOVE-SWING SUSPENDED FROM A RED BAMBOO FRAME. TWO AT'TENDAN'TS DRESSED IN HIGHLY COLOL'RED COSTUMES ARE PUSHING THEM TO AND FRO. IN THE FOREGROUND IS A POOL IN WHICH FOUR CRANES ARE STANDING. 'THE GROUND IS S'TUDDED WITH WILD FLOWERS, DAISIES, WHITE AND RED. WITHIN TRIPLE DELIGH'TFUL, DAINTY BORDERS OF BIRDS, BUTTERFLIES AND FLOWERS, MARIGOLDS, RED AND BLUE ANEMONES, IRIS, ROSES.

Rajput School.

(MEASURING i6 by i I INCHES).

(India. XVIIIth Century).

(See Illustration, Plate No. XC.).

f21

\section{AKBAR.}

A PORTRAIT EXECUTED IN GOLD AND COLOURS, OF THE, EMPEROR AKBAR, IN WHITE DRESS ORNAMENTED WITH GOLD, WEARING A TURBAN, SITTING ON A COUCH UNDER A GOLD' UMBRELLA, HIS HEAD ENCIRCLED BY A HALO.

Rajput School.

(MEASURING $8 \frac{3}{4}$ by $6 \frac{1}{2}$ INCHES).

(India. XVIIIth Century).

$£ 10$ 10s

\section{I THE EMPEROR SHAH JAHAN.}

A PORTRAIT EXECUTED IN GOLD AND CCLOURS OF THE EMPEROR SHAH JEHAN, IN WHITE AND GOLD DRESS. WEARING A 'TURBAN, RECLINING ON A COUCH ON A FINE CARPE'T, UNDER THE STATE UMBRELLA, HIS HEAD ENCIRCLED BY A HALO. IN THE BACKGROUND ARE FIVE A'T'TENDAN'TS, ALL AT'TIRED IN GAY COSTUMES.

Rajput School.

(MEASURING 9 by 7 INCHES).

(India. XVIIIth Century). 
Indian (Rajput School)_continued.

\section{ALAMGIR I.}

A PORTRAIT EXECUTED IN GOLD AND COLOURS OF ALAMGIR I., IN WHITE DRESS, WEARING A TURBAN, SIT'TING ON A CRIMSON AND GOLD COUCH, HOLDING A STRING OF BEADS IN HIS RIGH'T HAND, HIS HEAD IS ENCIRCLED BY A HALO. IN THE BACKGROUND ARE FOUR FLOWERING SHRUBS.

Rajput School.

(MEASURING $8 \frac{3}{4}$ by 6 INCHES).

(India. XVIIIth Century).

$£ 1212 s$.

\subsection{RAJA MADHU SINGH.}

A PORTRAIT EXECUTED IN GOLD AND COLOURS OF RAJA MADHU SINGH, IN RED DRESS, WEARING A FINE TURBAN, SI'TTING ON HIS FAMOUS SILVER THRONE SUPPORTED BY SILVER AND GOLD LIONS, HIS HEAD ENCIRCLED BY A HALO.

Rajput School.

(MEASURING $9 \frac{3}{4}$ by $6 \frac{1}{4}$ INCHES).

(India. XVIIIth Century).

$£ 10$ 10s

\section{JAHANGIR.}

A PORTRAIT EXECU'TED IN GOLD AND COLOURS OF EMPEROR JAHANGIR, IN PALE PINK AND WHITE DRESS TRIMMED WITH GOLD, WEARING A TURBAN, LEANING ON HIS SWORD. HIS HEAD ENCIRCLED BY A HALO.

Rajput School.

(MEASURING $8 \frac{1}{2}$ by 6 INCHES).

(India. XVIIIth Century).

£8 8s

225 MIYANI RAJINI OF KHARPUR.

A PORTRAIT" EXECU'TED IN GOLD AND COLOURS OF MIYANI RAJINI OF KHARPUR, IN ROSE PINK DRESS, WITH HEAD-DRESS OF PINK AND GOLD, HOLDING A FLOWER IN HER LEFT HAND. IN THE FOREGROUND ARE SMALL RED AND PINK FLOWERS.

Rajput School.

(MEASURING $8 \frac{1}{8}$ by $5 \frac{5}{8}$ INCHES).

(India. XVIIIth Century).

f. $10 \mathrm{~s}$ 
Indian (Rajput School)—continued.

\section{NAWAB TUHAF KHAN.}

A PORTRAIT EXECUTED IN GOLD AND COLOURS OF NAWAB TUHAF KHAN, IN DARK BLUE DRESS ORNAMEN'TED WITH GOLD, WEARING A TURBAN.

Rajput School.

(MEASURING IO $\frac{1}{2}$ by 7 INCHES).

(India. XVIIIth Century).

$f .6 \mathrm{~s}$

\section{RAJA BAKHT-SING OF JODHPUR.}

A PORTRAIT EXECUTED IN GOLD AND COLOURS OF RATA BAKH'T-SING OF JODHPUR, IN WHITE DRESS, WEARING A FINE TURBAN, A SWORD AT HIS SIDE, HIS HEAD ENCIRCLED BY A HALO.

Rajput School.

(MEASURING $9 \frac{3}{4}$ by $6 \frac{1}{2}$ INCHES).

(India. XVIIIth Century).

$£ 55 s$

228 PARTAB SING, RULER OF JODHPUR.

A PORTRAIT EXECUTED IN GOLD AND COLOURS OF PARTAB SING, RULER OF JODHPUR, DRESSED IN RED, KNEELING ON A CUSHION, WEARING A FINE TURBAN, HOLDING A STRING OF BEADS IN HIS RIGHT HAND, BEHIND HIM ARE TWO A'TTENDANTS, ONE HOLDING A FAN AND THE O'THER A FLY-SWITCH.

Rajput School.

(MEASURING I I by $7 \frac{1}{2}$ INCHES).

(India. XVIIIth Century).

£6 6s

\section{ALAMGIR II.}

A PORTRAIT EXECUTED IN GOLD AND COLOURS OF ALAMGIR II., IN WHITE DRESS, WEARING A SPLENDID TURBAN, HIS HEAD ENCIRCLED BY A HALLO, HOLDING A FLOWER IN HIS LEFT HAND, LEANING ON HIS SWORD.

Rajput School.

(MEASURING IO $\frac{1}{8}$ by $6 \frac{1}{2}$ INCHES.

(India. XVIIIth Century). 
Indian (Rajput School)-continued.

2.30 RANI JANI ASHUA. (Shuja' ab ud Dowla.)

A POR'TRAIT EXECUTED IN GOLD AND COLOURS OF RANI TANI ASHUA, IN WHI'TE DRESS, HOLDING IN HER HANDS A BUNCH OF NARCISSI, THE TIPS OF HER FINGERS ARE DYED WITH HENNA.

Rajput School.

(MEASURING $8 \frac{3}{4}$ by $5 \frac{1}{2}$ INCHES).

(India. XVIIIth Century).

$£ 66 s$

\section{I RAJNI MAHOMED SHAH WALI.}

A POR'TRAI'T EXECUTED IN GOLD AND COLOURS OF RAJNI MAHOMED SHAH WALI, DRESSED IN YELLOW AND GREEN, SITTING ON A RED CUSHION, SMOKING A HOOKAH.

Rajput School.

(MEASURING $7 \frac{1}{8}$ by 5 INCHES).

(India. NVIIIth Century).

$£ 5$ ss

\subsection{RAJAH GANGA OF BIKANIR.}

A POR'TRAIT EXECU'TED IN GOLD AND COLOURS OF RAJAH GANGA OF BIKANIR, IN WHITE DRESS, WITH SHIELD AND SWORD, WEARING A FINE TURBAN.

Rajput School.

(MEASURING Io $\frac{\bar{s}}{8}$ by $6 \frac{\pi}{8}$ INCHES).

(India. XVIIIth Century).

$£ 5$ 5s

\section{RANA AISI OF ODEPUR.}

A PORTRAI'T EXECU'TED IN GOLD AND COLOURS OF RANA AISI OF ODEPUR, IN YELLOW DRESS, TRIMMED WITH RED, WEARING A GORGEOUS TURBAN. HOLDING A FLOWER IN HIS LEFT HAND, AND LEANING ON HIS SWORD.

Rajput School.

(MEASURING IO $\frac{1}{2}$ by $7 \frac{3}{4}$ INCHES).

(India. XVIIIth Century). 
Indian (Rajput School)—continued.

\section{MAHARAJA RATAN SINGH OF BIKANIR.}

A PORTRAT'T EXECU'TED IN GOLD AND COLOURS OF THE MAHARAJA IN WHITE DRESS AND GORGEOUS TURBAN, ST'ANDING ON 'I'HE MADRISA' BETWEEN PINK AND RED DAISIES.

Rajput School.

(MEASURING 9 by $6 \frac{1}{2}$ INCHES).

(India. I 826).

$£ 66 s$

235 KRISHNA AND RADHA SITTING BENEATH A TREE WHILE AN ATTENDANT IS BRINGING THEM FRUIT ON A GOLDEN DISH. MOUNTED IN A HANDSOME BORDER.

Rajput School.

(MEASURING 8 by 6 INCHES).

(India. Early XIXth Century).

$£ 1515 s$

236 THE FOURFACED DEITY, BEING WORSHIPPED, ON A MAGNIFICENT CARPET IN FRONT OF AN ELABORATELY DECORATED PAVILION IN A GARDEN, BRILLIANT FLOWERS COMPLETE THE CHARM OF THE SCENE. MAGNIFICENTLYY PAIN'TED IN GOLD AND COLOURS WIT'H SUPERB BORDER OF FLOWERS ON A GOLD BACKGROUND.

Rajput School.

(MEASURING I 5 by io INCHES.)

(India. Early XIXth Century).

$£ 15$ 15s

237 KRISHNA SITTING BY THE SIDE OF A BRICK WELL, AND SPORTING WITH THE LADIES WHO COME TO FETCH WATER, WITH GOLDEN JARS ON THEIR HEADS, ONE MAIDEN IS SHEWN FILLING HER JARS FROM THE WELL BY THE AID OF A MOST PRIMITIVE ME'THOD. IN FRON'T IS A SMALL POND ON WHICH LOTUS ARE GROWING. A HANDSOME TREE IS GROWING OVER THE WELL, IN THE DISTANCE IS A BROAD RIVER. HILLS, TREES, PALACE WALLS, OVER WHICH THE SUN IS SETTING. 'CHARMING MINIATURE HEIGH'TENED WI'TH GOLD.

Rajput School.

(MEASURING 12 by $9 \frac{1}{4}$ INCHES).

(India. Early XIXth Century).

$£ 15$ 15s 
Indian (Rajput School)_continued.

2.38 KRISHNA, A LOTUS IN EACH HAND, SITTING ON A COUCH, ON HIS RIGHT RADHA IS SITTING ON ANOTHER COUCH, CLAD IN A LIGHT GREEN SILK VEST AND DRESSED IN GOLD AND GREEN TROUSERS, IN FRON'T OF HIM IS HANUMAN, THE MONKEY-GOD WITH AN ATTENDANT. THE WHOLE SCENE TAKES PLACE ON A RAISED TERRACE SURROUNDED BY BEAUTIFUL FLOWERS AND TREES IN FRONT OF THE PALACE.

Rajput School.

(MEASURING $9 \frac{1}{2}$ by 7 INCHES). .

(India. Early XIXth Century.)

$£ 12$ 12s

239 A GAME OF BACKGAMMON.

BEAUTIFULLY PAINTED INDIAN MINIATURE SHOWING FIVE LADIES PLAYING A GAME OF BACKGAMMON A'T NIGH'T, IN 'THE GARDEN OF THE ZENANA, BY THE LIGHT OF TWO CANDLES.

Rajput School.

(MEASURING $9 \frac{1}{2}$ by $6 \frac{1}{2}$ INCHES).

(India. Early XIXth Century.)

$£ 1010$ s

240 A PENDANT OF TWO INDIAN MINIATURES SHEWING A PRINCE RECLINING ON HIS COUCH WITH A LADY. BEAUTIFULLY EXECUTED IN GOLD AND COLOURS.

Rajput School.

(MEASURING 5 by 3 INCHES).

(India. Early XIXth Century).

$£ 1010 \mathrm{~s}$

24I INDIAN HORNED DEMON LEADING A SYMBOLIC BULL, FORMED OF HUMAN FIGURES AND VARIOUS OTHER ANIMALS IN THE CURIOUS INDIAN FASHION.

Rajput School.

(MEASURING $8 \frac{3}{4}$ by $10 \frac{1}{2}$ INCHES).

(India. Early XIXth Century.) 


\section{PERSIAN.}

24Ia SPECIMEN OF PERSIAN CALLIGRAPHY, WITHIN GOLD ORNAMENTAL BORDER. (In translation.)

" The Dervishes possess a sword of power,

You should not despise their company.

Seek help from the Will of Dervishes, for

The Dervish protects the safety of the King."

(In smaller letters.)

"Whoever confronts the lion and the tiger

Ought to beware of the sword of Dervishiem,

The hearts of these are like Files

If they do not cut themselves they straighten

(and subdue) those that cut."

(MEASURING $5 \frac{5}{8}$ by $9 \frac{1}{8}$ INCHES.)

(Persia. XVIIth Century).

$£ 212 s$ 6d

24Ib SPECIMEN OF PERSIAN CALLIGRAPHY, WITHIN GOLD ORNAMENTAL BORDER. (In translation.)

"Pir Hirst, may God sanctify his secret, says;

O God, do not extinguish this lighted lamp, and do not burn this afflicted heart, and do not tear his sewn curtain, and do not drive away this trained slave.

Peace and honour."'

(MEASURING 7 by $8 \frac{3}{4}$ INCHES.)

(Persia. XVIIth Century).

$£ 212 s$ 6d

24IC SPECIMEN OF PERSIAN CALLIGRAPHY, WITHIN GOLD ORNAMENTAL BORDER.

(A PAR'T OF A CER'TIFICA'TE OF SUCCESSION, WRIT'TEN IN BEAU'TIFUL FLOURISHING CHARACT'ERS.) (In translation.)

"Peace on their inhabitants!

As the chosen one of excellence. the great master Ala ul-Mlilat has returned the trust of Life to the demander Death (and died) and as his eldest son Mirza Hashim is in every way worthy of his father, therefore he is nominated as his successor in all the protected dominions generally and in Meshhed particularly.' (MEASURING $6 \frac{3}{4}$ by Io INCHES.)

(Persia. XVIIth Century). 


\section{Persian-continued.}

\section{MOHAMMED ALI THE PAINTER.}

PORTRAIT DELICATELY DRAWN IN PEN AND INK AND HEIGHTENED IN COLOURS AND GOLD OF MOHAMMED ALI, THE PAINTER, OF ISPAHAN, BY MANSUR.

THIS IS A PORTRAIT' OF THE FAMOUS PAINTER MIR MOHAMMED ALI, OF TABRIS, WHO WAS A SON IN LAW OF MIR AMID, AND FLOURISHED ABOUT I640. HE WAS A PAINTER OF THE SCHOOL OF ISPAHAN, AND A SIMILAR PORTRAIT DRAWING OF HIM IS NOW IN THE LEIPZIG MUSEUM OF APPLIED ART, AND WAS REPRODUCED BY DR. SCHULZ, IN HIS “ HISTORY OF PERSIAN PAINTING" (Leipzig, I9I4), plate i 7 I.

(MEASURING 6 by $3 \frac{1}{4}$ INCHES).

(Ispahan, Persia. About I640).

(See Illustration, Plate No. XCi.).

$£ 150$

243 EIGHT PAGES OF DECORATION IN COLOUR; FROM A MANUSCRIPT MADE IN KHORASSAN AT BAKHERZ. THE MANUSCRIPT IS THE KHIDR KHANI BY KHOSRAN DELHEVI, COPIED BY MOHAMED EL KATIB.

THE BORDERS OF THESE EIGHT PAGES REPRESENT SCENES OF PASTORAL LIFE, OR DIFFERENT WILD ANIMALS, A LION DEVOURING AN ANTELOPE AND ORNAMENTAL DECORATION. PERSIAN.

(MEASURING $1 \mathrm{O}_{2}^{\frac{1}{2}}$ by $6 \frac{1}{2}$ INCHES).

(Persia. Late XVIIIth Century). 
Plate XCI.

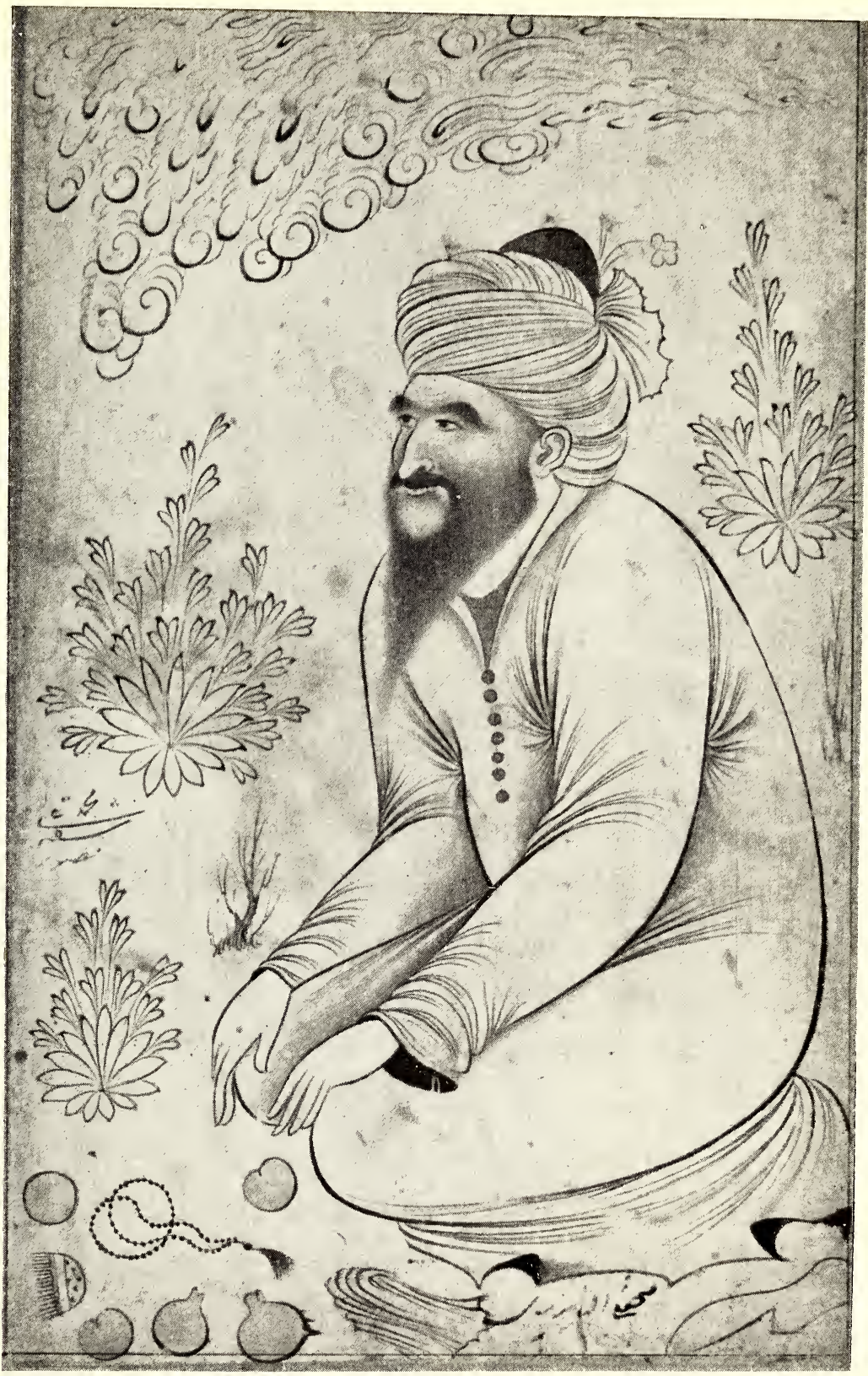

Portrait Drawing of Mohammed Alit the Painter. By Mansur. Ispahan, Persia. About A.D. 1640.

See Item No. 242. 


\section{Plate XCII.}

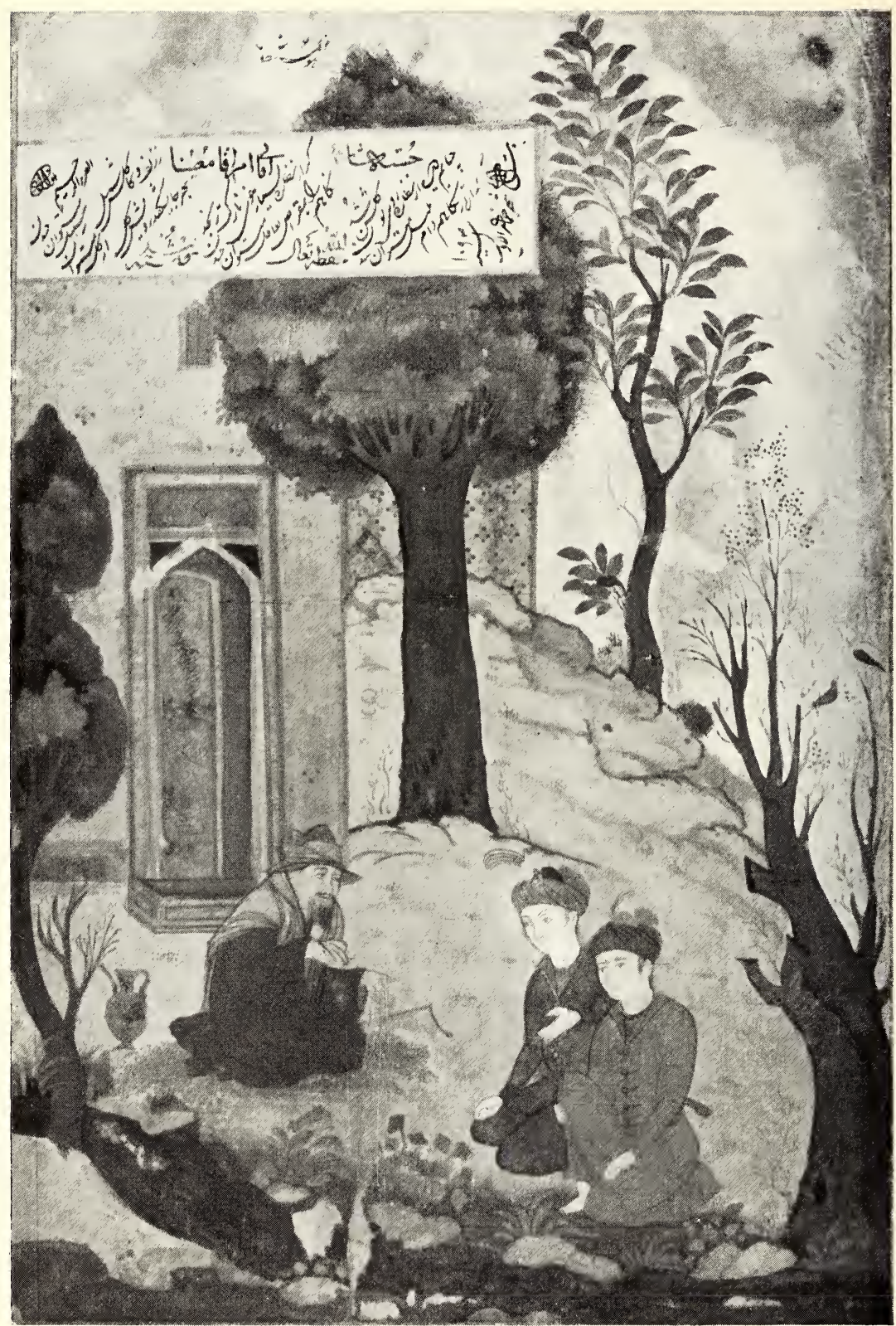

A Persias Mendicant.

Miniature in gold and colours by Mansur.

Persia. Dated A.D. 1682.

See Item No. 244. 
Persian-continued.

244 A PERSIAN MENDICANT.

PERSIAN MINIATURE BY MANSUR IN DELICATE COLOURS AND GOLD. A SCENE IN FRON'T OF A MOSQUE. A PERSIAN MENDICAN'I' TELLING THE BEADS OF HIS ROSARY, BY HIS SIDE ARE TWO ELEGAN'TLY DRESSED YOUNG MEN ADMIRING A STREAM ALONG THE BANKS OF WHICH ARE GROWING PINK AND WHITE FLOWERS, AND TWO TREES ON THE BRANCHES OF WHICH BIRDS ARE SITTING. IN THE BACKGROUND ARE FURTHER TREES AND A HILL.

THE MINIA'TURE IS DA'TED A.D. I682.

Persian School.

(MEASURING $6 \frac{1}{2}$ by $4 \frac{1}{4}$ INCHES).

(Persia. A.D. I682).

(See Illustration, Plate No. ICiI.).

$£ 5210 \mathrm{~s}$

\section{I DOUBLE MINIATURE.}

[I.] PERSIAN LADY BEFORE MAKING HER TOILE'T ON A TERRACE. [II.] A PERSIAN LADY RUNNING AFTER A WHITE CAT WHICH HAS SEIZED AND RUN AWAY WITH A GREEN PARROT. WITHIN DAIN'TY DOUBLE BORDERS OF BIRDS, BUT'TERFLIES AND FLOWERS, WILD ROSES, PEACH-BLOSSOMS, NARCISSI, FRENCH MARIGOLDS, LILIES, POPPIES, AT BO'TTOM A CHARMING VARIEGATION OF ROSES AND GREEN, BLUE AND FLORAL ORNAMENTS.

(MEASURING i6 by I I INCHES).

(Persia. XVIIth Century).

$£ 1616 s$

252 PORTRAIT OF AN AGED MAN, SUFI SHEIK ABUSAID ABUL KHAIR, WEARING AN UNDER-GARMEN'T OF BRIGH'T ORANGE COVERED WITH A BLUE CLOAK LINED WI'TH YELLOW. HE IS SITTING IN THE MIDST OF A LANDSCAPE ON A FINE ORIENTAL CARPET, ABOU'T TO DRINK. AT BACK DELICATE TREES AND SHRUBS AND BLUE SKY.

Persian.

(MEASURING 6 by 4 INCHES).

(Persia. XVIIth Century).

$£ 1616 \mathrm{~s}$ 
2 I2 MAGGS BROS., 34 \& 35, Conduit Street, London, W.

\section{Persian-continued.}

\section{2a PERSiAn DRAWING.}

DRAWING OF A YOUTH WEARING AN ELABORATELY EMBROIDERED COAT AND SKIR'T, A GILT DAGGER STUCK IN HIS COAT, HOLDING A WINE CUP IN HIS RIGHT HAND AND A WINE FLASK IN HIS LEFT. ON HIS HEAD A WHITE AND BLUE TURBAN. IN THE FOREGROUND AND BACKGROUND ARE ROCKS AND TREES. THE DRAWING IS DELICATELY TINTED, AND HEIGHTENED WITH GOLD.

\section{SIGNED RIZA-I-ABBASI.}

(MEASURING 6 by 4 INCHES).

(Persia. About I64.0).

(See Illustration, Plate No. XCiII.).

$£ 75$

\section{2b CALLIGRAPHY.}

SPECIMEN OF PERSIAN CALLIGRAPHY, ELEGANT SHIKAST, WITH DELIGH'TFULLY EXECUTED DAINTY DOUBLE BORDERS, OF BIRDS AND FLOWERS, INDIAN PINKS, ANEMONES, NARCISSI, FRENCH MARIGOLDS, HYACINTHS, MARIGOLDS, HAZELNUTS, DOUBLE NARCISSI.

(MEASURING I 6 by i INCHES.)

(Persia. XVIIth Century.)

$£ 44 s$.

\section{C CALLIGRAPHY.}

ARABIC TEXT. SPECIMEN OF ORNAMENTAL WRITING. BEAUTIFULLY WRI'TEN IN ARABIC, IN GOLD LETTERS ON A TURQUOISE BLUE BACKGROUND.

(MEASURING I 6 by I I INCHES.)

(Persia. XVIIIth Century.) 
Plate XCIII.

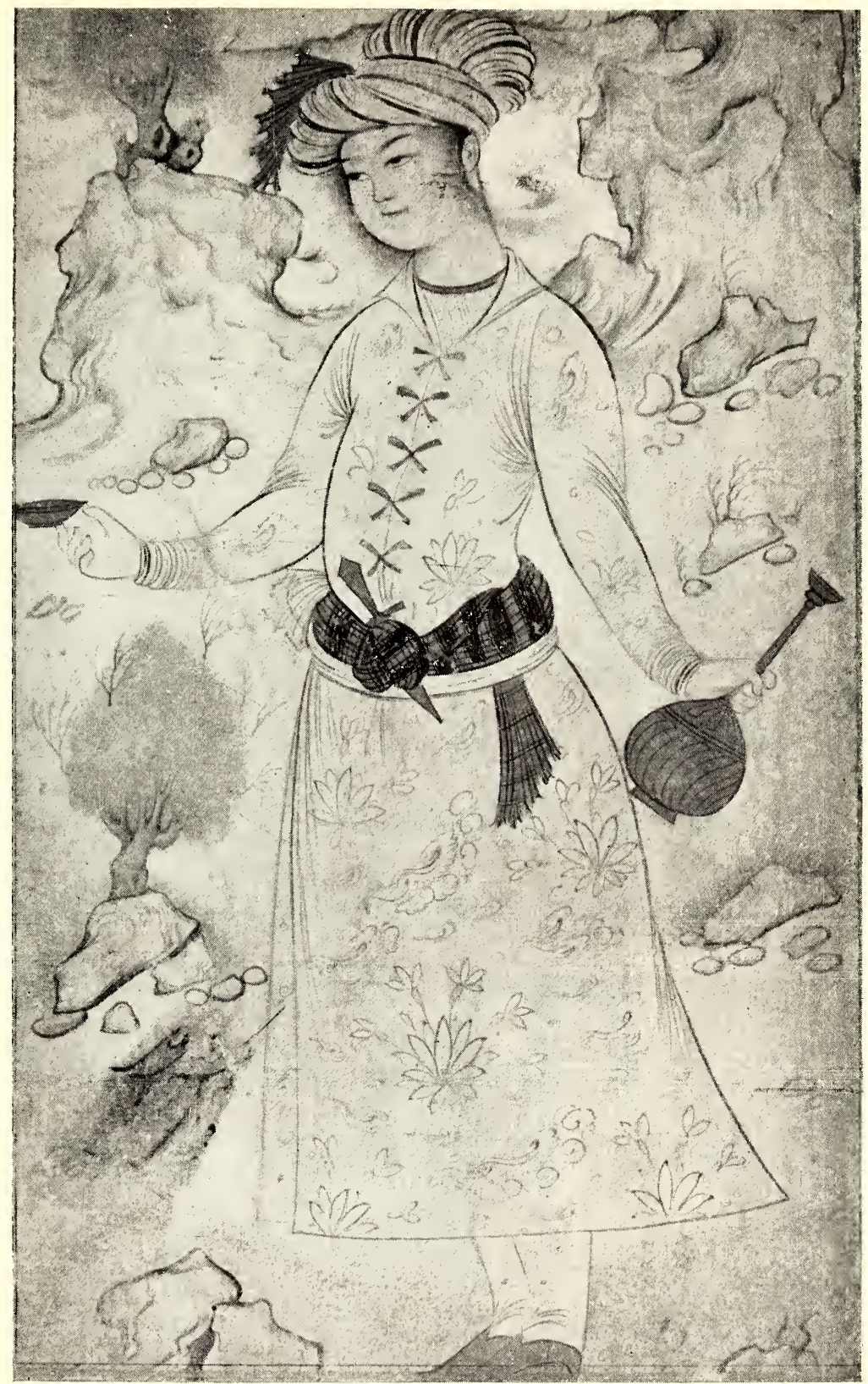

Persian Drawing of a Yoeth, signed Rizi I-Abbasi.

Persia. About A.D. 1640.

See Item Yo. 252A. 


\section{Plate XCIV.}

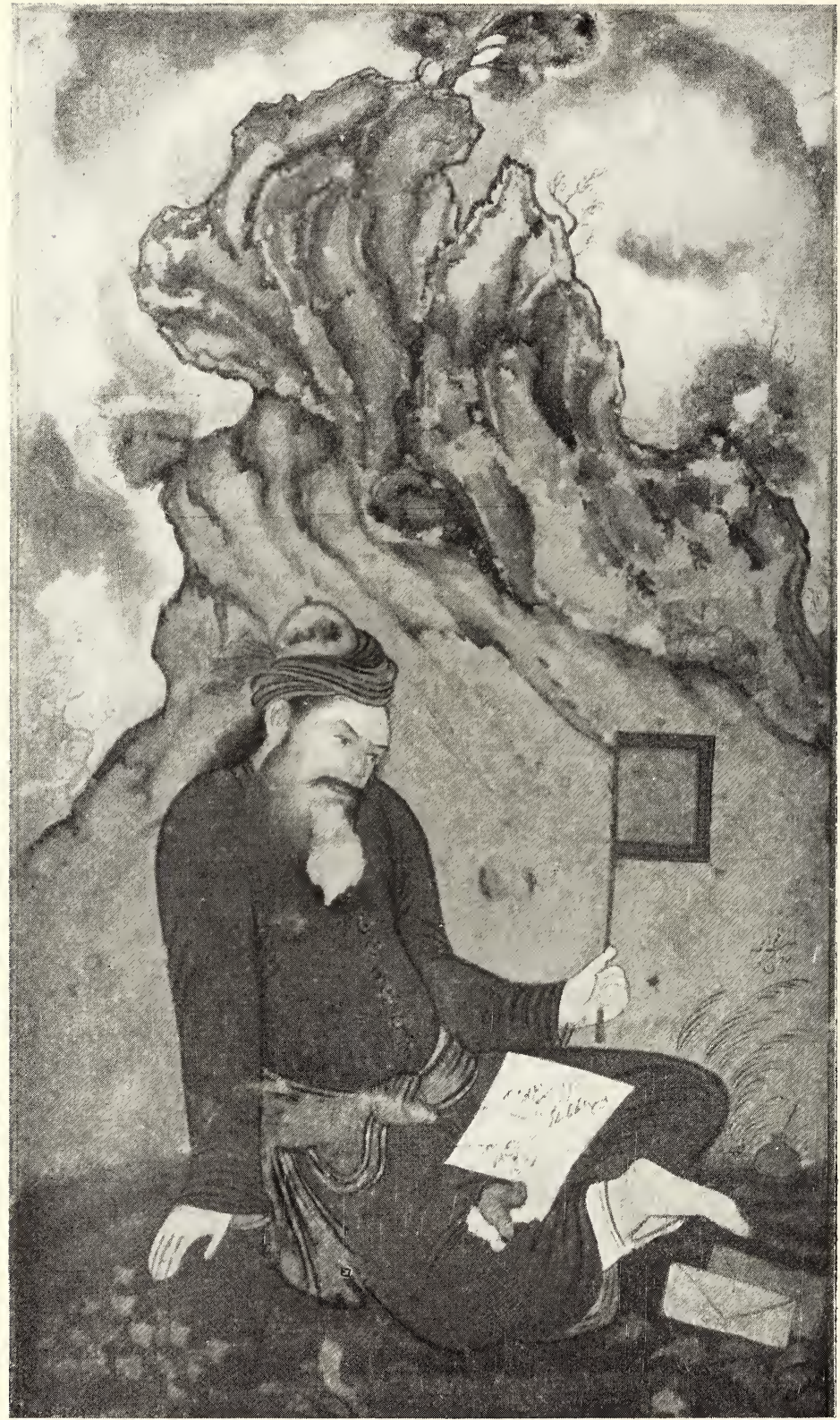

Portrait of a Persian by Mansur. Persia. About A.D. 1640.

See Item No. 253. 
Persian-continued.

253 PORTRAIt of a PERSIAN BY MANSUR BEARING A FLAG IN HIS LEFT HAND, A PURPLE BELT ROUND HIS WAIST, HE HAS JUS'T WRITTEN A LETTER. AT THE BACK IS A RUGGED ROCK WITH TREES, IN THE FOREGROUND GRASS AND FLOWERS. A GOLDEN INK-POT AND A WRITING CASE ARE ON HIS RIGH'T. THE MINIATURE IS DELICATELY COLOURED AND HEIGHTENED WITH GOLD.

(MEASURING $6 \frac{1}{\ddagger}$ by $3 \frac{1}{2}$ INCHES).

(Persia. About i640).

(See Illustration, Plate No. XCiV.).

$£ 75$

253a SPECIMEN OF PERSian CALligraphy, WITHIN GOLD ORNAMENTAL BORDER. (In translation.)

"I shall dictate to you a word of wisdom,

Which deserves to be written with liquid gold,

It is better to eat your own poison

Than to lick another's honey from your fingers."

Written by

Abdulla.

"They say that Khakani does not give his heart (love) to men

I shail not sell my heart, which is the dog of the cave $\left({ }^{1}\right)$ to Bilam $\left({ }^{2}\right)$.

I shall not make orer the needle of Jesus to blind-hearted men (perverted).

I shall not sell the thread of Mary to the renders of our curtains (slanderers).

(MEASURING $4 \frac{7}{8}$ by $7 \frac{3}{8}$ INCHES.)

(Persia. XVIIth Century).

£3 3s

(1) Kutmir, the companions of the seven sleepers. It is one of the few animals which will go to paradise.

(2) The aged derotee of Moses' time who was condemned for his onceit of piety and hypocrisy. 


\section{Persian-continued.}

\section{TRIPLE MINIATURE.}

THREE MINIATURES, ONE SHCWING A PERSIAN LADY STAINING HER FEE'T WITH HENNAH. BETWEEN TWO ALMOND TREES IN FULL BLOSSOM. ON THE RIGH'T IS A NATIVE COUPLE ENGAGED IN TALKING AND ABOVE IS A PERSIAN GENTLEMAN CAROUSING WITH A COURTEZAN, A'T'TENDANTS ARE BRINGING THEM ROSES. WITHIN A DOUBLE DAINTY BORDER OF BIRDS AND FLOWERS, WALLFLOWERS. PINKS, MARIGOLDS, RED AND BLUE ANEMONES. VIOLETS, PEACH-BLOSSOM, INDIAN PINKS, IRIS, HAZEL-NU'TS, TULIPS, ROSES.

(MEASURING i 6 by I I INCHES).

(Persia. XVIIIth Century).

(See Illustration, Plate No. XCV.).

\section{$£ 1818 \mathrm{~s}$}

254a SPECIMEN OF PERSIAN CALLIGRAPHY, WITHIN GOLD ORNAMEN'TAL BORDER. (In translation.)

" May my head be sacrificed to thee when thy sword revolves round my head,

I have no heart left which should become a shield for thy arrow ! $\mathrm{Oh}$, do not be deceived by youth and ten days (i.e. short lived) beauty!

Because, even the Sun on reaching its zenith turns back (and declines)."

\section{Written by}

Mir Ali.

(MEASURING $5 \frac{3}{4}$ by $8 \frac{3}{4}$ INCHES.)

(Persia. XVIIth Century).

£3 3s

254b SPECIMEN OF PERSIAN CALLIGRAPHY, WITHIN GOLD ORNAMENTAL BORDER. (In translation.)

"If you want a jar full of silver, or a golden tray, You ought to pass into the land of Iraq.

May the hear inspiring (land of) Iraq be ever blesses;

For the fame of learning has increased on account of her."

(MEASURING $4 \frac{1}{2}$ by 7 INCHES.)

(Persia. XVIIth Century.) 

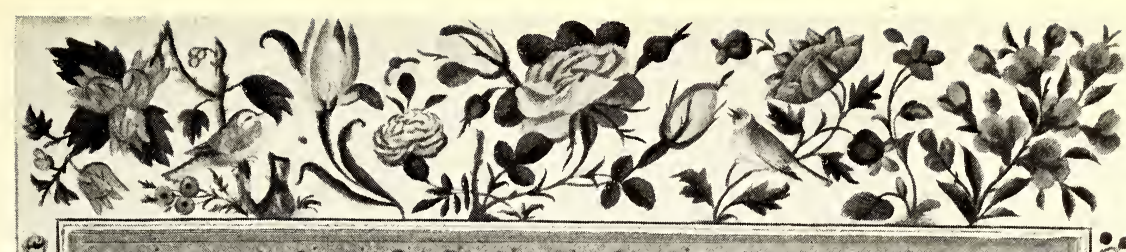

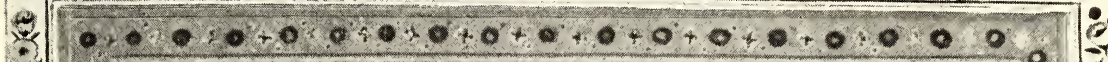

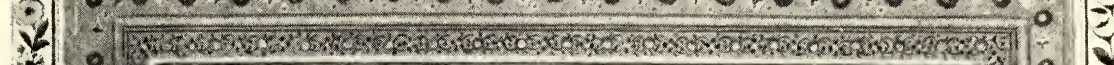

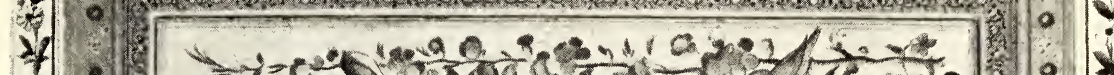

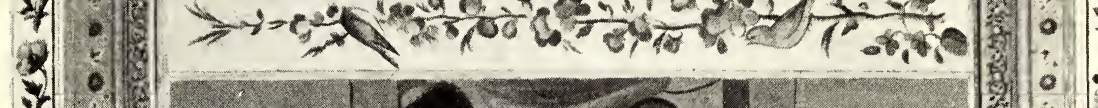

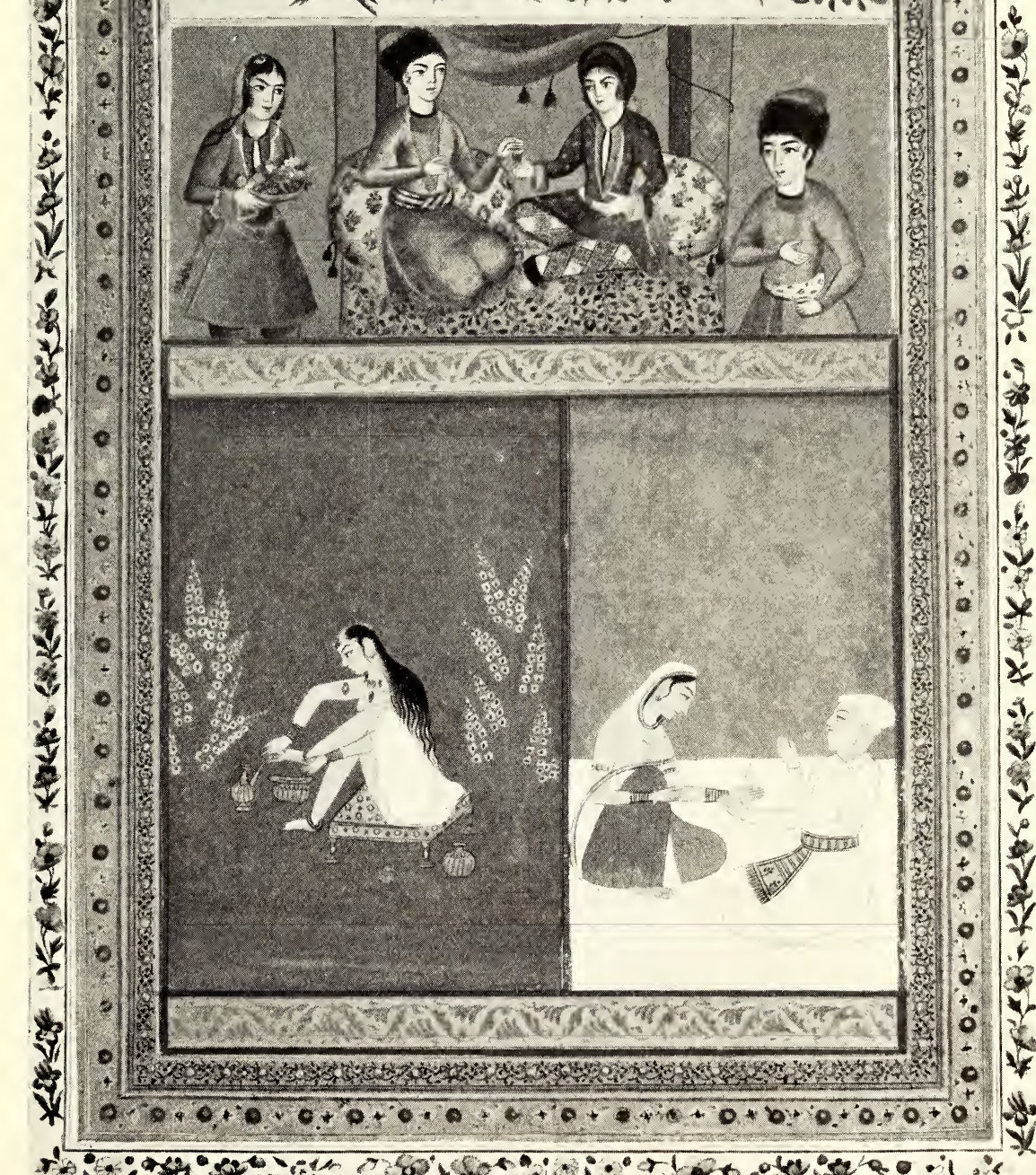

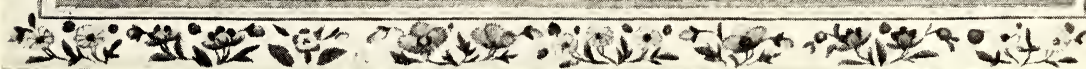

'Trifle Miniature.

Persia. XVIITth Century.

See Item No. 254. 


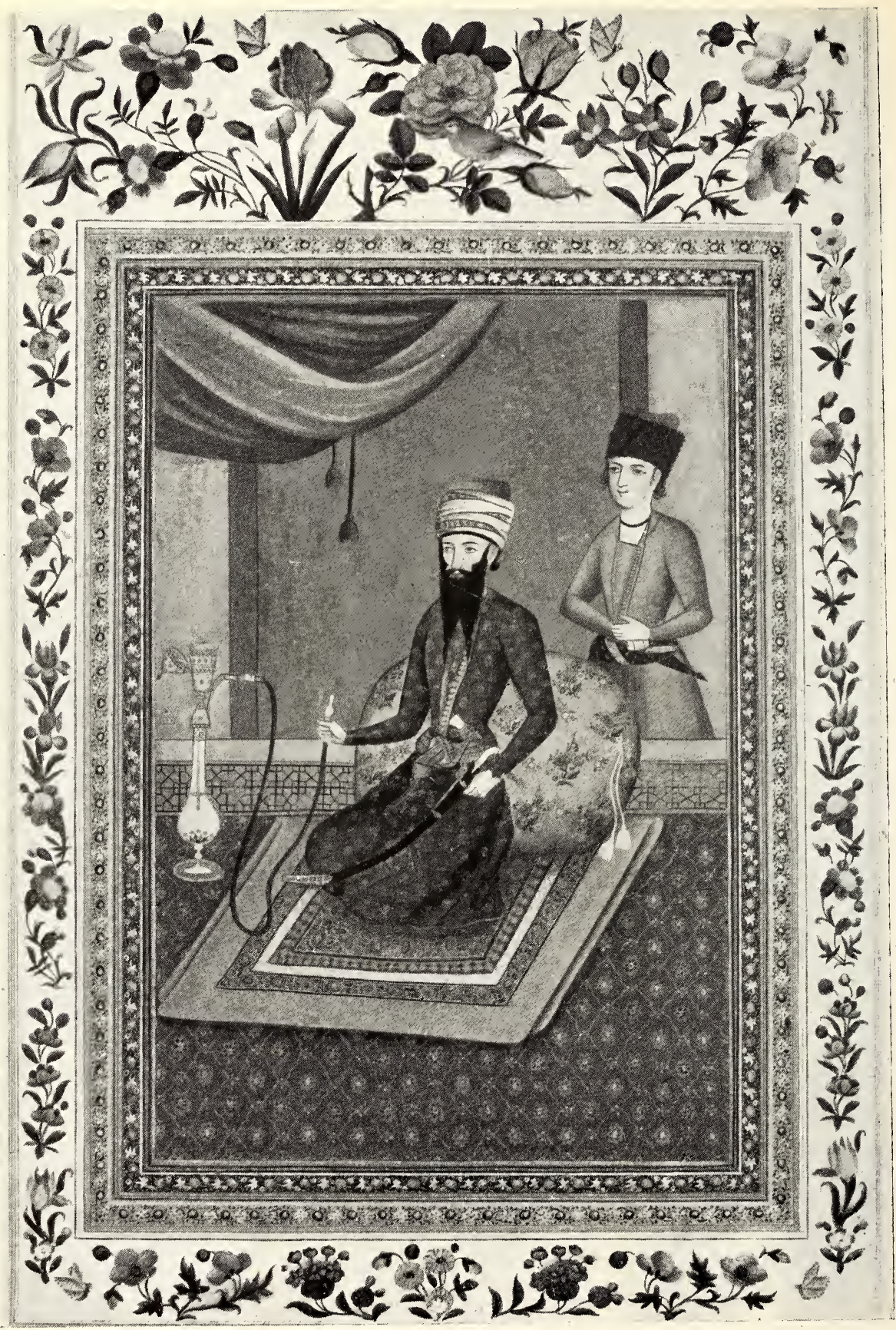

Portrait of Persiax Prince Shokixg a Hookah. Persia. XVIIIth Century. See Item No. 255. 
Persian-continued.

255 PORTRAIT OF A PERSIAN PRINCE SMOKING A HOOKAH, HE IS RICHLY ROBED IN AN EMBROIDERED GREEN DRESS ANL WEARS A LONG BLACK BEARD, HE IS RECLINING ON AN EMBROIDERED GOLD CUSHION. AN ATTENDAN'T IS ON HIS RIGH'T. WITHIN A DAIN'TY, DELIGHTFUL BORDER OF BIRDS, BU'TTERFLIES AND FLOWERS, MARIGOLDS, IRIS. POPPIES, ANEMONES, TULIPS, ROSES AND SOME O'THER ORIEN'TAL FLOWERS.

(MEASURING i6 by i I INCHES.)

(Persia. XVIIIth Century).

(See Illustration, Plate No. XCVi.).

$£ 1515 s$

$255 \mathrm{a}$ CALLIGRAPHY.

SPECIMEN OF PERSIAN CALLIGRAPHY BY MOHAMMAD EMIN IN VERSE, WITHIN DELIGH'TFULLY EXECU'TED DAIN'TY DOUBLE BORDERS, OF BIRDS AND FLOWERS, ROSES, JAPONICA, FUCHSIA, ANEMONE, POPPY, LILY, PANSY, PINK, VIOLET, MARIGOLDS, JASMINE, NARCISSUS, IRIS, CHERRY-BLOSSOM, APPLEBLOSSOM, ALMOND-BLOSSOM, HYACIN'THS, HAZEL NU'TS, BLACKBERRY-BLOSSOM.

(MEASURING i6 by i I INCHES.)

(Persia. XVIIth Century).

$£ 1212 s$

256 ABRAHAM ON MOUNT MORIAH ABOUT TO SACRIFICE ISAAC, THE ANGEL IS HOLDING BACK A SWORD AND POIN'TING TO THE RAM CAUGHT IN THE THICKE'T. WITHIN DAIN'TY DELIGH'TFUL BORDERS OF BIRDS, BUTTERFLIES AND FLOWERS, ROSES, IRIS, MARIGOLDS, ANEMONES, TULIPS, YELLOW IRIS.

(MEASURING i6 by i I INCHES.)

(Persia. XVIIIth Century).

$£ 1010 \mathrm{~s}$

\section{PORTRAIT OF A PERSIAN PRINCE.}

PERSIAN MINIATURE OF A YOUNG PERSIAN PRINCE DRESSED IN A COAT OF CLOTH OF GOLD, TRIMMED WITH FUR, A FUR CAP WITH A PURPLE FEATHER, BLACK LOVE-LOCKS, PINK AND GREEN BOO'TS AND A VIOLE'T WAIS'TCOAT AND SKIRT, WITH GOLD BU'T'TONS.

(MEASURING 8 by 4 INCHES.)

(Persia. XVIIth Century.) 


\section{Persian-continued.}

258 PORTRAIT OF A PERSIAN PRINGE DRESSED IN CLO'TH OF GOLD WITH PEARL BUTTONS, RECLINING ON A BRIGHTLY COLOURED CARPET OF RED, GREEN, BLUE AND GOLD, SAYING HIS PRAYERS WITH A ROSARY, HE HAS A LARGE MOUSTACHE AND A FINE TURBAN, AT HIS SIDE IS A SWORD AND BEHIND HIM HIS BOW AND ARROWS. BEHIND HIM IS AN ATTENDANT BRINGING HIM A CUP. WITHIN DELIGHTFUL BORDERS OF BIRDS, FLOWERS AND BUTTERFLIES, APPLE-BLOSSOMS, ROSES, ANEMONES, INDIAN PINKS, IRIS, PEACH-BLOSSOMS.

(MEASURING i6 by i I INCHES.)

(Persia. XVIIIth Century).

(See Illustration, Plate No. YCVII.).

$£ 15$ 15s

258 a A MONKEY ON A DRAGON, HOLDING A SHIELD AND BRANDISHING A CLEAVER. CAREFULLY DRAWN IN BLACK AND WHITE.

Shah Tahmasp School.

(MEASURING $3 \frac{1}{\frac{1}{4}}$ by $4 \frac{1}{2}$ INCHES.)

(Persia. XVIIIth Century.)

£1 $10 \mathrm{~s}$

CAREFULLY DRAWN IN BLACK AND WHI'TE.

Shah Tahmasp School.

(MEASURING $4 \frac{1}{8}$ by $5 \frac{1}{8}$ INCHES.)

(Persia. XVIIIth Century.) 
Plate XCVII.

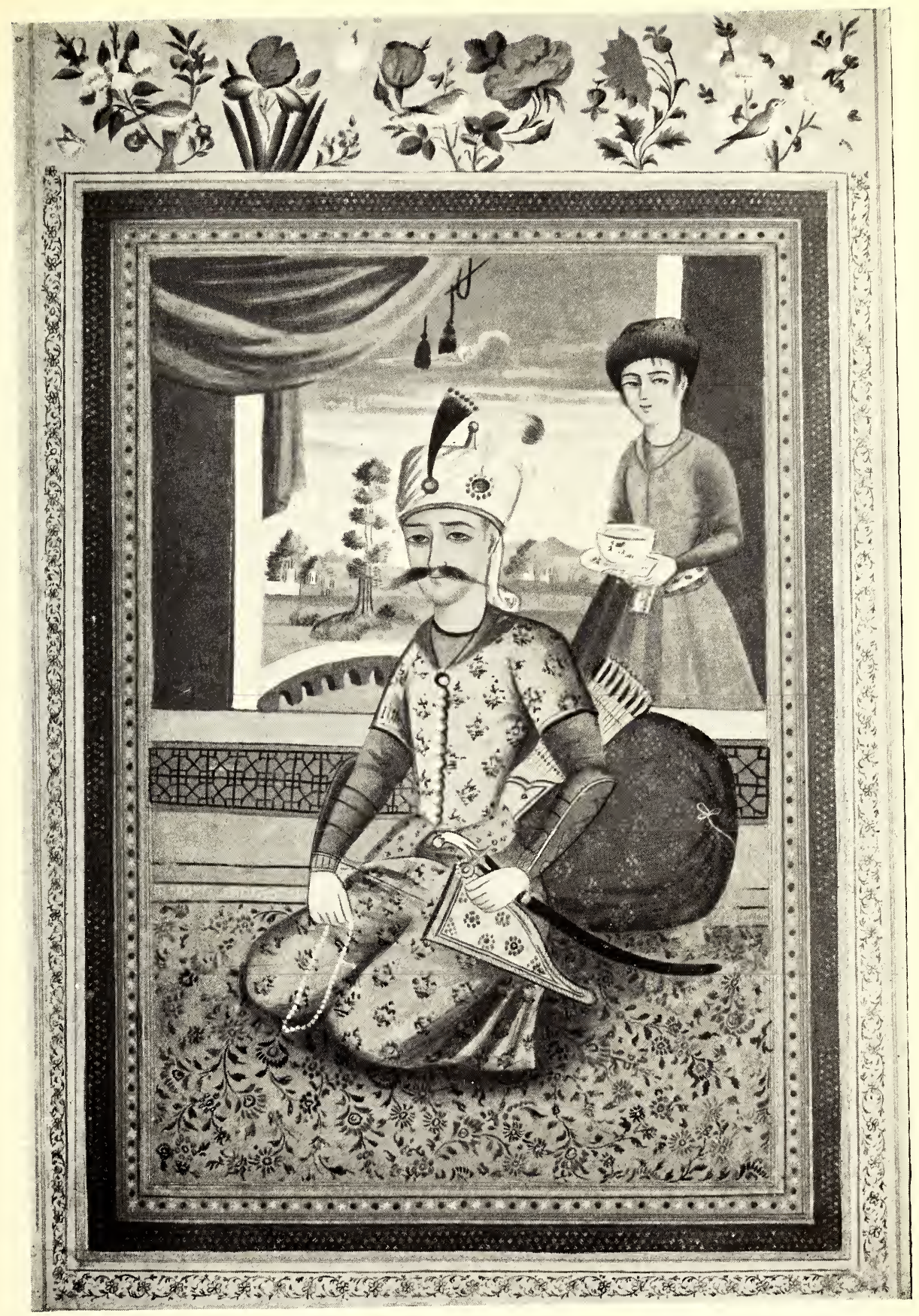

Portrait of Persian Prince.

Persia. XVIIIth Century.

See Item No. 258. 


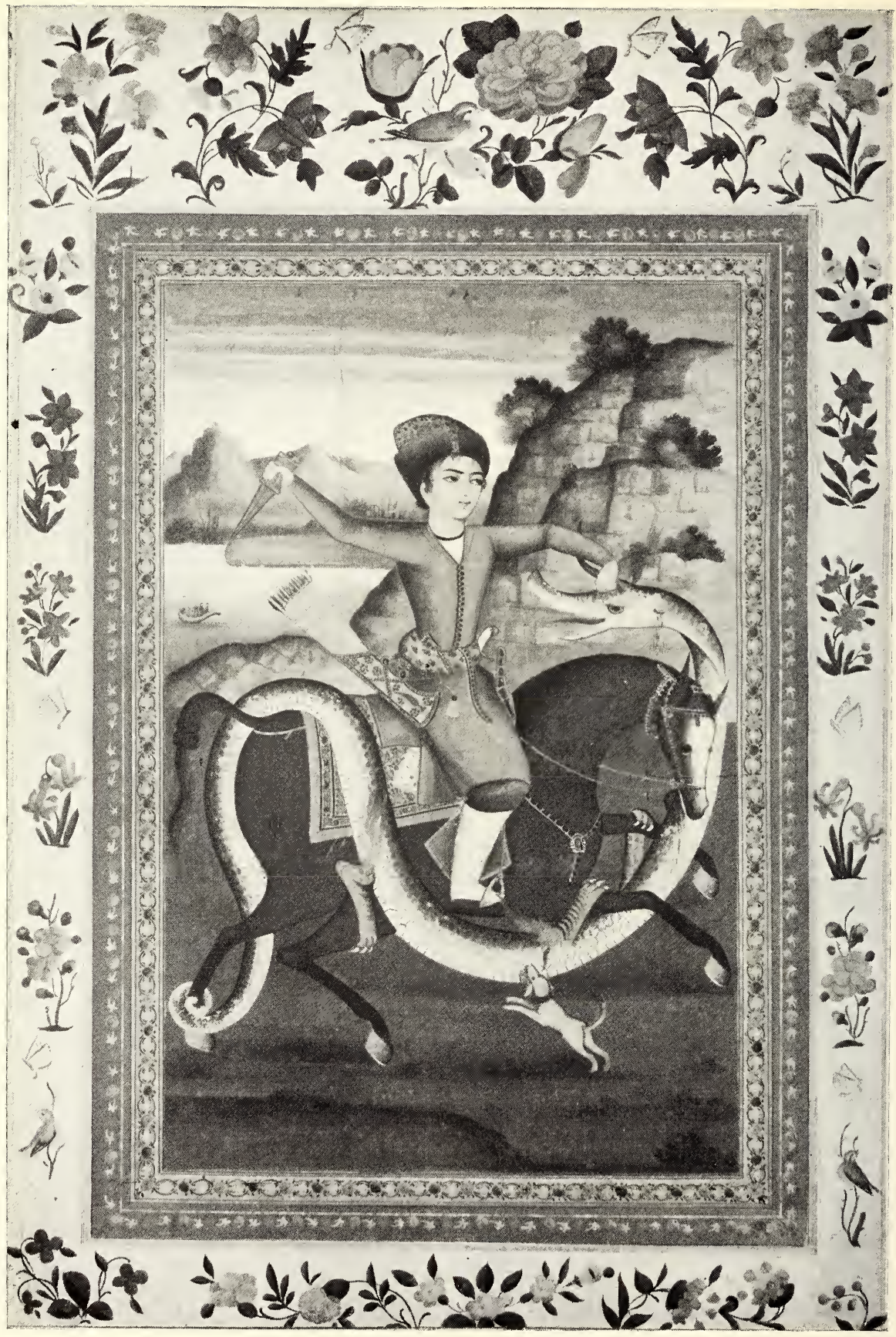

An Equerry of the Shah Abbas Bin.

Persia. XVIIIth Century.

See Item No. 260. 


\section{Persian-continued.}

\section{AN EQUERRY OF THE SHAH ABBAS BIN.}

A PORTRAIT EXECUTED IN GOLD AND COLOURS OF AN EQUERRY OF THE SHAH ABBAS BIN, DRESSED IN PINK, WEARING A TURBAN, HOLDING A DAGGER IN HIS RIGH'T HAND, MOUNTED ON A HORSE KILLING A DRAGON. HIS LITTLE DOG IS RUNNING BY THE SIDE OF THE HORSE. THE EQUERRY HAVING BEEN HUNTING AT HAZAR DERRE IN THE MOUNTAINS NEAR ISPAHAN, WAS ATTACKED BY A FRIGHTFUL DRAGON WHICH FLEW A'T HIS HORSE'S HEAD. THE YOUNG MAN DEFENDEI) HIMSELF FOR A FEW MINUTES WITH HIS HUNTING KNIFE, BUT AT LAST BOTH HIS STRENGTH AND THAT" OF THE HORSE GAVE WAY. HIS DOG, WHO WAS GREATLY ATTACHED TO THE HORSE, SEIZED THE DRAGON HIMSELF, AND AT A SIGNAL FROM HIS MASTER HE INFLICTED SEVERAL MORTAL WOUNDS. THE WHOLE WITHIN A DAINTY BORDER OF BIRDS, BUTTERFLIES AND FLOWERS, VIOLETS, ROSES, ANEMONES, MARIGOLDS, BLUEBELLS, AND OTHER DELICATELY TINTED BLOSSOMS.

(MEASURING $12 \frac{3}{t}$ by 9 INCHES).

(Persia. XVIIIth Century).

(See Illustration, Plate No. XCVili.).

$£ 1818 \mathrm{~s}$

26i SPECimen OF PERsian Calligraphy, WiTHin GOLD ORNAMENTAL BORDER. (In translation.)

" O my heart, the foot of the sky is still in the pitch ( $\left.{ }^{1}\right)$ Stand up and drink, for it is the time of night travelling; As yet, when the Dancing girl of the night $\left({ }^{2}\right)$ has turned only one or two of her hairs grey,

Take, (and quaff) the cup for one more hour and she will be old." (MEASURING $5 \frac{3}{8}$ by $8 \frac{3}{4}$ INCHES.)

(Persia. XVIIth Century).

£2 12s 6d

(1) i.e., It is still right, or you are still young.

(2) i.e., The Venus. 
Persian-continued.

262 A PORTRAIT, ELEM KAN KERMANI, A CELEBRATED PERSIAN COURTEZAN OF SHIRAZ, UNDER THE REIGN OF KERIM KAN, DRESSED IN PINK, WEARING TROUSERS OF A PECULIAR CHINESE PATTERN, RECLINING ON A GOLD CUSHION SPRIGGED WITH FLOWERS, BEING ENTER'TAINED BY TWO LADY MUSICIANS (ALSO WEARING TROUSERS). IN THE BACKGROUND ARE THREE A'TTENDANTS, ONE HOLDING A CHILD IN HER ARMS. IN THE FOREGROUND IS A TRAY ON WHICH DISHES OF FRUIT ARE PLACED, AND A CHILD PLAYING WITH TWO WHITE RABBITS. THE WHOLE WITHIN A DAINTY BORDER OF BIRDS, BUTTERFLIES AND FLOWERS, CARNATIONS, PINKS, MARIGOLDS, ANEMONES, TULIPS AND PEACH-BLOSSOM.

(MEASURING I $2 \frac{3}{4}$ by $9 \frac{1}{4}$ INCHES).

(Persia. XVIIIth Century).

(See Illustration, Plate No. XCIX.).

$£ 21$

263 SPECIMEN OF PERSIAN CALLIGRAPHY, WITHIN GOLD ORNAMEN'TAL BORDER. (In translation.)

" O true believers, $\mathrm{O}$ true believers, true belief, true belief; Repent of this worldly mindedness, repent.

How free are the poor from the harm of responsibilities!

How needy are Kings of the materials of greatness!

After forty years this fact is revealed to Khakani

That poverty is (real) sovereignty, and sovereignty (real) poverty! The rawhide garment which is covering my ripe heart (is so precious to me that)

I shall not sell a piece of it for a thousand pieces of painted silk.

This one nights privacy which I have in a week

I shall not sell it for six absolute days.

You said why I do not serve the King?

I shall not sell a moments freedom for the two worlds! " (MEASURING $5 \frac{1}{2}$ by $9 \frac{3}{4}$ INCHES.)

(Persia. XVIIth Century). 


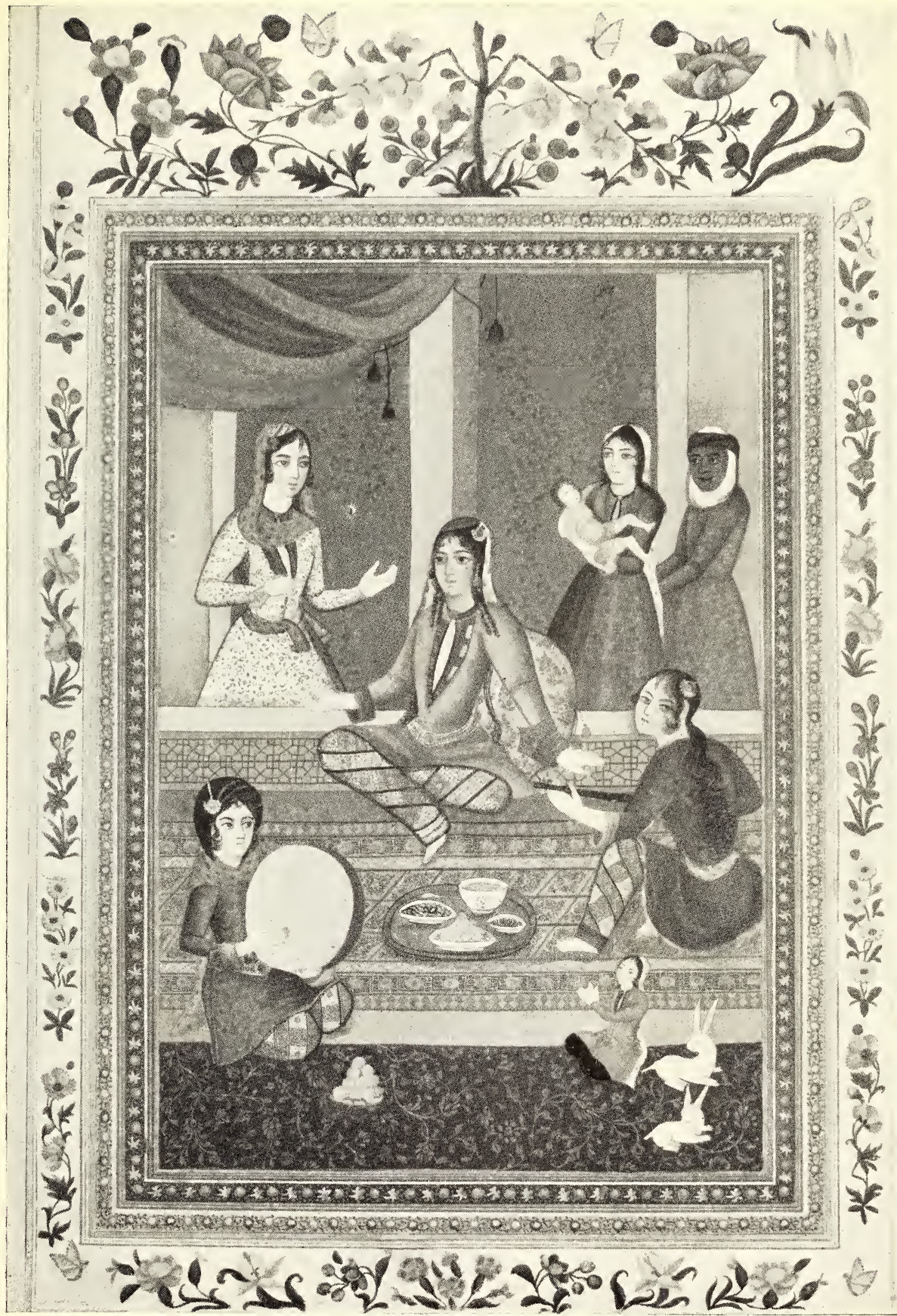

Portrait of Elem Kax Kermani, a celebrated Persian Courtezan, of Shiraz, under the reign of Kerim Kan.

Persia. XVIIIth Century.

See Item No. 262 
Plate C.

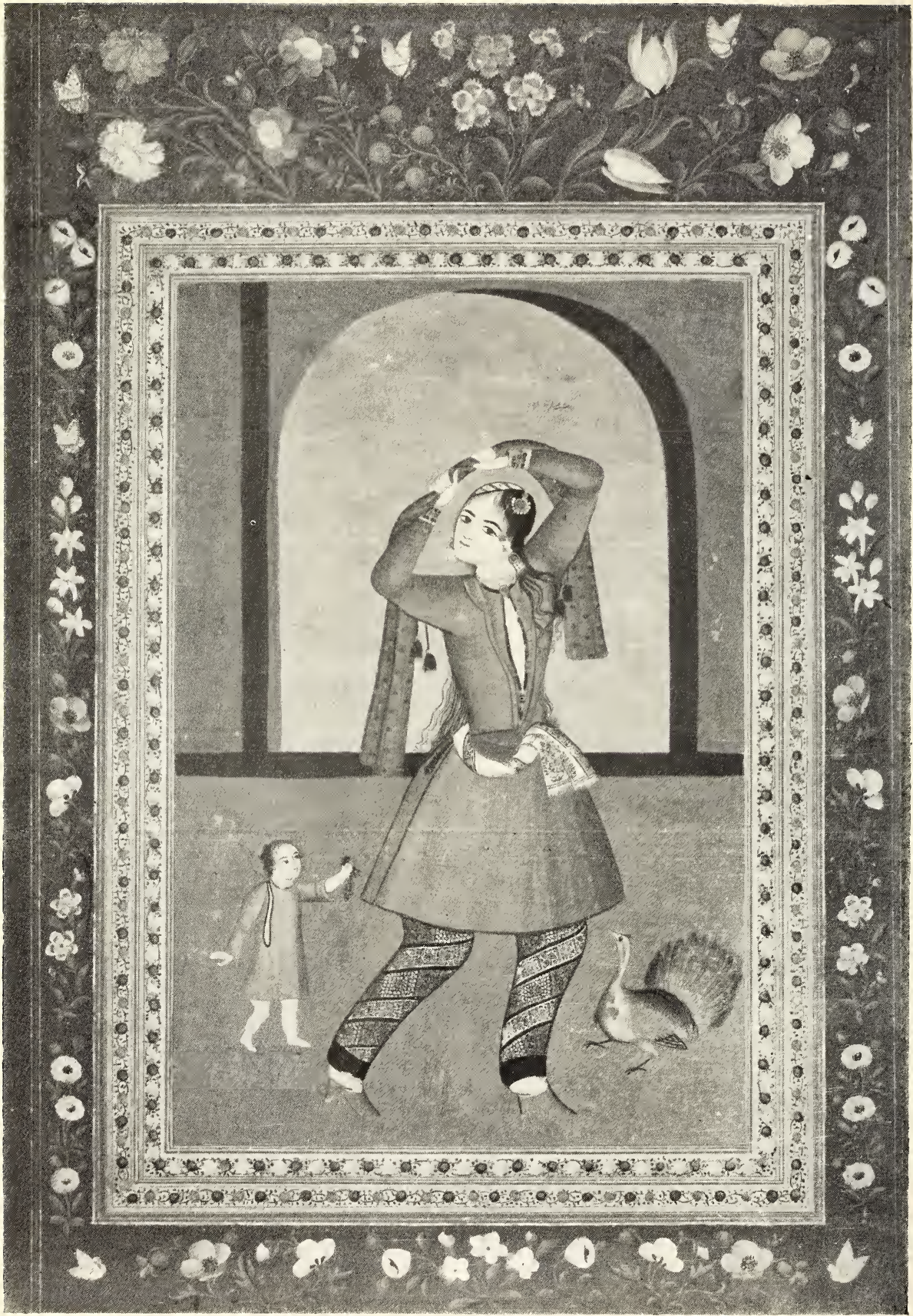

Portrait of Eleu Kax Kensuxi, a celebrated Persian Courtezan, of Shiraz, under the reign of Kerim Kan.

Persia. XVIIIth Century.

See Item No. 264. 


\section{Persian-continued.}

264 A PORTRAIT OF ELEM KAN KERMANI, A CELEBRATED PERSIAN COURTEZAN, OF SHIRAZ, UNDER THE REIGN OF KERIM KAN, WEARING TROUSERS, DANCING ÁND HOLDING A SCARF ABOVE HER HEAD, ON HER RIGH'T SIDE IS A SMALL CHILD AND ON HER LEFT A PEACOCK. SURROUNDED BY A BORDER OF BUTTERFLIES AND FLOWERS, TULIPS, MARIGOLDS, CARNATIONS, ANEMONES, AND OTHER GAILY COLOURED BLOSSOMS.

(MEASURING $12 \frac{3}{4}$ by $9 \frac{3}{4}$ INCHES.)

(Persia, XVIIIth Century.)

(Seee Illustration, Plate No. C.).

$£ 21$

265 SPECIMEN OF PERSIAN CALLIGRAPHY, WITHIN GOLD ORNAMEN'TAL BORDER. (In translation.)

(In smaller characters.)

"O thou master of the age, at this time in the world Greatness is absolutely conferred upon your sacred person."

(In larger characters.)

"Today the world is illuminated by you,

Good fortune and success have become your companions and helpers,

The Blessing for which I used to pray at nights, Hundred thanks (to God) that it has been obtained today! '

Written by

Khairullah.

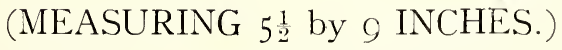

(Persia) XVIIth Century.)

$£ 212$ s $6 \mathrm{~d}$

266 SPECIMEN OF PERSIAN CALLIGRAPHY, WITHIN GOLD ORNAMEN'TAL BORDER.

A CALLIGRAPHIC EXERCISE, TWO LET'TERS OF THE ALPHABET JOINED TOGETHER IN AN ARTISTIC MANNER.

(MEASURING 6 by $6 \frac{7}{8}$ INCHES.)

(Persia. XVIIth Century.) 


\section{Persian-continued.}

\section{PORTRAIT OF THE TURKISH SULTAN HUSSAIN.}

THE PRINCE IS DRESSED IN A RED CLOAK WORN ABOVE A LIGHT GREEN UNDER GARMENT, A WHITE TURBAN IS ON. HIS HEAD. THE BACKGROUND IS GOLD. THE MINIATURE IS MOUNTED WITHIN VERY FINE SPECIMENS OF CALLIGRAPHY BI SULTAN ALI, IN THE PERSIAN STYLE, AND WITHIN A DOUBLE FLOWERED BORDER.

(THE PORTRAIT ITSELF MEASURES 6 by 5 INCHES, WHILE THE WHOLE MEASURES I 6 by I I $\frac{1}{2}$ INCHES).

(Persia. XVIIIth Century.)

(SeE Illustration, Plate No. Ci.) 
Plate CI.

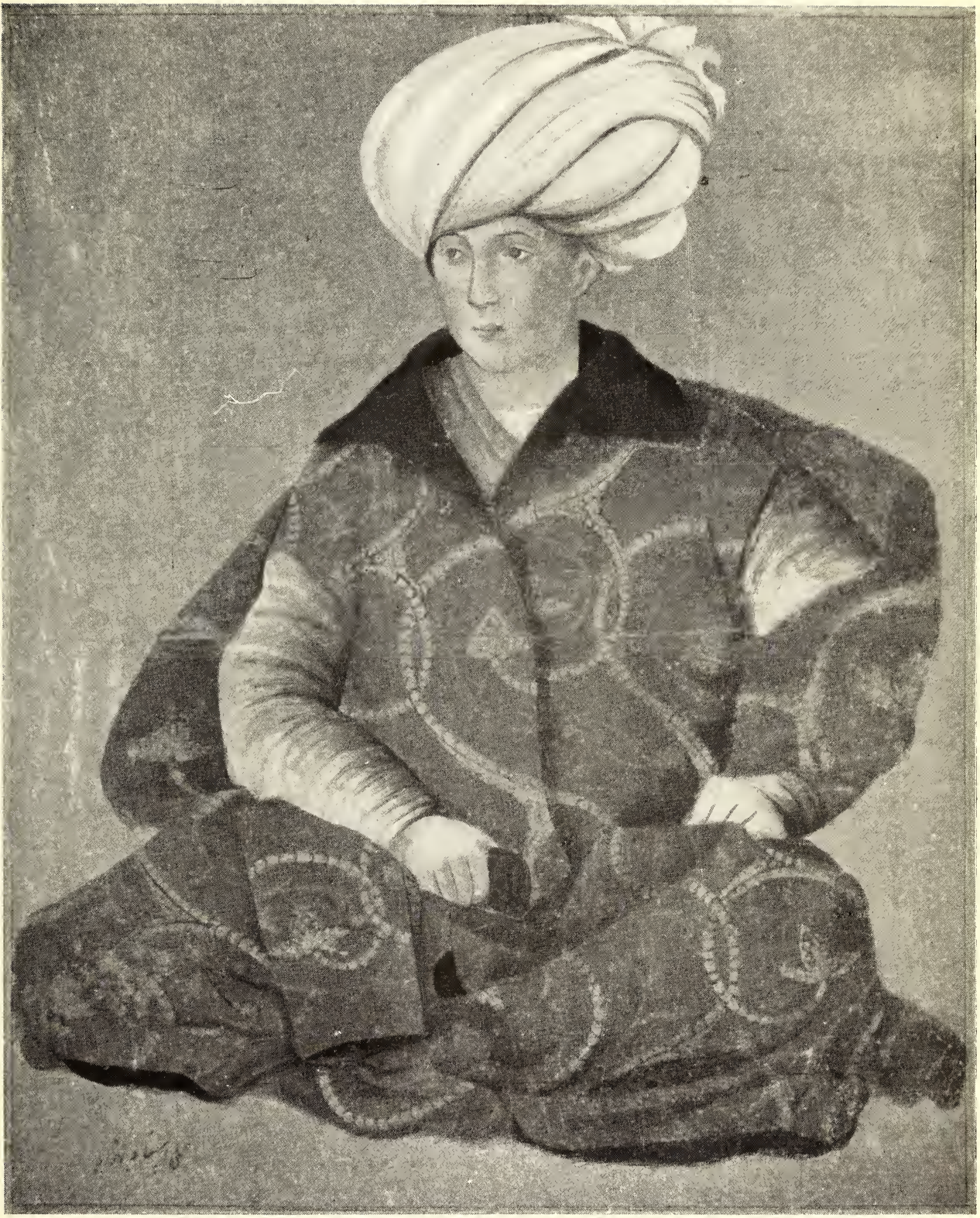

Portrait (equal size) of the 'Turkish Sultax Hussain.

Persia. XVIIIth Century.

See Item No. 267. 


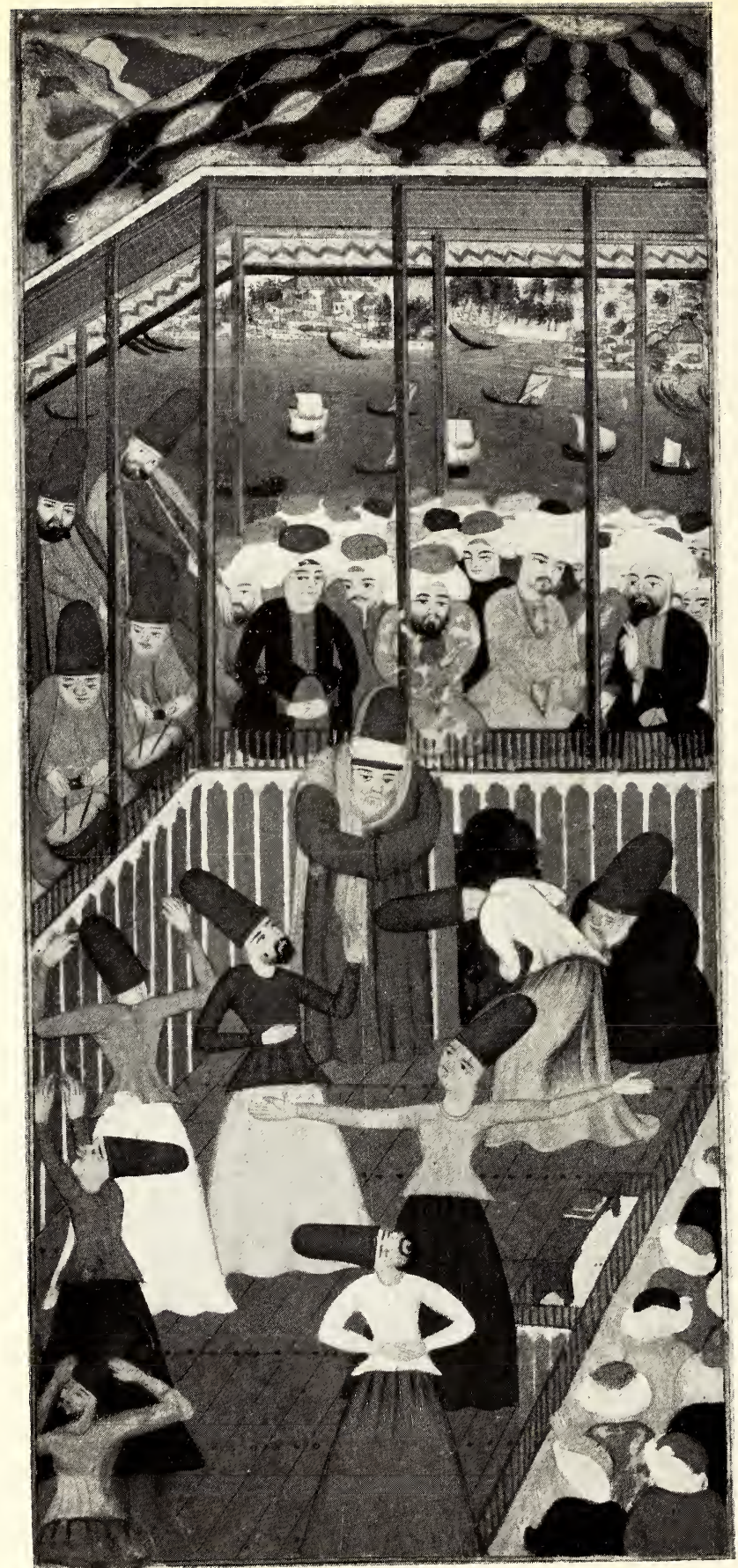

“'The Dancing Dervishes at Constantinople."

The only Miniature known of this scene.

By a Turkish Artist.

Early XVilth Century

See Ttem No. 272. 
MAGGS BROS., 34 \& 35, Conduit Street, London, W.

\section{TURKISH.}

The Only Miniature Known of the Dancing Dervishes.

272 REMĀRKABLE AND BEAUTIFULLY PAINTED MINIATURE ILLUMINATED IN GOLD AND COLOURS, BY A 'TURKISH AR'TIS'T', EARLY XVIITth CEN'TURY, OF 'THE DANCING DERVISHES A'T CONS'TAN'TINOPLE OPPOSI'TE THE GOLDEN HORN.

SEVEN DANCING DERVISHES ARE SHOWN WITH A PECULIAR HEADGEAR WHICH 'THEY S'TILL USE TO-DAY DURING THE RELIGIOUS DANCE, THEY WEAR A COAT AND SKIR'T OF WHITE, GREEN, BLUE OR YELLOW. TO-DAY THEY WEAR WHI'TE ONLY. A BAND IS PERFORMING AND A LARGE CROWD OF GAILY CLO'THED AND TURBANNED SIGH'T-SEERS IS WA'TCHING 'THE PERFORMANCE INTEN'TLY. RIGH'T AT THE BACK CONS'TANTINOPLE AND THE BOSPHORUS COVERED WITH BARQUES IN FULL SAIL ARE VISIBLE.

ON THE REVERSE OF MINIATURE IS A FAMILIAR SCENE IN A TURKISH GARDEN, THE LADY OF THE HOUSE IN ORIEN'I'AL. ATTIRE WI'TH RICH ORNAMEN'TS IS HAVING SUPPER IN THE GARDEN WITH HER SLAVE DRESSED IN BLUE POURING OU'T SHERBET. AN ORCHESTRA OF FOUR LADIES IS PERFORMING; 'THE INSTRUMEN'TS USED ARE A ZI'THER. A MANDOLINE, A TAMBOURINE AND A KIND OF VIOLIN. THE BACKGROUND SHOWS THE MAGNIFICEN'T ORCHARD WITH FRUI'T HANGING FROM THE TREES AND A CHARMINGLY ARRANGED FORMAL GARDEN WITH GAY FLOWERS, THE LILIES BEING IN FULL BLOCM. 'THE LADY IS RECLINING BENEATH A PLUM TREE LADEN WITH FRUIT. ON 'THE RIGH'T A FOUNTAIN IS PLAYING.

(MEASURING io by $4 \frac{3}{4}$ INCHES.)

(Turkey. Early XVIIth Century).

(See Illustration, Plate No. CiI.).

$£ 125$

Religious representations among the Moslems are of exceeding rarity owing to the well-known prohibition against the reproduction of the human figure. Turkish miniatures are especially rare, and no other miniature of this essentially Turkish and essentially religious scene of the Dancing Dervishes is known.

This miniature will be reproduced shortly in Sir Thomas Arnold's fortheoming book on Moslem religion in art.

27.3 CAlligraphy.

FINE SPECIMENS OF TURKISH CALLIGRAPHY SIGNED BY SAYID KHAL NAKIB ZADAH. ON ONE SHEET OF PAPER, IN BLACK AND RED.

(MEASURING i 4 by io INCHES.)

('Turkey. XVIIth Century.) 
232 MAGGS BROS., $34 \& 35$, Condut Street, London, W.

\section{Books on MSS. \& Miniatures.}

\section{EUROPEAN.}

274 ARISTOPHANES. Comedies, facsimile of the Greek manuscript Codex Venetus Marcianus 474, with a preface by J. W. White and an introduction by T. W. Allen.

Folio, haif morocco. London, 1902.

£3 10s

275 BIAGI (G.). Reproductions from illuminated manuscripts. 50 plates from MSS. in the R. Medicean Laurentian Library. With preface and illustrative notes.

Royal 8vo, in portfolio. Florence, I9I4.

$£ 1$ 10s

276 BRUUN (J. A.). An Enquiry into the Art of the Illuminated Manuscripts of the Middle Ages. Part I., Celtic illuminated manuscripts.

With numerous illustrations.

Small folio, original wrappers. Stockholm, I897.

$£ 11 s$

277 BURLINGTON FINE ARTS CLUB. Exhibition of Illuminated Manuscripts. With I62 magnificent plates. 4to, cloth. London, Privately Printed, 1908.

$£ 11$ 11s

278 CHESS. El Tratado de Ajedrez ordenado por mandado del Rey D. Alonso el Sabio en el ano 1283. Codice de la Real Biblioteca del Escorial. Reproduction completa en I94 laminas fototipicas.

2 vols., folio, in cloth portfolios. Leipzig, I9I 3.

$£ 1010$ s.

EXCELLLNT REPRODUCTION OF ONE OF THE FINIST ILLUMINATED MANU. SCRIPTS DEALING WITH CHIESS.

279 COCKERELL (S. C.). A Psalter and Hours executed before i 270 for a Lady connected with St. Louis, probably His Sister Isabelle of France founder of the Abbey of Longchamp, now in the collection of Henry Yates Thompson. Described in relation to the companion Psalter of St. Louis in Paris.

With photogravures of all the miniatures. Oblong 4to, half bound. London, 1905. 
280 COLLECTION OF MINIATURES reproduced from Original Manuscripts of the XIVth and XVth Centuries.

With 72 illustrations in colours and gold.

8vo, half morocco, uncut, $t$. e. $g$. London, N.D.

$18 s$

28 I COMEDIES DE TERENCE. Reproduction des 15 I Dessins du Manuscrit Latin 7899 de La Bibliothèque Nationale.

With 15 I plates.

Thick 4to, boards. Paris, N.D.

$£ 115 s$

282 DELISLE. Facsimilie de livres copiés et enluminés pour le Roi Charles V. 4to, original zurappers. Paris, 1903.

$£ 110$ s

283 Les Grandes Heures de la Reine Anne de Bretagne et L'Atelier de Jean Bourdichon.

With numerous plates of facsimiles.

Folio, in original portfolio. Paris, I9I3.

\&6 6s

Only 250 copies of this book were printed.

284 DELOO (G.). Heures De Milan, troisième partie des Très-Belles Heures de Notre-Dame enluminées par les Peintres de Jean de France, Duc de Berry et par ceux du Duc Guillaume de Bavière Comte du Hainaut et de Hollande. Vingt-huit feuillets historiés reproduits d'après les originaux de la Biblioteca Trivulziana à Milan avec une introduction historique.

With numerous reproductions.

Folio, original portfolio. Brussels, I9I I.

$£ 5$ s

Only 153 copies were issued.

285 DOREZ (L.). Les Manuscrits à Peintures de la Bibliothèque Lord Leicester à Holkham Hall, Norfolk. Choix de Miniatures et de Reliures.

With 6o magnificent plates.

Folio, in original portfolio. Paris, igo8.

$£ 55 s$

286 _ Psautier de Paul III. Reproduction des Peintures et des Initiales du Manuscrit Latin 8880 de La Bibliothèque Nationale. Précedée d'un Essai sur le Peintre et le Copiste du Psautier.

With 33 plates.

Folio, boards. Paris, N.D. 
287. ESCHER (K.). Die Miniaturen in den Basler Bibliotheken Museen und Archiven. colour.

Printed for subscribers, with magnificent reproductions, some in Folio, half morocco. Basel, Igi7.

$£ 12$ 12s

288 EVANGILES avec Peintures Byzantines du Xle Siècle. Reproduction des 36I Miniatures du Manuscrit Grec 74 de La Bibliothèque Nationale.

With 722 plates.

2 vols., 4 to, boards. Paris, N.D.

$£ 2$ 2s

289 FORRER (R.). Unedierte Federzeichunugen, Miniaturen und Initialen des Mittelalters.

With II3 plates, and 3 I illustrations in the text.

2 vols., small folio, cloth. Strassburg, Privately Printed, I90I-I907.

$£ 4$ ss

290 FOUCQUET. Facsimiles of two Histoires by Jean Foucquet from the "Anciennetés des Juifs." With a notice, two photogravures and four three-colour photographs of four detached pages from a manuscript of the XVth century of the "Faits des Romains," as it occurs at the end of some MSS. of the " Histoire ancienne Jusqu'à César.”

With reproductions in colour.

Folio, half bound. London, Privately Printed, Ig03.

£5 5s

29 i GONCALVes MISSEL. Missel Pontifical de Estevam Goncalves Netto, Propriété de L'Academie Royale des Sciences de Lisbonne. Reproduit en Chromolithographie \& precédé d'une notice sur l'ornamentation des MSS. Portugais, avec mention d'un poeme Francais MS. rappelant la fête Brésilienne qui eut lieu à Rouen en I 550 par Ferdinand Denis.

A brilliant reproduction of this splendid manuscript, with 9 fulipage miniatures, and every page surrounded with an elaborate ornamental border, some containing smali miniatures, together with a profusion of Initial Letters.

Royal folio, bound from the original parts, with the wrappers preserved, half morocco, uncut, t. e. g. Paris, I879.

$£ 7$ s

292 GORRINI (G.). L'incendie de la Bibliothèque Nationale de Turin (in French and Italian).

With numerous illustrations of lost and preserved MSS.

8vo, half morocco, gilt, $t$. e. g. Turin, 1905 . 
MAGGS BROS., 34 \& 35, Conduit Street, London, W.

29.3 HEURES D'ANNE DE BRETAGNE. Reproduction Réduite des $\sigma_{3}$ Peintures du Manuscrit Latin 9474 de La Bibliothèque Nationale.

With 63 plates.

4to, boards. Paris, N.D.

$£ 1$ 1s

294 HE URES DITES DE HENRI IV. Reproduction Réduite des 60 Peintures du Manuscrit Latin i I I de La Bibliothèque Nationale.

With 60 plates.

4to, boards. Paris, N.D.

Eit 1s

295 LES HISTOIRES ROMAINES de Jean Mansel Illustrées par Loyset Lyedet. 55 planches reproduisant les miniatures et les encadrements des manuscrits 5087 et 5088 de La Bibliothèque de L'Arsenal.

With 55 plates.

4to, boards. Paris, N.D.

$£ 1$ 1s

296 LABITTE. Les Manuscrits et l'art de les Orner.

With 300 reproductions.

- Royal 8vo, half bound. Paris, I893.

$£ 2$ 2s

297 LABORDE (A. de). Les Manuscripts à Peintures de la Cité de Dieu de Saint Augustin.

With numerous magnifucent reproductions.

3 vols. in 2, folio, original portfolio. Paris, 1909.

$£ 21$

298 La Bible Moralisée Conservée à Oxford, Paris et Londres. Reproduction integrale du manuscrit du XIIIe siècle.

With hundreds of plates.

3 vols., folio, in original portfolios.

Paris, Privately Printed, IgI I-IgI4.

$£ 1616 \mathrm{~s}$

299 LEHNER (F.). Die Böhmische Malerschule des XI. Jahrhunderts I. Das Breslauer Evangeliarium. (Text in German and Bohemian.)

With 32 magnificent plates in gold and colours.

Folio, cloth. Prague, igo2.

$£ 5$

300 LES JOYAUX DE L'ARSENAL. Le Romuleon. 6o Figures en 40 planches reproduisant les miniatures, initiales, etc., du manuscrit 567 de La Bibliothèque De L'Arsenal.

With 40 plates. 4to, boards. Paris, N.D. 
236 MAGgS BROS., 34 \& 35, Conduit Street, London, W.

3OI LIVRE DE LA CHASSE par-Gaston Phébus Comte de Foix. Reproduction réduite des 87 Miniatures du Manuscrit Français 6ı6 de La Bibliothèque Nationale.

$$
\begin{aligned}
& \text { With } 87 \text { plates. } \\
& \text { 4to, boards. Paris, N.D. }
\end{aligned}
$$

302 LIVRe des merveilles marco Polo, Odoric De Pordenone, Mandeville, Hayton, etc. Reproduction des 265 Miniatures du Manuscrit Français 28Io de La Bibliothèque Nationale.

With 530 plates.

2 vols., 4to, boards. Paris, N.D.

£3 3s

30.3 Lovino (G. A.). Traité D'Escrime Dédié au Roi Henri III. Reproduction réduite des 66 miniatures du manuscrit Italien 959 de La Bibliothèque Nationale.

With 66 plates.

4to, boards. Paris, N.D.

$£ 1$ 1s

304 MADDEN (F.). Illuminated ornaments selected from manuscripts and early printed books, from the 6 th to the 17 th centuries.

With numerous reproductions in cclour.

Folio, half morocco. Large paper copy, the plates richly illuminated in gold and colours, t. e. g. London, I833

$\$ 418 \mathrm{~s}$

305 MARTIN (H.). Les Peintres de Manuscrits et la Miniature en France.

With 28 plates.

4to, zerappers. Paris, N.D.

306 MAXIMILIAN I. Freydal, des Kaisers Maximilian I. Turniere und Mummereien Hẹrausgegeben mit Allerhöchster Genehmigung Seiner Majestät des Kaisers Franz Joseph I. unter der leitung des K. K. Oberstkammerers, Feldzeugmeisters Franz Grafen Folliot de Crenneville von Quirin von Leitner.

Illustrated with 255 finely reproduced photogravure plates of Tournaments, Pageants, etc., from the Original Manuscript.

2 vols., folio, half morocco, uncut, t. e. g. Wien, I88o-2.

$£ 21$

307 MAYER (A. L.). Expressionistische Miniaturen des deutschen Mittelalters.

With 32 full-page facsimiles in helio-gravure.

Folio, original wrappers. Munich, Igi8.

$£ 110$ s 
308 MERTON (A.). Die Buchmalerei in St. Gallen vom IXten bis zum XIten Jahrhundert.

With 100 plates of magnifucent early manuscripts.

4to, original portfolio. Leipzig, igi2.

$£ 710$ s

309 MIRACLES DE NOTRE DAME. Reproduction des Miniatures des Mantiscrits Français 9198 et 9199 de La Bibliothèque Nationale.

With i 32 plates.

2 vols., 4to, boards. Paris, N.D.

$£ 1185$

3io NOTITIA DIGNITATUM IMPERII ROMANI. Reproduction Réduite des I05 Miniatures du Manuscrit Latin 966 I de La Bibliothèque Nationale.

With 105 plates.

4to, boards. Paris, N.D.

\&1 5 s

3. I OUTLINES from the Illuminations in the Manuscript Collection of the Songs of the Minnesingers, commonly called The Manesse Manuscript, No. 7266, in the King's Library at Paris, A.D. I 300-I 320.

A unique collection of 89 engravings from the MS. in the Bibliothèque Nationale.

Mounted and bound in small folio volume, half morocco, gilt leaves.

$£ 215 s$

.3 i 2 Peintures et Initiales de la Première and Seconde Bible de Charles Le Chauve. Reproduction du Manuscrit Latin I and 2 de La Bibliothèque Nationale.

With i 7 i plates.

2 vols., 4to, boards. Paris, N.D.

£3 3s

3i.3 PSAUtIER DE SAINT LOUIS et de Blanche de Castille. 50 planches reproduisant les miniatures, initiales, etc., du manuscrit I I 86 de La Bibliothèque Nationale.

With 50 plates.

4to, boards. Paris, N.D.

$18 s$

3i 4 PSAUTIER DE SAINT LOUIS. Reproduction réduite des 92 miniatures du Manuscrit Latin 10525 de La Bibliothèque Nationale.

With 92 plates.

4to, boards. Paris, N.D.

$£ 15 s$ 
3 I 5 PSAUTIER ILLUSTRE (XIIIe Siècle). Reproduction des io7 Miniatures du Manuscrit Latin 8846 de La Bibliothèque Nationale.

With ro7 plates.

4to, boards. Paris, N.D.

$£ 15 s$

3 I 6 SIMONIDES (C.). Fac-similes of certain portions of the Gospel of St. Matthew, and of the Epistles of SS. James and Jude, written on papyrus in the first century, and preserved in the Egyptian Museum of Joseph Mayer, Esq., Liverpool. With the fresco painting at Mount Athos.

Edited and illustrated with notes and historical and literary prolegomena, containing confirmatory fac-similes of the same portions of Holy Scripture from Papyri and parchment MSS. in the Monasteries of Mount Athos, of St. Catherine of Mount Sinai, of St. Sabba in Palestine, and other sources.

With numerous plates.

$4^{\text {to, }}$ original zrappers. London, i 862.

$£ 22 s$

3 I 7 VAN DEN GHEYN (J.). L'Ystoire de Helayne reproduction des 26 miniatures du manuscrit No. 9967 de La Bibliothèque Royale de Belgique. With 26 plates.

Small 4to, boards. Brussels, I9I3.

10s 6d

3 I 8 Christine de Pisan Epitre D'Othéa, Déesse de La Proudence à Hector, Chef des Troyens. Reproduction des 100 miniatures du manuscrit 9392 de Jean Miélot.

With roo plates.

Small 4to, boards. Brussels, I9I3.

$£ 1$

$319 \_$Cronicques et Conquestes De Charlemaine. Reproduction des I 5 miniatures de Jean Le Tavernier, d'Audenarde (1460).

With io5 plates.

Small 4to, boards. Brussels, Igog.

320 _ Deux Livres D'Heures (Nos, io767. et I I05 I De La Bibliothèque Royale de Belgique) Attribués à L'Enlumineur Jacques Coene.

With 5 I plates.

4to, boards. Brussels, N.D.

$16 s$

32 I L Histoire de Charles Martel. Reproduction des IO2 miniatures de Loyset Liédet (1470).

With 102 plates.

4to, boards. Brussels, igro. 
322 VIE ET HISTOIRE DE SAINT DENYS. Reproduction des 30 miniatures du manuscrit Français N. A. Iog 8 de La Bibliothèque Nationale.

With 30 plates.

4to, boards. Paris, N.D.

$10 s 6 d$

323 VOGELSTEIN (J.). Von Französischer Buchmalerei.

With 77 reproductions.

Svo, half bound. Munich, igI4.

f1 $1 \mathrm{~s}$

324 WARNER (Sir George). Queen Mary's Psalter; miniatures and drawings by an English artist of the XIVth century, reproduced from Royal MS.

$2 \mathrm{~B}$.VII in the British Museum.

With numerous magnificent reproductions.

Small folio, half morocco, t. e. g. London, I9I2.

£3 3s

$324 \mathrm{a}-$ Illuminated Manuscripts in the British Museum. Miniatures, borders and initials reproduced in gold and colours.

6o magnificent plates reproduced in gold and colours.

Folio, half morocco, t.e.g. London, I903.

$£ 1414 \mathrm{~s}$

325 Valerius Maximus. Miniatures of the School of Jean Fouquet illustrating the French version by Simon de Hesdin and Nicholas de Gonesse contained in a MS. written about A.D. I475 for Philippe de Comines reproduced in photogravure, with frontispiece in colour for Henry Yates 'Thompson.

With numerous reproductions.

Folio, half bound. London, igo7.

$£ 5$ 5s

326 Descriptive Catalogue of Illuminated Manuscripts in the library of C. W. Dyson Perrins, D.C.L., F.S.A.

With I 28 plates.

2 vols., folio, cloth, t. e. g. Oxford, I920.

$£ 1010 \mathrm{~s}$

327. WESTWOOD (J. O.). Palaeographia sacra pictoria.

Being a series of illustrations of the ancient versions of the Bible, copied from illuminated manuscripts, executed between the IVth and XVIth Centuries.

With numerous plates in colour.

4 to, half morocco, t. e. g. London, i $\$ 45$. 
$240 \quad$ MAGGS BROS., $34 \& 35$, Conduit Street, London, W.

Westwood (J. O.)-continued.

328 Illuminated Illustrations of the Bible, copied from select MSS. of the Middle Ages.

With numerous magnificent reproductions in colour.

$8 \mathrm{vo}$, haif bound. London, I846.

£3 3s

329 ZIMMERMANN. Vorkarolingische miniaturen.

With 367 illustrations.

I vol. text and 4 portfolios of illustrations. 5 vols. in all, cloth.

Berlin, I9I6.

$£ 36$

\section{ORIENTAL.}

\section{Ethiopic Manuscript.}

330 BUDGE (E. A. Wallis). The Lives of Mabâba Seyôn and Gabra Krestos. The Ethiopic Texts, edited, with an English Translation and a Chapter on the Illustrations of Ethiopic MSS., by E. A. W. Budge.

92 coloured plates and 33 illustrations.

Thick 4to, maroon morocco, covered with blind tooling, marbled fore and under edges, t. e. g. London, I898.

$£ 5$ s

THIS REMARKABLE VOLUME IS PRINTED FROM A VELLUM MS. (XVI TO XVIII

CENTURIES) AND CAREFULLY FXECUTED ON THICK VELLUM PAPER, FROM THE ORIGINAL IN LADY MEUX'S COLLECTION; THE COLOURED PLATES, PAINTED EARLY IN THE XVII. CENTURY, ARE REMARKABLE FOR THE VARIETY OF SUBJEC'TS WHICH THEY HELP TO EXPLAIN, AND ARE CAREFULLY REPRODUCED; AND THE BINDING IS A COPY OF THE ORIGINAL.

3.3 I COOMARASWAMY (A.). Rajput painting, being an account of the Hindoo paintings of Rajastan and Panjab Himalayas from the XVIth to the XIXth century, described in their relation to contemporary source with text and translation.

With numerous illustrations, some in colour.

2 vols., folio, cloth. London, igi6.

$£ 2210$ s

\section{GUNZBURG AND STASSOFF. L’Ornament Hébraique.}

With numerous plates magnificently reproduced in gold and colours, text and plates in portfoiio.

Berlin, I905. 


\subsection{HUART (C.). Les Caligraphes et les Miniaturistes de l'Orient Musulman.}

With Io plates, reproductions of Oriental miniatures.

8vo, haif calf, t. e. g. Paris, I908.

$£ 4$ ss

The best French book on Oriental Miniatures and Calligraphy.

334 MACLer. Miniatures Arméniennes. Vies du Christ Peintures Ornamentales (Xe au XVIIe Siècle).

With 68 plates.

Small folio, onginal portfolio binding. Paris, I9I3.

335 MARteau (G.) et VEVER (H.). Miniatures Persanes tirées des Collections de MM. Henry D'Allemagne, Claude Anet, Henri Aubry, Mme. La Csse de Béarn, M. Albert Besnard, Mme. Blair, M. Louis Cartier, MM. Demotte, Jacques Doucet, Ducoté, Mme. Pierre Girod, M. Victor Goloubew, MM. Gulbenkian, etc., et exposées au Musée des Arts Décoratifs Juin-Octobre I9I 2.

With 195 plates of magnificent reproductions, of which a number are in colour.

Two portfolios. Folio. Paris, I9I3.

$£ 84$

Of this magnificent work only 150 copies were printed, through the munificence of M. Doucet.

3.36 MARTIN (F. R.). The miniature painting and painters of Persia, India, and 'Turkey, from the VIIIth to the XVIIIth century.

With numerous plates, some in colours.

2 vols., folio, cloth, t. e.g. London, I9I2.

$£ 35$

3.37 MORITZ (B.). Arabic Palaeography, A Collection of Arabic Texts from the Ist Century of the Hidjra till the year Iooo.

With i 88 plates.

Folio, in original portfolio. Cairo, I905.

$£ 13135$

338 SARRE (F.) und MITTWOCH (E.). Zeichnungen von Riza Abbasi.

With Io illustrations and 48 plates, some in colours.

Royal 8vo, cloth. Munich, IgI4.

$£ 7$ 7s

339 SCHULz (P. W.). Die Persisch-Islamische Miniaturmalerei.

With numerous plates.

2 vols., royal 8vo, cloth. Leipzig, IgI4. 


\section{SHORT LIST OF CONTENTS.}

Aryssinian Minilatures No. 152

Irabic Callifiraphy 153,154

Arabic Languafe (written in) 121-127

Austria (written in) 80,81

Bamberg MS

Belgium (written in) $3,35,59$ Bibles 7, 9, 12, 37, 130, 146

Books on European MSS. 274-329 Books on Orievtal MSS. 330-339

BREVIARY 39

Burmese MSsi. 128,129

(Alligraphy (European) 7,83

Chinese Miniatures 155,156

Chronicles $25,50,60 \mathrm{a}$

England (written in) ... 2, 5a, 6, 11, 12. 13, 14, $15,16,19,20,21,23,24,41,52,59 \mathrm{a}, 62 \mathrm{a}, 64 \mathrm{a}$ Exglish Langtage (written in) .. 20, 23, 59a luropzan Miniatures 89-120

France (written in) ... 4, 5, 7, 8, 18, 22, 25, 27, $30,34,45,50,51 \mathrm{a}, 53,55,56,57,58,60$, $60 \mathrm{a}, 61,78,82,85 \mathrm{a}, 86,88$

French Languge (written in) ..... 5a, 8, 2.5, $45,50,85 \mathrm{a}, 86,88$

(ierman Langiage (written in) 34,83 (iERMany (written in) $1,2 \mathrm{a}, 83$

(rReE LANGUage (written in) 10,37 Jebrew Layglage (written in) ........... 130 Herat Miniatires $157-159$ HoLland (written in) ....................... $56 \mathrm{a}$ Ixdan Mishatres $157-241$ Indan Miniatcres (School unknown) 160-162 Indan Mrnitures (Delhi Schocl) ... 163-166 Indan Miniateres (Indo-Persian School) $168-175$
Ixdian Mixiatcres (Moghul School) .. 168-175 India Miniateres (Rajput School) ... 177-241 Indo-Persiln Miniatures 168-175

Italian Lanceage (written in) $84,84 \mathrm{a}, 84 \mathrm{~b}, 85 \mathrm{~h}$ Iraly (written in) .. 9, 10, 26, 28, 29, 31, 32, $33,36,37,35,39,49,42,43,44,46,47,48,49$, $51,54,57 \mathrm{a}, 58 \mathrm{a}, 58 \mathrm{~b}, 62,63,64,72,73,74$, $75,84,84 a, 84 b, 85 b, s 7$

Korans ....... 121, 122, 123, 124, 125, 126, 126a LaW 24,80

MiAgiC 86,151

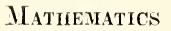
14

MEDICAL $2,59 a, 64 a, 84 a$

Moghul Miniatures $168-175$

MYSTICAL 84

Oriental Miniateres $152-273$

Pali Language (written in) 131

Persian MSs. 132-145

Persian Miniatcres \& Calligraphy ... 241a-267 Psalters $4,5,20,22,58 \mathrm{a}$

REBDORFF MISS. $1 \mathrm{a}, 2 \mathrm{a}$

rioll Velluy Mis. 8,17

Romances of Chivalry 146

SAMaritan Langeage (written in) 147,148 Sanskrit Language (written in) 149,150

Siamese Miniatures 149,150

Siamese Language (written in) 17,85 SPAIN (written in) 17,85

Spanish Languate (written in) 151

Turkisir Langeage (written in) 72,273 


\section{AUTHORS ANI TITLES OF EUROPFAN MSS.}

Aлsto. Costumi e Csanze de Greci ........ 84b

Aretronts. De Milicia ............................. 26

Aristophanes. Plutus \& Clouds (Areek) ... 10

Aristoti.e. De Interpretatione .............. 79

Augusine (St.). Confe-siones ............. 29

Avgustine (St.). Opriscula ................... 36

Argustine (St.). Selmone ................... 2a

Biblia GrRaEca ................................ 37

Biblia Latina ............................... $\quad$, 9, 12

Breviarium Herenitartal $\mathrm{S}$. Axtonil ........ 39

Burley (Walter de). De Phiiosophorum

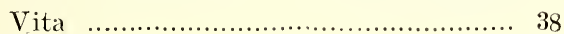

CALLI\%RAPHY

Casa de Nobili Venetiani ...................... $85 \mathrm{~b}$

Castrucci, Arte Della Medicina .............. 84a

Chiromancy ...................................... $88_{\mathrm{a}}$

Chrysostomus. Homilies ................... 13

Сıсъло. De Officiis .................... 40, 12, 14

Cicero. De Senectute ............................ 41

Cicero. De Amicitia ........................... 47

Cicero. Tusculanae Quaestiones ........... 43

Cicero. Orationes Philippicale ................ 3Т

Coliectanea f................................. 11, 16

Cordial (Le) ..................................... 45

Dionysius. De Celesti Hierarchia .......... 46

Dodeci Divotioni ................................. 84

Euclid. Fifteen Books of Elements (Latin) 14

Eusebius. De Erangelica Praeparatione 48

Eutropiss. De Gestis Romanorum ........ 49

Executoria .......................................... 85

Festivale \& Dominicale ....................... 1a

Frotssart. Les Chroniques .................. 50

Gazophilaciuni .................................... 21

Geneliogy of Jests from dohit .................. 6

Graduale ......................................... 81

Henry of Kyaresboroggh. Collectanea ... 11

IJorace. Opera ................................. 51

Horae Beatae Mariae Vmginis ... 18, 19, 27, 51a, 52, 53, 54, 5. , 56, 57, 58, 59, 60, 61
Jerome (ST.). Fipistolae ....................... 62

Jerolif (St.). Très Saincte Vie, Mort,

Miracles .............................. 73

Jerome (St.). Tractatus in Matthaeum ... 1

JeROME (St.). Vita et Obitus ................. 63

Lactintius. Adversus qentiles ..............64

Le Bret. Chronicle of England ............ 5a

Lino. Dialogi .................................. 33

Taurence. Book of Vices and Virtues ... 23

Laurexce. Livre des Vices et Tirtu-... 62a

Lorris. Roman de la Rose .................... 8

Matutinale Praemonstratense ................. 35

Medicinae T'ractatus ............................. 2

Medical Recipes ......................... 59a, $64 \mathrm{a}$

Nicolas de Lyra. Postilia ................... 61a

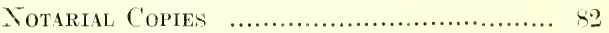

Ovid. Fasti ..................................... 32

PASSIO JESU N.................................. $56 \mathrm{a}$

Persius. Satires ................................. 51

Peter V. Chronicle of Simon de Montfort 60a Perrus de Riga. Aurora .................. $\zeta, 9$

Prubentils. Cathemerinon ................... 3

Psalter (English) ............................ 20

Psalterium (Tatin) ................. 4, 5, 22, 58a

Recueil de Poesies ................................. $8 \&$

Reformations Ordnuxg Boemmens .............. 80

Ritus Admittend Virgines ..................... 87

Romax dF la Rose n........................... 8

Saint Denis. Cérémonies pour réception 8.5a

Sant George. Vida del Cavaller Sant

Jordi ....................................... 17

SEdulits. Paschale Carmen ................... 28

SExeca. Tragedies (in Latin) ............. $58 b$

SERMONES ........................................... 15

Sinon de Montrort. Chronicle (in Latin) 60a

Solomon (King). Clavicule magiqne ..... 86

Statius. Thebaid ............................... 51

Stateta Angliae ................................. 24

Suetonius. Vitae duodecim Caesarum ... 72

Thomas a Kemprs. Imiatio Christi (German) ..................................... 34

Thomas a Kenpis. Imitatio Christi (Latin) 30 
ACTHORS AND TITLES OF EUROPEAN MSS.-continued.

Valerius Maxinus. Les faits \& dits des Romains 25

VIRGIL. Aeneid $73,74,75$

Virgil. Bucolica \& Georgica ........ 51, 57a

VIRGIL. Georgica

\section{AUTHORS AND TITLES OF ORIENTAL MSS.}

Al-HARIRI. The Nakamat 127

Amr-Khtsrau. Khirad Nameir ........... 132 BHAG.AVAD-Gita ......................... 147, 148

Buddhist Scrip'i ures ......................... 131

Collection of Persian Prayers .............. 143

D) IWAX of HAFIZ .............................. 139

Diwax of Salian-SaWaJI 133

Esther (Book of, in Hebrew) ............. 130

Farid-Ul-din Attar. Mantik-Ul-Tair ... 145

Firdusi. Shah-Nameh .......... 136, 137, 141

Gulistax ....................................... 140

Hafiz. DiWAX .................................... 139

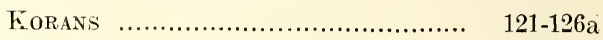

Lives of the Kings of Persia ............. 142

MaariJ-Al-Nebuvvat ............................. 144

MANTIK-LL-TAIR ................................ 145

Mohammad-Assar. Mihir-ul-Mughtari ... 134a

Nizani. Khamsah ...................... 134, 138

Persian Poems ........................................ 135

Phra Malai ........................................ 149

Phrom Maxa ......................................... 150

SAd. Gulistan .................................. 140

Salaian Sawaji. Diwan .......................... 133

ShaH-N AMEH ............................. 136, 137, 141

Turkish Astrologi ............................... 151 


\section{CURRENT CATALOGUES.}

(Mostly Illustruted).

Cat. No. 379.-Early English Literature before 1700

689 Items

382.-English Literature, 18th Century ..

516,

387.---Aeronautical Books and Engravings

1,491,

$1,222 \quad \ldots$

390.-First Editions, Association Books, etc., Part 1I. : L-Z. ..

1,263

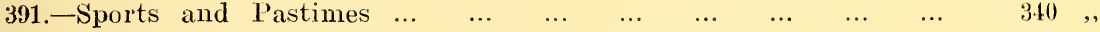

392.-Engraved Portraits and Decorative Subjecis. ... $\quad \ldots \quad \ldots \quad \ldots \quad \ldots \quad$... 668 ,

393. - French Literature and Armorial Bindings $\ldots \ldots$. $\ldots \quad \ldots \quad \ldots \quad \ldots \quad$,

395.-Illuminated Manuscripts, Incunables, Woodeut Books, etc. ... 1,474,,

396.-Autograph Letters and MSS. (Antumn, 1920) $\ldots$... $\quad \ldots \quad$. 848 ,

397.-Rare and Beautiful Books, Manuscripts and Binding's ... ... 3S5 ,,

39S.-Engraved l'ortraits, Decorative Subjects, Etchings, etc. ... ... 712 ,

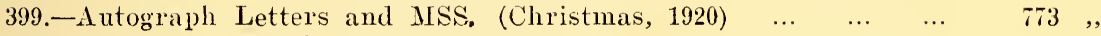

400.-Standard Authors, Library Sets, etc. $\ldots \quad \ldots \quad \ldots \quad \ldots \quad \ldots \quad \ldots \quad \ldots \quad 1626$,

401.-Autograph Letters, MSS., tte. of American Interest (Sirring, 1921) 599 ,,

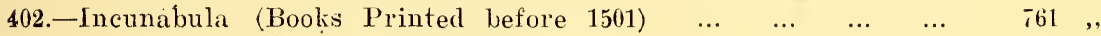

403.-America and the East (Early Geographies, etc.) .. $\ldots \quad$... 532 ,

404.- - Illuminated Manuscripts and Miniatures (European and Oriental) 339,,

405.-Autograph Letters and MSS. (Summer, 1921) $\ldots$... $\quad \ldots \quad$ \&31 ,

In the Press-

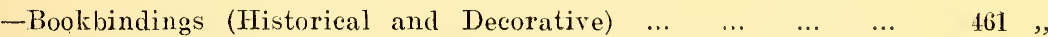

-Books oll the Fine Arts

-Engraved Portraits

-Association Books

*** All the Catalogues enumerated above are current and quite distinct trom each other; they represent only a small part of our very large stock of Fine and liare liookn, P'rints, and Autographs.

Customers' "Wants" searched for and reported free of charge.

Orders through an Agent should be duplicated direct, thus ensuring same receivmg immediate attention.

Clients having no further use for this Catalogue would greatly oblige by passing it on to some friend likely to be interested. 


\section{SMITHSONIAN INSTITUTION LIBRARIES
S \\ 39088015798724 \\ Illuminated MZanuscripts \\ and IIziniatures}

No. 404

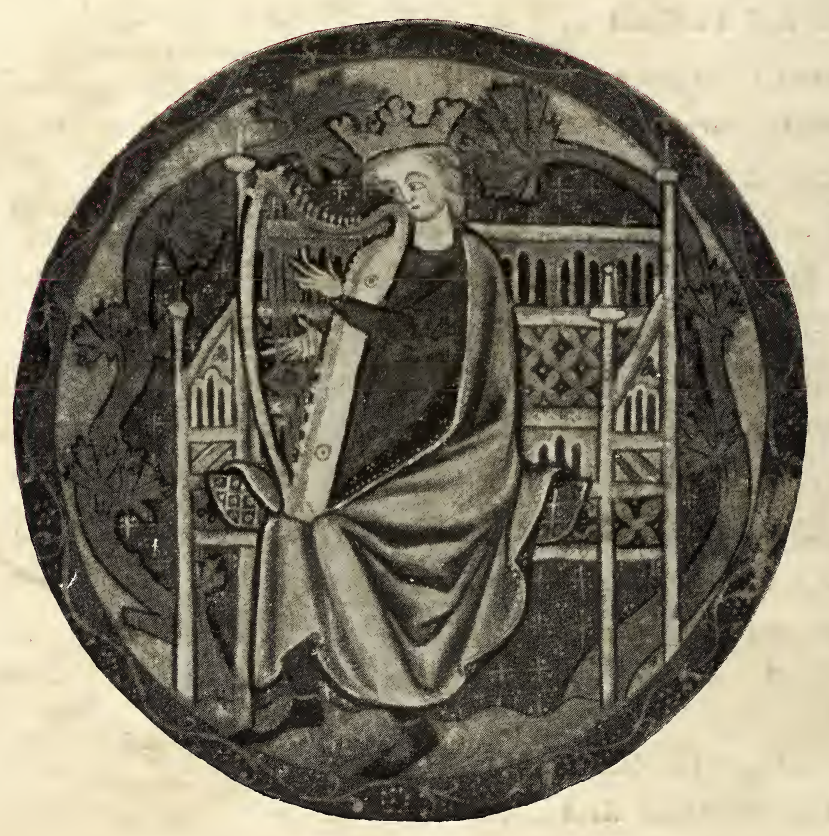

\section{Ilzagas Bros.}

34 \& 35, Conduit Street, Rew Bond Street, Condon, W. 